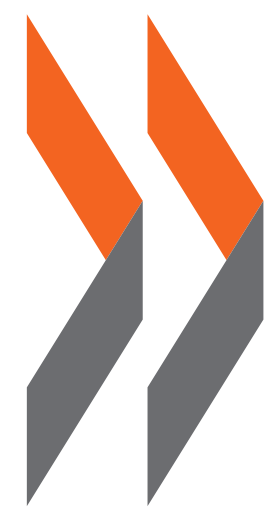

\title{
Building a High-Quality Teaching Profession LESSONS FROM AROUND THE WORLD
}

Andreas Schleicher
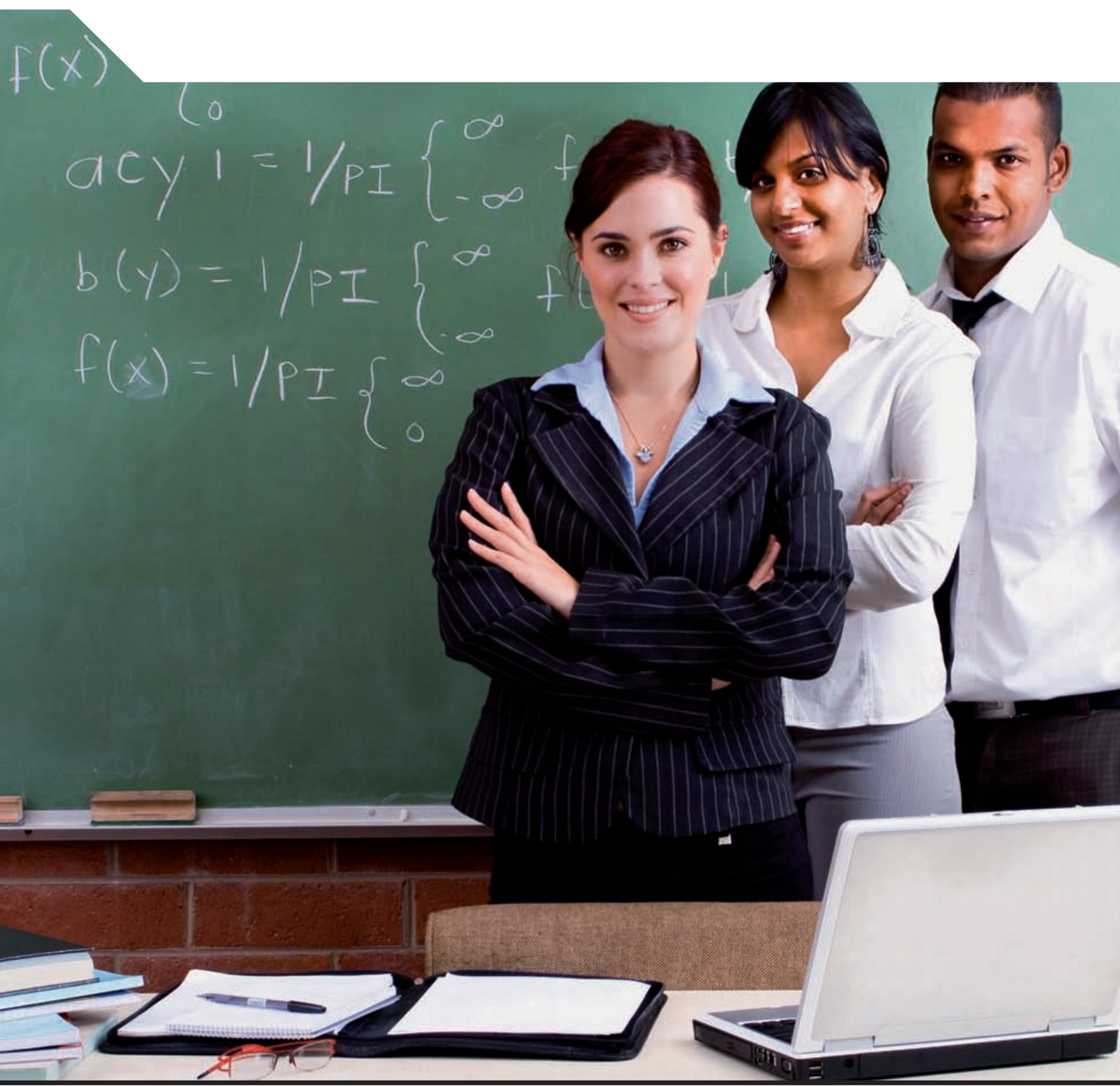

Background Report for the International Summit on the Teaching Profession

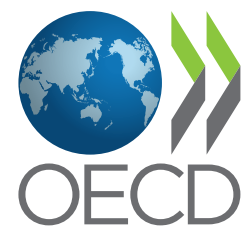





\section{Building a High-Quality Teaching Profession}

LESSONS FROM AROUND THE WORLD 
This work is published on the responsibility of the Secretary-General of the OECD. The opinions expressed and arguments employed herein do not necessarily reflect the official views of the Organisation or of the governments of its member countries.

This document and any map included herein are without prejudice to the status of or sovereignty over any territory, to the delimitation of international frontiers and boundaries and to the name of any territory, city or area.

\section{Please cite this publication as:}

Schleicher, A. (2011), Building a High-Quality Teaching Profession: Lessons from around the World, OECD Publishing.

http://dx.doi.org/10.1787/9789264113046-en

ISBN 978-92-64-09843-5 (print)

ISBN 978-92-64-11304-6 (PDF)

\section{Photo credits:}

Stocklib Image Bank @ HONGQI ZHANG.

Corrigenda to OECD publications may be found on line at: www.oecd.org/publishing/corrigenda.

(c) OECD 2011

You can copy, download or print OECD content for your own use, and you can include excerpts from OECD publications, databases and multimedia products in your own documents, presentations, blogs, websites and teaching materials, provided that suitable acknowledgement of OECD as source and copyright owner is given. All requests for public or commercial use and translation rights should be submitted to rights@oecd.org. Requests for permission to photocopy portions of this material for public or commercial use shall be addressed directly to the Copyright Clearance Center (CCC) at info@copyright.com or the Centre français d'exploitation du droit de copie (CFC) at contact@cfcopies.com. 


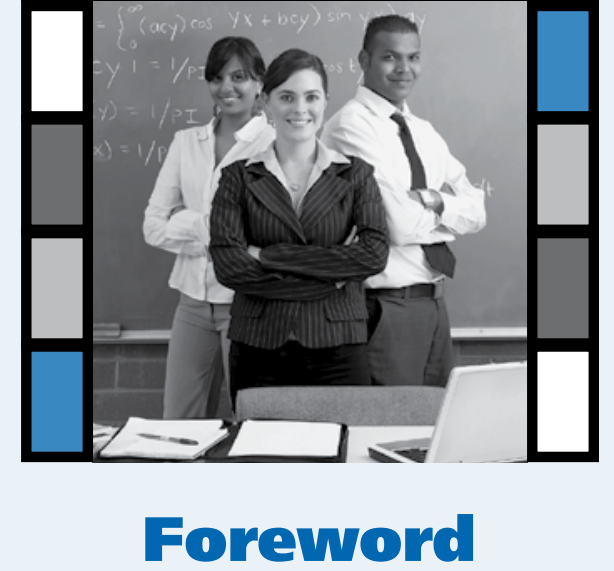

Teachers and school leaders are being challenged to transform educational outcomes, often under difficult conditions. They are being asked to equip students with the competencies they need to become active citizens and workers in the 21 st century. They need to personalize learning experiences to ensure that every student has a chance to succeed and to deal with increasing cultural diversity in their classrooms and differences in learning styles. They also need to keep up with innovations in curricula, pedagogy and the development of digital resources.

The challenge is to equip all teachers, and not just some, for effective learning in the 21 st century. This will require rethinking of many aspects, including: how to optimize the pool of individuals from which teacher candidates are drawn; recruiting systems and the ways in which staff are selected; the kind of initial education recruits obtain before they start teaching, how they are monitored and inducted into their service, and the continuing education and support they get; how their compensation is structured; and how the performance of struggling teachers is improved and the best performing teachers are given opportunities to acquire more status and responsibility.

Recognizing that addressing these challenges requires teachers not just to improve educational outcomes in classrooms, but to be at the centre of the improvement efforts themselves and to embrace and lead reform, the U.S. Department of Education, the OECD and Education International brought education ministers, union leaders and other teacher leaders together in the first International Summit on the Teaching Profession in March 2011 in order to explore effective policy responses.

This publication summarizes the evidence that underpinned the Summit and reflects on the lessons that have been learned. It looks at system features that shape successful teacher careers and work environments as well as at the processes that can make educational reform effective. While some issues around effective teacher policies continue to be discussed controversially, the Summit participants agreed that significant improvement is possible. Contrary to what is often assumed, a high-quality teaching force is not due simply to a traditional cultural respect for teachers but is a result of deliberate policy choices, carefully implemented over time. The many examples of reforms in this publication that have produced specific results, show promise or illustrate imaginative ways of implementing change, show how the challenges have been addressed.

The publication was drafted by Andreas Schleicher, in consultation with the Summit co-sponsors - the U.S. Department of Education, Education International, the National Education Association, the American Federation of Teachers, the Council of Chief State School Officers, the Asia Society and the New York Public Television station WNET based on the OECD Programme for International Student Assessment (PISA) reports; ${ }^{1}$ the OECD Teaching and Learning International Survey (TALIS); ${ }^{2}$ the OECD's comparative policy review Teachers Matter ${ }^{3}$ the reports of the ILO/UNESCO Committee of Experts on the Application of the Recommendations concerning Teaching Personnel; the OECD's annual data collection Education at a Glance; the OECD's report Strong Performers and Successful Reformers; ${ }^{4}$ the OECD's review of Evaluation and Assessment Frameworks for Improving School Outcomes; ${ }^{5}$ the OECD's study Evaluating and Rewarding the Quality of Teachers - International Practices; ${ }^{6}$ the OECD's report Making Reform Happen; ${ }^{7}$ and the outcomes from the recent meeting of OECD Education Ministers in November 2010.

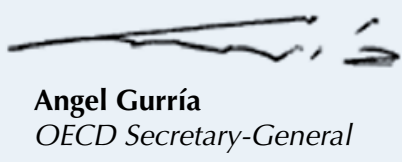





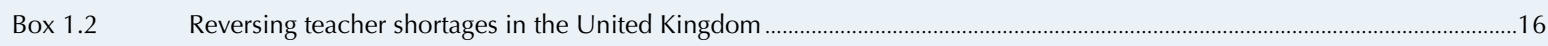

Box $1.3 \quad$ Teachers and schools take on responsibility for reform in Finland …….................................................................................17

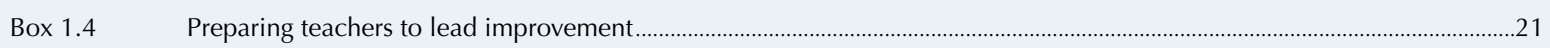

Box $2.1 \quad$ Innovative teacher-preparation programs in the United States ...................................................................................................27

Box 2.2 Providing greater career diversity in Australia, England and Wales, Ireland and Quebec (Canada) .......................................36

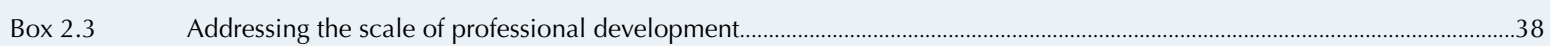

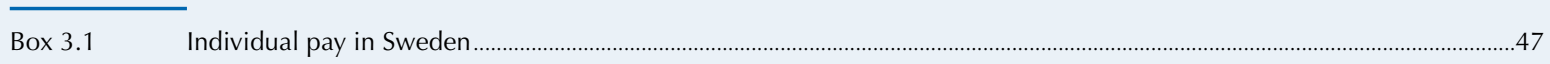

Box 3.2 Identifying and certifying outstanding teachers ...........................................................................................................

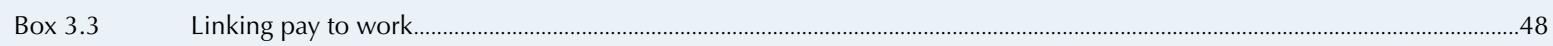

Box 3.4 A comprehensive approach to teacher appraisal and compensation in Singapore ............................................................52

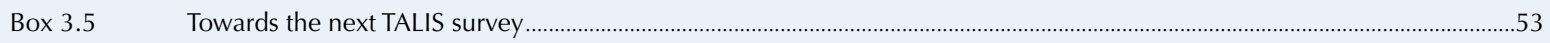

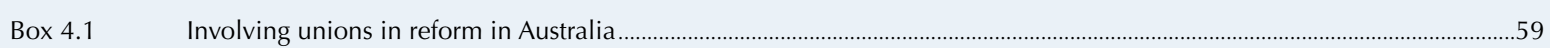

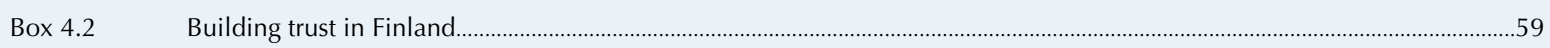

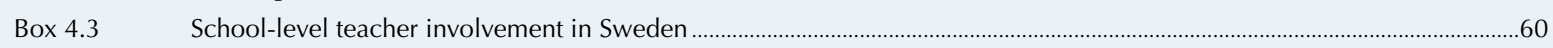

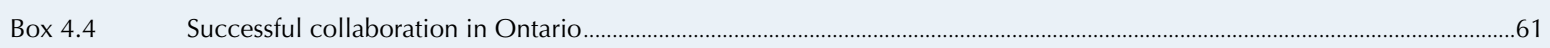

Box 4.5 Transforming government-union relations in the United States ..............................................................................................62

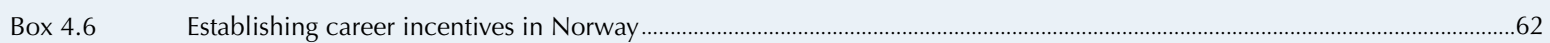

\section{FIGURES}

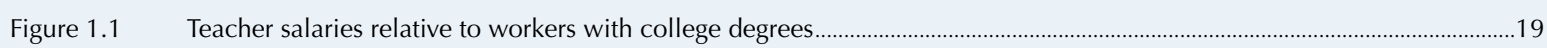

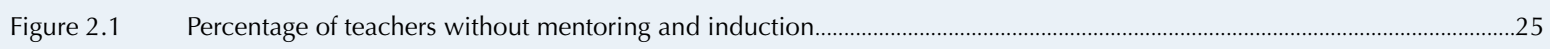

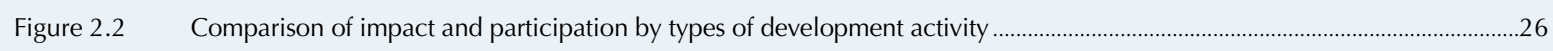

Figure 2.3 Reasons for not taking more professional development...................................................................................................................26

Figure 2.4 Areas of greatest need for teacher professional development............................................................................................2

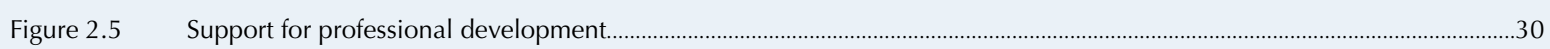

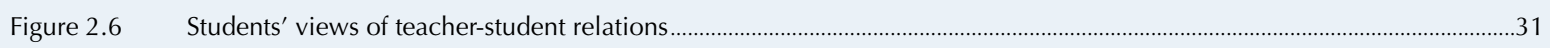

Figure 2.7 How much autonomy individual schools have over resource allocation ...................................................................................

Figure $3.1 \quad$ Percentage of teachers without appraisal in the last 18 months ................................................................................................ 41

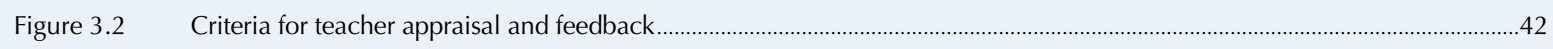

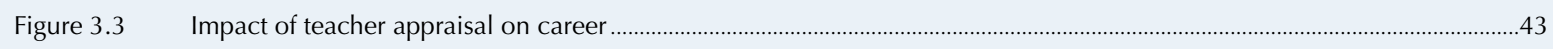

Figure $3.4 \quad$ Consequences of teacher performance as reported by teachers ……........................................................................................ 44

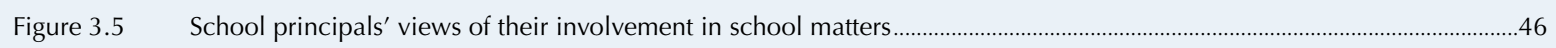

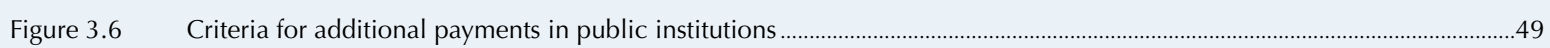

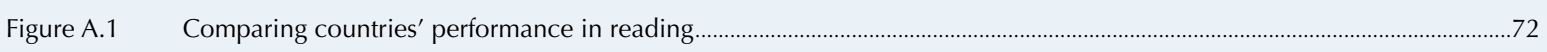

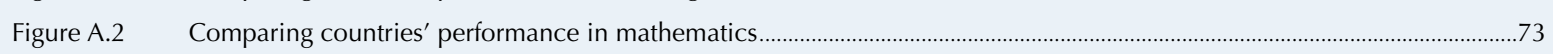

Figure A.3 Comparing countries' performance in science _................................................................................................................

Figure A.4 Relationship between school average socio-economic background and school resources .........................................................75

Figure A.5 School principals' views of how teacher behaviour affects students' learning ...........................................................................

Figure A.6 School principals' views of their involvement in school matters ..........................................................................................77

Figure A.7 Selected characteristics of school systems with reading performance above the OECD average …………….........................78

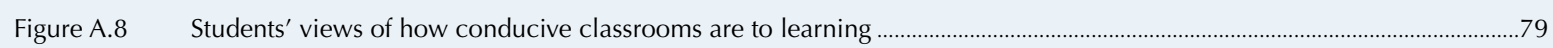

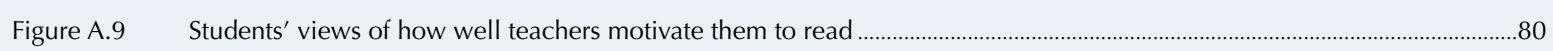

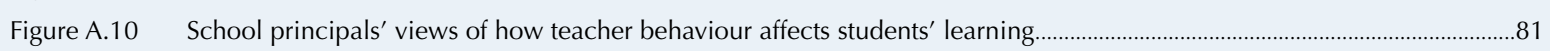

Figure A.11 How much autonomy individual schools have over resource allocation ...................................................................................... 82

Figure A.12 How much autonomy individual schools have over curricula and assessments ......................................................................... 
TABLES

Table A. 1

Average class size, by type of institution and level of education (2008)

Table A.2

Ratio of students to teaching staff in educational institutions (2008).

Table A.3

Teachers' salaries (2008)...

Table A.4

Organization of teachers' working time (2008)...

Table A.5

Number of teaching hours per year $(1996,2008)$

Table A.6

Participation of teachers in professional development in the previous 18 months (2007-08).

Table A.7

Amount of professional development undertaken by teachers in the previous 18 months (2007-08) teacher characteristics

Table A.8

Amount of professional development undertaken by teachers in the previous 18 months (2007-08) school characteristics

Table A.9

Types of professional development undertaken by teachers (2007-08).

Table A.10

Teachers who wanted to participate in more development than they did in the previous 18 months (2007-08)

Teachers' high professional development needs (2007-08). 

A great challenge for educators is that the things that are easiest to teach and test, are also the things easiest to digitize, automate and outsource.

These changes have profound implications for teachers, teaching and learning, requiring a shift from delivered wisdom to user-generated wisdom..

...from standardization and conformity towards personalized educational experiences, and...

...from schools organized like assembly lines towards a work organization that supports high-level knowledge workers.

Many aspects of teacher policies need to be reconsidered.
Many countries have seen rapidly rising numbers of people with higher qualifications. But in a fast-changing world, producing more of the same education will not suffice to address the challenges of the future. Perhaps the most challenging dilemma for teachers today is that routine cognitive skills, the skills that are easiest to teach and easiest to test, are also the skills that are easiest to digitize, automate and outsource. A generation ago, teachers could expect that what they taught would last for a lifetime of their students. Today, where individuals can access content on Google, where routine cognitive skills are being digitized or outsourced, and where jobs are changing rapidly, education systems need to place much greater emphasis on enabling individuals to become lifelong learners, to manage complex ways of thinking and complex ways of working that computers cannot take over easily. Students need to be capable not only of constantly adapting but also of constantly learning and growing, of positioning themselves and repositioning themselves in a fast changing world.

These changes have profound implications for teachers, teaching and learning. In the past, the policy focus was on the provision of education, today it is on outcomes, shifting from looking upwards in the bureaucracy towards looking outwards to the next teacher, the next school. The past was about delivered wisdom, the challenge now is to foster user-generated wisdom among teachers in the frontline. In the past, teachers were often left alone in classrooms with significant prescription what to teach. The most advanced education systems now set ambitious goals for students and are clear about what students should be able to do, and then prepare their teachers and provide them with the tools to establish what content and instruction they need to provide to their individual students.

In the past, different students were taught in similar ways, today teachers are expected to embrace diversity with differentiated pedagogical practices. The goal of the past was standardization and conformity, today it is about being ingenious, about personalizing educational experiences; the past was curriculum-centered, the present is learner centered. Teachers are being asked to personalize learning experiences to ensure that every student has a chance to succeed and to deal with increasing cultural diversity in their classrooms and differences in learning styles, taking learning to the learner in ways that allow individuals to learn in the ways that are most conducive to their progress.

The kind of teaching needed today requires teachers to be high-level knowledge workers who constantly advance their own professional knowledge as well as that of their profession. But people who see themselves as knowledge workers are not attracted by schools organized like an assembly line, with teachers working as interchangeable widgets in a bureaucratic command-and-control environment. To attract and develop knowledge workers, education systems need to transform the work organization of their schools to an environment in which professional norms of management complement bureaucratic and administrative forms of control, with the status, pay, professional autonomy, and the highquality education that go with professional work, and with effective systems of teacher evaluation, with differentiated career paths and career diversity for teachers.

All this requires rethinking of many aspects of teacher policies, including: how to optimize the pool of individuals from which teacher candidates are drawn; recruiting systems and the ways in which staff are selected; the kind of initial education recruits obtain before they start their job and how they are monitored and inducted into their service and the continuing education and support they get; how their compensation is structured; and how the performance of struggling teachers is improved and the best performing teachers are given opportunities to acquire more status and responsibility. In short, just as the quality of an education system cannot exceed the quality of its teachers, the quality of teaching and teachers cannot exceed the quality of the work organization in which teachers find themselves, the quality of teacher selection and education, the quality of teacher careers and the quality of teacher evaluation. 


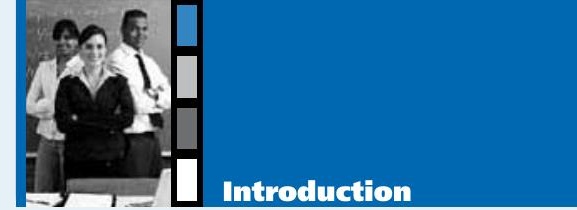

Results from the OECD's Programme for International Student Assessment (PISA) have shown that the degree to which education systems succeed in equipping students with important foundation skills varies significantly (for data see Annex A).

Since the quality of teaching is at the heart of the observed student learning outcomes, it was an appealing idea to bring together education leaders from high performing and rapidly improving education systems to explore to what extent educational success and some of the policies related to success transcend the specific characteristics of cultures and countries.

To this end, in March 2011 the first International Summit on the Teaching Profession was held in New York, hosted by the U.S. Department of Education, the OECD and Education International. The Summit brought together education ministers, union leaders and other teacher leaders from high-performing and rapidly improving education systems ${ }^{8}$ to review how best to improve teacher quality and the quality of teaching and learning.

The pre-Summit version of this publication underpinned the Summit with available evidence about what can make teacher-oriented reforms effective, and highlighted examples of reforms that have produced specific results, show promise or illustrate imaginative ways of implementing change.

The Summit was organised around four interconnected themes. Of the four themes, the first three looked at system features that shape particular aspects of teachers' professional careers. The fourth theme looked at process, and considered what can make reform effective. Specifically, the post-Summit publication considers:

1. How teachers are recruited into the profession and trained initially. In face of widespread shortages that, in many countries, will soon grow as large cohorts retire, intelligent incentive structures are needed to attract qualified graduates into the teaching force. Pay levels can be part of this equation. However, countries that have succeeded in making teaching an attractive profession have often done so not just through pay, but by raising the status of teaching, offering real career prospects, and giving teachers responsibility as professionals and leaders of reform. This requires teacher education that helps teachers to become innovators and researchers in education, not just deliverers of the curriculum.

2. How teachers are developed in service and supported. Surveys show large variations across and within countries in the extent of professional development. Not only the quantity but also the nature of this activity is critical. Often, the professional development of teachers is disjointed in one-off courses, while teachers interviewed for the Teaching and Learning International Survey (TALIS) reported that the most effective development is through longer programs that upgrade their qualifications or involve collaborative research into improving teaching effectiveness. TALIS also shows that in expanding opportunities, teachers have often played a significant role in sharing the cost of development: those who did have tended to get more out of it, as did those who make development a collaborative activity, working together with colleagues to improve practices. A further issue related to supporting teachers in service is the extent to which their conditions of employment and their career prospects can be adapted to meet their needs and aspirations.

3. How teachers are evaluated and compensated. Results from TALIS show that, at its best, appraisal and feedback is supportive in a way that is welcomed by teachers. It can also help lead to self-improvement and be part of efforts to involve teachers in improving schools. At present, most teachers do not feel that school leaders use appraisal to recognize good performance, which suggests that a key component of appraisal is appropriate training for those conducting the appraisals. A connected issue, which also requires sensitive handling, is the criteria used to link rewards with performance. Whatever system is used must be fair, based on multiple measures, and transparently applied in ways that involve the teaching profession.

The first International Summit on the Teaching Profession brought together education ministers, union leaders and other teacher leaders from high-performing and rapidly improving education systems...

...and this publication brings together available evidence underpinning the Summit. 
4. How teachers are engaged in reform. Fundamental changes to the status quo can cause uncertainties that trigger resistance from stakeholders; and without the active and willing engagement of teachers, most educational reforms fail. The chances for success in reform can improve through effective consultation, through a willingness to compromise and, above all, through the involvement of teachers in the planning and implementation of reform. In moving beyond consultation to involvement, the reform process becomes oriented towards transforming schools into learning organizations, with teaching professionals in the lead.

The chapters in this publication and the issues they deal with should not be considered in isolation. In fact, their interdependence is key to understanding the nature of the policy and implementation challenges. For example, simply raising entrance standards for teachers will choke off the supply of teachers unless compensation and working conditions are aligned. Raising pay and changing working conditions alone will not automatically translate into improvements in teacher quality unless standards are raised. Teacher evaluation systems will have limited impact if they only relate to compensation but not professional development and career advancement. Giving teachers more autonomy can be counterproductive if the quality and education of the teachers are inadequate. Not surprisingly, therefore, one of the main conclusions of the Summit was that in order to succeed, teacher policies cannot just tackle one small piece of the puzzle at a time but must be part of a comprehensive approach. ${ }^{9}$ 


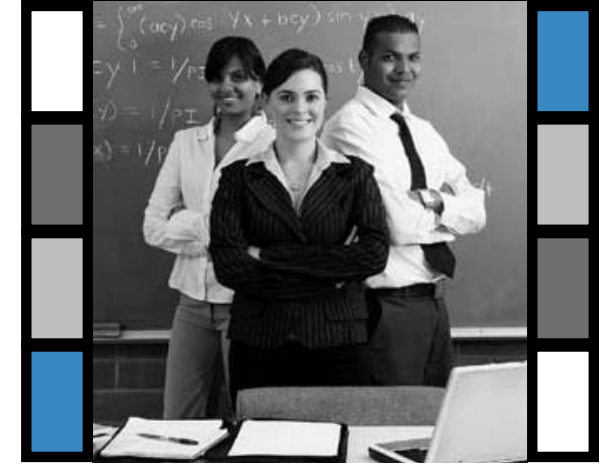

Chapter 1

\section{RECRUITMENT AND INITIAL PREPARATION OF TEACHERS}

Education systems face a demanding challenge in recruiting high-quality graduates as teachers, particularly in shortage areas. At the Summit, Brazil and China reported how they are wrestling with getting good teachers into their vast rural areas; Japan and several other countries reported on planning for large-scale imminent retirements; the United States expressed concerns about high attrition rates, with teachers simply leaving the profession; the Netherlands reported on how decisions on class-size reductions had increased the demand for teachers and Belgium noted that the teaching force does not reflect the increasing diversity of the population. ${ }^{10}$

Various countries have employed a range of strategies to help them address these challenges. Competitive compensation, career prospects, career diversity, and giving teachers responsibility as professionals are important aspects of this. Active recruitment campaigns can emphasize the fulfilling nature of teaching as a profession, and seek to draw in groups who might not otherwise have considered teaching. Where teaching is seen as an attractive profession, its status can further be enhanced through selective recruitment that makes teachers feel that they will be going into a career sought after by high-fliers. All this also requires initial education to prepare new teachers to play an active role in the design and running of education, rather than just following standardized practices. 
Getting it right from the start.

Education systems can recruit high-quality teachers not just through adequate pay but also

by providing an environment in which teachers work as professionals...

...and in doing so, must look carefully at the state of labor supply and demand, and consider strategies both to bring people into teaching generally and to address specific shortages.

Various countries have shown that policy can have a significant impact on the attractiveness of teaching.

\section{MAKING TEACHING AN ATTRACTIVE CAREER CHOICE}

One of the main conclusions of the Summit has been that high-performing systems build their human resource systems by putting the energy up front in attracting, training and supporting good teachers rather than on the back end of reducing attrition and firing weak teachers. ${ }^{11}$

The OECD Programme for International Student Assessment (PISA) shows that the bestperforming education systems provide most of their students with the kind and quality of education that average performers provide only for a small elite. That requires them to deliver excellent teaching for all students. In order to achieve this, national policy reviews show that they often aim to recruit their teachers from the same pool from which all their top professionals are recruited. But people who see themselves as candidates for the professions, and the working conditions enjoyed by professionals, may not be attracted to schools organized in prescriptive work environments that use bureaucratic management to direct their work.

The Summit participants reported how they have transformed the work organization in their schools by complementing administrative forms of management with professional norms that provide the status, pay, professional autonomy, and high-quality professional education and responsibility that go with professional work. They also discussed effective systems of social dialogue. Finally, they discussed how to supply attractive forms of employment that balance flexibility with job security and grant sufficient authority for schools to manage and deploy their human resources.

Even where the recruitment of the most highly qualified graduates remains a challenge, policy makers tend to acknowledge that the quality of teaching is strongly affected by the pool of talent from which teachers are recruited. The pool from which an industry selects its professionals is influenced by some combination of the occupational status, work environment, sense of personal contribution and the financial rewards associated with a given profession. Teacher policy needs to examine these aspects closely, particularly in light of teacher shortages that many advanced economies already face and that will grow in the near future as large numbers of teachers reach retirement age. ${ }^{12}$ Even where general teacher supply and demand are in balance, many countries face shortages of specialist teachers and shortages in schools serving disadvantaged or isolated communities.

Policy responses are needed at two levels. The first concerns the nature of the teaching profession itself and teachers' work environment. These policies seek to improve the profession's general status and competitive position in the job market. The second involves more targeted responses to particular types of teacher shortages. It recognizes that that there is not a single labor market for teachers, but a set of them, distinguished by school type and characteristics such as subject specialization. ${ }^{13}$ Surveys of what teachers themselves value about their work also provide important insights into what needs to be emphasized in recruitment: the social relevance of teaching; working with young people; creativity; autonomy; and working with colleagues.

It is important to note that the status of the teaching profession is not just a static attribute of culture but has, in some countries, changed significantly. As shown in the boxes on Singapore (Box 1.1), England (Box 1.2) and Finland (Box 1.3), vigorous intervention that directly addresses the attractiveness of teaching compared to other graduate professions can make a big difference. Interesting approaches towards recruitment pursued by some countries include:

- Promotional programs targeted at groups who are "non-traditional" entrants to teaching.

- Broadening selection criteria for new teachers, with the aim of identifying applicants with the greatest potential, including interviews, preparing lesson plans, and demonstrating teaching skills. 
- Changing the role of seniority in determining teacher assignments, to avoid situations where new teachers are assigned to the more difficult and unpopular schools, further disadvantaging students there as well as potentially damaging teachers' career development.

- For desirable teaching jobs, sometimes qualities that are harder to measure, such as enthusiasm, commitment and sensitivity to students' needs, are given greater weight in applications, where these are seen to be more directly related to the quality of teaching and learning than the traditional emphases on qualifications and years of experience.

\section{Box 1.1. Throughout Singapore, teaching talent is identified and nurtured rather than being left to chance}

Singapore is notable for its comprehensive approach to identifying and nurturing teaching talent. Singapore carefully selects young people from the top one-third of the secondary school graduating class whom the government is especially interested in attracting to teaching and offers them a monthly stipend, while still in school, that is competitive with the monthly salary for fresh graduates in other fields. In exchange, these teachers must commit to teaching for at least three years. Strong academic ability is viewed as essential, as is commitment to the profession and to serving diverse student bodies. Interest in teaching is seeded early through teaching internships for high school students; there is also a system for mid-career entry, which is seen as a way of bringing real-world experience to students. Singapore keeps a close watch on occupational starting salaries and adjusts the salaries for new teachers accordingly. In effect, the country wants its most qualified candidates to regard teaching as just as attractively compensated as other professions.

After three years of teaching, teachers are assessed annually to see which of three career paths would best suit them - master teacher, specialist in curriculum or research or school leader. Each path has salary increments. Teachers with potential as school leaders are moved to middle management teams and receive training to prepare them for their new roles. Middle managers' performance is assessed for their potential to become vice principals, and later, principals. Each stage involves a range of experience and training to prepare candidates for school leadership and innovation. In Singapore, young teachers are continuously assessed for their leadership potential and given opportunities to demonstrate and learn, for example, by serving on committees, then being promoted to head of department at a relatively young age. Some are transferred to the ministry for education for a period. Potential principals are selected for interviews and go through leadership situational exercises.

Last but not least, research shows that people who have close contact with schools - such as parents who assist in classrooms, or employers who have students in workplace learning programs - often have much more positive attitudes towards teachers than people with little direct contact. This suggests that building stronger links between the schools and the community can help to enhance the status of teaching. Teachers and school leaders can play a key role in strengthening connections with families and communities as part of effective learning. This can involve eliciting greater support from stakeholders with traditional expectations about teaching by communicating current knowledge about what makes learning effective. Personalized relationships with learners and their families can be part of this process, as can after-school and extra-curricular programs, support for families as learning environments, and making the links more explicit between formal learning and life after schooling.

Employers increasingly recognize the need to provide workers with a good work-life balance and opportunities to combine work with family responsibilities and other activities. Some countries allow part-time teaching or opportunities throughout the career to gain experience outside schools through sabbatical leave, extended leave without pay, and job exchanges with industry. Although all such initiatives involve costs, those costs need to

Attractive conditions can improve morale, lower turnover and widen the teacher pool. be set against the benefits of lower staff turnover, improved morale, and introducing new knowledge and skills into schools. 


\section{Box 1.2. Reversing teacher shortages in the United Kingdom}

\section{The education authorities tackled a severe teacher shortage in England by addressing pay and work environment and launching a powerful recruitment campaign.}

When the Blair Administration took office in 1997, they had less than 28000 teacher entrants for a system that needed 35 000. Four years later, they had raised the teacher entrants number up to 40000 and it kept rising, and this was during an economic boom when everyone else was recruiting for the best and brightest. To some extent this had to do with raising compensation significantly, as well as with important changes in teachers' work environment; but a sophisticated and powerful recruiting program played a very important part in the turnaround.

The recruitment campaign, was launched with strong political and financial backing, by the Training and Development Agency (TDA) in 2000. An extra GBP 150 million was allocated to: (1) Employing leading international advertising and recruitment agencies to undertake extensive market research on the motivations and barriers to becoming a teacher, and to develop award winning marketing strategies. (2) Offering a new GBP 6000 training bursary to all trainees, as a one-off, tax-free payment to support them through their training. A "golden hello" was also introduced, of up to GBP 4 000. This amount was to be paid on employment, depending on which subject trainees were teaching. Teachers of subjects which were especially short of teachers, such as mathematics and physics, received the full amount.

By focusing on the idea of teaching "making a difference", the new campaign aimed to improve the status of teaching as a profession. It also emphasized the flexibility and diversity of the skills teachers acquire, the variety of routes into teaching and the possibility of doing it as a "first career" before moving onto other things. The advertising approach was very direct, encouraging people to call a national information line, which also allowed the TDA to collect data on people who were considering teaching and to target those with skills in shortage subjects such as mathematics and physics students.

One of the TDA's central aims was to understand its "customers" better. It divided the student population into three broad categories: (1) those planning on teaching; (2) those considering teaching; and (3) those not considering teaching. Originally, the majority of the TDA's efforts went into recruiting teachers from the "might teach" category (2). They wanted to encourage people who were seriously considering teaching as an option, but were put off by various barriers - such as the financial burden of the training. In order to refine its campaign further, the TDA then undertook more in-depth market research on potential teaching recruits. It divided the market into three main categories of potential recruits: (a) Undergraduates and recent graduates - students looking for their first job on leaving university. (b) Career finders - young people aged around 25-30 who had left university and not settled into a graduate career, but who were now looking for a career. (c) Career changers - people who had embarked on a career, but were looking for a career which would bring them more job satisfaction. During the last decade the proportion of career finders and changers amongst teacher training recruits has grown - in 2009 about $50 \%$ of teacher training recruits were over 25 . This was reflected in new advertising slogans - such as "Use your head: teach" - to appeal to people not making full use of their graduate skills in their current jobs. The latest campaign, "Turn your talent to teaching", is designed to appeal to all three categories of potential recruits.

After extensive profiling of potential recruits, the advertising agency also developed the profile of "self-interested idealists" to define potential teachers, and to shape the marketing campaigns. This acknowledged that potential teachers were motivated by making a difference and putting something back, but that they also wanted to enter a profession which would give them financial and personal satisfaction rewards.

To broaden the potential pool of teaching applicants, the TDA also developed a wide range of routes to becoming a qualified teacher. From 2006, there were as many as 32 ways of acquiring Qualified Teacher Status.

Within three months of launching the recruitment campaign, the number of people calling the national teaching recruitment helpline tripled. Unfilled teacher vacancies soon halved to less than one percent in all subjects - and the number of new recruits teaching math also doubled. Recruitment to science subjects reached its target a year earlier, in 2002-03. "Science" includes biology, popular among new teachers, as well as the priority shortage subjects of physics and chemistry. 
The essence of professional work can be seen as the acknowledgement that it is the professional, and not the supervisor, who has the knowledge needed to make the important decisions as to what services are needed and how they are to be supplied. Organizations dominated by professionals are those in which there are fewer layers of management, workers are consulted on all matters of consequence, and workers have considerable discretion with respect to diagnosing client needs and deciding which services are appropriate to address those needs. Indeed, in many professions, and for many professionals, the worker is also the manager and, in many cases, the owner as well.

\section{Box 1.3. Teachers and schools take on responsibility for reform in Finland}

Finland has made teaching a sought-after occupation by raising entry standards and giving teachers a high degree of responsibility, including roles as "action researchers" to find effective educational solutions.

Finland has raised the social status of its teachers to a level where there are few occupations with higher status. University professors are among the most highly regarded of all professionals, and even the word for teacher is the same for school teachers as for university professors. In 2010, over 6600 applicants competed for 660 available slots in primary school preparation programs in the eight universities that educate teachers, making teaching one of the most sought-after professions. ${ }^{14}$ As a result of this competitive climate, teaching is now a highly selective occupation in Finland, with highly skilled, well-trained teachers spread throughout the country.

While teachers in Finland have always enjoyed respect in society, a combination of raising the bar for entry and granting teachers greater autonomy over their classrooms and working conditions than their peers enjoy elsewhere has helped to raise the status of the profession. Finnish teachers have earned the trust of parents and the wider society by their demonstrated capacity to use professional discretion and judgment in the way they manage their classrooms and respond to the challenge of helping virtually all students become successful learners.

Since the 1980s, the Finnish system of accountability was redeveloped entirely from the bottom up. Teacher candidates are selected, in part, according to their capacity to convey their belief in the core mission of public education in Finland, which is deeply humanistic as well as civic and economic. The preparation they receive is designed to build a powerful sense of individual responsibility for the learning and well-being of all the students in their care. During their careers, they must combine the roles of researcher and practitioner. Finnish teachers are not only expected to become familiar with the knowledge base in education and human development, but are also required to write a research-based thesis as the final requirement for the Masters degree.

In education too, policy makers have often concluded that top-down initiatives alone were insufficient to achieve deep and lasting changes in practice because reforms focused on aspects that were too distant from the instructional core of teaching and learning; because reforms assumed that teachers would know how to do things they actually didn't know how to do; because too many conflicting reforms asked teachers to do too many things simultaneously; or because teachers and schools did not buy in to the reform strategy.

Over the past decade, many education systems have granted significantly more discretion to school heads and school faculties, ${ }^{15}$ something that teachers often refer to as a factor contributing to the attractiveness of the teaching profession, and something that PISA shows to be closely related to school performance, when combined with appropriate accountability arrangements. ${ }^{16}$ Finland (Box 1.3) and Ontario (Box 4.4) provide examples of how formerly centralized systems have shifted emphasis towards:

- improving the act of teaching;

- giving careful and detailed attention to implementation, along with opportunities for teachers to practice new ideas and learn from their colleagues;

- developing an integrated strategy and set of expectations for both teachers and students; and

- securing support from teachers and unions for the reforms. 
Recruitment measures can be adapted to bring in teachers from a wider range of backgrounds.
Teachers are paid less than most college graduates, but selective incentives, flexibly applied, can use scarce resources to help attract teachers where needed.
In some countries, great discretion is given to the faculty, as a whole, and its individual members. In others, more discretion is given to schools that are doing well and less to those that might be struggling. In some countries, the school head is little more than the lead teacher; in others, the authorities continue to look to the school head to set the direction and manage the faculty.

Results from PISA suggest that an emphasis on professional responsibility at the frontline does not conflict with the establishment of centralized standards and assessments; rather, these go hand in hand. ${ }^{17}$

Countries are also trying to attract different types of people into teaching, not just to overcome shortages, but also to broaden the range of teachers' backgrounds and experiences. This includes promoting the benefits of a teaching career to groups who are often under-represented among teacher ranks, such as males and those from minority backgrounds.

The following are some examples of interesting techniques various countries use to do so:

- Opening the teaching profession to individuals with relevant experience outside education, not just in vocational programs (whose teachers are required to have industrial experience in some countries).

- Recognizing the skills and experience gained outside education and reflecting those in starting salaries.

- Enabling appropriately qualified entrants, including mature student teacher trainees, to start working and earning a salary before acquiring teacher education qualifications.

- Offering more flexible approaches to teacher education that create opportunities for part-time study and distance learning, and that give credits for relevant qualifications and experience. Such alternative pathways into teaching can be particularly appealing to under-represented groups, such as males and those from minority backgrounds.

Teachers' salaries increased in real terms between 1996 and 2008 in virtually all OECD countries, but tend to remain below those of other graduates (Figure 1.1 and Annex A). Statutory salaries for teachers with 15 years of experience are, on average, below $80 \%$ of full-time earnings for 25-64 year-olds with tertiary education, and $60 \%$ or below in the Czech Republic, Hungary, Iceland, Israel, Italy, Slovenia and the United States. ${ }^{18}$ At the same time, other aspects of teachers' employment conditions, such as vacations, relative job security and pensions, are often more generous than in other occupations. OECD research suggests that where teachers' salaries are low relative to professions requiring similar qualifications, teacher supply appears to be quite price-elastic: for a given percentage increase in teachers' relative salaries, the supply of potential teachers increases by a greater percentage. In countries where teachers' salaries are already relatively high, teacher supply tends to be less elastic: a given percentage rise in salary produces a lower percentage increase in supply. ${ }^{19}$

Nevertheless, the large size of the teaching workforce means that to raise salaries acrossthe-board by even a few percentage points is very costly. Furthermore, the teacher labor market is diverse, and teacher recruitment difficulties vary by type of school, subject specialization, and region. Also, in many countries the problems of teacher shortages and high turnover of staff are felt most acutely in schools that are already disadvantaged. Some countries are therefore targeting larger salary increases to schools with particular needs or teacher groups in short supply (Chapter 3). For example, some targeted policy initiatives aim to attract teachers in subjects such as mathematics, science, technology, and vocational subjects.

Fee waivers, scholarships and forgivable loans are some of the financial incentives being proposed to attract such people into teacher education; and salary bonuses and recognition 
of work experience are provided for those who already have the types of qualifications that are in short supply. Some countries offer substantial salary allowances for teaching in difficult areas, transportation assistance for teachers in remote areas, or bonuses for teachers with skills in short supply to help ensure that all schools are staffed with teachers of similar quality.

Also worthy of attention are non-salary strategies, such as less class contact time or smaller classes, for schools in difficult areas or that have particular educational needs.

\section{Figure 1.1}

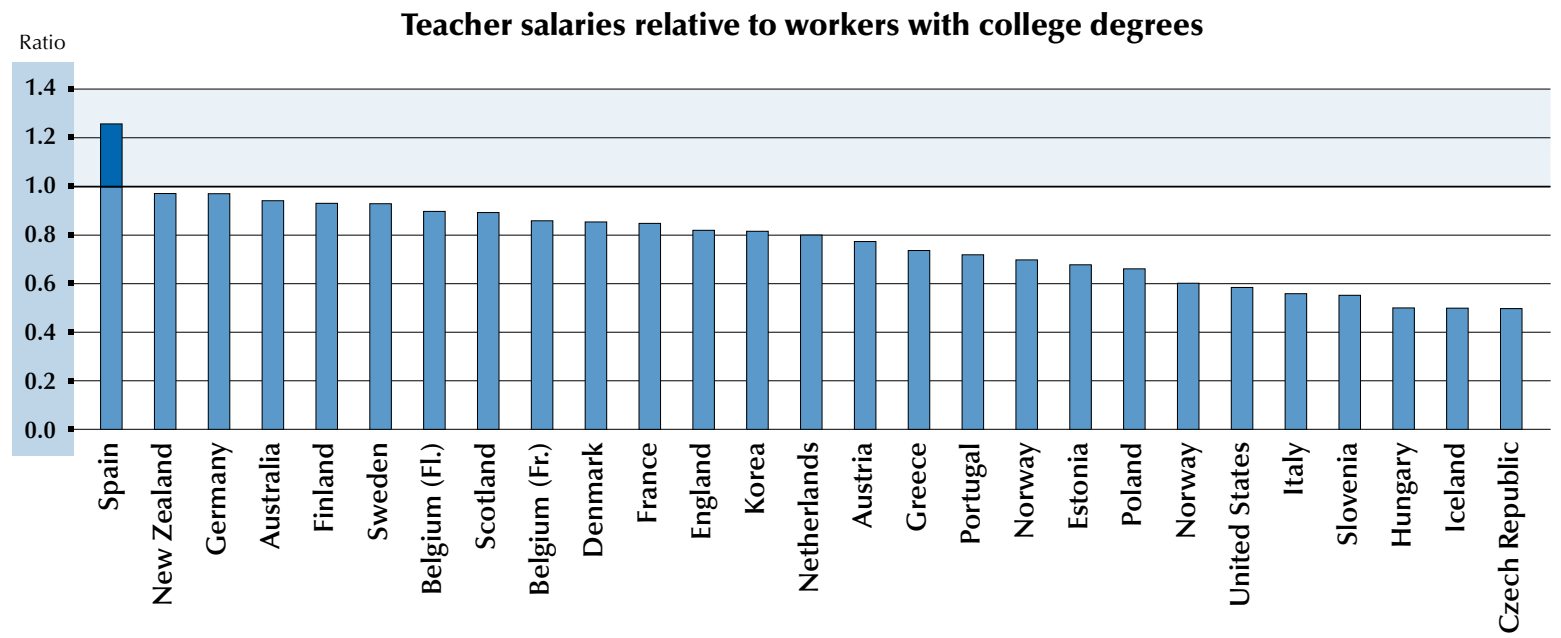

Countries are ranked in descending order of the ratio of salary after 15 years of experience/minimum training to earnings for full-time full-year workers with tertiary education aged 25 to 64 (latest available year).

Source: OECD, Education at a Glance 2010, Table 3.1 (continued).

At the Summit, Norway reported on work with media to reduce the teacher bashing that had been prevalent in the media. Other countries such as China and Japan reported on public recognition days for teachers when respect for the profession is emphasized. ${ }^{20}$

All this said, policies to encourage more people to enter teaching are unlikely to pay off if high-quality candidates find it hard to gain teaching posts. The best candidates, who are likely to have good job prospects outside teaching, may not be willing to wait in a lengthy queue or endure a succession of short-term teaching assignments in difficult schools. Wellstructured and well-resourced selection processes and programs of induction that ensure that the best candidates get the available jobs are therefore critical. Reducing the weight given to seniority in ranking applicants for teaching vacancies can also help reduce the risk that new teachers will be disproportionately assigned to difficult schools.

\section{ENSURING HIGH-QUALITY INITIAL TEACHER EDUCATION}

Initial teacher education varies significantly across countries, and it is beyond the scope of this report to assess related policies and practices. However, OECD research has identified some principles that are worth noting:21

- Education systems benefit from clear and concise profiles of what teachers are expected to know and be able to do in specific subject areas. Such profiles can guide initial teacher education, teacher certification, teachers' on-going evaluation, professional development and career advancement, and also help assess the extent to which these different elements are effective. The profiles can reflect the school's learning objectives and profession-wide understanding of what counts as accomplished teaching (Box 3.2).
As important as salaries is the professional public image of teachers.

The best potential candidates need access to good teaching jobs.

High-performing countries have found ways of educating teachers to become more effective and play an active role in reform. 
- Many countries have moved their initial teacher education programs towards a model based less on academic preparation and more on preparing professionals in school settings, with an appropriate balance between theory and practice. In these programs, teachers get into classrooms earlier, spend more time there and get more and better support in the process. This can include both extensive course work on how to teach with a strong emphasis on using research based on state-of-the-art practice - and more than a year teaching in a designated school, associated with the university, during which time the teacher is expected to develop and pilot innovative practices and undertake research on learning and teaching.

- More flexible structures of initial teacher education can be effective in opening up new routes into the teaching career, without compromising the rigor of traditional routes. The stages of initial teacher education, induction and professional development need to be interconnected to create a lifelong learning framework for teachers. In many countries, teacher education is not just providing sound basic training in subject-matter knowledge, pedagogy related to subjects, and general pedagogical knowledge; it also seeks to develop the skills for reflective practice and on-the-job research. Increasingly, initial teacher education tends to place more emphasis on developing the capacity of teachers in training to diagnose student problems swiftly and accurately and to draw from a wide repertoire of possible solutions those that are appropriate to the diagnosis. Some countries provide teachers with the research skills needed to enable them to improve their practice in systematic ways. For example, both in Finland (Box 1.3), Japan and the Shanghai province of China (Box 1.4), teachers are trained to be action researchers in practice, with the ability to work out ways of ensuring that any student starting to fall behind is helped effectively.

In addition, some countries have moved from a system in which teachers are recruited into a larger number of specialized colleges of teacher education, with relatively low entrance standards, to a system of a relatively smaller number of university-based teacher-education colleges with relatively high entrance standards and relatively high status in the university. 


\section{Box 1.4. Preparing teachers to lead improvement}

\section{In Japan, all teachers participate in regular lesson studies in their schools.}

The Japanese tradition of lesson study in which groups of teachers review their lessons and how to improve them, in part through analysis of student errors, provides one of the most effective mechanisms for teachers' self-reflection as well as being a tool for continuous improvement. Observers of Japanese elementary school classrooms have long noted the consistency and thoroughness with which a math concept is taught and the way in which the teacher leads a discussion of mathematical ideas, both correct and incorrect, so that students gain a firm grasp on the concept. This school-by-school lesson study often culminates in large public research lessons. For example, when a new subject is added to the national curriculum, groups of teachers and researchers review research and curriculum materials and refine their ideas in pilot classrooms over a year before holding a public research lesson, which can be viewed electronically by hundreds of teachers, researchers and policymakers.

The tradition of lesson study in Japan also means that Japanese teachers are not alone. They work together in a disciplined way to improve the quality of the lessons they teach. That means that teachers whose practice lags behind that of the leaders can see what good practice is. Because their colleagues know who the poor performers are and discuss them, the poor performers have both the incentive and the means to improve their performance. Since the structure of the East Asian teaching workforce includes opportunities to become a master teacher and move up a ladder of increasing prestige and responsibility, it also pays the good teacher to become even better.

\section{In China, teachers are trained to be action researchers in effective practice, with the best teachers going on to support new teachers and helping to improve lesson quality.}

The authorities in the Shanghai province of China emphasize giving prospective teachers the skills they will need for action research, and their method for improving their education system over time relies on research performed by teachers. As in Finland (Box 1.3), all students in Shanghai are expected to perform at high levels and teachers are expected to make sure that no student, literally, will be allowed to fall behind. This makes it essential that teachers identify students who are just beginning to flounder, diagnose the problem, and have the skills and knowledge needed to create a large and constantly updated reservoir of solutions to the student performance problems they have diagnosed.

During the course of their careers, teachers in Shanghai are involved in subject-based "teaching-study groups" to improve teaching at the grassroots level on a day-to-day basis. There are timetabled sessions when the study group meets, often with related personnel, such as laboratory assistants, to draw up very detailed lesson schemes for a particular topic the following week. The lesson plan serves not only as a guide for the teacher during the lesson, but also as documentation of the teacher's professional performance. During actual teaching, teachers may observe each other or may be observed by peers. For example, when a change in curriculum introduces a new teaching topic, teachers may be observed by new teachers, so these can learn from more experienced colleagues; by senior teachers, for mentoring purposes; or by the school principal, for monitoring or to provide constructive development assistance. Sometimes, teachers are expected to teach demonstration lessons, called public lessons, for a large number of other teachers to observe and comment upon.

This structured organization of teaching in Shanghai is not only a means for administration; it is also a major platform for professional enhancement. Teachers in Shanghai are classified into four grades that indicate their professional status. Promotion from one grade to the next often requires the capacity to give demonstration lessons, contribute to the induction of new teachers, publish in journals or magazines about education or teaching, and so forth. The provincial office often identifies the best of the teachers who emerge from evaluation processes and relieves them of some or all of their teaching duties so that they can give lectures to their peers, make demonstrations, and coach other teachers on a district, provincial and even national level. Carefully picked schools are often asked to pilot new programs or policies before they are scaled-up, and the best teachers in those schools are enlisted as co-researchers to evaluate the effectiveness of the new practices. 

Improvements must come partly through the transformation of the present teaching force, with teachers expected to be able to adapt to new knowledge and demands during their careers.

The requirements of teachers change continuously, so pre-service education is not enough, and...

... continuous professional development is needed to update skills and knowledge in a range of ways.
As important as the recruitment and selection of promising graduates is, it can only be one of several components of human resource management in education. The frequently cited claim that the best-performing education systems all recruit their teachers from the top-third of graduates - however that is defined - is not supported by evidence. Successful reform cannot wait for a new generation of teachers; it requires investment in the present teacher workforce, providing quality professional development, adequate career structures and diversification, and enlisting the commitment of teachers to reform (Boxes 4.1 to 4.6).

The Summit concluded that making teaching an attractive and effective profession requires supporting continuous learning, developing career structures to give new roles to teachers, and engaging strong teachers as active agents in school reform, not just implementers of plans designed by others. It also requires strengthening the knowledge base of education and developing a culture of research and reflection in schools so that teaching and learning can be based on the best available knowledge. ${ }^{22}$

The ILO/UNESCO Committee of Experts on the Application of the Recommendations concerning Teaching Personnel notes in its 2009 report that "Teaching career structures... are evolving to encourage better teaching practices and incentives for teachers to remain in teaching, but much more needs to be done to link teacher education and professional development, evaluation and career progression. Evidence from international surveys point to a general lack of professional development support adapted to the needs of teachers and learners." 23

The following analysis looks at how the individual development of teachers can be improved and how greater collaboration among teachers can improve the quality of teaching.

\section{MEETING THE NEED FOR PROFESSIONAL DEVELOPMENT}

In many countries, the role and functioning of schools are changing - and so is what is expected of teachers. They are asked to teach in increasingly multicultural classrooms. They must place greater emphasis on integrating students with special learning needs, both special difficulties and special talents, in their classes. They need to make more effective use of information and communication technologies for teaching. They are required to engage more in planning within evaluative and accountability frameworks. And they are asked to do more to involve parents in schools. No matter how good the pre-service education for teachers is, it cannot be expected to prepare teachers for all the challenges they will face throughout their careers.

The development of teachers beyond their initial education can serve a range of purposes, including:

- updating individuals' knowledge of a subject in light of recent advances in the area;

- updating individuals' skills and approaches in light of the development of new teaching techniques and objectives, new circumstances, and new educational research;

- enabling individuals to apply changes made to curricula or other aspects of teaching practice;

- enabling schools to develop and apply new strategies concerning the curriculum and other aspects of teaching practice;

- exchanging information and expertise among teachers and others, e.g. academics and industrialists; or

- helping weaker teachers become more effective.

Several aspects have shown to be central to successful professional development.
In seeking to meet teachers' professional development requirements, policy makers and practitioners need to consider both how to support and encourage participation and how to ensure that opportunities match teachers' needs. This needs to be balanced with the 
cost in terms of both finance and teachers' time. OECD research identifies several aspects as central to successfully bridging the gap between the ideal learning environment and day-to-day practice: ${ }^{24}$

- Well-structured and well-resourced induction programs can support new teachers in their transition to full teaching responsibilities before they obtain all the rights and responsibilities of full-time professional teachers. In some countries, once teachers have completed their pre-service education and begun their teaching, they begin one or two years of heavily supervised teaching. During this period, the beginning teacher typically receives a reduced workload, mentoring by master teachers, and continued formal instruction (Figure 2.1).

- Effective professional development needs to be on-going, include training, practice and feedback, and provide adequate time and follow-up support. Successful programs involve teachers in learning activities that are similar to those they will use with their students, and encourage the development of teachers' learning communities.

- Teacher development needs to be linked with wider goals of school and system development, and with appraisal and feedback practices and school evaluation.

- There is often a need to re-examine structures and practices that inhibit inter-disciplinary practice and to give more room for teachers to take time to learn deeply, and employ both inquiry and group-based approaches, especially in the core areas of curriculum and assessment.

\section{Figure 2.1}

\section{Percentage of teachers without mentoring and induction}

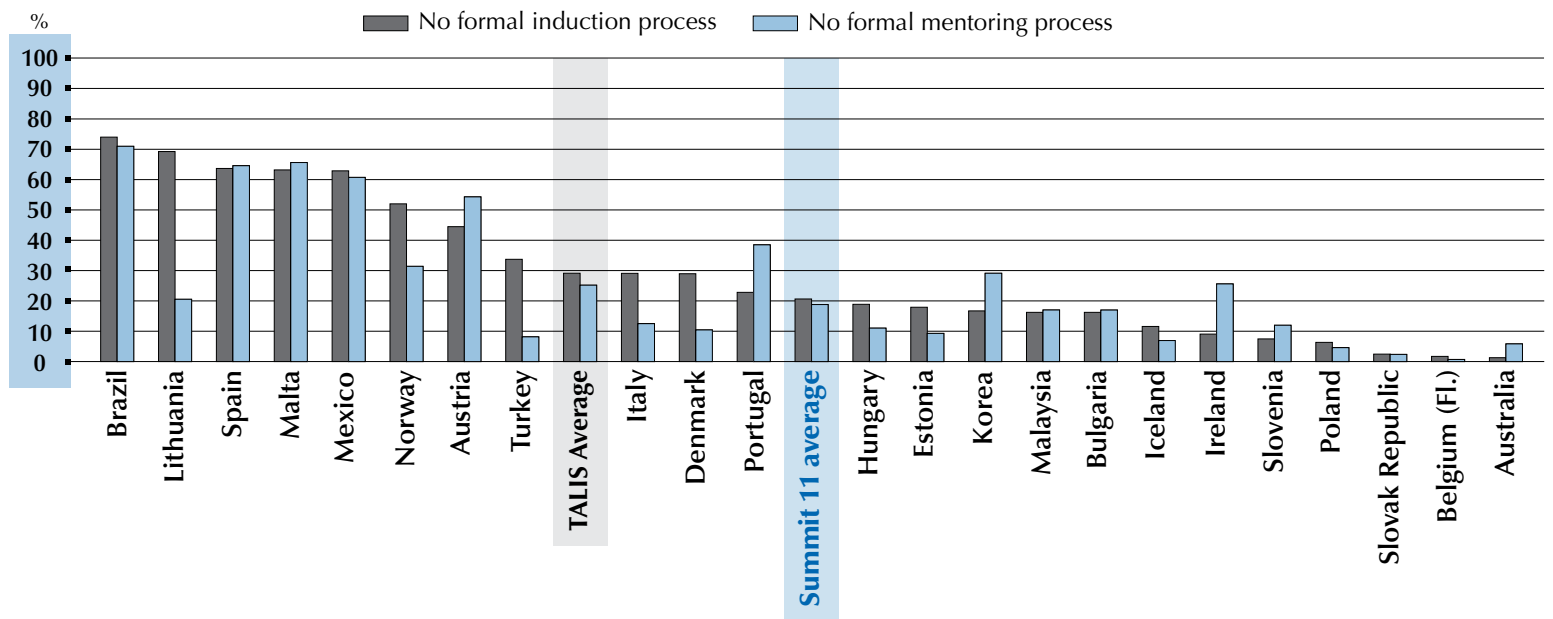

Note: "Summit 11" represents the average figure for the countries that were represented in the International Summit on the Teaching Profession. Countries are ranked in descending order of the percentage of teachers in schools that do not have a formal induction programme. Source: OECD (2009), Creating Effective Teaching and Learning Environments: First Results from TALIS, Table 3.6.

In some countries, ongoing professional development already plays an important role. In the Chinese province of Shanghai, each teacher is expected to engage in 240 hours of professional development within five years. Singapore provides teachers with an entitlement of 100 hours of professional development per year to keep up with the rapid changes occurring in the world and to be able to improve their practice. More generally, results from the Teaching and Learning International Survey (TALIS) show that across countries almost $90 \%$ of teachers participated in some form of professional development over an 18-month period and, on average, spent just under one day per month in professional development ${ }^{25}$ (Figures 2.2 and 2.3).
The extent of in-service teacher education varies greatly across and within countries... 


\section{Figure 2.2}

\section{Comparison of impact and participation by types of development activity}

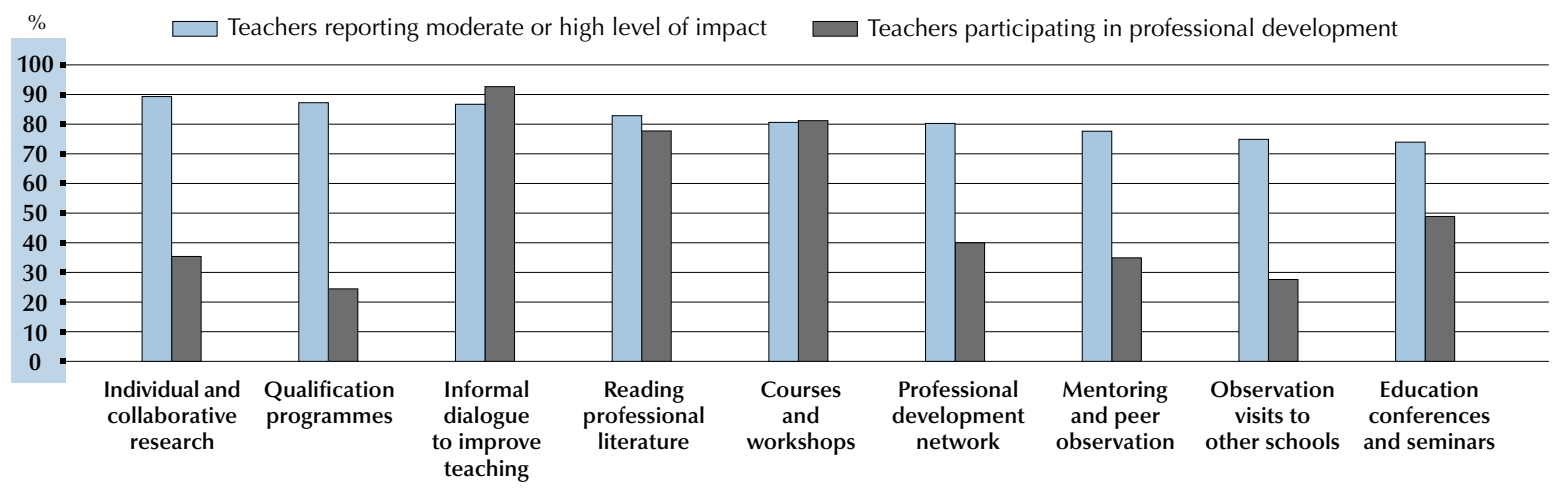

Activities are ranked in descending order of the percentage of teachers reporting a moderate or high impact of the professional development they took.

Source: OECD (2009), Creating Effective Teaching and Learning Environments: First Results from TALIS, Tables 3.2 and 3.8.

\section{Figure 2.3}

Reasons for not taking more professional development

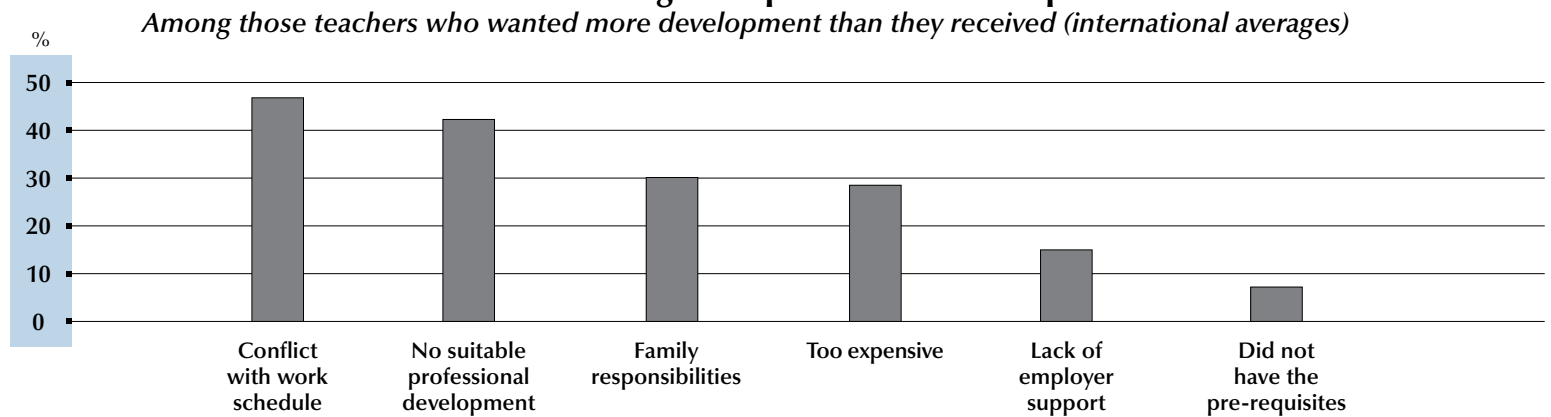

Reasons are ranked in descending order of frequency with which the barrier was reported by teachers.

Source: OECD (2009), Creating Effective Teaching and Learning Environments: First Results from TALIS, Table 3.7.

...but mostly still takes the form of one-off events rather than upgrading qualifications or collaborative research, which,

teachers report, have the greatest impact.
However, there is considerable variation in the incidence and intensity of teacher participation in professional development both across and within countries; ${ }^{26}$ and older teachers tend to engage in less professional development than younger ones. The types of development undertaken by teachers explain some of these variations. Countries in which a high percentage of teachers take part in "qualification programs" or "individual and collaborative research" tend to have a higher average number of days of development but only a small minority of teachers tend to participate in these activities.

Teachers consider better and more targeted professional development as an important lever towards improvement. TALIS data show that teachers' participation in professional development goes hand-in-hand with their mastery of a wider array of methods to use in the classroom, even if it is not clear to what extent professional development triggers or responds to the adoption of new techniques. TALIS data also identify close associations between professional development and a positive school climate, teaching beliefs, cooperation between teachers and teacher job satisfaction.

However, schools and systems need to better match the costs and benefits of, and supply and demand for, professional development. Results from TALIS show that, across countries, relatively few teachers participate in the kinds of professional development that they believe has the largest impact on their work, namely qualification programs and individual and collaborative research, even if those who do commit considerable time and money to these courses consider them effective (Figure 2.2 and Annex A). 


\section{Box 2.1. Innovative teacher-preparation programs in the United States}

\section{Boston's Teacher Residency is preparing high-flying graduates to fill shortages in the city's schools.}

The Boston Teacher Residency (BTR), established in 2003, is a teacher-preparation program that recruits highperforming college graduates and professionals and prepares them to teach in Boston schools. The program focuses on mastering the skills that teachers will need to be effective in the public schools in which teachers will work, emphasizing clinical training and pairing residents with experienced classroom teachers. Residents begin the program with a two-month summer institute, and then spend their first year in a classroom four days a week, spending the fifth day attending courses and seminars. This approach allows residents to master simultaneously both the theory and practice of teaching. After their first year, residents receive an initial teacher license and a master's degree in education, and continue to receive support from BTR in the form of induction coaching, courses and seminars, and placement in collaborative clusters within schools. A study of the program's impact on student achievement is underway, but early indicators of success include a rigorous recruitment and selection process in which only $13 \%$ of applicants are admitted, three-year retention rates of $85 \%$ (far above the U.S. average for urban schools), growth of the program's outputs to fill $60 \%$ of Boston's annual need for math and science teachers, and highly favorable reviews from school principals, with $96 \%$ of principals saying they would recommend hiring a BTR graduate to another principal. BTR recently received a USD 5 million "development" grant under the U.S. Department of Education's Investing in Innovation Fund, which seeks to identify and scale-up promising and proven practices in teacher education and other priority areas.

\section{Statewide programs in Colorado, Missouri, New Jersey and Vermont}

A recent study highlighted four states within the U.S. that actively support teacher professional learning and growth, whose students exhibit strong academic achievement on the National Assessment of Educational Progress (NAEP), and whose teachers report a high level of participation in professional development. The four states described in the study are characterized by: (1) The adoption of standards or guidelines for teacher professional development; (2) the requirement of induction and mentoring programs for beginning teachers; (3) a state-level organization or professional board that oversees teacher licensing, professional teaching standards and professional development; and (4) the provision of a range of support and incentives for professional learning and growth. ${ }^{27}$

Highlights of the states' practices and policies are described below:

Colorado: All districts in Colorado are required to provide a state-approved induction program for beginning teachers, and teachers must complete the induction program before they are eligible for the next level of licensure. The state also conducts a biennial teaching conditions survey that collects data on the quality of teachers' professional development opportunities. The survey asks new teachers about a range of induction support: orientation meetings, access to Professional Learning Communities (PLCs), release time to observe other teachers, time to meet with one's mentor during school hours, and a reduced workload. In addition, all teachers must complete 90 hours of professional development every five years for licensure renewal and the state provides guidelines for this professional development, including the guideline that learning activities must be within a teachers' endorsement area(s). The state supports several state-level or statewide initiatives that offer professional development as one component of their programs. For example, the state has a "Closing the Achievement Gap" initiative which awards grants to a limited number of districts for improving student achievement; a portion of these funds can be used to help teachers improve instructional practices.

Missouri: Missouri's Outstanding Schools Act requires districts to allocate one percent of state funding to local professional development efforts and an additional one percent of the state's overall budget is dedicated to a statewide network of professional development centers (Regional Professional Development Centers or "RPDCs"). These RPDCs are overseen by the Missouri Department of Education and they provide a common vision for professional development. (Funding for the centers was withheld in the challenging budget year of 2010, but nine of the 11 centers have found alternative funding sources so their work is continuing.) Through statute, the state also requires school-based "Professional Development Committees" (or PDCs), composed of teachers, to make decisions on how earmarked professional development funds should be spent. 
New Jersey: New Jersey has a statewide Professional Teaching Standards Board which is comprised of teachers and other stakeholders and has created structures and standards for reflective and collaborative professional development work. The state requires mentoring for new teachers, data-driven professional development plans for individual teachers, and school-level committees that create school-level professional development plans. The state supports 33 Professional Learning Community (PLC) Lab Schools and assesses the degree to which the state's professional development standards are reflected in school practice.

Vermont: Vermont has guidelines for the professional development required for teachers' licensure renewal. In order to apply for licensure renewal, teachers are required to present a portfolio of their work, their past professional development and their planned, future learning activities to the regional professional standards board. Through state-supported Educational Services Agencies and intermediary organizations, the state is attempting to coordinate statewide professional development and enable districts to pool their resources and share knowledge. Coaches from one organization - Vermont's School Reform Initiative (SRI) chapter work closely with staff in individual schools to help them strengthen their collaborative skills, learn how to give and receive feedback on their work, and build the capacity of teacher leaders. Vermont also has many homegrown educational programs that have arisen from a combination of university partnerships, federal grants and "symbiotic relationships with state initiatives". One example is the Vermont Math Initiative (VMI) which used state grant monies to help start a three-year master's program which provides comprehensive mathematics training for $\mathrm{K}-8$ teachers.

Teacher demand for professional development is of ten not met, sometimes for lack of time, sometimes for lack of opportunity...

...and these shortfalls are likely to undermine the capacity of education systems to adapt to changing needs, especially in certain areas, like adopting ICT and serving students of varied

backgrounds.
Conversely, the types of activities that teachers consider less effective, namely one-off education conferences and seminars, show comparatively high participation rates. This being said, research on how the incidence and intensity of different types of professional development activities influences learning outcomes is still limited.

Despite high levels of participation in development activities, the professional development needs of a significant proportion of teachers are often not fully met. The TALIS survey found that:

- Fifty five percent of the teachers surveyed reported that they wanted more professional development than they received during the 18-month survey period. The extent of unsatisfied demand is sizeable in every country, ranging from $31 \%$ to over $80 \%$.

- Across countries, teachers who were more likely to report unsatisfied demand were in public schools, females and under 40 years of age.

- Across countries, the aspects of teachers' work with greatest development need are "teaching special-needs students", followed by "information and communication technology teaching skills" and "student discipline and behavior".

What prevents teachers from undertaking as much professional development as they would like? The most common reason, cited by nearly half of teachers in TALIS, was conflict with their work schedule (Figure 2.3 and Annex A). However, almost as many cited the lack of suitable opportunities for professional development, and these teachers also generally engaged in less development activity.

But it is not just a question of producing more of the same professional development. Teachers consistently reported that their greatest need for professional development was in learning how to handle differences in student learning styles and backgrounds, using information and communication technologies effectively, and improving student behavior (Figure 2.4). These responses offer some direction on where future efforts should focus, and suggest that a sound assessment of provision and support of development is important. 
Areas of greatest need for teacher professional development

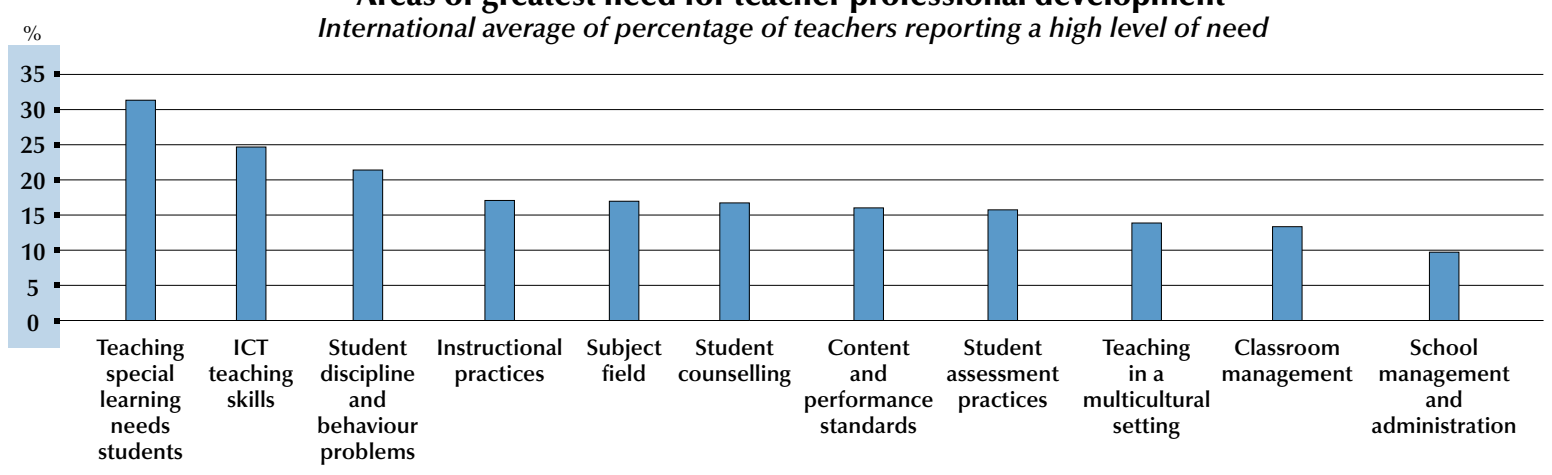

Areas are ranked in descending order of the international average where teachers report a high level of need for development.

Source: OECD (2009), Creating Effective Teaching and Learning Environments: First Results from TALIS, Table 3.4.

Of course, a certain level of unsatisfied demand is to be expected; it is only natural that a certain proportion of teachers will, at some time, not feel fully equipped to carry out their work effectively. Nonetheless, the extent of unsatisfied demand appears large, and in some countries the great majority of teachers report that they need more professional development than they receive. The extent to which this undermines the effectiveness of these teachers is difficult to assess; but it is equally difficult to imagine that such deficits are not to some extent detrimental to effective teaching and learning. The cost of providing additional professional development needs to be seen in relation to the cost of not providing it, in terms of lost opportunities for students to learn.

Even if there is no country in which the professional development of teachers is completely free, TALIS data indicate that teachers in most countries feel that the level of support they receive, in terms of finance and separately scheduled time in which to undertake development activities, is significant. In the participating countries, an average of around two-thirds of teachers pay nothing for these activities, and a similar proportion receive allocated time. Schools and public authorities clearly make a significant investment in teachers' professional development (Figure 2.5 and Annex A).

The fact that a sizeable proportion of teachers underwrite the cost of their professional development is evidence that many teachers are contributing their share of the cost of advancing their career if they cannot find free programs of adequate quality. In fact, the data show that where teachers paid for their own professional development, they tended to participate in more of it: those who paid the full cost took over twice as many teachereducation courses as those who received them for free. This partly reflects the fact that courses that are paid for tend to lead to professional qualifications and are more timeconsuming. This suggests that free provision is not necessarily the only way of stimulating participation, at least when teachers are seeking to further their careers and their earnings prospects, such as when they prepare for becoming head teachers, inspectors or teachers at a superior educational level.

\section{FOSTERING AN ENVIRONMENT FOR EFFECTIVE TEACHER COLLABORATION}

Teachers can do more, and should be encouraged to do more, to share their expertise and experience systematically in ways that go beyond the mere exchange of information. Teachers report relatively infrequent collaboration with colleagues within the school, beyond a mere exchange of information and ideas; direct professional collaboration to enhance student learning is rarer. ${ }^{28}$ Understanding that collaboration takes time, some countries are providing teachers with some scheduled time or salary supplement to encourage them to engage in such co-operation.
Most professional development is provided free; but in some countries teachers who contribute financially tend to participate in and benefit more from these activities.

Teachers work together relatively rarely; but when they do, they tend also to work well with students. 


\section{Figure 2.5}

\section{Support for professional development}

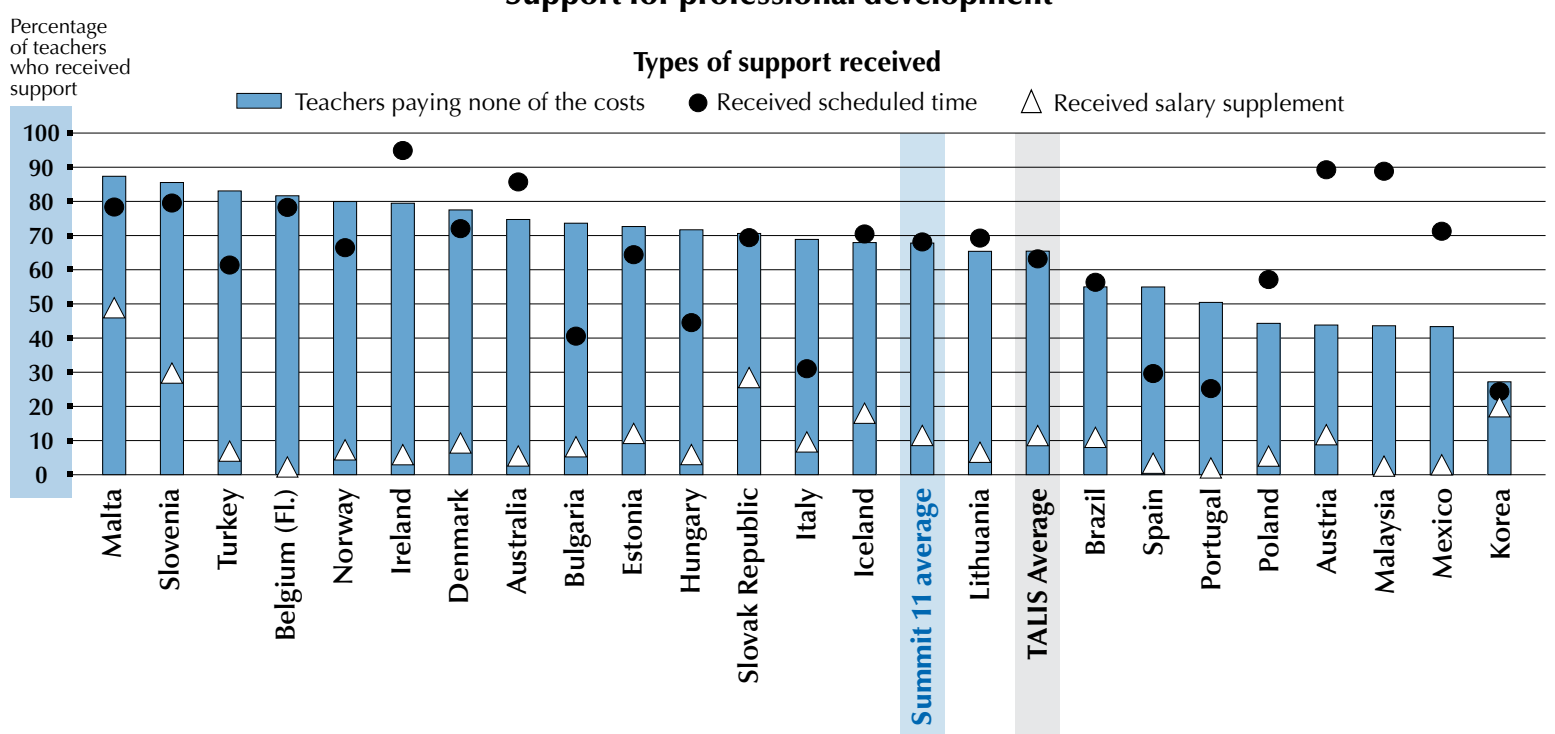

Note: "Summit 11" represents the average figure for the countries that were represented in the International Summit on the Teaching Profession. Countries are ranked in descending order of percentage of teachers having paid none of the cost of professional development. Source: OECD (2009), Creating Effective Teaching and Learning Environments: First Results from TALIS, Table 3.5.

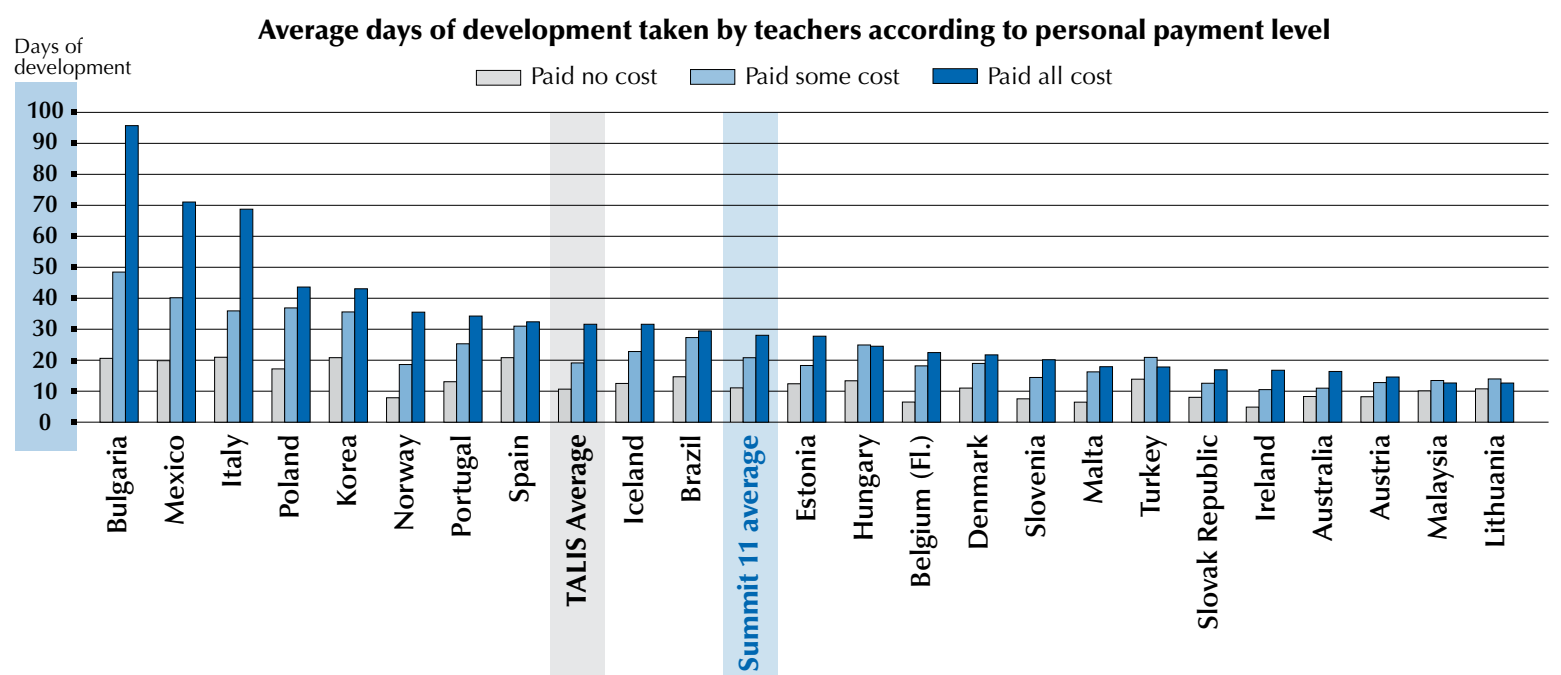

Note: "Summit 11" represents the average figure for the countries that were represented in the International Summit on the Teaching Profession. Countries are ranked in descending order of percentage of teachers having paid all of the cost of development they took.

Source: OECD (2009), Creating Effective Teaching and Learning Environments: First Results from TALIS, Table 3.5a, available on line.

Teachers who exchange ideas and information and co-ordinate their practices with other teachers also report more positive teacher-student relations at their school. Thus, it may be reasonable to encourage teachers' co-operation in conjunction with improving teacher-student relations, as these are two sides of a positive school culture. Positive teacher-student relations are not only a significant predictor of student achievement, they are also closely related to individual teachers' job satisfaction (Figure 2.6). This finding emphasizes the role of teachers' positive evaluations of the school environment for effective education and teacher well-being. Efforts to improve school climate are particularly important in larger public schools attended by students with low average ability. Several of the East Asian countries provide interesting models for building on professional teacher collaboration to make the most of their top-performing teachers (Boxes 1.4 and 1.5). 


\section{Figure 2.6}

\section{Students' views of teacher-student relations}

Index of teacher-student relations based on the reports of 15-year-old students

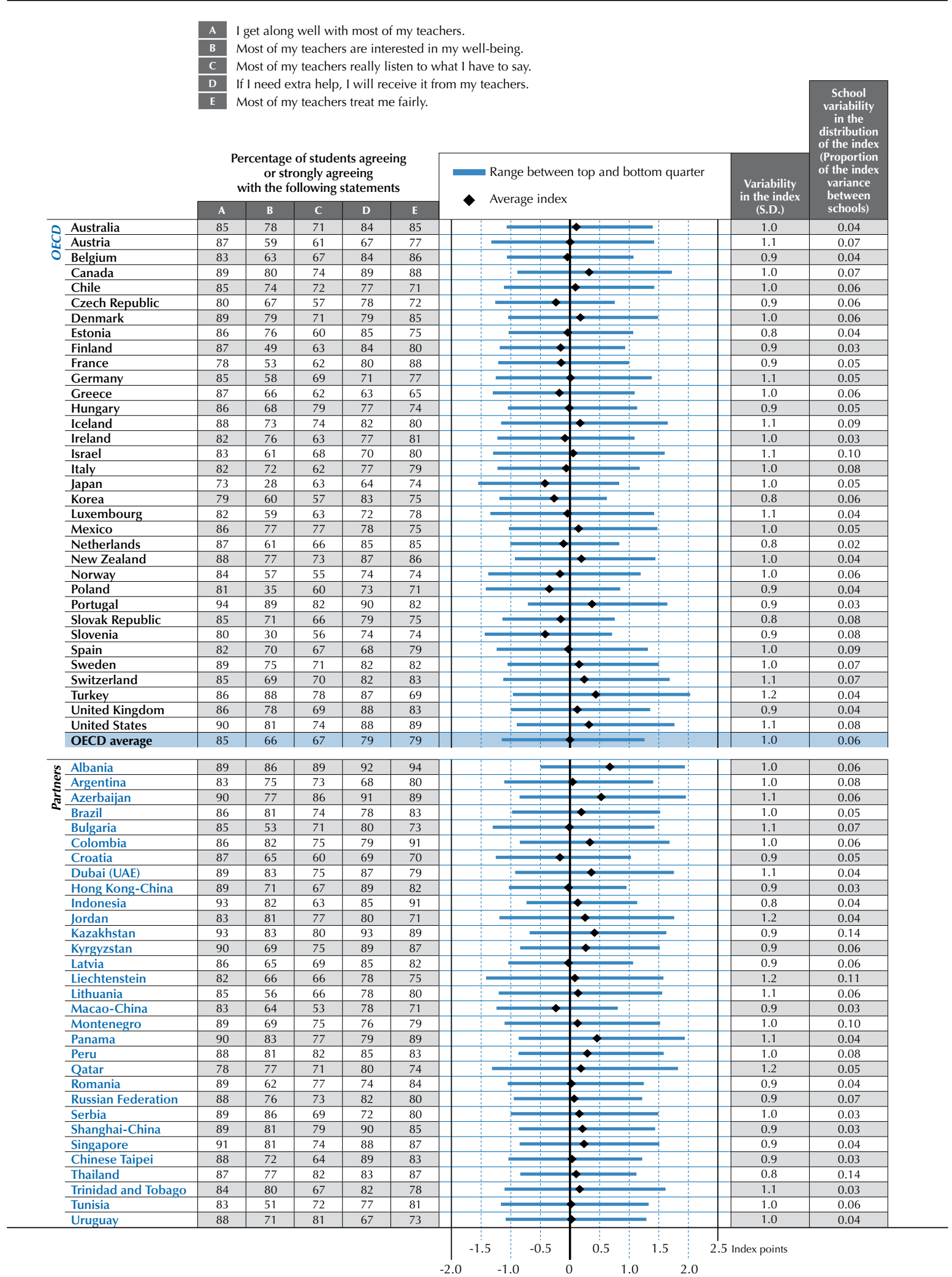

Note: Higher values on the index indicate positive teacher-student relations

Source: OECD, PISA 2009 Database, Table IV.4.1. 
Finding alternatives to guaranteeing teachers a job for life has not been easy...

...and experience in OECD countries is that it is not easy to graft features from a markedly different system onto a well-established employment model.

In many successful systems, schools have become more involved in personnel management.

\section{ESTABLISHING EFFECTIVE EMPLOYMENT CONDITIONS}

The predominant model for teacher employment in OECD countries is "career-based" public service in which entry is competitive, career development is extensively regulated and lifetime employment is largely guaranteed. ${ }^{29}$ In a situation where teachers are not commonly removed for unsatisfactory performance, the quality of teachers depends mainly on setting high standards of entering teacher-preparation programs, on the quality of their initial preparation, and on the attention given to the quality of their preparation following their initial induction. Under career-based systems, the risk is that the quality of the teaching force depends excessively on getting initial recruitment and teacher education right, and that any improvement over time will take many years to affect most serving teachers. Moreover, career advancement can become heavily dependent on adhering to organizational norms, which helps to ensure uniformity and predictability of service and a strong group ethos, but can make systems inflexible to change and ill-equipped to serve diverse needs in different settings.

In some countries, public servants are required to apply for specific positions by showing that their competencies match specific job requirements, rather than having a guaranteed career. However, this can increase recruitment and management costs, and make it harder to develop shared values and provide consistent service. Another approach has been to introduce more contract or temporary employment positions in parallel with career-based systems. This opens up possibilities for external recruitment, gives local managers more scope for personnel decisions, and institutes management by objectives. However, the general experience in OECD countries is that it is not easy to graft features from a markedly different system onto a well-established employment model. Those in career-based systems who have met demanding entrance criteria and accepted relatively low starting salaries can feel threatened by a less predictable future. Those accustomed to professional status and autonomy derived from their specialist skills may feel threatened by moves to institute system-wide standards. The OECD's Teachers Matter study, PISA and the annual data collection Education at a Glance identify a number of trends in country reforms that are highlighted in this chapter.

Successful enterprises often report that personnel selection is the most important set of decisions that they make. In the case of teaching, the evidence suggests that all too often the selection process follows rules about qualifications and seniority that bear little relationship to the qualities needed to be an effective teacher. The sheer size of school systems in many countries means that the process of teacher selection is often highly impersonal, and it is hard for teachers to build a sense of commitment to the schools where they are appointed - or for the schools to build a sense of commitment to them. Data from PISA suggest that many of the high-performing education systems have responded by giving schools more responsibility - and accountability - for teacher selection, working conditions, and development (Figure 2.7 and Annex A).

The OECD's Teachers Matter study describes how school leaders in many of the bestperforming education systems actively seek out and develop the best possible teachers and, with personal interviews and visits to schools by candidates, seek to optimize the match between applicants and school needs. The study suggests that such approaches work best where parallel steps are taken to ensure that accountability, efficiency and equity are not jeopardized, for example by developing school leaders' skills in personnel management, providing disadvantaged schools with greater resources with which to recruit effective teachers, making information more accessible in the teacher labor market, and monitoring the outcomes of a more decentralized approach and adjusting accordingly. However, successful decentralization of personnel management, and school decision-making more generally, require that central and regional authorities help to ensure an adequate and equitable distribution of teacher resources throughout the country. It is also important to have independent appeals procedures to ensure fairness and protect teachers' rights. 


\section{Figure $2.7(1 / 2)$}

\section{How much autonomy individual schools have over resource allocation}

Percentage of students in schools of 15-year-olds whose principals reported that only "principals and/or teachers", only "regional and/or national education authority" or both "principals and/or teachers" and "regional and/or national education authority" have a considerable responsibility for the following tasks

Selecting teachers for hire

Dismissing teachers

Establishing teachers' starting salaries

Determining teachers' salaries increases

Formulating the school budget

Deciding on budget allocations within the school

1 Only "principals and/or teachers"

2 Both "principals and/or teachers" and "regional and/or national education authority"

3 Only "regional and/or national education authority"

Range between top and bottom quarter

- Average index

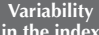
(S.D.)

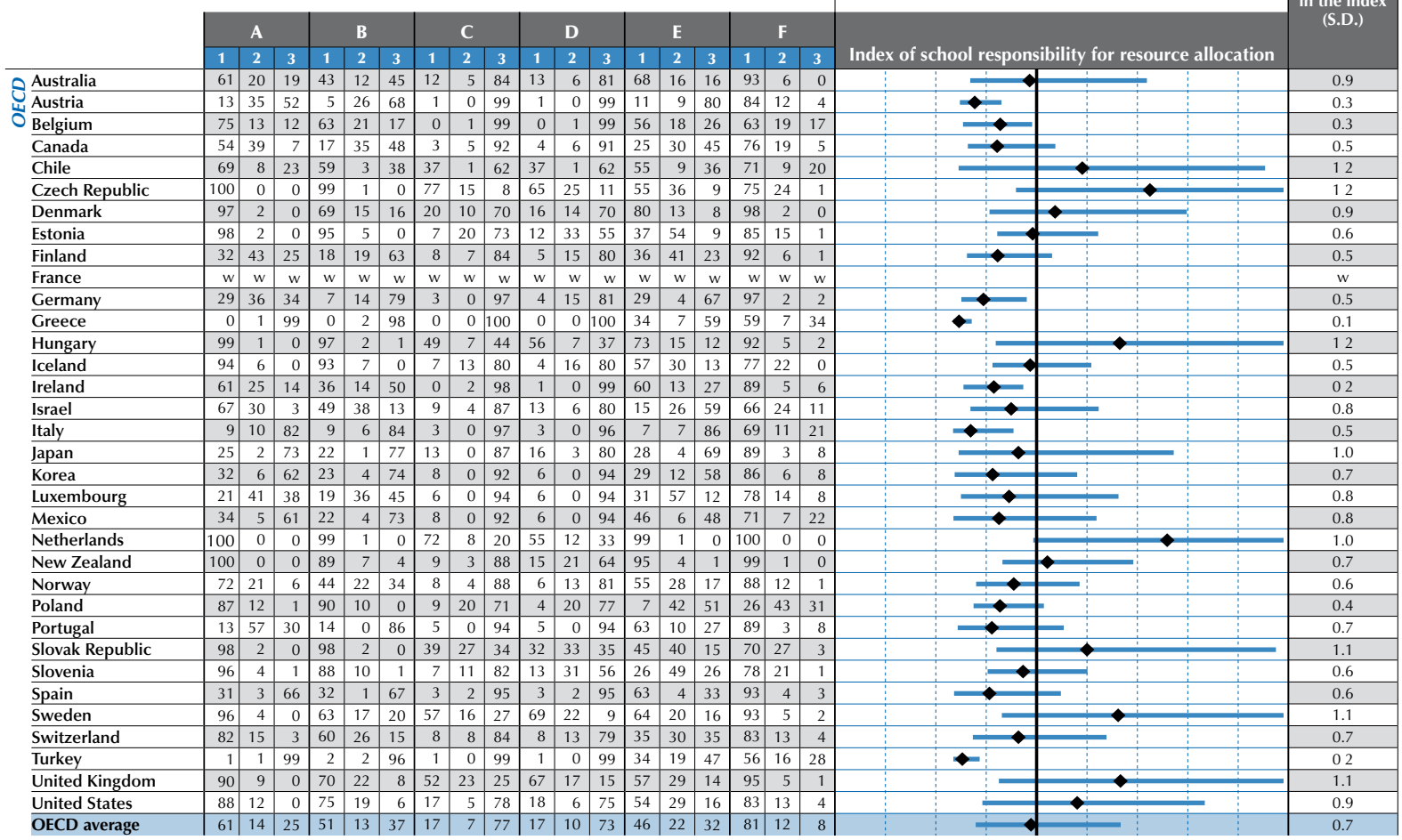

\begin{tabular}{|l|r|r|r|r|r|r|r|r|r|r|r|r|r|r|r|r|r|r|r|}
\hline Albania & 8 & 14 & 78 & 7 & 14 & 79 & 3 & 0 & 97 & 3 & 1 & 96 & 33 & 12 & 55 & 61 & 8 & 31 \\
\hline
\end{tabular}

Argentina

Brazil

Bulgaria

Colombia

Croatia

Dubai (UAE)

Hong Kong-China

Indonesia

Jordan

Kazakhstan

Kyrgyzstan

Latvia

Liechtenstein

Lithuania

Macao-China

Montenegro

Panama

Peru

Peru

Qatar

Russian Federation

Serbia

Shanghai-China

Singapore

Chinese Taipei

Thailand

Trinidad and Tobago

Tunisia

Uruguay

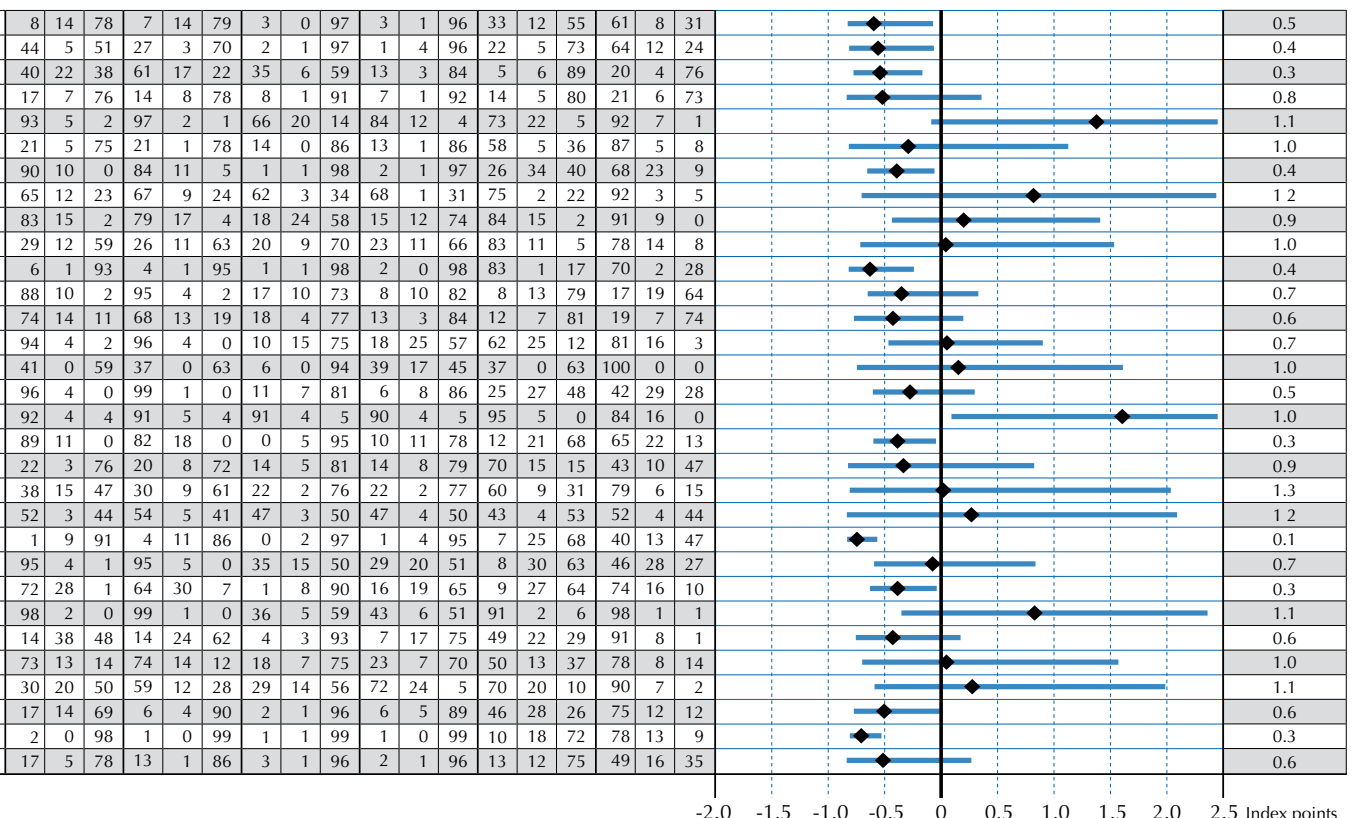

Source: OECD, PISA 2009 Database, Table IV.3.5. 


\section{Figure $2.7(2 / 2)$}

\section{How much autonomy individual schools have over resource allocation}

Percentage of students in schools of 15-year-olds in schools whose principals reported that only "principals and/or teachers", only "regional and/or national education authority" or both "principals and/or teachers" and "regional and/or national education authority" have a considerable responsibility for the following tasks

A Establishing student assessment policies

Choosing which textbooks are used

Determining course content

D Deciding which courses are offered

1 Only "principals and/or teachers"

2 Both "principals and/or teachers" and "regional and/or national education authority"

3 Only "regional and/or national education authority"

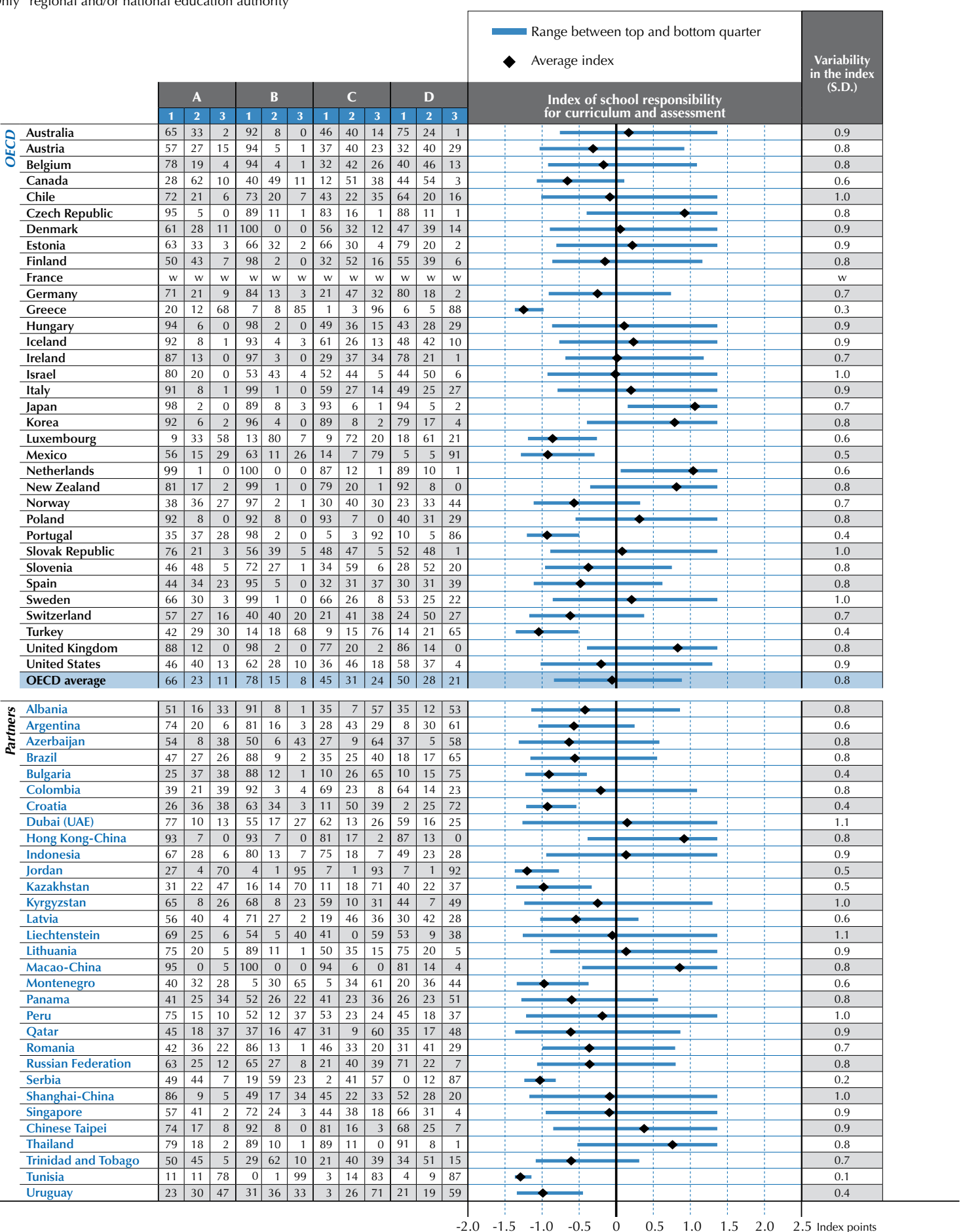


A desire for increased flexibility in the labor market, including to accommodate maternity/ paternity leave, has led to increased part-time employment across many sectors of the economy, among them teaching. On average across OECD countries, about one in six teachers works on a part-time basis in public institutions at primary and lower secondary levels of education. ${ }^{30}$ In some countries, part-time work is common among teachers: between one out of five and one out of three teachers in Australia, the Flemish Community of Belgium, Iceland, and New Zealand work part time, as do more than one-third of teachers in Norway and Sweden, and nearly half the teachers in Germany (primary education) and the Netherlands.

In the majority of OECD countries, part-time employment opportunities depend upon a decision taken at the school level or by local authorities/government; in five of the countries with the largest proportions of part-time employment, the decision is taken at the school level. Schools recognize that their teaching and school organization requirements change; and these countries have some flexibility in their teacher workforce that reflects the changing requirements of the schools.

There is considerable evidence that some beginning teachers, no matter how well prepared and supported, struggle to perform well on the job, or find that the job does not meet their expectations. In a number of countries, a formal probationary process, combined with adequate teacher support, offers an opportunity for both new teachers and their employers to assess whether teaching is the right career for them.

In some countries, the successful completion of probation is acknowledged as a major step in the teaching career. Among 26 countries with comparable data in the OECD's Education at a Glance, 16 countries have a mandatory probation period for teachers. This period usually lasts for one year, but in some countries (Greece, Luxembourg) it lasts for two years, and in Germany it can even be extended to three years. In seven OECD countries, teachers receive job tenure after completing their probationary period. In some countries, such as Austria, six years are necessary to achieve job tenure, whereas there is only a one-month probation period. In some countries a period of time is necessary to hold the tenure, even if there is no probation period. For example, a teacher needs six months to get tenure without any probation period in Mexico, two years to achieve tenure in Iceland, and three years in the Flemish Community of Belgium.

Limited mobility of teachers between schools, and between teaching and other occupations, can restrict the spread of new ideas and approaches, and result in teachers having few opportunities for diverse career experiences. It can also lead to an inequitable distribution of teachers, where teachers do not move from the most favored schools. In some cases the lack of mobility means that some regions of the country might have teacher shortages while others have an oversupply of teachers. In some countries, providing incentives for greater mobility and removing barriers are important policy responses. In countries with different educational jurisdictions, such as federal systems, the mutual recognition of teaching qualifications is crucial, as it ensures that entitlements to leave and retirement benefits move with the teacher. Recognizing the skills and experience gained outside education is also an important means of encouraging greater career mobility among teachers, as is providing flexible re-entry pathways to the profession. International mobility of teachers is also a growing phenomenon, raising issues of recognition of qualifications, certifications and procedures for recruitment and induction. ${ }^{31}$

Given the large number of teachers and applicants involved in most school systems, it is often difficult and costly for employers to use extensive information when selecting candidates. It can be just as difficult for candidates for teaching positions to have precise information about the schools to which they apply, or even about broad trends in the labor market and the available vacancies. Such information gaps and limitations mean that many application and selection decisions are sub-optimal. The development of transparent and prompt systems to close the information gaps between teachers and schools is essential for an effectively functioning teacher labor market, especially where schools are more
Part-time work, which is widespread in many countries, may best be authorized at school level, according to local requirements.

Probationary periods can be crucial in ensuring that suitable people become teachers; but the length of these periods varies greatly across countries.

Education systems could become more dynamic if teachers became more mobile...

$\ldots$ and information flows in the teacher labor market were improved. 
Teacher policy needs to ensure

that teachers work in an environment that facilitates success and that encourages effective teachers to continue in teaching. directly involved in teacher recruitment and selection. Some countries require all teaching vacancies to be posted, and create websites where the information is centralized or establish a network of agencies to co-ordinate and foster recruitment activities. Since imbalances in the teacher labor market can take a long time to be rectified, tools for monitoring and projecting teacher demand and supply under different scenarios can also help.

\section{PROVIDING FOR ATTRACTIVE CAREERS}

Teacher policy needs to ensure that teachers work in an environment that facilitates success and that encourages effective teachers to continue in teaching. There is concern in a number of countries that the rates at which teachers are leaving the profession are compounding school staffing problems and leading to a loss of teaching expertise. Also of concern is that teacher attrition rates tend to be higher in the first few years of teaching, while they decline the longer that teachers are in the profession, before they increase again as teachers approach retirement. ${ }^{32}$ This implies that large private and social costs are being incurred in preparing some people for a profession that they found did not meet their expectations, or that was insufficiently rewarding, or which they found difficult, or some combination of these factors. It underlines the importance for beginning teachers to participate in structured induction programs involving a reduced teaching load, trained mentor teachers in schools, and close partnerships with teacher education institutions, and for school systems to ensure that the criteria and processes used to allocate teachers to schools are designed such that new teachers are not concentrated in the more difficult and unpopular locations.

\section{Box 2.2. Providing greater career diversity in Australia, England and Wales, Ireland and Quebec (Canada)}

In Australia, teachers typically have access to a career structure that involves two to four stages, with annual salary increments within each stage. The stages normally range from beginning teacher to experienced teacher, to experienced teacher with responsibility (leading teacher) or learning area or grade-level co-coordinator, assistant principal, principal, and regional/district office positions. Advancement from one stage to the next, especially at the higher levels, usually requires applying for widely advertised vacancies. As they move up the scale, teachers are expected to have deeper levels of knowledge, demonstrate more sophisticated and effective teaching, take on responsibility for co-curricular aspects of the school, assist colleagues and so on. By "leading teacher" stage, they are expected to demonstrate exemplary teaching, educational leadership, and the ability to initiate and manage change.

In England and Wales, the new career grade of Advanced Skills Teacher (AST), introduced in 1998, is designed to supply an alternative route for career development for teachers who wish to stay in the classroom. Their role is to provide pedagogic leadership within their own and other schools. Typically, they will spend $20 \%$ of their time in an "outreach" role supporting professional development of their colleagues, and teach in class for the remaining time. Teachers can take up an AST post at any point in their career, but in order to do so they must pass the AST assessment. They prepare a portfolio that shows how they meet the prescribed standards for the grade, which is evaluated by an external assessor. The assessor also interviews the applicants and observes their professional practice. In July 2004, some 5000 teachers had passed the AST assessment. The intention is that the grade will ultimately form between $3 \%$ and $5 \%$ of the workforce.

Ireland has introduced four categories of promotion posts: Principal, Deputy Principal, Assistant Principal, and Special Duties Teacher. Each has special management duties and receives both salary and time allowances. In addition to classroom teaching, Assistant Principals and Special Duties Teachers have special responsibility for academic, administrative and pastoral matters, including timetabling arrangements, liaising with parents' associations, supervising the maintenance and availability of school equipment, and so on. They are selected by a panel, which consists of a Principal, chair of the Board of Management, and an independent external assessor. Over the course of their careers, about $50 \%$ of teachers can expect to receive one of these positions. 
In Quebec, experienced teachers can work as mentors for student teachers. Experienced teachers coach and guide the student teachers and undertake specific training. They receive either additional pay or a reduction in classroom teaching responsibilities. About 12000 teachers participate in the mentor program. Some of these experienced teachers also have an opportunity to become co-researchers with university staff and to participate in collaborative studies on subjects such as teaching, learning, classroom management and student success or failure. In addition, experienced teachers may be released from some of their normal duties to provide support for less experienced colleagues.

Although attractive salaries are clearly important for making teaching more appealing and retaining effective teachers, the OECD's Teachers Matter study concludes that policy needs to address more than pay:

- Teachers place considerable emphasis on the quality of their relations with students and colleagues, on feeling supported by school leaders, on good working conditions, and on opportunities to develop their skills. Some countries are therefore placing greater emphasis on teacher evaluations to support improvement in teaching practice. While these evaluations are designed mainly to enhance classroom practice, they create opportunities for teachers' work to be recognized and celebrated, and help both teachers and schools to identify professional development priorities. They can also provide a basis for rewarding teachers for exemplary performance.

- Teaching careers can benefit from greater diversification, which can help meet school needs and also offer more opportunities and recognition for teachers. In most countries, opportunities for promotion and new responsibilities are generally limited for teachers who want to stay in the classroom. Promotions generally involve teachers spending less time in classrooms, and thus diminish one of the major sources of job satisfaction. Even for those who would like to take on more roles outside the classroom, in many countries, those opportunities are limited. Some countries are moving to open more career opportunities for teachers, spurred, in part, by the greater variety of school roles that have been delegated significant decision-making responsibilities. Examples from OECD countries (Box 2.2) suggest that greater career diversity can be achieved by creating new positions associated with specific tasks and roles in addition to classroom teaching, which leads to greater horizontal differentiation; and through a competencybased teaching career ladder that recognizes extra responsibilities, and which leads to greater vertical differentiation. In the latter, each stage is more demanding than the prior stage, involving more responsibilities, and is open to fewer people, but is accompanied by a significant rise in status and, often, compensation. The recognition that schools and teachers need to assume a greater range of tasks and responsibilities also calls for the creation of new roles, such as mentor of beginning and trainee teachers, co-coordinator of in-service education, and school project co-coordinator.

- Greater emphasis on school leadership can help address the need for teachers to feel valued and supported in their work. In addition, well-trained professional and administrative staff can help reduce the burden on teachers, better facilities for staff preparation and planning would help build collegiality, and more flexible working conditions, especially for more experienced teachers, would prevent career-burnout and retain important skills in schools.

As noted before, teachers are largely employed as public servants, and in a number of countries this is associated with tenured employment. While some may consider security of employment as an incentive to become a teacher, there may not be sufficient incentives or support systems for all teachers to continuously review their skills and improve their practice, especially where there are only limited mechanisms for teacher appraisal and accountability. Tenured employment can also make it difficult to adjust teacher numbers when enrolments decline or curricula change, and may mean that the burden of adjustment falls on those who lack tenure, commonly those near the beginning of their careers.
Teaching careers are about more than pay.
Some countries use periodic reviews of teacher certification as an alternative to lifelong tenure... 


\section{Box 2.3. Addressing the scale of professional development}

For the past twenty years, China has been expanding elementary, secondary and higher education at an astonishing rate. Now China is going beyond expansion of access to a focus on quality. So teacher quality is crucial. China has 12 million teachers. Teachers have always been respected in China but China's economic growth has created competition for talent. So teachers are now a major focus of national policy. Over the past few years, major investments in the quality of rural teachers have been made. For example, in 2006 the central government created special three-year posts, paid for by the central government, to enable provinces to hire more teachers. Provinces hired 185000 new teachers and $87 \%$ of them continued after three years.

Under the 2010-20 Education Plan, China is trying to raise the social status of teachers by highlighting their role in economic development. The Plan also calls for raising teachers' salaries to the level of local civil servants and aims to create an atmosphere in which teachers are highly respected. The Ministry of Education is designing a step-by-step process of professional development linked to a career ladder of beginning, medium and high-level teachers. Teachers will have to undertake 360 hours of professional training over five years in order to be recertified. Again, there is a strong focus on teachers in more rural areas. In 2010, 1.1 million teachers will be trained with an emphasis on 23 provinces in central and western China. Upper level students from teachers colleges will do an internship in a rural school that allows a teacher from a rural community to leave for six months of professional development. There is also extensive use of technology to support teachers through a satellite-based transmission of training programs using master teachers. The government is also trying to improve living conditions for teachers in rural areas.

... Which requires an open, fair and transparent system of teacher appraisal, involving teaching peers, school leaders and external experts who are trained and resourced for these tasks.
In some countries teachers need to renew their teacher certificates after a period of time, and often need to demonstrate that they have participated in on-going professional development and coursework to increase, deepen, and strengthen their knowledge. The basis for renewal can be as simple as an attestation that the teacher is continuing to meet standards of performance that are agreed throughout the teaching profession. Such systems must ensure an open, fair and transparent system of teacher appraisal, involving teaching peers, school leaders and external experts who are properly trained and resourced for these tasks - and who are themselves evaluated on a regular basis. Underpinning these models is the view that the interests of students will be better served where teachers achieve employment security by continuing to do a good job, rather than by regulation that effectively guarantees their employment. Periodic reviews are also an opportunity to recognize and acknowledge quality teaching. Some countries have fair but speedy mechanisms to address ineffective teaching. Teachers in these countries have the opportunity and support to improve but, if they do not, they can be moved either into other roles or out of the school system. 


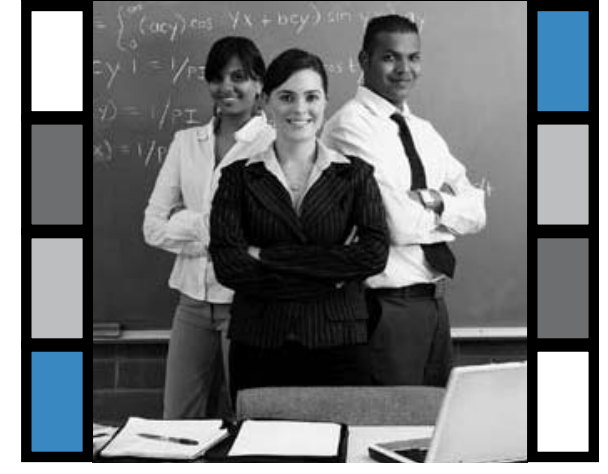

\section{Chapter 3}

\section{TEACHER EVALUATION AND COMPENSATION}

Teacher evaluation is essential for improving the individual performance of teachers and the collective performance of education systems. Designing teacher-appraisal methods is not easy, and requires the objectives of accountability and improvement to be carefully balanced. A crucial feature is what criteria teachers are appraised against, including, but not limited to, student performance. Also important are the degree to which teachers improve their professional skills and, crucially, the part they play in improving the school and system as a whole. In this way, evaluation and appraisal need to be well aligned with the process of system change. However, it is not enough to appraise the right things; the ways in which appraisal is followed through will determine its impact. At present, many teachers feel that appraisal has no or little consequence. School leaders need to become more skilled at using it intelligently, and evaluation needs to be more closely connected with career development and diversity. A specific issue is the extent and style of links between assessed performance, career advancement, and compensation. Whatever system is chosen, it must be well understood and transparently applied. 
Teacher appraisal is advancing from checking whether teachers are doing their job to helping them improve.

New approaches to teacher appraisal seek to improve learning outcomes through fostering and targeting teacher professional development and holding teachers accountable...

...but achieving both these aims simultaneously is challenging...

...and requires careful implementation.

Summit participants reported a wide range of views on approaches to teacher evaluation.

\section{IN SEARCH OF AN EFFECTIVE TEACHER APPRAISAL SYSTEM}

The role of teacher appraisal has changed in recent years. Historically, in most countries it focused on monitoring to ensure adherence to centrally established procedures, policies and practices. In most education systems the focus has now shifted to how teacher appraisal affects learning outcomes (Box 3.2).

Retaining effective teachers implies not only that all teachers have the opportunities, support and incentives to continue to improve and perform at high levels, but also that ineffective teachers do not remain in the profession. Some groups in public discussion want to focus mainly on the latter issue, to the detriment of the image and achievements of the large majority of teachers. Others do not want to acknowledge that this is a real problem.

Effective teacher appraisal can help to improve teachers' practices by identifying strengths and weaknesses for further professional development - the improvement function. This involves helping teachers learn about, reflect on, and adjust their practice. Teacher appraisal can also help to hold teachers accountable for their performance in enhancing student learning - the accountability function. This typically entails performance-based career advancement and/or salaries, bonus pay and, in some countries, the possibility of sanctions for underperformance. It also usually involves evaluating performance at nodal points in a teacher's career.

Combining the improvement and accountability functions into a single teacher-appraisal process raises many challenges, and comparative research on the effectiveness of different models is just beginning to emerge. For example, when evaluation is oriented towards improving practice within schools, teachers are typically willing to reveal their weaknesses, in the expectation that conveying that information will lead to more effective decisions on developmental needs and teacher education. However, when teachers are confronted with potential consequences of evaluation on their career and salary, they are less inclined to reveal weaknesses in their performance, and the improvement function, which builds on trust in the relationship between appraiser and the appraised, may be jeopardized. In practice, countries usually use some combination of these approaches that integrates multiple purposes and methodologies.

Any teacher-appraisal system needs to be implemented with care. This involves reconciling the diverging interests of stakeholders, carefully analyzing policy alternatives and their likely impact, and discussing them with stakeholders to aim towards consensus. Teachers can and do see appraisal and feedback in positive terms. For example, 80\% of teachers in the Teaching and Learning International Survey (TALIS) reported that it was helpful in developing their work as teachers; and almost half of teachers reported that it led to a teacher-development or training plan to improve their teaching. ${ }^{33}$ One way of ensuring that teachers see such evaluation in positive terms is to involve them in school evaluations, in particular by organizing school self-evaluations as a collective process in which teachers take responsibility.

Effective appraisal requires the development of considerable expertise in the system, including training evaluators, establishing evaluation processes and aligning broader school reforms, such as professional development opportunities, with evaluation and assessment strategies. All of these require considerable resources, including time.

It was not surprising that the issue of designing and implementing fair and effective teacher evaluation systems provoked the most controversial discussion at the Summit. The evaluation approaches of countries reported in the Summit vary from structured government-mandated performance management systems like Singapore's (Box 3.4), to school-based systems relying on self and peer appraisal, like Finland's. Denmark reported on a teacher evaluation scheme that $94 \%$ of teachers voted for, which mainly relies on good school leaders to be in classrooms regularly and discussing teaching directly with 
teachers. The Canadian province of Ontario reported on a system with some similarities to Singapore's, with evaluations based on sixteen competencies that are set by a professional college and managed by teachers and principals. New teachers are reviewed twice a year and experienced teachers once every five years, but all teachers have annual learning plans. However, unlike Singapore, Ontario's evaluations are not linked to pay. Some countries, such as Norway and Japan, reported placing great emphasis on the school itself as the unit of evaluation. In Norway, the move towards team teaching means that students are increasingly shared. In Japan, great emphasis is placed on teachers working collaboratively to improve performance. Poland reported about efforts to replace its system of individual teacher appraisals with a system in which school-level evaluations are closely interlinked with individual teacher evaluations. ${ }^{34}$

Figure 3.1

Percentage of teachers without appraisal in the last 18 months

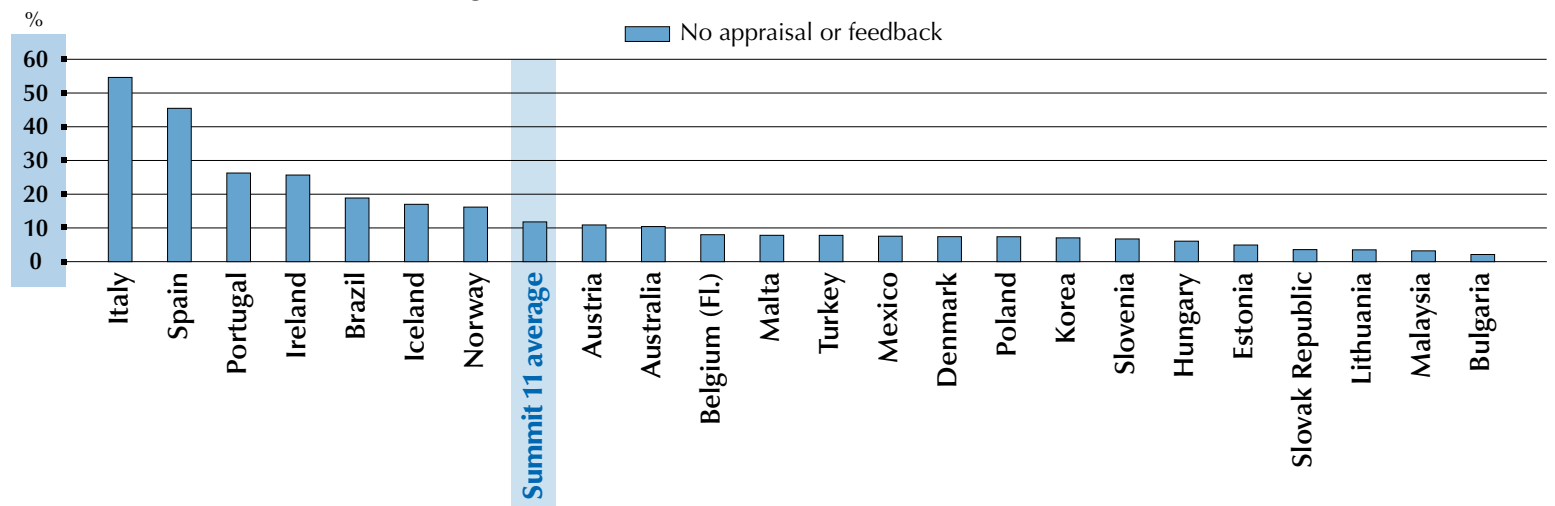

Note: "Summit 11" represents the average figure for the countries that were represented in the International Summit on the Teaching Profession. Countries are ranked in descending order of the percentage of teachers who have received no appraisal or feedback. Source: OECD (2009), Creating Effective Teaching and Learning Environments: First Results from TALIS, Tables 5.1 and 5.3.

As the notes from the Summit suggest, a host of questions were raised - the balance between teacher and school evaluations, the definition of quality and criteria to be used, the need for training for people conducting the evaluations, how to protect against discrimination, the relationship to compensation, and finally, the dangers of distorting an education system by relying on narrow measures of effectiveness..$^{35}$ Some of these issues are discussed in this publication. In order to make progress on any of these fronts, it will be essential for governments and teacher organizations to work together to invent a new vision for the teaching profession. It will also be necessary to move from a conversation among elites to engage a broader dialog with other stakeholders in the system - parents, students, employers. Several participants suggested that information and social media technologies could be used to give broader voice to teachers, parents, students and others who have a stake in the success of the education system.

While improving student learning outcomes is the central objective of teachers' work, the quality of those outcomes is not the only measure of the quality of teaching. Across OECD countries, teachers are judged on a range of criteria, such as:

- teacher qualifications, including teacher credentials, years of service, degrees, certifications and other relevant professional development;

- how teachers operate in the classroom setting, including attitudes, expectations and personal characteristics, as well as strategies, methods and actions employed in their interaction with students; and

- measures of teacher effectiveness, based on an assessment of the degree to which teachers contribute to students' learning outcomes as well as their knowledge of their field and pedagogical practice (Figure 3.2).
The criteria used to evaluate teachers center on learning outcomes, although they also assess significant inputs, such as teacher qualifications and the learning environment created in classrooms... 


\section{Figure 3.2}

\section{Criteria for teacher appraisal and feedback}

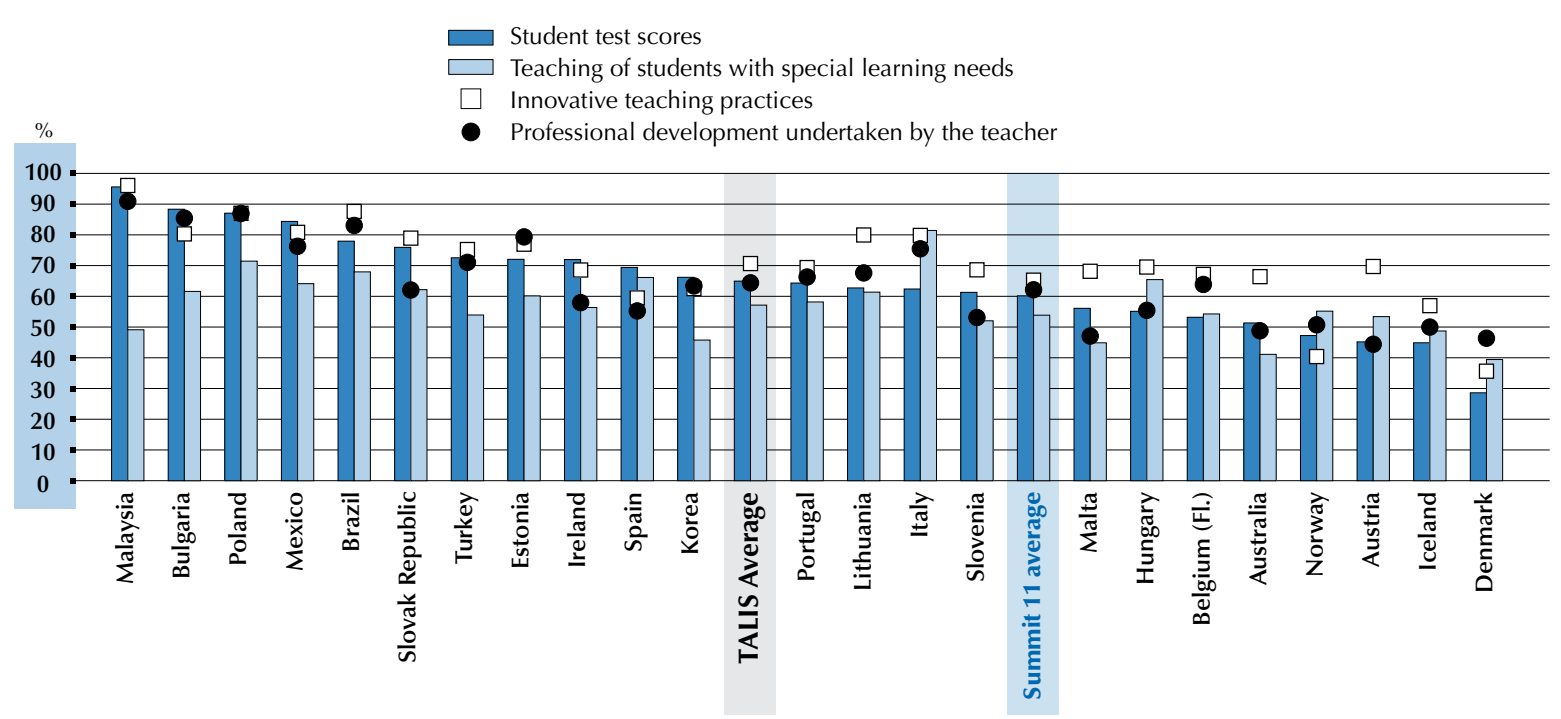

Note: 'Summit 11' represents the average figure for the countries that were represented in the International Summit on the Teaching Profession. Countries are ranked in descending order of the importance of student test scores in teacher apprasial and feedback.

Source: OECD (2009), Creating Effective Teaching and Learning Environments: First Results from TALIS, Table 5.4.

...but the key requirement

is to align appraisals with system objectives and school evaluations.

Appraisal, feedback and evaluation still have limited impact, which could be improved.
Across countries, such criteria are assessed by a variety of instruments, including scores of standardized student assessments, classroom observations, student-generated ratings, peer ratings, school principal and/or administrator ratings, self-evaluations, teacher interviews and portfolios, parental ratings, competence-based tests, and other indirect measures.

These criteria need to be aligned with the objectives of the system and the schools. Aligning criteria for school evaluation with those for teacher appraisal and feedback can emphasize the importance of policy objectives at the school level and give teachers and school principals an incentive to meet such objectives.

\section{MAXIMIZING THE IMPACT OF TEACHER APPRAISAL}

While many countries have innovative teacher-appraisal systems, in some they are still relatively rare or have limited impact. One in five teachers surveyed in TALIS work in schools that had not had a self-evaluation in the past five years, and one in eight received no appraisal of or feedback on their work during the prior 18 months (Figure 3.1). Moreover, only a minority of teachers reported that appraisal and evaluation affects their professional development (one in four), their career advancement (one in six) or their pay (one in ten) (Figure 3.3). Three-quarters reported that they would receive no recognition for improving the quality of their teaching, a similar number said that they would not be rewarded for being innovative, and only just over a quarter reported that teachers would be dismissed because of sustained poor performance (Figure 3.4). These are particularly worrying shortfalls in school systems where teachers are being urged to find creative approaches to teaching in rapidly changing learning environments, yet are more likely to be rewarded for seniority, even if they are underperforming, than for self-improvement or innovation.

This suggests considerable scope for improving the impact of evaluation, appraisal and feedback. Experiences from some countries show that the link between appraisal and improvement can be low-key and low-cost, and that appraisal can include self-evaluation, informal peer evaluation, classroom observation, and structured conversations and regular feedback from the principal and experienced peers. In addition to celebrating quality 
teaching and identifying areas for improvement, appraisals can also provide a basis for rewarding good teachers. Time allowances, sabbatical periods, opportunities for schoolbased research, support for post-graduate study, or opportunities for in-service education are just a few examples of the kinds of rewards for exemplary performance that could be offered if budget constraints do not allow for raises in salaries.

Data from TALIS show that where teachers receive feedback on their work, they are more likely to find it fair than threatening. On average, eight in ten teachers surveyed in TALIS who received feedback thought it was fair, and in all countries but Korea that proportion was more than six in ten. More than three-quarters of teachers also considered it helpful for their work, while the majority said it improved their job satisfaction and development as teachers, without reducing job security. These findings are important, given fears that appraisal and feedback linked to accountability will undermine teachers. Moreover, appraisals can help teachers build confidence in themselves: the more feedback teachers in TALIS received on specific aspects of their work, the more they reported that they trust their own abilities in these areas. They also reported that appraisal leads to changes in the specific aspects of their teaching on which it focuses. In some cases, the focus of appraisal mirrored the areas emphasized in schools' evaluation, facilitating policy makers' efforts to set a framework to influence teachers' work, creating a coherent link between policy priorities and changes in teachers' ${ }^{\prime}$ work and teaching practices. ${ }^{36}$
Improved appraisal and feedback can have beneficial effects on teachers, improving their job satisfaction and personal development as well as their effectiveness in implementing priorities for improvement.

\section{Figure 3.3}

\section{Impact of teacher appraisal on career}

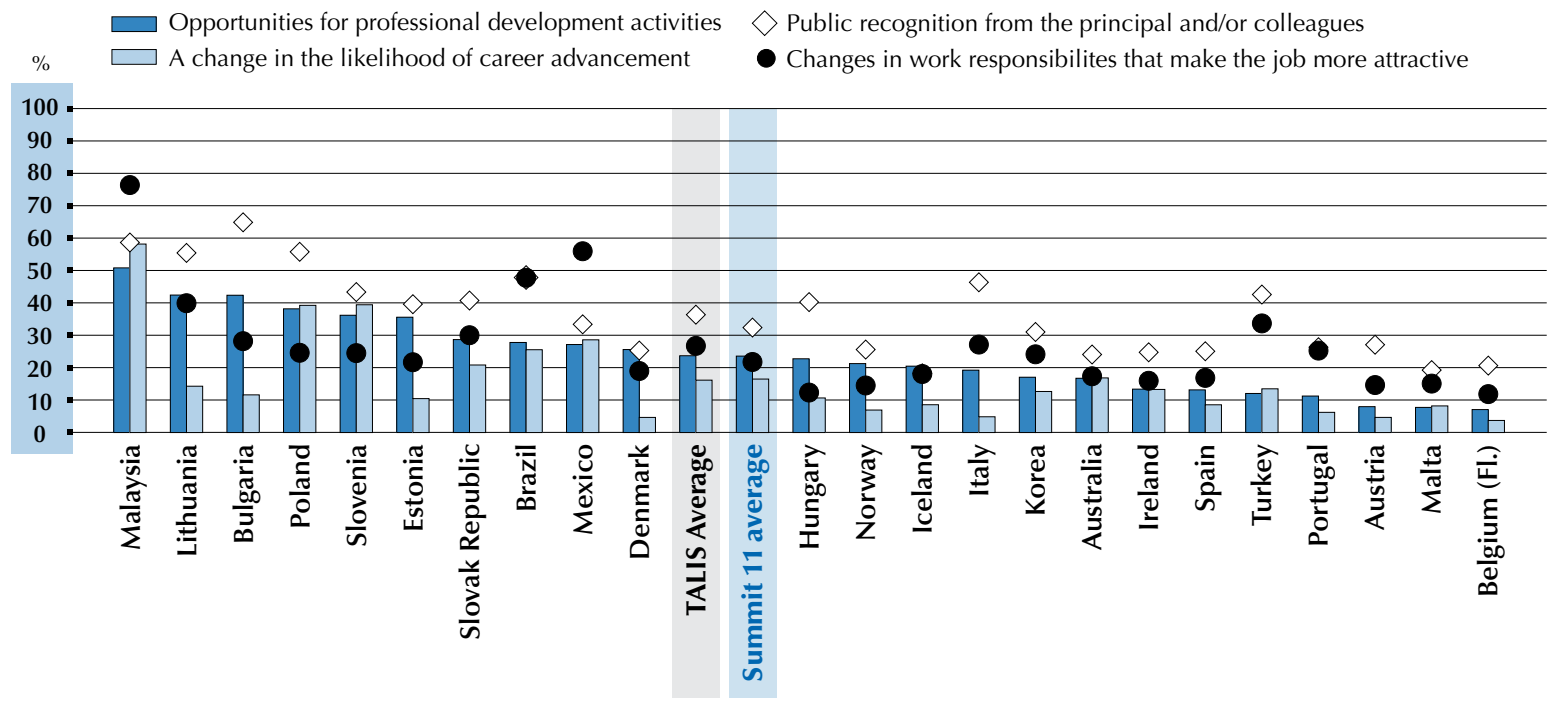

Note: "Summit 11" represents the average figure for the countries that were represented in the International Summit on the Teaching Profession. Countries are ranked in descending order of changes in teachers' opportunities for professional development activities. Source: OECD (2009), Creating Effective Teaching and Learning Environments: First Results from TALIS, Table 5.5.

Strengthening the system of teacher appraisal and feedback can also contribute to developing teaching skills within schools, according to teachers' reports. For example, greater emphasis on the framework for evaluating education in schools can strengthen links between school evaluations and teacher appraisal and feedback. The results of appraisal are often also used to plan the professional development of individual teachers. In turn, closer links with career progression have the benefit of addressing what teachers report as a severe lack of recognition for their development, and the perception that teachers' rewards are not properly linked to their effectiveness (Figure 3.4). 


\section{Figure 3.4}

\section{Consequences of teacher performance as reported by teachers}

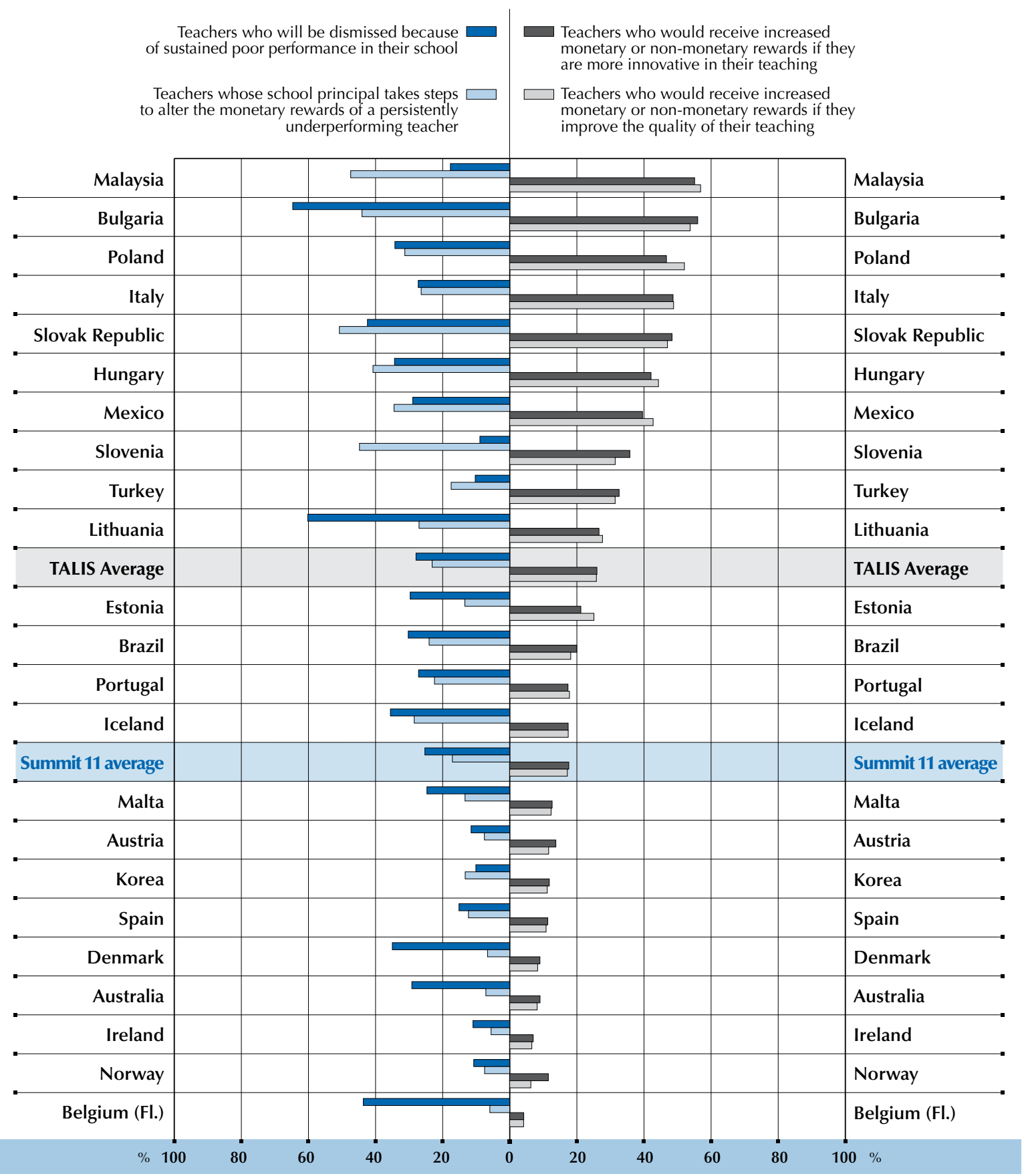

Note: "Summit 11 " represents the average figure for the countries that were represented in the International Summit on the Teaching Profession. Countries are ranked in descending order of percentage of teachers reporting to receive increased monetary or non-monetary rewards for an improvement in the quality of their teaching.

Source: OECD (2009), Creating Effective Teaching and Learning Environments: First Results from TALIS, Table 5.9.

All this shows that it is possible to overcome concerns about appraisal practices if the evaluation culture of schools and school systems is constructive, collaborative and formative. For policy makers, administrators, school principals and teachers, these findings highlight a dual benefit of appraisal and feedback, both to teachers personally and to the development of their teaching. 
Linking recognition and rewards to teacher effectiveness is not just a matter of carrying out appraisals but also of school leaders adopting effective methods for identifying good performance. The fact that nearly four times as many teachers say that their principal does not identify effective teaching as say that they have not recently been appraised indicates the need for follow-through. This underlines the fact that the effectiveness of teacher appraisal critically relies on ensuring that those who design evaluation activities, those who undertake them and those who use their results all have the skills required to do so. In particular, successful feedback mechanisms require those involved to be clear about their responsibilities and to develop the required competencies to carry out these roles.

Thus, competencies for using feedback to improve practice are vital to ensure that evaluation and assessment procedures are effective. Assessment for improving performance requires that actors, such as teachers, are included in the process of school development and improvement. As a result, it is appropriate to include training for evaluation in initial teacher education alongside the development of research skills. Similarly, the preparation to become a school leader is expected to include educational leadership, with some emphasis on feedback mechanisms (Figure 3.5). Particular groups, such as inspectorates, are also in a good position to engage in modeling and disseminating good practice in areas such as school assessment and teacher appraisal.

Teacher reports that appraisal and feedback have contributed to their development suggest that such systems also contribute to school improvement. Appraisal of teachers and subsequent feedback can help stakeholders to improve schools through more informed decision making. Such improvement efforts can be driven by objectives that consider schools as learning organizations that use evaluation to analyze the relationships between inputs, processes and outputs in order to develop practices that build on identified strengths and address weaknesses.

\section{DESIGNING EFFECTIVE COMPENSATION SYSTEMS}

Some Summit participants argued that compensation should not be tied to evaluation, either on principle because it is not fair to put the burden of a dysfunctional school system primarily on teachers - or because of negative side effects. Other countries are working to overcome these concerns and to include some element of financial rewards for performance. And surveys of teachers show that they welcome appraisal and feedback and many report that a good appraisal too often does not lead to any recognition or reward.

As noted in Chapter 1, career advancement opportunities, salaries and working conditions are important for attracting, developing and retaining skilled and high-quality teachers and are intertwined. As teacher salaries represent by far the largest single cost in school education, compensation schemes are a critical consideration for policy makers seeking to maintain both the quality of teaching and a balanced education budget. Decisions on compensation involve trade-offs among related factors, such as ratios of students to teaching staff, class size, instruction time planned for students, and designated number of teaching hours. Data from PISA show that high-performing education systems tend to prioritize the quality of teachers, including through attractive compensation, over other inputs, most notably class size.

In a competitive labor market, the equilibrium rate of salaries paid to teachers across school programs and geographic regions of a country would reflect the supply of and demand for teachers. This is generally not the case in education, as salaries and other working conditions are often set centrally for all teachers - although this has been changing in some countries, notably Sweden, where the government now only sets a minimum starting salary and pay is negotiated between the principal and the teacher (Box 3.1). In most countries, however, teachers' salaries and conditions remain policy-malleable factors that can affect whether the number of qualified teachers meets the needs of the system (Boxes 3.3 and 3.4). As described in Chapter 1, teachers' salary levels vary considerably across countries but tend to remain clearly below other graduates' salaries.
Effective teacher appraisal requires school leaders and others to develop new competencies...

...and good appraisal and feedback can contribute to the improvement of schools as learning organizations.

The most controversial topic discussed at the Summit was whether or not teacher evaluations should be tied to compensation.

Overall teachers' pay varies across countries... 


\section{Figure 3.5}

School principals' views of their involvement in school matters

Index of school principal's leadership based on the reports of school principals of 15-year-old students

I make sure that the professional development activities of teachers are in accordance with the teaching goals of the school. I ensure that teachers work according to the school's educational goals. observe instruction in classrooms.

I use student performance results to develop the school's educational goals.

I give teachers suggestions as to how they can improve their teaching.

I monitor students' work.

When a teacher has problems in his/her classroom, I take the initiative to discuss matters.

I inform teachers about possibilities for updating their knowledge and skills.

I check to see whether classroom activities are in keeping with our educational goals.

I take exam results into account in decisions regarding curriculum development.

I ensure that there is clarity concerning the responsibility for co-ordinating the curriculum.

When a teacher brings up a classroom problem, we solve the problem together.

I pay attention to disruptive behaviour in classrooms.

I take over lessons from teachers who are unexpectedly absent.

Percentage of students in schools whose principals reported that the following activities and behaviours occurred "quite often" or "very often" during the last school year

\begin{tabular}{|c|c|c|c|c|c|c|c|c|c|c|c|c|c|c|}
\hline & A & B & C & D & E & $F$ & G & H & I & J & $\mathrm{K}$ & L. & M & $\mathbf{N}$ \\
\hline Australia & 98 & 99 & 64 & 93 & 76 & 58 & 89 & 95 & 81 & 81 & 97 & 93 & 94 & \\
\hline Austria & 89 & 92 & 41 & 60 & 67 & 86 & 84 & 79 & 67 & 22 & 75 & 92 & 87 & 53 \\
\hline Belgium & 95 & 97 & 43 & 42 & 68 & 33 & 89 & 90 & 82 & 46 & 74 & 98 & 96 & 4 \\
\hline Canada & 98 & 98 & 77 & 91 & 86 & 60 & 95 & 95 & 86 & 63 & 87 & 99 & 98 & 19 \\
\hline Chile & 97 & 98 & 55 & 93 & 95 & 73 & 90 & 96 & 82 & 84 & 94 & 97 & 97 & 62 \\
\hline Czech Republic & 95 & 98 & 57 & 81 & 79 & 93 & 86 & 98 & 83 & 59 & 93 & 96 & 75 & 23 \\
\hline Denmark & 86 & 89 & 25 & 44 & 53 & 39 & 94 & 91 & 76 & 25 & 76 & 99 & 95 & 29 \\
\hline Estonia & 92 & 94 & 59 & 84 & 58 & 75 & 72 & 93 & 57 & 62 & 87 & 83 & 79 & 24 \\
\hline Finland & 64 & 75 & 9 & 46 & 40 & 61 & 77 & 95 & 59 & 13 & 77 & 98 & 94 & 39 \\
\hline Franc & $\mathrm{w}$ & $\mathrm{w}$ & $w$ & $\mathrm{w}$ & $w$ & $\mathrm{w}$ & $\mathrm{w}$ & $\mathrm{w}$ & $\mathrm{w}$ & $\mathrm{w}$ & w & $\mathrm{w}$ & $\mathrm{w}$ & \\
\hline Germ & 82 & 94 & 40 & 57 & 53 & 82 & 80 & 85 & 57 & 33 & 73 & 95 & 84 & 42 \\
\hline Greece & 40 & 78 & 12 & 61 & 53 & 46 & 97 & 96 & 67 & 34 & 69 & 98 & 96 & 63 \\
\hline ry & 93 & 99 & 54 & 84 & 62 & 84 & 89 & 91 & 65 & 73 & 86 & 94 & 91 & 41 \\
\hline & 88 & 89 & 39 & 78 & 77 & 69 & 87 & 96 & 54 & 58 & 87 & 100 & 75 & 26 \\
\hline Ireland & 88 & 88 & 14 & 64 & 41 & 50 & 88 & 92 & 62 & 78 & 88 & 97 & 97 & 39 \\
\hline Israel & 94 & 99 & 46 & 87 & 85 & 81 & 94 & 89 & 86 & 90 & 94 & 97 & 98 & 26 \\
\hline Italy & 97 & 99 & 39 & 86 & 75 & 87 & 96 & 98 & 88 & 77 & 92 & 98 & 98 & 18 \\
\hline Japan & 43 & 51 & 37 & 30 & 38 & 40 & 29 & 50 & 31 & 37 & 29 & 61 & 60 & 17 \\
\hline Korea & 80 & 85 & 42 & 64 & 68 & 56 & 75 & 69 & 60 & 46 & 63 & 79 & 68 & \\
\hline Luxembourg & 87 & 98 & 32 & 65 & 52 & 64 & 96 & 67 & 74 & 32 & 47 & 98 & 98 & 23 \\
\hline Mexic & 95 & 97 & 68 & 94 & 89 & 90 & 95 & 91 & 92 & 62 & 90 & 97 & 96 & 43 \\
\hline Net & 95 & 97 & 52 & 66 & 73 & 50 & 76 & 82 & 79 & 75 & 80 & 86 & 71 & 16 \\
\hline New Zeala & 99 & 98 & 68 & 98 & 73 & 42 & 78 & 84 & 74 & 87 & 97 & 83 & 94 & 12 \\
\hline Norway & 81 & 88 & 24 & 70 & 49 & 55 & 90 & 91 & 48 & 47 & 81 & 98 & 95 & 28 \\
\hline Poland & 94 & 97 & 93 & 95 & 89 & 96 & 91 & 99 & 92 & 71 & 80 & 97 & 93 & 37 \\
\hline Portugal & 93 & 97 & 9 & 94 & 65 & 49 & 91 & 89 & 48 & 82 & 97 & 99 & 97 & 7 \\
\hline Slovak Republic & 97 & 99 & 86 & 87 & 86 & 90 & 86 & 98 & 91 & 76 & 96 & 91 & 91 & 15 \\
\hline Slovenia & 99 & 100 & 77 & 78 & 85 & 90 & 90 & 95 & 85 & 65 & 93 & 98 & 94 & 23 \\
\hline Spain & 86 & 97 & 28 & 85 & 55 & 45 & 86 & 86 & 66 & 71 & 92 & 99 & 99 & 63 \\
\hline & 90 & 96 & 38 & 83 & 63 & 29 & 89 & 90 & 52 & 68 & 93 & 98 & 87 & 13 \\
\hline & 72 & 82 & 64 & 34 & 60 & 61 & 85 & 80 & 59 & 17 & 54 & 92 & 83 & 31 \\
\hline & 85 & 95 & 70 & 93 & 85 & 90 & 75 & 90 & 87 & 78 & 93 & 97 & 99 & 36 \\
\hline & 100 & 100 & 93 & 100 & 92 & 88 & 90 & 96 & 95 & 97 & 99 & 96 & 97 & 29 \\
\hline & 98 & \begin{tabular}{|c|}
98 \\
\end{tabular} & 95 & 96 & 94 & 72 & 95 & 97 & 94 & 88 & 90 & 97 & 96 & 16 \\
\hline OECD average & 88 & \begin{tabular}{|c|}
93 \\
\end{tabular} & 50 & 75 & 69 & 66 & 86 & \begin{tabular}{|c|}
89 \\
\end{tabular} & 72 & 61 & 82 & 94 & 90 & 29 \\
\hline
\end{tabular}
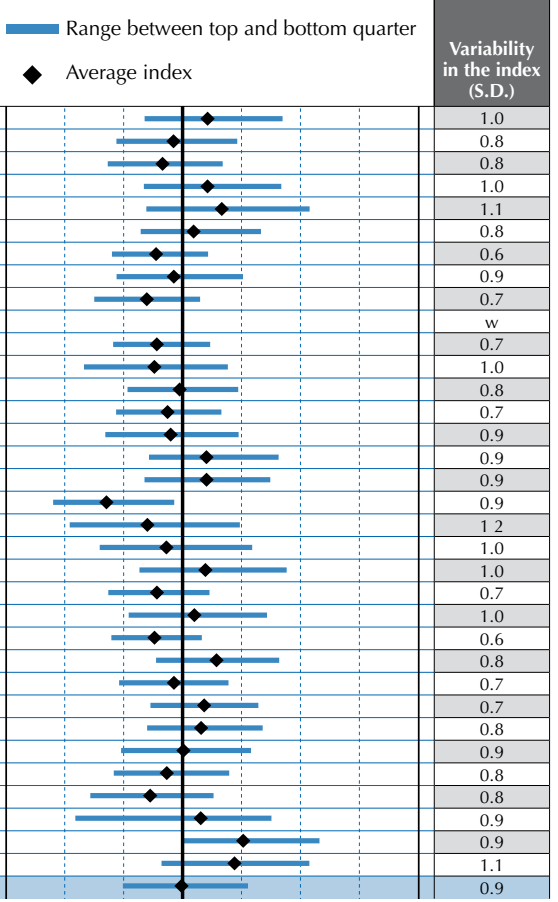

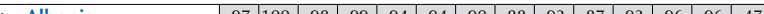

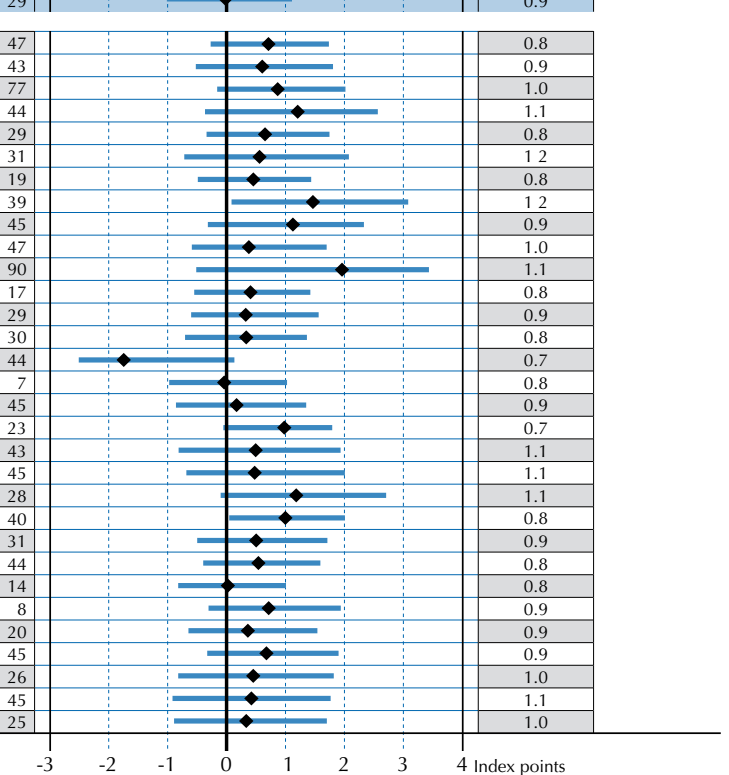

Note: Higher values on the index indicate greater involvement of school principals in school matters.

Source: OECD, PISA 2009 Database, Table IV.4.8. 


\section{Box 3.1. Individual pay in Sweden}

\section{In Sweden, pay is now negotiated between the principal and the teacher.}

One of the most radical approaches to compensation systems has been implemented in Sweden, where the federal government establishes minimum starting salaries and leaves the decisions about individual teachers' salaries to be negotiated annually by the principal and the teacher. If the teacher requests assistance, the teachers' union can participate in the negotiation. In Sweden, the centrally bargained fixed-pay scheme for teachers was abolished in 1995 as part of a package designed to enhance local autonomy and flexibility in the school system. The government committed itself to raising teachers' salaries substantially over a five-year period, but on the condition that not all teachers received the same raise. This means that there is no fixed upper limit and only a minimum basic salary is centrally negotiated, along with the aggregate rise in the teacher-salary bill. Salaries are negotiated when a teacher is hired, and teacher and employer agree on the salary to be paid at the beginning of the term of employment. The individual negotiation involves: (1) teachers' qualification areas: teachers in upper secondary schools have higher salaries than teachers in compulsory schools or teachers in pre-schools; (2) the labor market situation: in regions where teacher shortages are more acute, teachers get higher salaries; the same occurs for certain subjects like mathematics or science; (3) the performance of the teacher: the collective central agreement requires that pay raises be linked to improved performance, allowing schools to differentiate the pay of teachers with similar tasks; and (4) the range of responsibilities of teachers: principals can reward teachers if they work harder and take up more tasks than generally expected.

There is now much greater variety in teachers' pay in Sweden, with those teachers in areas of shortage and with higher demonstrated performance able to negotiate a higher salary. The scheme is underpinned by a system of central government grants to ensure that low-income municipalities are able to compete effectively for teachers and other staff in the service sectors of the municipality. Sweden, with its individual teacher pay system introduced in 1995, provides an interesting example of a country that has attempted to combine a strong tradition of teacher unionism and consultative processes with opportunities for flexible responses and non-standardized working conditions at the school level. The system was at first strongly contested by unions and teacher organizations, but now enjoys an over $70 \%$ approval rate among unionized teachers.

\section{Box 3.2. Identifying and certifying outstanding teachers}

\section{In the United States, the National Board for Professional Teaching Standards has established standards.}

The National Board for Professional Teaching Standards (NBPTS) was created in 1987, on the recommendation of the Carnegie Task Force on Teaching as a Profession, to "establish high and rigorous standards for what accomplished teachers should know and be able to do". The goal of Board Certification, modeled on that in other professions, was to identify and certify outstanding teachers, provide a framework for teacher professional development and create a system through which outstanding teachers could receive salary supplements and be available for new roles in schools. The Board was developed with the active support of the American Federation of Teachers and the National Education Association and now has certificates in 25 fields, defined by subject matter and developmental level. Teachers complete ten assessments over a period of more than a year, including portfolios of student work, videos of classroom practices, examples of impact on student learning, review by peers, expert evaluations, and assessments of subject-matter knowledge. Today, more than 90000 teachers have taken National Board Certification. Thirty-two states and more than 700 districts offer fee support or salary supplements. A Congressionally mandated review of studies of the effectiveness of NBPTS teachers found teachers who earned NBPTS certification tended to be more effective than teachers who had not earned NBPTS certification, although it did not establish a causal relationship. It concluded that existing research "neither proves nor refutes" the idea that pursuing NBPTS certification leads to improvements in effectiveness. A number of other countries are now looking at the NBPTS standards and processes as a potential model. 


\section{Box 3.3. Linking pay to work}

In Denver, Colorado, teachers get additional pay linked to factors such as professional improvement, good evaluation and student progress.

Denver's Professional Compensation (ProComp) system was initially developed by a joint task force of district, union and community representatives. This work began in 2002, and the group's proposal was accepted by a vote of teachers in 2004 . The program began with local funding, and then started to receive federal funds under the Teacher Incentive Fund program in 2006. As part of the ProComp system, teachers receive additional compensation based on several factors, including (1) teacher knowledge and skills, as obtained through targeted professional development; (2) high evaluation ratings; (3) teaching in high-need schools and subjects; and (4) demonstrated student growth, both at the classroom and the whole-school level. District and union leadership report ongoing collaboration both to improve the ProComp system and to improve results in the district in general. A recent study published by the University of Colorado at Boulder found a strong impact on student achievement, with improvements in teacher effectiveness leading to improved learning outcomes and increases in teacher retention. The federal government continues to support innovative approaches to teacher evaluation, compensation, professional development, and career advancement through the recently expanded Teacher Incentive Fund program.

...as does the structure of salary rewards, especially in terms of how salaries increase in the course of a career...
Comparing salary levels at different points in a career indicates how pay progresses through teachers' careers. Some countries concentrate salary increases early in the career, some save higher rewards for more experienced employees, while for others progress is steady throughout a career. ${ }^{37}$ There is some evidence that a sizeable proportion of teachers and school administrators do not want to move into higher positions in the hierarchy in schools, such as school principal. This may be because the negative aspects of a promotion outweigh positive aspects, such as increased salaries, prestige and other rewards. If this is the case, then the promotion can be made more attractive either by changing the duties and requirements of the position or by changing the salary and other rewards.

Deferred compensation is a key incentive for workers in many industries. This rewards employees for staying in organizations or professions and for meeting established performance criteria. Some form of deferred compensation exists in the teachers' salary structures of most countries. In OECD countries, statutory salaries for primary, lower and upper secondary general teachers with 15 years of experience are, on average, 38\%, 39\% and 43\% higher, respectively, than starting salaries. Furthermore, the increases from starting salary to the top of the salary scale are, on average, $71 \%, 70 \%$ and $74 \%$, respectively (see also Annex A). ${ }^{38}$

The number of years it takes for a teacher to advance through the salary scale also varies substantially across countries. In lower secondary education, teachers in Australia, Estonia, Denmark, New Zealand and Scotland reach the highest step on the salary scale within six to nine years. Monetary incentives therefore disappear relatively quickly compared to other countries. If job satisfaction and performance are determined, at least in part, by prospects of salary increases, difficulties may arise as teachers approach the peak in their age-earnings profiles.

A number of countries have both steep and flat rises in teachers' salaries that vary across teachers' tenure. For example, teachers in Germany and Luxembourg have an opportunity for similar salary increases in the first 15 years, but then face very different growth rates. In Luxembourg salaries rise faster, while in Germany increases are relatively small. Policy makers in these countries thus need to consider how to retain the more experienced teachers.

In addition to basic pay scales, school systems increasingly offer additional payments or other rewards for teachers (Figure 3.6). These may take the form of financial remuneration and/or reduction in the number of teaching hours. In some cases, such as in Greece and Iceland, long service is rewarded by reductions in teaching hours. In Portugal, teachers 
may receive a salary increase and a reduction in teaching time during the time they carry out special tasks or activities, such as educating student teachers, guidance counseling, etc. Together with the starting salary, such payments may affect a person's decision to enter or stay in the teaching profession. Additional payments early in a career may include family allowances and bonuses for working in certain locations, and higher initial salaries for higher-than-minimum teaching certification or qualifications, such as qualifications in multiple subjects or certification to teach students with special educational needs. Data on additional payments ${ }^{39}$ fall into three broad areas:

- those based on responsibilities assumed by teachers and on particular conditions (e.g. additional management responsibilities or teaching in high-need regions, or disadvantaged schools);

- those based on the family status or demographic characteristics; and

- those based on teachers' qualifications, teacher education and performance (e.g. higher than the minimum qualifications and/or completing professional development activities).

Figure $3.6(1 / 2)$

Criteria for additional payments in public institutions

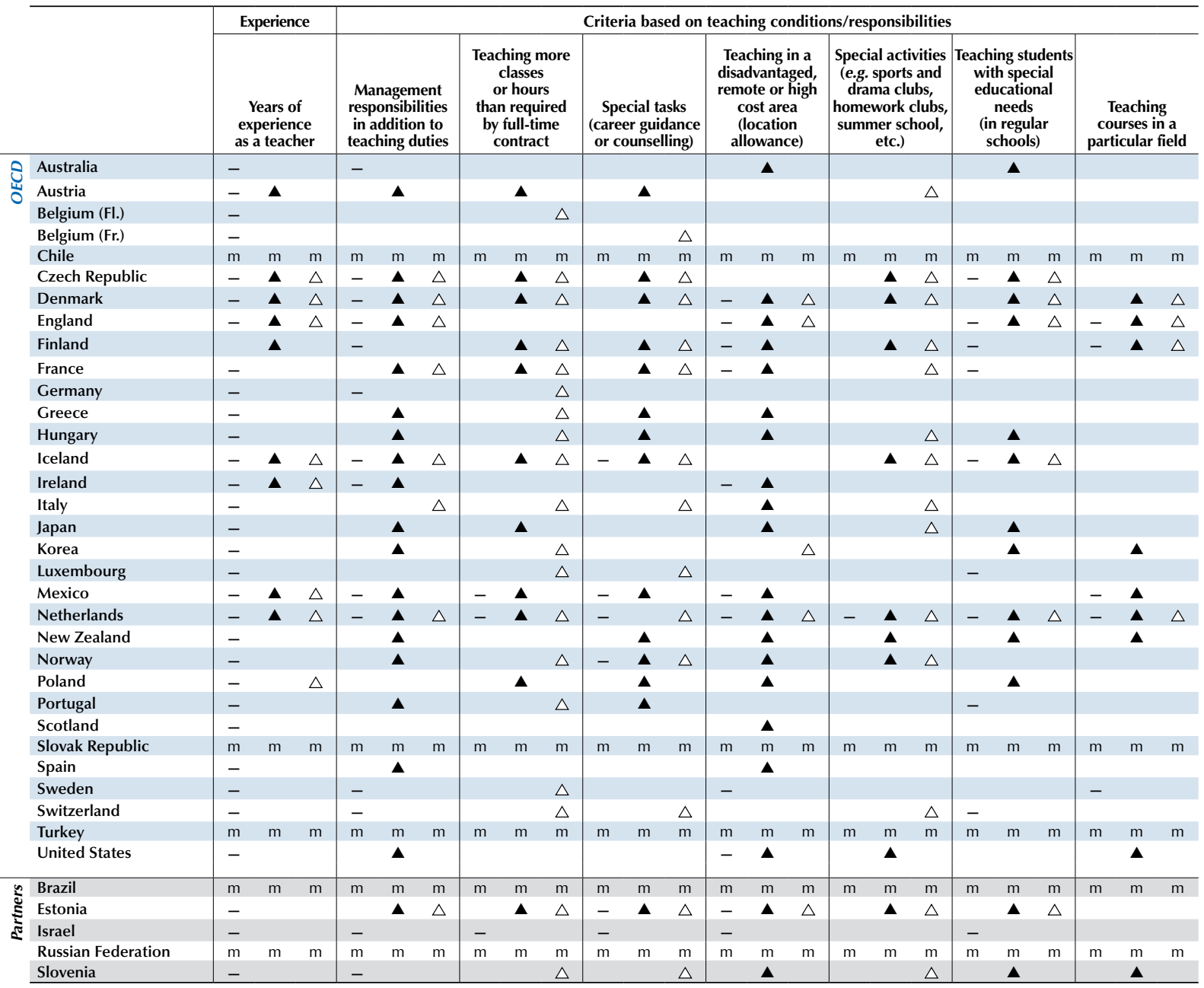

: Decisions on position in base salary scale

A : Decisions on supplemental payments which are paid every year

$\triangle$ : Decisions on supplemental incidental payments

Source: OECD (2010), Education at a Glance 2010: OECD Indicators. See Annex 3 for notes (www.oecd.org/edu/eag2010).

Please refer to the Reader's Guide in Education at a Glance 2010 for information concerning the symbols replacing missing data. 
Figure $3.6(2 / 2)$

\section{Criteria for additional payments in public institutions}

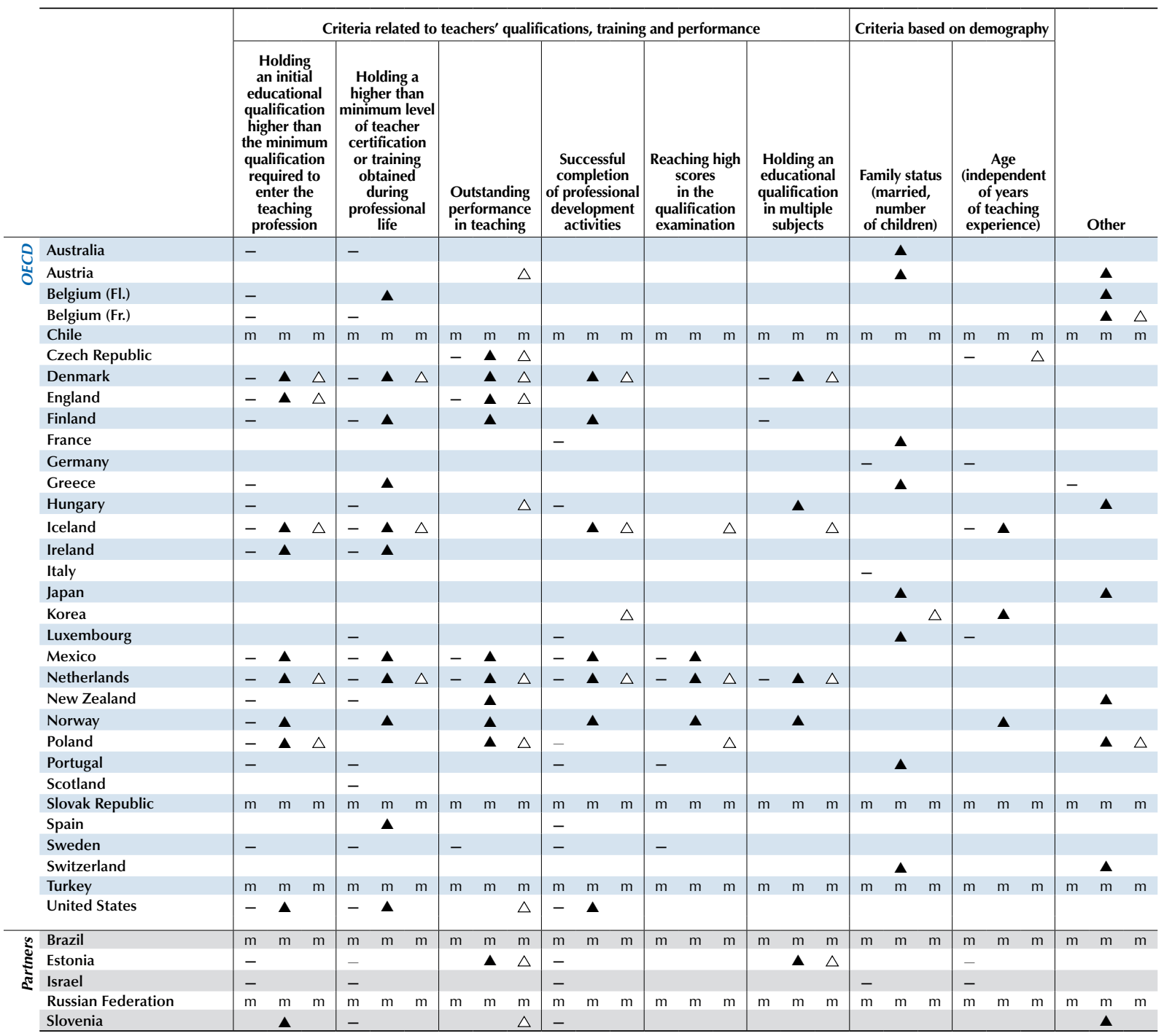

_ : Decisions on position in base salary scale

$\Delta$ : Decisions on supplemental payments which are paid every year

$\triangle$ : Decisions on supplemental incidental payments

Source: OECD (2010), Education at a Glance 2010: OECD Indicators. See Annex 3 for notes (www.oecd.org/edu/eag2010).

Please refer to the Reader's Guide in Education at a Glance 2010 for information concerning the symbols replacing missing data.

Less than half of OECD countries offer additional payments based on teachers' family status or demographic characteristics, and in most cases these are yearly payments.

Many countries offer additional payments based on teachers' qualifications, professional development and performance. The most common types of payments based on teachers' initial education and qualifications are for an initial education qualification higher than the minimum requirement and/or a level of teacher certification and teacher education higher than the minimum requirements. These are available in around two-thirds of OECD countries, with half of countries offering both types. They are used in nearly all countries as criteria for base salary. Eighteen countries offer additional payments for the successful completion of professional-development activities. In some countries, adjustments to the base salary are awarded to teachers annually or on an incidental basis, either by the head 
teacher or school principal, or by the local, regional or national government. Countries vary in whether they provide such payments as an addition to teachers' base salary, in the form of a yearly payment or on an incidental, or "one-off", basis.

Thirteen OECD countries and two non-OECD countries with available data offer an additional payment for outstanding performance in teaching. In two-third of these countries, these are discretionary payments, and in ten, they are mostly annual additions to teachers' salaries. It is notable that in 13 of the 15 countries with available data that offer this incentive - Austria, the Czech Republic, Denmark, England, Estonia, Finland, Hungary, Mexico, the Netherlands, New Zealand, Poland, Slovenia and Sweden - the decision to award the additional payments can be made at the school level. Formal metrics, including student-achievement data, come into play in some countries, but most decisions are based on the nuanced judgments of professional colleagues who, in turn, base their opinions on multiple sources of data, only some of which are measured in any formal way.

Performance-based reward systems in OECD countries can be classified into three types: "Performance pay", which generally involves measuring teacher performance based on student outcomes and other measures and providing strong performers with higher pay and, in some cases, advancement opportunities; "Knowledge and skill-based" compensation, which generally involves higher pay for demonstrated knowledge and skills which are believed to enhance student performance; and "School-based compensation", which generally involves group-based financial rewards. Those who argue in support of performance-based rewards say that it is fairer to reward teachers who perform well rather than paying all equally; performance-based pay motivates teachers and improves student performance; and a clearer connection between spending on schools and student performance builds public support. Those who oppose performance-based pay usually argue that fair and accurate evaluation is difficult, because performance cannot be determined objectively; co-operation among teachers is reduced; teachers are not motivated by financial rewards; teaching becomes narrowly focused on the criteria being used; and the costs of implementation are too high. Research in this field is difficult and there are few reliable studies.

Though experience with performance-based rewards systems in OECD countries is still limited, OECD research highlights a number of common design around what to reward, whom to reward and how to structure rewards. ${ }^{40}$

Performance-based rewards imply rewarding something more than credentials and years of experience, which have been shown to be weak indicators of teacher effectiveness. Research has shown that it is possible to evaluate effective teaching, linked with improved student results, thus making it possible, in principle, to include evaluations both of teacher performance and student performance as part of a teacher-compensation system. Whatever criteria are chosen, they need to be clear to teachers and consistently applied.

Measures of teacher performance need to be valid, reliable and agreed by teachers themselves to be fair and accurate. In some countries, these include assessments of teacher performance that are based on multiple observations by trained evaluators using a standards-based rubric that teachers believe reflects good instructional practices. Other measures of teacher performance may include contributions to school-improvement efforts or performance in specific areas based on external certifications.

Some approaches include student performance in the reward systems for teachers, which require robust data management systems that are able to connect student and teacher data. In particular, if "value-added" measures are used, databases need to be able to track student progress from year to year, to give an indication of what any individual teacher has added to a student's attainment. The Data Quality Campaign identifies a number of data requirements for such approaches. ${ }^{41}$ Measures of student performance include test scores, enrolment in advanced courses, student attendance, student graduation rates, and student dropout rates.
Developing a closer relationship between teacher performance and compensation has proved difficult.
The experience so far with performance-based rewards raises issues about how to design such awards, including issues relating to what to reward.. 
Analysis of student work can provide a further measure of student performance, but it requires time and funding for a group of trained assessors to evaluate portfolios of student work and determine evidence of growth. If the tests are to be used to determine value-added progress that students have made (i.e. using statistical methods to analyze a student's current scores in light of past performance to get an accurate reading of the effect of the school/teacher on the student's performance), then tests needs to be designed to enable analyses of year-to-year gains in performance at the individual student level.

\section{Box 3.4. A comprehensive approach to teacher appraisal and compensation in Singapore}

Singapore takes steps to ensure that high-quality graduates can start their careers on salaries competitive with other professions, and follows through with a coherent and comprehensive system of teacher appraisal and progression.

Singapore has established a coherent and comprehensive system of teacher appraisal and progression. To this end, it uses a combination of incentives throughout the teacher's career, aligned to the goals of the system, that enable it to select and sustain effective teachers. The system has been developed over time and refinements have been added as new issues or conditions have arisen.

Once in the Singapore teaching corps, annual evaluations offer the possibility of performance bonuses of $10 \%-30 \%$ of base salary. Included in Singapore's Enhanced Performance Management System is an appraisal of teachers' contribution to the academic and character development of the students in their charge, their collaboration with parents and community groups, and their contribution to their colleagues' development and to the school as a whole. The Enhanced Performance Management System is not intended to digitally calibrate teacher ability or to rank teachers. It is intended as a holistic appraisal, devised at the national level but implemented and customized at the school level. It assesses teachers against key competencies including the role of the teacher in the academic and character development of their students, the pedagogic initiatives and innovations teachers have developed, the professional development they have undertaken, their contribution to their colleagues and the school, and their relationship to community organizations and to parents. Learning outcomes are defined broadly, not just by examination results. The evaluation is conducted by several professionals in the school including department heads and the principal. The standards for the evaluation were developed ten years ago as a pilot with cooperation of and input from teachers and have been refined over time as new issues and conditions develop.

The purpose of the evaluation process is to create a regular dialog between teacher and supervisor that is frequent, clear and detailed about how to improve teachers' practice. Teachers create a plan at the beginning of a year, which is reviewed and followed by mid-year and year-end reviews. It is intended primarily as a development tool. Areas of weakness become the focus of the teachers' professional development plan for the following year. It is also intended to help teachers keep up with change. Fidelity of execution and open dialog is important. The process is time-consuming but it takes a lot of effort to get people into the profession and developing a competent teacher is seen as a lifelong undertaking.

Teachers who do outstanding work receive a bonus from the school's bonus pool. The evaluations also pinpoint areas of needed improvement that form the basis of the personal professional development plan for the following year. All teachers have access to 100 hours of professional development each year, at no cost to the teacher, which they can use to make progress on their personal development plans. Poorly performing teachers are offered assistance to improve and are dismissed if they do not.

In addition, teachers receive annual reimbursements for improving their knowledge and skills through professional development, subscriptions to professional journals, language learning, or technology training. Teachers move along a series of career steps that include greater compensation for greater responsibility and contributions to the profession and the school. And to keep effective teachers in the profession, there are attractive retirement payments.

While the Singapore system includes many interesting components, it is the coherence of the whole system that is important. Because Singapore has a single system and teachers are centrally assigned, market factors within the system are not the issue they are in other countries. There are also no "hard-to-staff" schools because teachers are assigned where they are most needed, resulting in a mix of less and more experienced teachers in every school. 
A major issue is whether the rewards are targeted to individual teachers, groups of teachers or the whole school. Each approach has advantages and disadvantages.

Individual rewards can both select the most effective staff and motivate individuals to work harder, giving them a sense of direct control over their chances of reward. However, it can be difficult to distinguish the impact made by an individual teacher, compared to previous teachers or other factors such as the school environment.

An alternative is to consider the performance of a group of teachers as a unit - such as a grade-level teams, a disciplinary departments, or another grouping that fits a school's structure and mission. Group rewards have been found to promote staff cohesion, feelings of fairness and productivity norms, and they may foster the transfer of knowledge and mutual learning among teachers which can lead to improved results. School-wide rewards can encourage collaboration among teachers to ensure the school meets the criteria for rewards, but they may have disadvantages, such as diluting the link between individual effort and reward. Any group approach runs the risk of "free riders", but some systems seek to limit these by keeping groups small or by establishing programs to exert social pressure as well as to monitor peer contributions to the group's performance. Another consideration is whether to reward other staff than classroom teachers. Principals and assistant principals may not teach, but their work is critical to establishing an environment that is conducive to improving student achievement.

Systems also differ in whether they structure the payout of rewards as a fixed global sum distributed according to ranked teacher performance (for example, a bonus for the top quarter of performers) or as a bonus for any teacher reaching a fixed level of teacher performance. The first has the advantage of establishing at the outset the maximum amount of money that a district or country will spend but, as noted above, may discourage effort among those who do not think they can outperform their colleagues. This disincentive can, however, be reduced where the assessment of teachers or schools takes account of contextual factors, such as socio-economic background or prior attainment, by giving teachers with the most challenging students a prospect of scoring relatively well.

The alternative of giving fixed rewards to schools or teachers meeting a specified performance level needs to specify clearly what teachers need to do to meet this requirement. It opens the possibility of earning a reward to more teachers and encourages them to develop their skills and work more effectively; but it potentially raises the amount of money that must be set aside to fund the rewards, allowing for the possibility of most or all teachers earning the bonus. To renege on the payment of rewards to teachers will doom a reward program, as teachers will question the commitment to improvement that it represents. The decision between rank-order and fixed-performance criteria as a basis for performance pay may depend on the resources available, although a system may choose to use a combination of the two.
...Whom to reward, and...

...how to structure awards.

\section{Box 3.5. Towards the next TALIS survey}

Building on the success of the first Teaching and Learning International Survey (TALIS) thirty countries are currently collaborating to develop the next TALIS survey, to be implemented in 2013. TALIS 2013 will provide insights into key factors that shape effective teaching practices and strong student learning outcomes. New insights that are expected from TALIS 2013 include:

- initial teacher training and mentoring as well as induction programmes;

- the format and content of teacher in-service professional development;

- expanded sources and methods of teacher appraisal and feedback and their perceived impact;

- distributed school leadership; and

- teacher professional and pedagogical practices, including student assessment policies and the use of ICT in the classroom. 



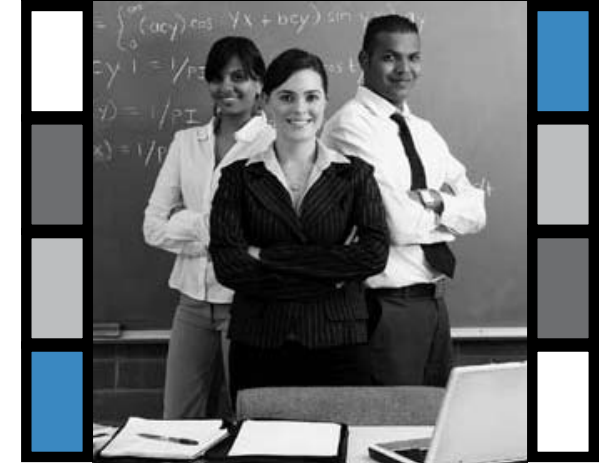

\section{Chapter 4}

\section{TEACHER ENGAGEMENT IN EDUCATIONAL REFORM}

Learning outcomes at school are the result of what happens in classrooms, thus only reforms that are successfully implemented in classrooms can be expected to be effective. One of the key conclusions of the Summit was that teacher engagement in the development and implementation of educational reform is crucial and school reform will not work unless it is supported from the bottom up. This requires those responsible for change to both communicate their aims well and involve the stakeholders who are affected. But it also requires teachers to contribute as the architects of change, not just its implementers. Some of the most successful reforms are those supported by strong unions rather than those that keep the union role weak. 
Significant improvement

is possible.

Tough-minded collaboration beats tough-minded confrontation.

Fundamental changes to the status quo can raise uncertainties that can trigger resistance.

Given the uncertainties that accompany change, stakeholders of ten value the status quo.

To address this, systems need to become better at communicating and building support for change.

\section{ACHIEVING EDUCATIONAL REFORM THAT WORKS}

While there continue to be major unresolved issues in the debate on effective teacher policies, both within and between countries, the Summit participants agreed that significant improvement is possible. Contrary to what is often assumed, a high-quality teaching force is not due simply to a traditional cultural respect for teachers but is a result of deliberate policy choices, carefully implemented over time. The highest performing countries show that thoughtfully designed and purposefully executed systemic efforts can build a highquality teacher workforce.

The previous chapters have discussed a range of features of school reform that can help make teachers more effective. These led to a key purpose of the Summit, which was examining how to achieve reforms that work for pupils through a constructive social dialogue between educational authorities and the organized teaching profession. The Summit revealed a strong consensus between governments and teacher organizations alike that major system improvement is essential and that there needs to be both pressure and support for people to get better. The Summit also revealed significant overlap between the professional conditions teachers are looking for and what is needed for school improvement but also areas where they may not be aligned. ${ }^{42}$ Societies have different political traditions to be managed and the tensions between different stakeholder groups and within stakeholder groups, including teacher organizations and governments, are real. But many systems have found ways to work constructively with teacher organizations by establishing structures and processes for consultation, both at the school and the national level. Inclusive, consultative policy processes are slower and do not prevent conflict but over time, such an approach seems to pay dividends.

Fundamental changes to the status quo can raise uncertainties that can trigger resistance from stakeholders, and without the active and willing engagement of teachers, most educational reforms fail. The chances for success in reform improve through effective consultation, a willingness to compromise and, above all, through the involvement of teachers in the planning and implementation of reform. In moving beyond consultation to involvement, the reform process becomes oriented towards transforming schools into learning organizations, with teaching professionals in the lead.

At the same time, stakeholder groups should not be able to exercise a veto over educational reforms that are mandated through democratic political processes. To do so would be to risk losing the public support on which education so critically depends. It is difficult to find the right balance, but open and ongoing systematic dialogue and consultation are fundamental to the process. Such dialogue should recognize that teachers are experts in teaching and learning and thus can make an essential contribution to the design of reforms. This chapter sets out some issues to be tackled, without pretending to offer a blueprint for how to engage teachers.

As in other areas of the public sector, reform can be harder if it is resisted by stakeholders who feel that they stand to lose from change. It is therefore not enough to design reforms capable of changing learning outcomes; to succeed, they need to address the legitimate concerns of stakeholders so that they are supported by those who deliver the system. This is a big challenge, in light of evidence that agents often prefer avoiding potential losses to acquiring potential gains, and to over-estimate the costs and/or under-estimate the benefits of change relative to the status quo.

In this sense, teachers are not exceptional in tending to protect the system they know in the face of uncertainty and failed reform in the past. However, this phenomenon is multiplied in educational reform because of the range of actors, including students, parents, teachers, employers and trade unions, who have stakes in educational outcomes. Uncertainty about costs is problematic because education infrastructure is large and implicates multiple levels of government, each of which is trying to minimize or shift the costs of reform. ${ }^{43}$ 
Moreover, provider interests tend to be well organized and generally command greater public trust than do politicians. It can be hard for the latter to make the case for reform on grounds of policy outcomes, because there is no consensus about how to assess outcomes in education. This is partly due to the complex mix of goals to be pursued (equity, efficiency, quality, choice, cost-containment, etc.), but it also reflects the lack of reliable, generally accepted indicators concerning the quality of educational outcomes and their value. Evidence-based reform is difficult where the evidence base is either lacking or contested. One consequence of this is that isolated facts or bits of data, or the emergence of a single high-profile study, can have a disproportionate impact on policy debates.

In overcoming these obstacles, education systems need to employ state-of-the-art knowledge, professional know-how and adequate institutional arrangements to disseminate information and lessons about the new tasks and responsibilities inherent in the reforms. Successful reforms have often involved significant investment in staff development, or clustering reforms to build up support for them in related institutions.

In September 2008, General Directors of Education Ministries in OECD countries met to discuss why some educational reforms succeed and others fail. They considered how to engage parents, teachers, and politicians to support reforms, and what changes the minds of stakeholders who initially resist reforms or their implementation. Several recurrent themes emerged from their exchange of experiences:

- Policy makers need to build consensus on the aims of educational reform and actively engage stakeholders, especially teachers, in formulating and implementing policy responses.

- Some reforms capitalize on external pressures or crises as part of building a compelling case for change.

- All political players and stakeholders need to develop more realistic expectations about the pace and nature of reforms to improve outcomes.

- Reforms need to be backed by sustainable financing.

- There is some shift away from reform initiatives per se towards building self-adjusting systems with rich feedback at all levels, incentives to react, and tools to strengthen capacities to deliver better outcomes.

- Investment is needed in change-management skills in the education system. Teachers need reassurance that they will be given the tools to change and recognition of their professional motivation to improve outcomes for their students.

- Evidence can be used more effectively to guide policy making, combining international benchmarks with national surveys and with inspectorates to achieve a better diagnosis.

- Evidence is most helpful when it is fed back to institutions along with information and tools about how they can use the information to improve outcomes.

- "Whole-of-government" approaches can include education in more comprehensive reforms. These need effective co-ordination and overall leadership across all the relevant ministries.

The OECD's recent review of reforms in public policy ${ }^{44}$ suggests that, in most circumstances, it pays to closely engage those who will be most directly affected by reform. Inclusive, consultative policy processes are no guarantee against conflict when sensitive reforms are under consideration, but over time, such an approach seems to pay dividends. In particular, it can create greater trust among the parties involved (Box 4.2). This may make all stakeholders more willing to rely on commitments to steps that will mitigate the cost of reform for them.
Experience of reform produces some useful pointers about how to engage teachers in educational reform. 
Teachers need to be active agents, not just in the implementation of reforms, but also in their design...

...and reform must be underpinned by solid research and analysis.
Recognition of the importance of engaging teachers is growing. Dialogue can involve conversations both within national professional bodies and among local groups of professionals.
Research literature devotes a great deal of attention to the question of when and how potential losers of reform might be compensated, whether by exempting them from the reform, at least for some period, or via some sort of alternative compensation. Failure to compensate may reinforce opposition to reform, while excessive compensation may be costly or may simply blunt the effects of the reform itself. It may also reinforce opposition to future reforms, as the perceived weakness of the government encourages agents to push for maximum concessions.

As noted before, teacher support for reform is also not merely an issue of politics and pragmatism. Research on the characteristics of effective professional development indicates that teachers must be active agents in analyzing their own practice in the light of professional standards, and their students' progress in the light of standards for student learning. Such engagement necessitates a clear and well-structured policy framework for reform. This depends greatly on the specific institutions and traditions of any given country. However, in every reform context, the roles and competencies of each actor need to be clearly defined. There should also be a strong commitment to sharing information, and to building trust and co-operation, as well as an explicit high-level commitment to the reform agenda from each partner.

Teacher engagement also requires consistent, co-ordinated efforts to persuade those affected of the need for reform and, in particular, to communicate the costs of non-reform. This may be particularly challenging when the opportunity costs of maintaining the status quo are less apparent than the costs of change.

Last but not least, policy design needs to be underpinned by solid research and analysis. If reform advocates can build a broad consensus among experts and the public in support of reform, and build that consensus by showing evidence of the need for reform, they are likely to be in a stronger position to implement the reforms successfully.

At a political level, the commitment to working in partnership with teachers to reform education is growing. When OECD Education Ministers met in Dublin in March 2004, there was a clear recognition of the importance of teacher engagement: "It is vital that teachers and their professional organizations are fully engaged in the debate about educational reform, and in the implementation of change." Ministers committed themselves to consultative and participatory processes, and were encouraged by the reports from some countries of the lead that teacher organizations were taking in designing new approaches to teacher appraisal and career structures. ${ }^{45}$ The importance of teacher engagement was also noted by the ILO/UNESCO Committee of Experts on the Application of the Recommendations concerning Teaching Personnel in 2003: "Social dialogue is the glue for successful educational reform. Without full involvement of teachers and their organizations - those most responsible for implementing reform - in key aspects of educational objectives and policies, education systems cannot hope to achieve quality education for all." 46 However, the Committee also observed that "social dialogue in education remains a fragile process of decision making in most [countries]." In 2006, the Committee noted: "The basic prerequisites for dialogue are a democratic culture, respect for rules and laws, and institutions or mechanisms that permit individuals to express their views individually or collectively through unions or associations on issues that affect their daily lives on both a personal and professional basis...this implies respect for professional freedom and the active participation of individual teachers in deciding a range of professional issues - curricula, pedagogy, student assessment and issues relating to the organization of education ... educational authorities and teacher unions should try to jointly analyze problems and find solutions. Participatory processes and consultations are not a panacea to resolve ... difficulties, but they are virtually the only mechanisms for overcoming suspicion and establishing a positive climate for making and implementing education policy." 47 
In addition to consultative mechanisms, there are also institutional arrangements that can help to promote dialogue and engage teachers and their professional associations in policy formation. Several countries have institutional arrangements providing teachers and other stakeholder groups with both a forum for policy development and, critically, a mechanism for profession-led standard-setting and quality-assurance in teacher education, teacher induction, teacher performance and career development (Boxes 4.1 to 4.6). Such organizations seek to obtain for teaching the combination of professional autonomy and public accountability that has long characterized other professions, such as medicine, engineering and law. This provides teachers with greater input into the criteria for entry to their profession, the standards for career advancement, and the basis on which ineffective teachers should leave the profession. Such an approach is also consistent with the ILO/ UNESCO Recommendation on the Status of Teachers, an instrument supported by UNESCO, ILO and OECD member states as well as teachers' unions.

\section{Box 4.1. Involving unions in reform in Australia}

Teacher unions are engaging in setting professional standards across the country.

National Professional Standards for Teachers were finalized by the Australian Institute for Teaching and School Leadership (AITSL) and endorsed by federal and state ministers in late December 2010. The Standards make explicit what teachers should know and be able to do across four career stages - graduate, proficient, highly accomplished and lead teacher - and across the three domains of professional knowledge, practice and engagement. AITSL includes the national education union in an independent structure that provides national leadership for the Commonwealth, state and territory governments in promoting excellence in the profession of teaching and school leadership. AITSL has responsibility for rigorous national professional standards, fostering and driving high-quality professional development for teachers and school leaders, working collaboratively across jurisdictions, and engaging with key professional bodies.

\section{Box 4.2. Building trust in Finland}

Finnish teachers have long enjoyed high professional status but only recently gained the level of trust that allows them to take responsibility for educational change.

Perhaps the greatest challenge to reform has to do with trust. Trust cannot be legislated. The strong role that trust plays in the relationship between government and teachers in Finland has suggested to some that lessons from Finland may be less relevant to other countries, especially if one views trust as a precondition for the kinds of deep institutional reforms embodied in the development of the comprehensive school. But in the case of the relationship between teachers and the larger society, the Finnish experience also shows that trust is at least as much a consequence of policy decisions as it is a pre-existing culture.

Finland has adopted a stance in which it is assumed that students will perform at their best when their teachers' morale is high, and teachers' morale will not be high if they perceive themselves to be under attack by the authorities. Trust in this case means eliciting teachers' views on what needs to be done to improve student performance, acting to the extent possible on those views, and working hard to help teachers develop the capacity required to meet their students' needs. Given the respect that teachers have historically enjoyed in Finland, there was a solid base on which to build reforms. But Finnish teachers only latterly gained their high level of autonomy over curriculum, assessment and other decisions. This granting of trust from the government, coupled with their newfound status as university graduates from highly selective programs, empowered teachers to practice their profession in ways that deepened the trust accorded them by parents and others in the community. 
In addition to system-level consultative mechanisms and policy-making bodies, it is also important that teacher engagement occurs at the school level. This can mean teachers taking responsibility for local change as members of "learning communities".

\section{Box 4.3. School-level teacher involvement in Sweden}

\section{The principle of consensus is a central feature of the Swedish decision-making process.}

Dialogue and collaboration among various parties in the education sector is common, although it does not always result in consensus on changes in education policy. At the central government level, representatives of the Swedish Association of Local Authorities and the teachers' unions often participate as experts in government committees or consultation groups on school policy. Stakeholders may also present their views through review bodies in connection with official inquiries and government proposals. Apart from such organized collaboration arrangements, various forms of talks and meetings offer opportunities for dialogue and consultations among parties.

At the local level and in individual schools, the Co-determination at Work Act guarantees that employers consult with employees before making major decisions about their workplace. Moreover, the employee representatives concluded an agreement in 1992 that sets the framework for collaboration in the workplace. Under this agreement, employers and teachers seek to reach solutions on matters concerning workplace conditions.

Conflict between unions and reform has best been avoided not where unions are weak but where they are strong and co-operate with reform.

\section{SECURING A STRATEGIC RELATIONSHIP BETWEEN GOVERNMENT AND TEACHERS" UNIONS}

Unions are sometimes perceived as interfering with promising school reform programs by giving higher priority to the unions' "bread and butter" issues than to what the evidence suggests students need to succeed. But the fact is that many of the countries with the strongest student performance also have strong teachers' unions, and the better a country's education system performs, the more likely that country is working constructively with its unions and treating its teachers as trusted professional partners. ${ }^{48}$

The discussion at the Summit revealed that there are different models of union-government relationships around the world. As the summary from the Summit notes, while $85 \%$ of teachers are members of the union in Norway, less than half of Polish teachers belong to the union. In Asia, some high-performing systems like Japan and Hong Kong have strong unions, while others, such as Singapore and China have teacher organizations that provide representation and professional development but do not engage in collective bargaining. In the Netherlands, there is a professional teachers association that is separate from the union. ${ }^{49}$

As illustrated in Box 4.4, issues of collective bargaining can be successfully separated from professional issues, where teachers and their organizations collaborate with ministry staff in self-governing bodies to oversee work on entry, discipline, and the professional development of teachers.

Last but not least, teachers' unions have developed their research capacities significantly in recent years. Their research units have also developed international links, principally through the Research Network of Education International. Within countries, there is evidence of growing links between union researchers and their counterparts in ministries and those in independent research institutes and universities. These developments are important because they can facilitate a constructive dialogue based on research and evidence. 


\section{Box 4.4. Successful collaboration in Ontario}

Ontario's educational reforms were accepted by teachers because the government consulted them on its implementation and ensured that it was implemented by professionals, not bureaucrats.

In 2003, the Canadian province of Ontario initiated a comprehensive reform to raise graduation rates as well as literacy and numeracy standards. This featured (1) strategies directly focused on improving the act of teaching; (2) careful and detailed attention to implementation, along with opportunities for teachers to practice new ideas and learn from their colleagues; (3) a single, integrated strategy and one set of expectations for both teachers and students; and (4) support for the reforms from teachers. Of all of these points, the last one, gaining teacher support, has been widely regarded as the most important element.

Central to this was the signing of a four-year collective bargaining agreement with the four major teachers' unions. In reaching the accord, the ministry for education was able to negotiate items that were consistent with both its educational strategy and the unions' interests, thus providing a basis for pushing forward the education agenda while creating a sustained period of labor peace that allowed for continued focus on educational improvement.

The ministry for education devoted significant efforts to winning over teachers, schools, and unions to its vision of reform. It had a clear theory of where responsibilities lay. The role of the ministry for education was to set clear expectations and targets, provide funding, create a working collective-bargaining agreement that would support improved teaching and learning, offer external expertise, and propose support for struggling schools. The role of the district was to align its personnel and hiring policies with the overall strategy, and to support the schools as they went through continuous processes of learning. The role of the school was considered crucial, as the place where change needed to occur; and while the mission and pressure came from the top, the role of non-school contributors to the reform was to support the learning and change occurring in the schools.

At a political level, those leading the reforms made a point of involving teachers and their representatives. The deputy minister met quarterly with their main unions, with superintendents' organizations, and with principal associations to review progress. The ministry for education also created the Ontario Education Partnership Table where a wider range of stakeholders could meet with ministry officials two to four times a year. This led to Working Tables, where smaller groups of stakeholders worked in more detail on particular issues. Important to these efforts was the signing of a four-year collective bargaining agreement with the four major teachers' unions in 2005, covering 2004 to 2008. In this agreement, the ministry for education was able to negotiate changes consistent with both the educational strategy and the unions' interests, including a reduction of class size and the creation of extra preparation time, which led to the creation of 5000 and 2000 new jobs, respectively. The agreement also provided money to hire a full or part-time staff member in each school who was responsible for student success. A second four-year agreement was signed in 2008.

To follow through on the reforms, the ministry for education developed a comprehensive implementation strategy. The ministry for education created a new 100-person secretariat responsible for building the capacity and expertise to implement the literacy and numeracy initiatives in elementary schools. This was separate from the ministry for education, and was thus able to start fresh without the usual bureaucratic obstacles. The reform also involved creating teams in each district and each school to lead the work on literacy and numeracy. In so doing, the ministry for education paired external expertise with sustained internal time and leadership to push the initiative. The transformation team of teachers, principals and subject-matter specialists had deep, on-the-ground experience that earned them the respect of teachers and schools, rather than being seen as representing a bureaucracy.

The strategy also sought to ensure that reform was really a two-way street and not something imposed from above.

The government pursued a similar strategy for the Student Success initiative in high schools. Rather than sending out a team from the ministry for education, they gave the districts money to hire a "Student Success leader" to co-ordinate efforts in their district. The ministry for education also gave money for the district leaders to meet and share strategies. Again, each high school was given support to hire a provincially-funded Student Success teacher and was required to create a Student Success team to identify students showing early signs of academic struggle and to design appropriate interventions. 


\section{Box 4.5. Transforming government-union relations in the United States}

\section{In Montgomery County, Maryland, a collaborative model for raising performance was agreed with unions.}

Montgomery County Public Schools (MCPS) is the sixteenth largest district in the United States. Long seen as a wealthy enclave, the county was becoming increasingly urbanized in 1999. Broad Acres Elementary School, located in a racially diverse neighborhood in the county's southeast corner, epitomized the challenges facing MCPS. Its students had performed so poorly on state assessments that the school qualified for restructuring. The school system faced the prospect of implementing a full-scale improvement process.

Neither school system leaders nor the Montgomery County Education Association (MCEA) believed school staff should be replaced. Instead, in 2000, collaboration between teachers and administration brought Broad Acres back from the brink and realized student-achievement levels commensurate with their peers in far wealthier areas of the county. And that is where Broad Acres has remained for the past eight years. Many schools throughout the county have replicated this process of targeted school improvement.

The collaborative culture has fostered both trust and engagement among all employee groups. An evolving outcome has been the development of three Professional Growth Systems (PGS) - for teachers, administrators, and support staff - each with a supportive Peer Assistance and Review component that allows for novice and underperforming staff to be mentored and returned to successful employment or removed from service if improvement is insufficient. The PGS integrates qualitative evaluation and professional growth. The teachers' PGS, for example, is based on six standards of performance derived from core propositions of the National Board for Professional Teaching Standards. It offers training for evaluators and teachers in order to establish a common language of successful teaching; establishes a professional growth cycle, in which a formal evaluation year is followed by sequential years dedicated to professional growth; provides for a jobembedded professional development program; and includes multiple factors in identifying teachers who will be involuntarily transferred.

In April 2010, MCEA and MCPS signed an agreement to affirm the use of student-performance data, including student and parent surveys, as required evidence for two of the six performance standards for evaluation. That initiative is representative of a shared focus on doing what's best for students.

\section{Box 4.6. Establishing career incentives in Norway}

\section{In Norway, governments and unions have co-operated to enhance and recognize teachers' competence.}

The Union of Education Norway (UEN) had long considered that there were too few career incentives for teachers. Existing career structures meant that teachers stopped teaching or taught less when they entered positions of educational leadership. In the 2008 negotiations with the central organization for local and regional governments, the UEN suggested introducing a new and higher wage scale for teachers to be promoted on the basis of competence. The suggestion was accepted, and procedures were agreed to promote highly competent teachers, as identified by the school leader. In 2008 the Norwegian Ministry of Education, the central organization for local and regional governments, the organization for teacher education institutions, and the UEN formed a partnership to introduce a system for in-service education for teachers. Around 2000 full-time study places in colleges and universities have been set aside for full or part-time studies. Teachers who participate are granted leave of absence with full pay for $80 \%$ of normal study time. Costs for substitute teachers are shared between the central government and the local employer. However, even though there is agreement between the central government and the other important stakeholders about these and other national initiatives to enhance teacher competence, the actual implementation must be decided by the local governments as employers, a total of 430 municipalities and 19 counties. Both for economic and political reasons, many employers have not implemented these initiatives in practice. 
Finally, in a process of educational reform that too often becomes politicized, it is essential to build a constructive political process in which teachers share the main goals of reform with politicians and administrators. This does not mean that the specific interests or concerns of particular groups can be ignored; there will always need to be compromise in making changes to well-established systems, particularly when some individuals are bound to be threatened by change. However, around the world, it has been shown that collaborative models of educational reform can be highly effective.

The success of different education systems varies significantly in equipping all students with important foundation skills. It was therefore appealing to bring together education leaders from high performing and rapidly improving education systems to explore to what extent educational success and related teacher policies transcends the specific characteristics of cultures and countries. The Summit participants agreed that there was enormous value in learning from international comparisons on this subject. As the report from the Summit notes, these comparisons help to get individuals outside of their own context and established patterns of thinking, provoke imagination, show where some of the successes and failures have been, and broaden both policymakers' and teacher organizations' views of possible options and trade-offs. They can help educators to think anew, to encourage innovation, and design new approaches that are informed by the world's best practices. This Summit is therefore a springboard for ongoing discussions of teacher policy in the 21 st century ${ }^{51}$ and the next Summit on the teaching profession will take place in 2012. 


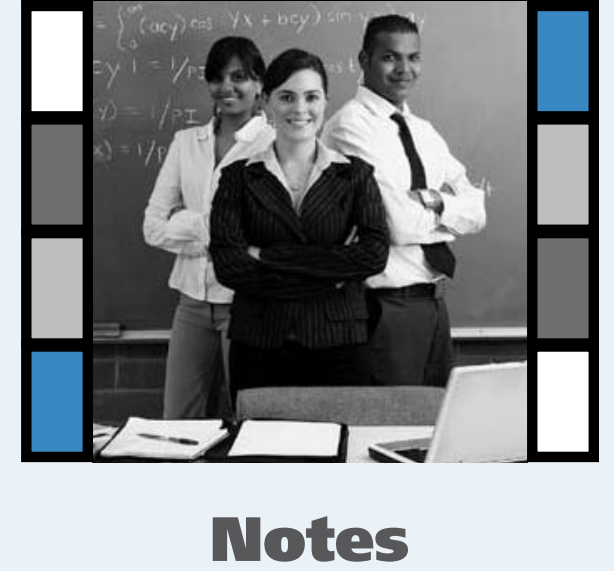

1. See OECD (2010), PISA 2009 Results - Volumes I-V, OECD Publishing, Paris.

2. See OECD (2009), Creating Effective Teaching and Learning Environments: First Results from TALIS, OECD Publishing, Paris.

3. See OECD (2005), Teachers Matter - Attracting, Developing and Retaining Effective Teachers, OECD Publishing, Paris.

4. See OECD (2010), Strong Performers and Successful Reformers - Lessons from PISA for the United States, OECD Publishing, Paris.

5. For details see http://www.oecd.org/document/24/0,3746,en_2649_39263231_44567960_1_1_1_1,00.html.

6. See OECD (2009), Evaluating and Rewarding the Quality of Teachers - International Practices, OECD Publishing, Paris.

7. See OECD (2010), Making Reform Happen, OECD Publishing, Paris.

8. Participants for the Summit were chosen on the basis of the performance of 15-year-old students in reading, mathematics and science on OECD's PISA 2009 assessment. To this end, the performance of these countries was averaged across the three subject areas. For data, see Annex A.

9. Asia Society (2011), Improving Teacher Quality around the World: The International Summit on the Teaching Profession, New York.

10. Asia Society (2011), Improving Teacher Quality around the World: The International Summit on the Teaching Profession, New York.

11. Asia Society (2011), Improving Teacher Quality around the World: The International Summit on the Teaching Profession, New York.

12. For an analysis of teacher demographics, see Indicator D8 in OECD (2003), Education at a Glance 2003: OECD Indicators, OECD Publishing, Paris. For updated data on the same topic, see the OECD online database at www.oecd.org/education/eag2011.

13. An important consideration here is the consistent finding in OECD countries that the responsiveness to incentives depends on the characteristics of individuals. For example, individuals in certain academic disciplines, such as science, and teachers with higher academic credentials are less likely to be attracted to teaching in the first place, and are less likely to return to teaching once they leave. Women often value the potential flexibility that teaching can offer, so improved leave provisions, opportunities for part-time employment and career breaks, and child care are likely to be particularly important to their career choices (for details, see OECD [2005], Teachers Matter - Attracting, Developing and Retaining Effective Teachers, OECD Publishing, Paris).

14. The admissions process occurs in two stages. The initial paper screen is based on the applicant's Matriculation Exam score, upper secondary school record, and out-of-school accomplishments. Those who pass that screening must then take a written exam, be observed in a teaching-like activity in which their interaction and communication skills can be assessed, and be interviewed to assess, among other things, the strength of their motivation to teach (for details see OECD [2010], Strong Performers and Successful Reformers - Lessons from PISA for the United States, OECD Publishing, Paris).

15. For data, see OECD (2010), PISA 2009 Results: What Makes a School Successful? Resources, Policies and Practices, OECD Publishing, Paris.

16. It should be noted that autonomy of schools in managing their resources is positively related to school performance in PISA 2009 only in conjunction with established accountability arrangements. In the absence of accountability arrangements, school autonomy is related negatively to school performance (for data, see OECD [2010], PISA 2009 Results: What Makes a School Successful? Resources, Policies and Practices, OECD Publishing, Paris).

17. For data, see OECD (2010), PISA 2009 Results: What Makes a School Successful? Resources, Policies and Practices, OECD Publishing, Paris. 
18. In upper secondary general education, in 2009, the lowest ratios are found in the Czech Republic (0.53) and the partner countries Israel (0.56) and Slovenia (0.55). Relative teachers' salaries in primary and lower secondary education are highest in Australia (0.93 in primary, 0.94 in lower secondary), Belgium (Flemish Community) (0.90), Germany (0.89 in primary, 0.97 in lower secondary), New Zealand (0.97), Scotland (0.89), Spain (1.12 in primary, 1.26 in lower secondary) and Sweden (0.90 in primary, 0.93 in lower secondary). In upper secondary education, the ratios are highest in Belgium (Flemish Community) (1.14), Belgium (French Community) (1.10), Denmark (1.06), Finland (1.02), Germany (1.04), the Netherlands (1.07) and Spain (1.28) (for data, see the OECD's 2010 edition of Education at a Glance, Table D3.1).

19. See OECD (2005), Teachers Matter - Attracting, Developing and Retaining Effective Teachers, OECD Publishing, Paris.

20. Asia Society (2011), Improving Teacher Quality around the World: The International Summit on the Teaching Profession, New York.

21. See OECD (2010), Strong Performers and Successful Reformers - Lessons from PISA for the United States, OECD Publishing, Paris.

22. Asia Society (2011), Improving Teacher Quality around the World: The International Summit on the Teaching Profession, New York.

23. See page 4 of the Joint ILO/UNESCO Committee of Experts on the Application of the Recommendations concerning Teaching Personnel (CEART), Paris, October 2009.

24. See OECD (2005), Teachers Matter - Attracting, Developing and Retaining Effective Teachers, OECD Publishing, Paris.

25. TALIS asked teachers about their professional development activities during the 18 months prior to the survey. This period of time was chosen in order to cover activities over almost two school years in order to give a more representative picture and lessen possible distortions due to unusually busy or lean periods of development, and to ensure a manageable period for teachers' recall. Teachers were first asked to indicate whether or not they had participated in each of the following activities: (1) courses/workshops (e.g. on subject matter or methods and/or other education-related topics); (2) education conferences or seminars (at which teachers and/or researchers present their research results and discuss education problems); (3) qualification program (e.g. a degree program); (4) observation visits to other schools; (5) participation in a network of teachers formed specifically for the professional development of teachers; (6) individual or collaborative research on a topic of professional interest; and (7) mentoring and/or peer observation and coaching, as part of a formal school arrangement. Teachers were able to indicate participation in multiple activities. TALIS then asked teachers how many days of professional development they had attended in the 18 months prior to the survey and how many of these days were compulsory (for details, see OECD [2009], Creating Effective Teaching and Learning Environments: First Results from TALIS, OECD Publishing, Paris).

26. The intensity of teacher participation in professional development varies considerably across countries, with Korea and Mexico seeing teachers participating on average for over 30 days in 18 months, twice the average rate. Within-country variation in the intensity of professional development can also be high, most notably in Italy, Mexico, Korea, Poland and Spain (for data see OECD [2009], Creating Effective Teaching and Learning Environments: First Results from TALIS, OECD Publishing, Paris).

27. Jaquith, Ann, Mindich, Dan, Wei, Ruth Chung, and Darling-Hammond, Linda (2010), Teacher Professional Learning in the United States: Case Studies of State Policies and Strategies, Technical Report, Stanford Center for Opportunity Policy in Education and Learning Forward, December 2010.

28. For data, see OECD (2009), Creating Effective Teaching and Learning Environments: First Results from TALIS, OECD Publishing, Paris.

29. For data, see Figure IV.3.3a in OECD (2010), PISA 2009 Results: What Makes a School Successful? Resources, Policies and Practices, OECD Publishing, Paris.

30. For data, see Indicator D3 in OECD (2007), Education at a Glance 2007: OECD Indicators, OECD Publishing, Paris.

31. See, for example, the Commonwealth Teachers Recruitment Protocol of 2004, developed at the request of the 15th Conference of Commonwealth Education Ministers, Edinburgh, UK 2003.

32. For an analysis, see OECD (2005), Teachers Matter - Attracting, Developing and Retaining Effective Teachers, OECD Publishing, Paris.

33. For data, see OECD (2009), Creating Effective Teaching and Learning Environments: First Results from TALIS, OECD Publishing, Paris.

34. Asia Society (2011), Improving Teacher Quality around the World: The International Summit on the Teaching Profession, New York.

35. Asia Society (2011), Improving Teacher Quality around the World: The International Summit on the Teaching Profession, New York. 
36. For data, see OECD (2009), Creating Effective Teaching and Learning Environments: First Results from TALIS, OECD Publishing, Paris.

37. For data on starting, average and ending salaries, see OECD (2010), Education at a Glance 2010: OECD Indicators, OECD Publishing, Paris.

38. For data, see OECD (2010), Education at a Glance 2010: OECD Indicators, OECD Publishing, Paris.

39. The OECD does not collect data on payment amounts but on whether the additional payments are available and on the level at which the decision to award such payments is taken (for data, see Table D3.3a and Tables D3.3b, D3.3c and D3.3d available on line, as well as Annex 3 at www.oecd.org/edu/eag2010).

40. For an analysis, see OECD (2009), Evaluating and Rewarding the Quality of Teachers - International Practices, OECD Publishing, Paris.

41. Data Quality Campaign, 2009, http://www.dataqualitycampaign.org/survey/elements.

42. Asia Society (2011), Improving Teacher Quality around the World: The International Summit on the Teaching Profession, New York.

43. It should be noted that it is difficult to isolate the costs and benefits of particular measures because of the large number of simultaneous influences on outcomes. Thus, it is rarely possible to predict clear, identifiable links between policies and outcomes, especially given the time lags involved. It can take years to design and adopt a reform, and it may be a decade or more before its impact is really felt. This weakens not only incentives for elected politicians with limited time horizons to adopt reforms, but also the engagement of teachers who need to deliver them. In many countries, these issues are complicated by the difficulty of coordinating reform across different levels of government and across multiple regional and local jurisdictions. Education systems extend from local schools and independent universities to national ministries. The responsibilities of institutions and different levels of government vary from country to country, as do the relative importance and independence of non-public providers. Reforms need to take into account the respective responsibilities of different actors.

44. See OECD (2010), Making Reform Happen, OECD Publishing, Paris

45. See Dempsey, N. (2004), Chair's Summary, Meeting of OECD Education Ministers: Raising the Quality of Learning for All, Dublin, Ireland, www.oecd.org/edumin2004.

46. See ILO/UNESCO (2003), Committee of Experts on the Application of the Recommendations concerning Teaching Personnel, ILO/UNESCO (CEART), Geneva and Paris.

47. See ILO/UNESCO CEART (2006).

48. One review of the research on teacher organizations as policy actors has been published recently by Nina Bascia. See also John Bangs, John MacBeath and Maurice Galton, Reinventing Schools, Reforming Teaching, Cambridge, 2010.

49. Asia Society (2011), Improving Teacher Quality around the World: The International Summit on the Teaching Profession, New York.

50. Asia Society (2011), Improving Teacher Quality around the World: The International Summit on the Teaching Profession, New York.

51. Asia Society (2011), Improving Teacher Quality around the World: The International Summit on the Teaching Profession, New York. 



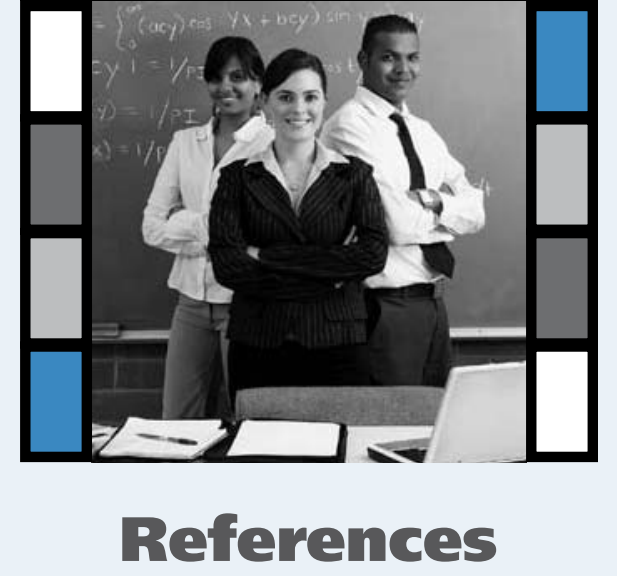

Bangs John, John MacBeath and Maurice Galton (2010), Reinventing Schools, Reforming Teaching: From Political Visions to Classroom Reality, Routledge, Cambridge.

Dempsey, N. (2004), Raising the Quality of Learning for All, Chair's Summary, Meeting of OECD Education Ministers, Dublin, www.oecd.org/edumin 2004.

OECD (2003), Education at a Glance 2003: OECD Indicators, OECD Publishing, Paris.

OECD (2005), Teachers Matter - Attracting, Developing and Retaining Effective Teachers, OECD Publishing, Paris.

OECD (2007), Education at a Glance 2007: OECD Indicators, OECD Publishing, Paris.

OECD (2009), Creating Effective Teaching and Learning Environments: First Results from TALIS, OECD Publishing, Paris.

OECD (2009), Evaluating and Rewarding the Quality of Teachers - International Practices, OECD Publishing, Paris.

OECD (2010), Education at a Glance 2010: OECD Indicators, OECD Publishing, Paris.

OECD (2010), Strong Performers and Successful Reformers - Lessons from PISA for the United States, OECD Publishing, Paris.

OECD (2010), PISA 2009 Results - Volumes I-V, OECD Publishing, Paris.

OECD (2010), Making Reform Happen, OECD Publishing, Paris. 



\section{Figure A.1}

\section{Comparing countries' performance in reading}

\begin{tabular}{|c|c|c|}
\hline & & $\begin{array}{l}\text { Statistically significantly above the OECD average } \\
\text { Not statistically significantly different from the OECD average } \\
\text { Statistically significantly below the OECD average }\end{array}$ \\
\hline Mean & Comparison country & Countries whose mean score is NOT statistically significantly different from that of the comparison country \\
\hline 556 & Shanghai-China & \\
\hline 539 & Korea & Finland, Hong Kong-China \\
\hline 536 & Finland & Korea, Hong Kong-China \\
\hline 533 & Hong Kong-China & Korea, Finland \\
\hline 526 & Singapore & Canada, New Zealand, Japan \\
\hline 524 & Canada & Singapore, New Zealand, Japan \\
\hline 521 & New Zealand & Singapore, Canada, Japan, Australia \\
\hline 520 & Japan & Singapore, Canada, New Zealand, Australia, Netherlands \\
\hline 515 & Australia & New Zealand, Japan, Netherlands \\
\hline 508 & Netherlands & Japan, Australia, Belgium, Norway, Estonia, Switzerland, Poland, Iceland, United States, Liechtenstein, Sweden, Germany \\
\hline 506 & Belgium & Netherlands, Norway, Estonia, Switzerland, Poland, United States, Liechtenstein \\
\hline 503 & Norway & Netherlands, Belgium, Estonia, Switzerland, Poland, Iceland, United States, Liechtenstein, Sweden, Germany, Ireland, France \\
\hline 501 & Estonia & $\begin{array}{l}\text { Netherlands, Belgium, Norway, Switzerland, Poland, Iceland, United States, Liechtenstein, Sweden, Germany, Ireland, France, Chinese Taipei, } \\
\text { Denmark, United Kingdom, Hungary }\end{array}$ \\
\hline 501 & Switzerland & $\begin{array}{l}\text { Netherlands, Belgium, Norway, Estonia, Poland, Iceland, United States, Liechtenstein, Sweden, Germany, Ireland, France, Chinese Taipei, } \\
\text { Denmark, United Kingdom, Hungary }\end{array}$ \\
\hline 500 & Poland & $\begin{array}{l}\text { Netherlands, Belgium, Norway, Estonia, Switzerland, Iceland, United States, Liechtenstein, Sweden, Germany, Ireland, France, Chinese Taipei, } \\
\text { Denmark, United Kingdom, Hungary }\end{array}$ \\
\hline 500 & Iceland & Netherlands, Norway, Estonia, Switzerland, Poland, United States, Liechtenstein, Sweden, Germany, Ireland, France, Chinese Taipei, Hungary \\
\hline 500 & United States & $\begin{array}{l}\text { Netherlands, Belgium, Norway, Estonia, Switzerland, Poland, Iceland, Liechtenstein, Sweden, Germany, Ireland, France, Chinese Taipei, } \\
\text { Denmark, United Kingdom, Hungary }\end{array}$ \\
\hline 499 & Liechtenstein & $\begin{array}{l}\text { Netherlands, Belgium, Norway, Estonia, Switzerland, Poland, Iceland, United States, Sweden, Germany, Ireland, France, Chinese Taipei, } \\
\text { Denmark, United Kingdom, Hungary }\end{array}$ \\
\hline 497 & Sweden & $\begin{array}{l}\text { Netherlands, Norway, Estonia, Switzerland, Poland, Iceland, United States, Liechtenstein, Germany, Ireland, France, Chinese Taipei, Denmark, } \\
\text { United Kingdom, Hungary, Portugal }\end{array}$ \\
\hline 497 & Germany & $\begin{array}{l}\text { Netherlands, Norway, Estonia, Switzerland, Poland, Iceland, United States, Liechtenstein, Sweden, Ireland, France, Chinese Taipei, Denmark, } \\
\text { United Kingdom, Hungary }\end{array}$ \\
\hline 496 & Ireland & $\begin{array}{l}\text { Norway, Estonia, Switzerland, Poland, Iceland, United States, Liechtenstein, Sweden, Germany, France, Chinese Taipei, Denmark, United } \\
\text { Kingdom, Hungary, Portugal }\end{array}$ \\
\hline 496 & France & $\begin{array}{l}\text { Norway, Estonia, Switzerland, Poland, Iceland, United States, Liechtenstein, Sweden, Germany, Ireland, Chinese Taipei, Denmark, United } \\
\text { Kingdom, Hungary, Portugal }\end{array}$ \\
\hline 495 & Chinese Taipei & $\begin{array}{l}\text { Estonia, Switzerland, Poland, Iceland, United States, Liechtenstein, Sweden, Germany, Ireland, France, Denmark, United Kingdom, Hungary, } \\
\text { Portugal }\end{array}$ \\
\hline 495 & Denmark & Estonia, Switzerland, Poland, United States, Liechtenstein, Sweden, Germany, Ireland, France, Chinese Taipei, United Kingdom, Hungary, Portugal \\
\hline 494 & United Kingdom & Estonia, Switzerland, Poland, United States, Liechtenstein, Sweden, Germany, Ireland, France, Chinese Taipei, Denmark, Hungary, Portugal \\
\hline 494 & Hungary & $\begin{array}{l}\text { Estonia, Switzerland, Poland, Iceland, United States, Liechtenstein, Sweden, Germany, Ireland, France, Chinese Taipei, Denmark, United } \\
\text { Kingdom, Portugal }\end{array}$ \\
\hline 489 & Portugal & Sweden, Ireland, France, Chinese Taipei, Denmark, United Kingdom, Hungary, Macao-China, Italy, Latvia, Slovenia, Greece \\
\hline 487 & Macao-China & Portugal, Italy, Latvia, Greece \\
\hline 486 & Italy & Portugal, Macao-China, Latvia, Slovenia, Greece, Spain \\
\hline 484 & Latvia & Portugal, Macao-China, Italy, Slovenia, Greece, Spain, Czech Republic, Slovak Republic \\
\hline 483 & Slovenia & Portugal, Italy, Latvia, Greece, Spain, Czech Republic \\
\hline 483 & Greece & Portugal, Macao-China, Italy, Latvia, Slovenia, Spain, Czech Republic, Slovak Republic, Croatia, Israel \\
\hline 481 & Spain & Italy, Latvia, Slovenia, Greece, Czech Republic, Slovak Republic, Croatia, Israel \\
\hline 478 & Czech Republic & Latvia, Slovenia, Greece, Spain, Slovak Republic, Croatia, Israel, Luxembourg, Austria \\
\hline 477 & Slovak Republic & Latvia, Greece, Spain, Czech Republic, Croatia, Israel, Luxembourg, Austria \\
\hline 476 & Croatia & Greece, Spain, Czech Republic, Slovak Republic, Israel, Luxembourg, Austria, Lithuania \\
\hline 474 & Israel & Greece, Spain, Czech Republic, Slovak Republic, Croatia, Luxembourg, Austria, Lithuania, Turkey \\
\hline 472 & Luxembourg & Czech Republic, Slovak Republic, Croatia, Israel, Austria, Lithuania \\
\hline 470 & Austria & Czech Republic, Slovak Republic, Croatia, Israel, Luxembourg, Lithuania, Turkey \\
\hline 468 & Lithuania & Croatia, Israel, Luxembourg, Austria, Turkey \\
\hline 464 & Turkey & Israel, Austria, Lithuania, Dubai (UAE), Russian Federation \\
\hline 459 & Dubai (UAE) & Turkey, Russian Federation \\
\hline 459 & Russian Federation & Turkey, Dubai (UAE) \\
\hline 449 & Chile & Serbia \\
\hline 442 & Serbia & Chile, Bulgaria \\
\hline 429 & Bulgaria & Serbia, Uruguay, Mexico, Romania, Thailand, Trinidad and Tobago \\
\hline 426 & Uruguay & Bulgaria, Mexico, Romania, Thailand \\
\hline 425 & Mexico & Bulgaria, Uruguay, Romania, Thailand \\
\hline 424 & Romania & Bulgaria, Uruguay, Mexico, Thailand, Trinidad and Tobago \\
\hline 421 & Thailand & Bulgaria, Uruguay, Mexico, Romania, Trinidad and Tobago, Colombia \\
\hline 416 & Trinidad and Tobago & Bulgaria, Romania, Thailand, Colombia, Brazil \\
\hline 413 & Colombia & Thailand, Trinidad and Tobago, Brazil, Montenegro, Jordan \\
\hline 412 & Brazil & Trinidad and Tobago, Colombia, Montenegro, Jordan \\
\hline 408 & Montenegro & Colombia, Brazil, Jordan, Tunisia, Indonesia, Argentina \\
\hline 405 & Jordan & Colombia, Brazil, Montenegro, Tunisia, Indonesia, Argentina \\
\hline 404 & Tunisia & Montenegro, Jordan, Indonesia, Argentina \\
\hline 402 & Indonesia & Montenegro, Jordan, Tunisia, Argentina \\
\hline 398 & Argentina & Montenegro, Jordan, Tunisia, Indonesia, Kazakhstan \\
\hline 390 & Kazakhstan & Argentina, Albania \\
\hline 385 & Albania & Kazakhstan, Panama \\
\hline 372 & Qatar & Panama, Peru \\
\hline 371 & Panama & Albania, Qatar, Peru, Azerbaijan \\
\hline 370 & Peru & Qatar, Panama, Azerbaijan \\
\hline 362 & Azerbaijan & Panama, Peru \\
\hline 314 & Kyrgyzstan & \\
\hline
\end{tabular}

Source: OECD, PISA 2009 Database.

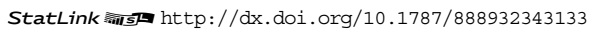




\section{Figure A.2}

\section{Comparing countries' performance in mathematics}

\begin{tabular}{|c|c|c|}
\hline \multirow[b]{2}{*}{ Mean } & \multirow[b]{2}{*}{ Comparison country } & $\begin{array}{l}\text { Statistically significantly above the OECD average } \\
\text { Not statistically significantly different from the OECD average } \\
\text { Statistically significantly below the OECD average }\end{array}$ \\
\hline & & Countries whose mean score is NOT statistically significantly different from that of the comparison country \\
\hline 600 & Shanghai-China & \\
\hline 562 & Singapore & \\
\hline 555 & Hong Kong-China & Korea \\
\hline 546 & Korea & Hong Kong-China, Chinese Taipei, Finland, Liechtenstein \\
\hline 543 & Chinese Taipei & Korea, Finland, Liechtenstein, Switzerland \\
\hline 541 & Finland & Korea, Chinese Taipei, Liechtenstein, Switzerland \\
\hline 536 & Liechtenstein & Korea, Chinese Taipei, Finland, Switzerland, Japan, Netherlands \\
\hline 534 & Switzerland & Chinese Taipei, Finland, Liechtenstein, Japan, Canada, Netherlands \\
\hline 529 & Japan & Liechtenstein, Switzerland, Canada, Netherlands, Macao-China \\
\hline 527 & Canada & Switzerland, Japan, Netherlands, Macao-China \\
\hline 526 & Netherlands & Liechtenstein, Switzerland, Japan, Canada, Macao-China, New Zealand \\
\hline 525 & Macao-China & Japan, Canada, Netherlands \\
\hline 519 & New Zealand & Netherlands, Belgium, Australia, Germany \\
\hline 515 & Belgium & New Zealand, Australia, Germany, Estonia \\
\hline 514 & Australia & New Zealand, Belgium, Germany, Estonia \\
\hline 513 & Germany & New Zealand, Belgium, Australia, Estonia, Iceland \\
\hline 512 & Estonia & Belgium, Australia, Germany, Iceland \\
\hline 507 & Iceland & Germany, Estonia, Denmark \\
\hline 503 & Denmark & Iceland, Slovenia, Norway, France, Slovak Republic \\
\hline 501 & Slovenia & Denmark, Norway, France, Slovak Republic, Austria \\
\hline 498 & Norway & Denmark, Slovenia, France, Slovak Republic, Austria, Poland, Sweden, Czech Republic, United Kingdom, Hungary \\
\hline 497 & France & Denmark, Slovenia, Norway, Slovak Republic, Austria, Poland, Sweden, Czech Republic, United Kingdom, Hungary \\
\hline 497 & Slovak Republic & Denmark, Slovenia, Norway, France, Austria, Poland, Sweden, Czech Republic, United Kingdom, Hungary \\
\hline 496 & Austria & Slovenia, Norway, France, Slovak Republic, Poland, Sweden, Czech Republic, United Kingdom, Hungary, United States \\
\hline 495 & Poland & Norway, France, Slovak Republic, Austria, Sweden, Czech Republic, United Kingdom, Hungary, Luxembourg, United States, Portugal \\
\hline 494 & Sweden & Norway, France, Slovak Republic, Austria, Poland, Czech Republic, United Kingdom, Hungary, Luxembourg, United States, Ireland, Portugal \\
\hline 493 & Czech Republic & Norway, France, Slovak Republic, Austria, Poland, Sweden, United Kingdom, Hungary, Luxembourg, United States, Ireland, Portugal \\
\hline 492 & United Kingdom & Norway, France, Slovak Republic, Austria, Poland, Sweden, Czech Republic, Hungary, Luxembourg, United States, Ireland, Portugal \\
\hline 490 & Hungary & $\begin{array}{l}\text { Norway, France, Slovak Republic, Austria, Poland, Sweden, Czech Republic, United Kingdom, Luxembourg, United States, Ireland, Portugal, } \\
\text { Spain, Italy, Latvia }\end{array}$ \\
\hline 489 & Luxembourg & Poland, Sweden, Czech Republic, United Kingdom, Hungary, United States, Ireland, Portugal \\
\hline 487 & United States & Austria, Poland, Sweden, Czech Republic, United Kingdom, Hungary, Luxembourg, Ireland, Portugal, Spain, Italy, Latvia \\
\hline 487 & Ireland & Sweden, Czech Republic, United Kingdom, Hungary, Luxembourg, United States, Portugal, Spain, Italy, Latvia \\
\hline 487 & Portugal & Poland, Sweden, Czech Republic, United Kingdom, Hungary, Luxembourg, United States, Ireland, Spain, Italy, Latvia \\
\hline 483 & Spain & Hungary, United States, Ireland, Portugal, Italy, Latvia \\
\hline 483 & Italy & Hungary, United States, Ireland, Portugal, Spain, Latvia \\
\hline 482 & Latvia & Hungary, United States, Ireland, Portugal, Spain, Italy, Lithuania \\
\hline 477 & Lithuania & Latvia \\
\hline 468 & Russian Federation & Greece, Croatia \\
\hline 466 & Greece & Russian Federation, Croatia \\
\hline 460 & Croatia & Russian Federation, Greece \\
\hline 453 & Dubai (UAE) & Israel, Turkey \\
\hline 447 & Israel & Dubai (UAE), Turkey, Serbia \\
\hline 445 & Turkey & Dubai (UAE), Israel, Serbia \\
\hline 442 & Serbia & Israel, Turkey \\
\hline 431 & Azerbaijan & Bulgaria, Romania, Uruguay \\
\hline 428 & Bulgaria & Azerbaijan, Romania, Uruguay, Chile, Thailand, Mexico \\
\hline 427 & Romania & Azerbaijan, Bulgaria, Uruguay, Chile, Thailand \\
\hline 427 & Uruguay & Azerbaijan, Bulgaria, Romania, Chile \\
\hline 421 & Chile & Bulgaria, Romania, Uruguay, Thailand, Mexico \\
\hline 419 & Thailand & Bulgaria, Romania, Chile, Mexico, Trinidad and Tobago \\
\hline 419 & Mexico & Bulgaria, Chile, Thailand \\
\hline 414 & Trinidad and Tobago & Thailand \\
\hline 405 & Kazakhstan & Montenegro \\
\hline 403 & Montenegro & Kazakhstan \\
\hline 388 & Argentina & Jordan, Brazil, Colombia, Albania \\
\hline 387 & Jordan & Argentina, Brazil, Colombia, Albania \\
\hline 386 & Brazil & Argentina, Jordan, Colombia, Albania \\
\hline 381 & Colombia & Argentina, Jordan, Brazil, Albania, Indonesia \\
\hline 377 & Albania & Argentina, Jordan, Brazil, Colombia, Tunisia, Indonesia \\
\hline 371 & \begin{tabular}{|l|} 
Tunisia \\
\end{tabular} & Albania, Indonesia, Qatar, Peru, Panama \\
\hline 371 & Indonesia & Colombia, Albania, Tunisia, Qatar, Peru, Panama \\
\hline 368 & Qatar & Tunisia, Indonesia, Peru, Panama \\
\hline 365 & \begin{tabular}{|l|} 
Peru \\
\end{tabular} & Tunisia, Indonesia, Qatar, Panama \\
\hline 360 & Panama & Tunisia, Indonesia, Qatar, Peru \\
\hline 331 & Kyrgyzstan & \\
\hline
\end{tabular}

Source: OECD, PISA 2009 Database.

StatLink ants $\mathrm{http}: / / \mathrm{dx}$.doi.org/10.1787/888932343152 


\section{Figure A.3}

\section{Comparing countries' performance in science}

\begin{tabular}{|c|c|c|}
\hline \multirow[b]{2}{*}{ Mean } & \multirow[b]{2}{*}{ Comparison country } & $\begin{array}{l}\text { Statistically significantly above the OECD average } \\
\text { Not statistically significantly different from the OECD average } \\
\text { Statistically significantly below the OECD average }\end{array}$ \\
\hline & & Countries whose mean score is NOT statistically significantly different from that comparison country \\
\hline 575 & Shanghai-China & \\
\hline 554 & Finland & Hong Kong-China \\
\hline 549 & Hong Kong-China & Finland \\
\hline 542 & Singapore & Japan, Korea \\
\hline 539 & Japan & Singapore, Korea, New Zealand \\
\hline 538 & Korea & Singapore, Japan, New Zealand \\
\hline 532 & New Zealand & Japan, Korea, Canada, Estonia, Australia, Netherlands \\
\hline 529 & Canada & New Zealand, Estonia, Australia, Netherlands \\
\hline 528 & Estonia & New Zealand, Canada, Australia, Netherlands, Germany, Liechtenstein \\
\hline 527 & Australia & New Zealand, Canada, Estonia, Netherlands, Chinese Taipei, Germany, Liechtenstein \\
\hline 522 & Netherlands & New Zealand, Canada, Estonia, Australia, Chinese Taipei, Germany, Liechtenstein, Switzerland, United Kingdom, Slovenia \\
\hline 520 & Chinese Taipei & Australia, Netherlands, Germany, Liechtenstein, Switzerland, United Kingdom \\
\hline 520 & Germany & Estonia, Australia, Netherlands, Chinese Taipei, Liechtenstein, Switzerland, United Kingdom \\
\hline 520 & Liechtenstein & Estonia, Australia, Netherlands, Chinese Taipei, Germany, Switzerland, United Kingdom \\
\hline 517 & Switzerland & Netherlands, Chinese Taipei, Germany, Liechtenstein, United Kingdom, Slovenia, Macao-China \\
\hline 514 & United Kingdom & Netherlands, Chinese Taipei, Germany, Liechtenstein, Switzerland, Slovenia, Macao-China, Poland, Ireland \\
\hline 512 & Slovenia & Netherlands, Switzerland, United Kingdom, Macao-China, Poland, Ireland, Belgium \\
\hline 511 & Macao-China & Switzerland, United Kingdom, Slovenia, Poland, Ireland, Belgium \\
\hline 508 & Poland & United Kingdom, Slovenia, Macao-China, Ireland, Belgium, Hungary, United States \\
\hline 508 & Ireland & United Kingdom, Slovenia, Macao-China, Poland, Belgium, Hungary, United States, Czech Republic, Norway \\
\hline 507 & Belgium & Slovenia, Macao-China, Poland, Ireland, Hungary, United States, Czech Republic, Norway, France \\
\hline 503 & Hungary & Poland, Ireland, Belgium, United States, Czech Republic, Norway, Denmark, France, Sweden, Austria \\
\hline 502 & United States & Poland, Ireland, Belgium, Hungary, Czech Republic, Norway, Denmark, France, Iceland, Sweden, Austria, Latvia, Portugal \\
\hline 500 & Czech Republic & Ireland, Belgium, Hungary, United States, Norway, Denmark, France, Iceland, Sweden, Austria, Latvia, Portugal \\
\hline 500 & Norway & Ireland, Belgium, Hungary, United States, Czech Republic, Denmark, France, Iceland, Sweden, Austria, Latvia, Portugal \\
\hline 499 & Denmark & Hungary, United States, Czech Republic, Norway, France, Iceland, Sweden, Austria, Latvia, Portugal \\
\hline 498 & France & Belgium, Hungary, United States, Czech Republic, Norway, Denmark, Iceland, Sweden, Austria, Latvia, Portugal, Lithuania, Slovak Republic \\
\hline 496 & Iceland & United States, Czech Republic, Norway, Denmark, France, Sweden, Austria, Latvia, Portugal, Lithuania, Slovak Republic \\
\hline 495 & Sweden & Hungary, United States, Czech Republic, Norway, Denmark, France, Iceland, Austria, Latvia, Portugal, Lithuania, Slovak Republic, Italy \\
\hline 494 & Austria & $\begin{array}{l}\text { Hungary, United States, Czech Republic, Norway, Denmark, France, Iceland, Sweden, Latvia, Portugal, Lithuania, Slovak Republic, Italy, Spain, } \\
\text { Croatia }\end{array}$ \\
\hline 494 & Latvia & United States, Czech Republic, Norway, Denmark, France, Iceland, Sweden, Austria, Portugal, Lithuania, Slovak Republic, Italy, Spain, Croatia \\
\hline 493 & Portugal & United States, Czech Republic, Norway, Denmark, France, Iceland, Sweden, Austria, Latvia, Lithuania, Slovak Republic, Italy, Spain, Croatia \\
\hline 491 & Lithuania & France, Iceland, Sweden, Austria, Latvia, Portugal, Slovak Republic, Italy, Spain, Croatia \\
\hline 490 & Slovak Republic & France, Iceland, Sweden, Austria, Latvia, Portugal, Lithuania, Italy, Spain, Croatia \\
\hline 489 & Italy & Sweden, Austria, Latvia, Portugal, Lithuania, Slovak Republic, Spain, Croatia \\
\hline 488 & Spain & Austria, Latvia, Portugal, Lithuania, Slovak Republic, Italy, Croatia, Luxembourg \\
\hline 486 & Croatia & Austria, Latvia, Portugal, Lithuania, Slovak Republic, Italy, Spain, Luxembourg, Russian Federation \\
\hline 484 & Luxembourg & Spain, Croatia, Russian Federation \\
\hline 478 & Russian Federation & Croatia, Luxembourg, Greece \\
\hline 470 & Greece & Russian Federation, Dubai (UAE) \\
\hline 466 & Dubai (UAE) & Greece \\
\hline 455 & Israel & Turkey, Chile \\
\hline 454 & Turkey & Israel, Chile \\
\hline 447 & Chile & Israel, Turkey, Serbia, Bulgaria \\
\hline 443 & Serbia & Chile, Bulgaria \\
\hline 439 & Bulgaria & Chile, Serbia, Romania, Uruguay \\
\hline 428 & Romania & Bulgaria, Uruguay, Thailand \\
\hline 427 & Uruguay & Bulgaria, Romania, Thailand \\
\hline 425 & Thailand & Romania, Uruguay \\
\hline 416 & Mexico & Jordan \\
\hline 415 & Jordan & Mexico, Trinidad and Tobago \\
\hline 410 & Trinidad and Tobago & Jordan, Brazil \\
\hline 405 & Brazil & Trinidad and Tobago, Colombia, Montenegro, Argentina, Tunisia, Kazakhstan \\
\hline 402 & Colombia & Brazil, Montenegro, Argentina, Tunisia, Kazakhstan \\
\hline 401 & Montenegro & Brazil, Colombia, Argentina, Tunisia, Kazakhstan \\
\hline 401 & Argentina & Brazil, Colombia, Montenegro, Tunisia, Kazakhstan, Albania \\
\hline 401 & Tunisia & Brazil, Colombia, Montenegro, Argentina, Kazakhstan \\
\hline 400 & Kazakhstan & Brazil, Colombia, Montenegro, Argentina, Tunisia, Albania \\
\hline 391 & Albania & Argentina, Kazakhstan, Indonesia \\
\hline 383 & Indonesia & Albania, Qatar, Panama, Azerbaijan \\
\hline 379 & Qatar & Indonesia, Panama \\
\hline 376 & Panama & Indonesia, Qatar, Azerbaijan, Peru \\
\hline 373 & Azerbaijan & Indonesia, Panama, Peru \\
\hline 369 & Peru & Panama, Azerbaijan \\
\hline 330 & Kyrgyzstan & \\
\hline
\end{tabular}

Source: OECD, PISA 2009 Database.

StatLink 到s $\mathrm{http}: / / \mathrm{dx}$.doi.org/10.1787/888932343152 


\section{Figure A.4}

\section{Relationship between school average socio-economic background and school resources}

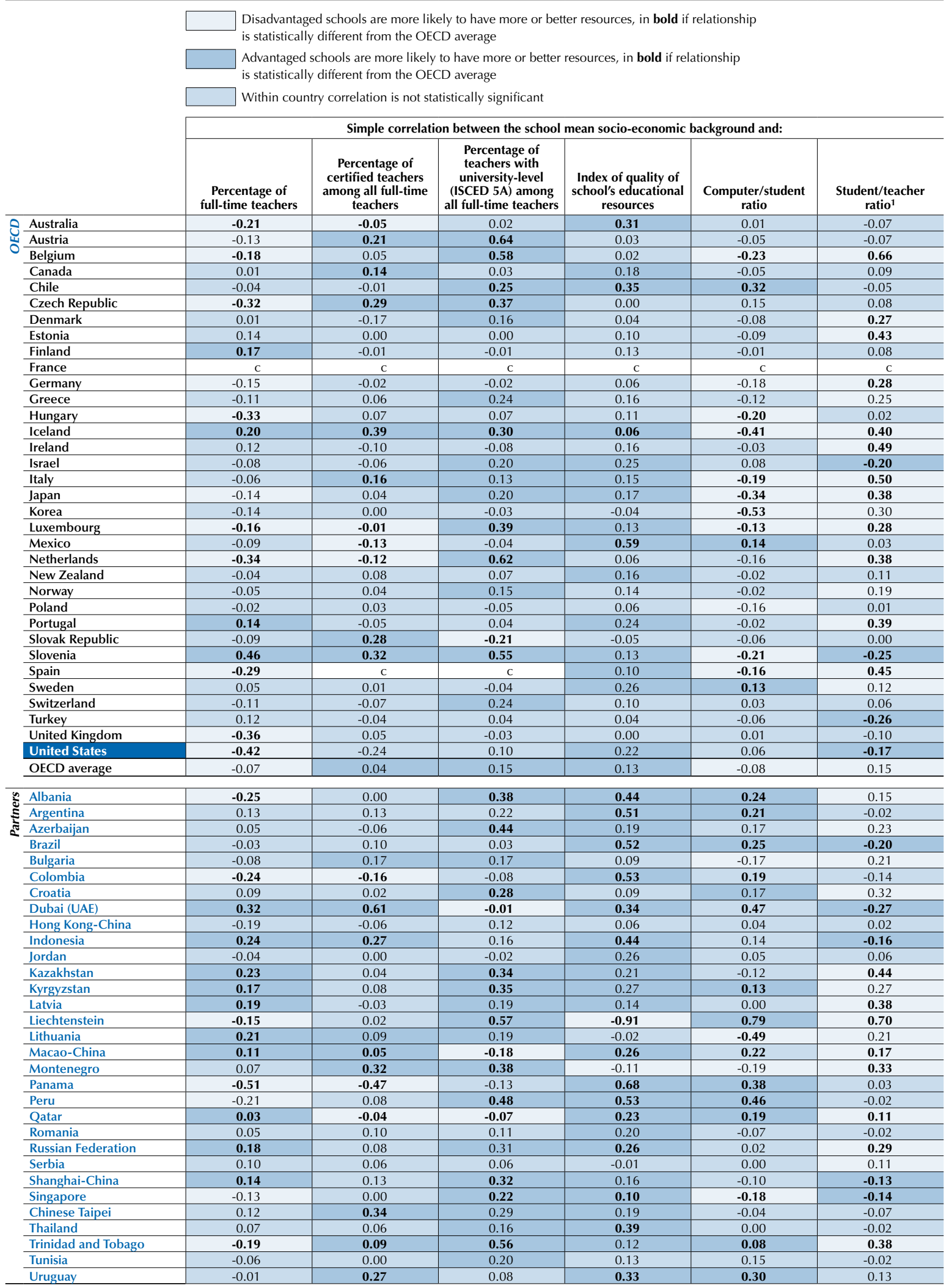

1. In contrast to the other columns, negative correlations indicate more favourable characteristics for advantaged students.

Source: OECD, PISA 2009 Database, Table II.2.2

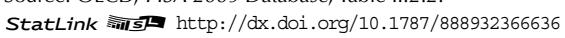




\section{Figure A.5}

\section{School principals' views of how teacher behaviour affects students' learning}

Index of teacher-related factors affecting school climate based on school principals' reports

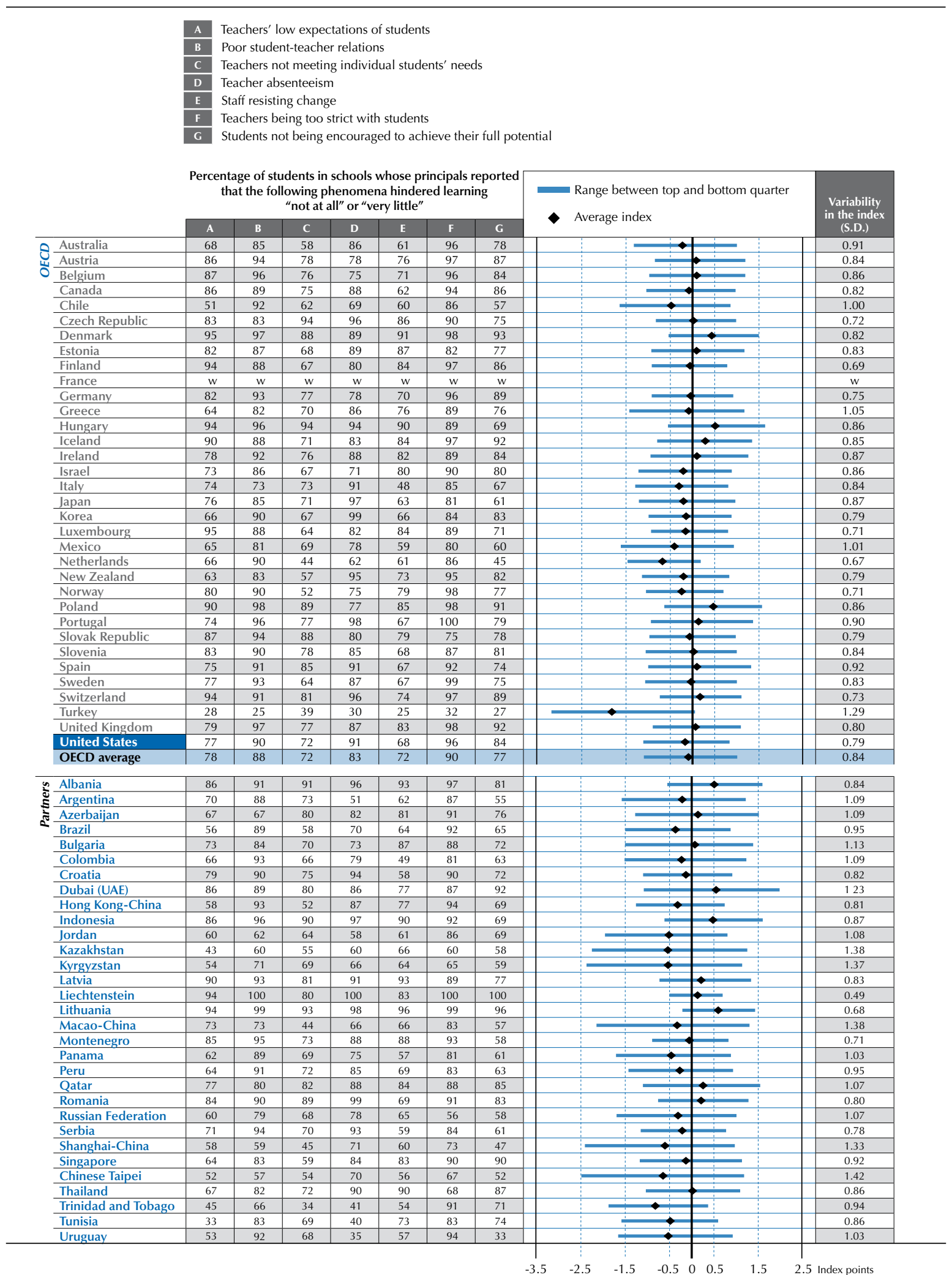

Note: Higher values on the index indicate a positive teacher behaviour.

Source: OECD, PISA 2009 Database, Table IV.4.5.

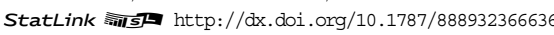




\section{Figure A.6}

\section{School principals' views of their involvement in school matters}

Index of school principal's leadership based on school principals' reports

A I make sure that the professional development activities of teachers are in accordance with the teaching goals of the school I ensure that teachers work according to the school's educational goals.

I observe instruction in classrooms.

D I use student performance results to develop the school's educational goals.

I give teachers suggestions as to how they can improve their teaching.

I monitor students' work

G When a teacher has problems in his/her classroom, I take the initiative to discuss matters.

H I inform teachers about possibilities for updating their knowledge and skills.

I check to see whether classroom activities are in keeping with our educational goals.

I take exam results into account in decisions regarding curriculum development

I ensure that there is clarity concerning the responsibility for co-ordinating the curriculum.

When a teacher brings up a classroom problem, we solve the problem together.

I pay attention to disruptive behaviour in classrooms.

I take over lessons from teachers who are unexpectedly absent.
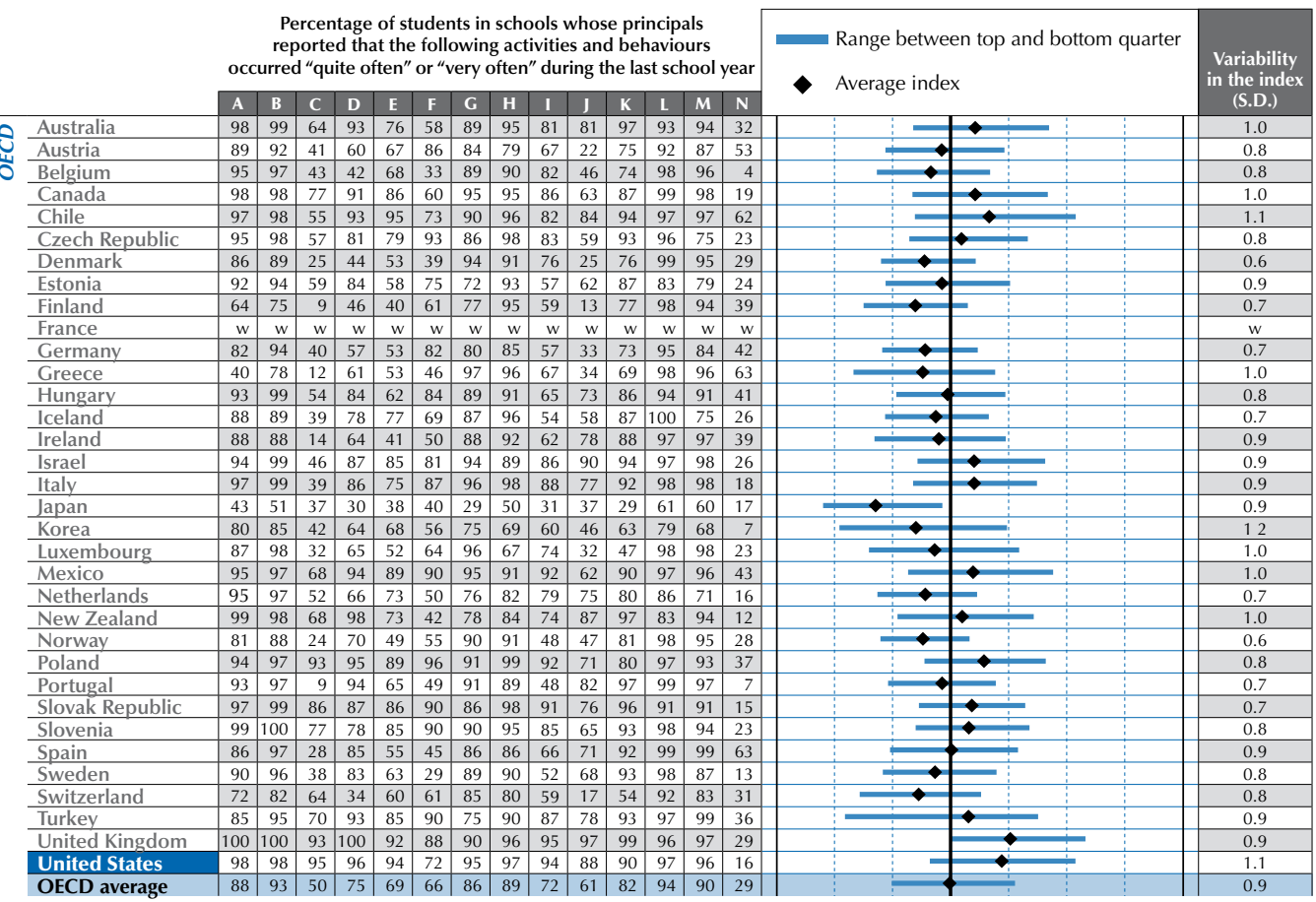

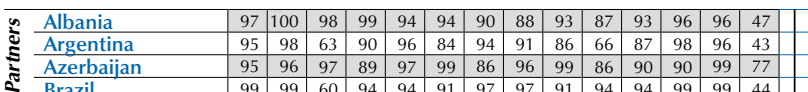

\begin{tabular}{l|r|r|r|r|r|r|r|r|r|r|r|r|r|r|r|r|r|}
\hline Azerbaijan & 95 & 96 & 97 & 89 & 97 & 99 & 86 & 96 & 99 & 86 & 90 & 90 & 99 & 77 \\
\hline Brazil & 99 & 99 & 60 & 94 & 94 & 91 & 97 & 97 & 91 & 94 & 94 & 99 & 99 & 44 \\
\hline Colgaria & 100 & 100 & 92 & 95 & 79 & 93 & 87 & 98 & 94 & 71 & 98 & 91 & 96 & 29 \\
\hline Crombia & 98 & 99 & 45 & 85 & 92 & 88 & 90 & 96 & 82 & 87 & 92 & 96 & 96 & 31
\end{tabular}

Colombia

Dubai (UAE)

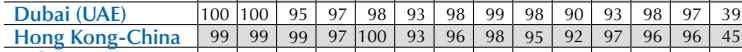

$\begin{array}{llllllllllll} & \end{array}$

Jordan

Kazakhstan

Kyrgyzstan

Latvia

Liechtenstein

Lithuania

Macao-China

Montenegro

Panama

Peru

Qatar

(1)

Romania

Russian Fe

Shanghai-China

Singapore

Chinese Taipei

Thailand

Trinidad and Tobago

Tunisia

\begin{tabular}{|r|r|r|r|r|r|r|r|c|c|c|c|c|c|}
94 & 98 & 70 & 80 & 92 & 96 & 96 & 95 & 98 & 76 & 95 & 99 & 100 & 19 \\
100 & 100 & 95 & 97 & 98 & 93 & 98 & 99 & 98 & 90 & 93 & 98 & 97 & 39 \\
\hline 99 & 99 & 99 & 97 & 100 & 93 & 96 & 98 & 95 & 92 & 97 & 96 & 96 & 45
\end{tabular}

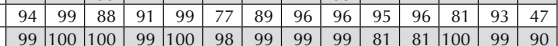

\begin{tabular}{|l|r|c|c|c|c|c|c|c|c|c|c|c|c|}
96 & 98 & 98 & 95 & 97 & 97 & 85 & 98 & 99 & 60 & 87 & 86 & 89 & 17 \\
\hline
\end{tabular}

\begin{tabular}{l|l|l|l|l|l|l|l|l|l|l|l|l|l|}
90 & 92 & 98 & 90 & 94 & 98 & 89 & 96 & 95 & 82 & 87 & 86 & 81 & 29 \\
\hline
\end{tabular}

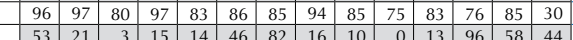

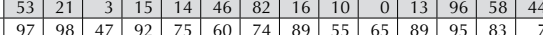

\begin{tabular}{r|r|rrrrrrrrrrrrrr|r|r|}
97 & 98 & 47 & 92 & 75 & 60 & 74 & 89 & 55 & 65 & 89 & 95 & 83 & 7 \\
100 & 100 & 88 & 74 & 82 & 86 & 93 & 76 & 86 & 52 & 88 & 90 & 90 & 45 \\
\hline
\end{tabular}

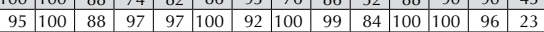

\begin{tabular}{|l|l|l|l|l|l|l|l|l|l|l|l|l|l|}
91 & 95 & 86 & 88 & 95 & 84 & 90 & 92 & 95 & 85 & 88 & 97 & 94 & 43 \\
\hline
\end{tabular}

\begin{tabular}{|r|r|r|r|l|l|l|l|l|l|l|l|l|l|}
94 & 98 & 86 & 88 & 93 & 80 & 80 & 94 & 92 & 84 & 91 & 91 & 95 & 45 \\
\hline 96 & 100 & 100 & 98 & 97 & 94 & 95 & 95 & 98 & 84 & 87 & 96 & 98 & 28 \\
\hline
\end{tabular}

\begin{tabular}{|r|r|r|r|r|r|r|r|r|r|r|r|r|r|}
\hline 96 & 100 & 100 & 98 & 97 & 94 & 95 & 95 & 98 & 84 & 87 & 96 & 98 & 28 \\
\hline 98 & 100 & 87 & 98 & 90 & 90 & 96 & 98 & 99 & 91 & 99 & 100 & 99 & 40 \\
\hline
\end{tabular}

\begin{tabular}{|l|l|l|l|l|l|l|l|l|l|l|l|l|l|}
99 & 99 & 92 & 89 & 87 & 95 & 80 & 99 & 97 & 55 & 97 & 96 & 86 & 31 \\
\hline 97 & 100 & 67 & 90 & 91 & 82 & 97 & 99 & 87 & 93 & 91 & 97 & 97 & 44
\end{tabular}

\begin{tabular}{l|l|l|l|l|l|l|l|l|l|l|l|l|l|}
97 & 100 & 67 & 90 & 91 & 82 & 97 & 99 & 87 & 93 & 91 & 97 & 97 & 44 \\
\hline 98 & 98 & 94 & 57 & 99 & 69 & 91 & 93 & 96 & 70 & 98 & 99 & 89 & 14 \\
\hline
\end{tabular}

\begin{tabular}{rrrrrrrrr|r|r|r|r|r|r|r}
98 & 98 & 94 & 57 & 99 & 69 & 91 & 93 & 96 & 70 & 98 & 99 & 89 & 14 \\
100 & 100 & 80 & 99 & 94 & 66 & 93 & 93 & 93 & 98 & 98 & 97 & 96 & 8 \\
\hline
\end{tabular}

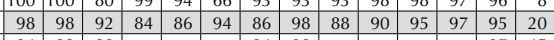

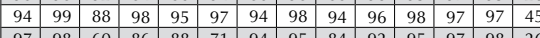
\begin{tabular}{|llllllllllllllllll|l|l|}
84 & 97 & 60 & 86 & 88 & 71 & 94 & 95 & 84 & 92 & 95 & 97 & 98 & 26 \\
\hline 85 & 98 & 89 & 90 & 90 & 60 & 97 & 82 & 84 & 40 & 59 & 99 & 99 & 45 \\
\hline
\end{tabular}

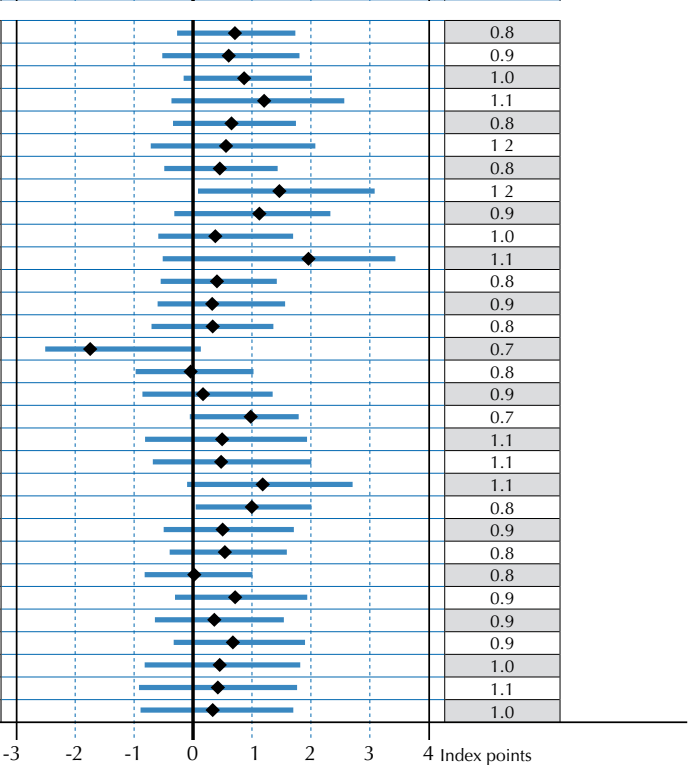

Note: Higher values on the index indicate greater involvement of school principals in school matters.

Source: OECD, PISA 2009 Database, Table IV.4.8.

StatLink 年开S http://dx.doi.org/10.1787/888932366636 


\section{Figure A.7}

Selected characteristics of school systems with reading performance above the OECD average

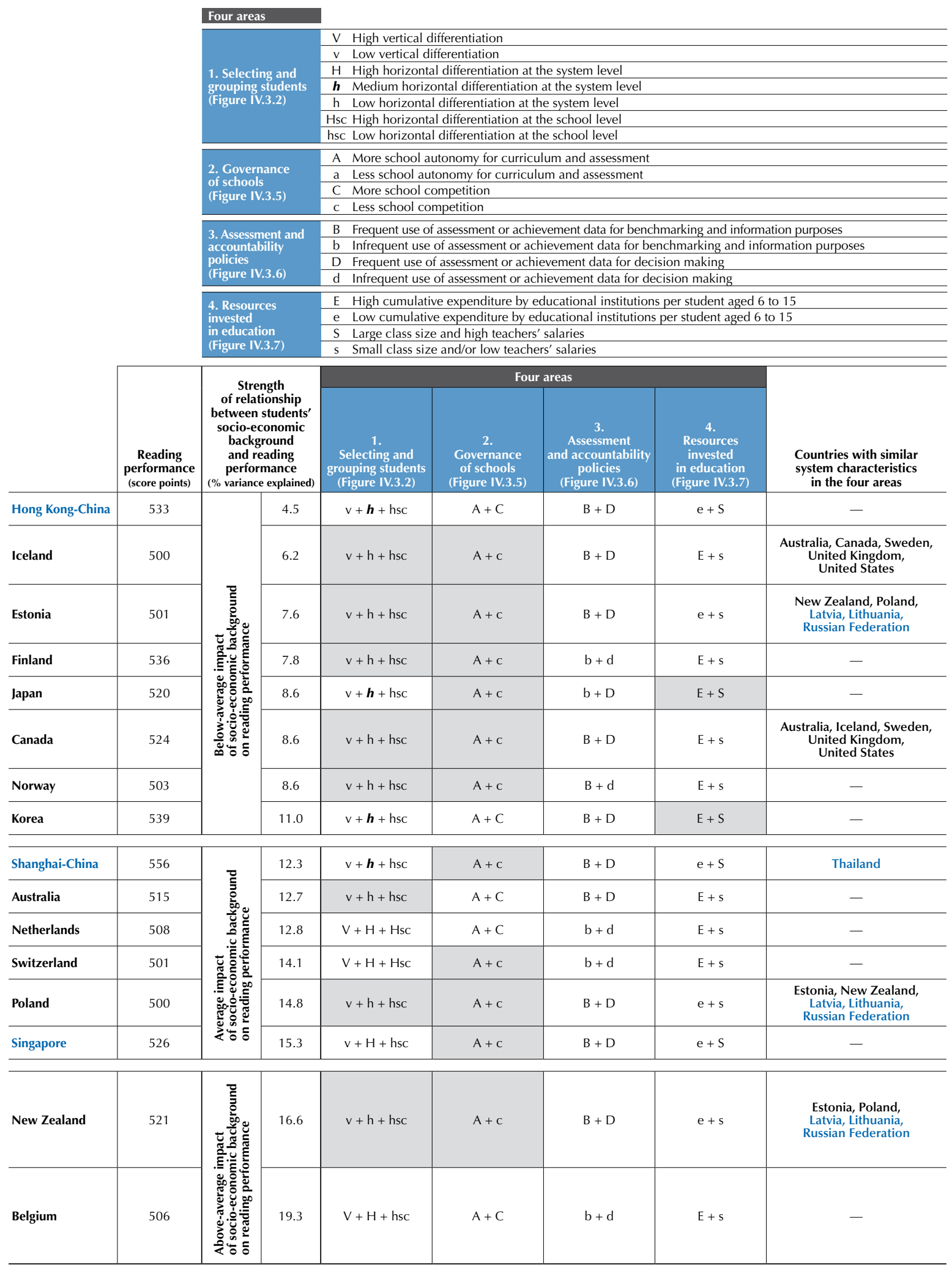

Note: Cells shaded in grey are the most prevailing patterns among school systems with above-average reading performance and below-average impact of socio-economic background on reading performance within each of the four areas.

Source: OECD, PISA 2009 Database, Tables IV.1.1a and IV.1.1b.

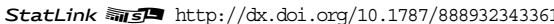




\section{Figure A.8}

\section{Students' views of how conducive classrooms are to learning}

Index of disciplinary climate based on students' reports

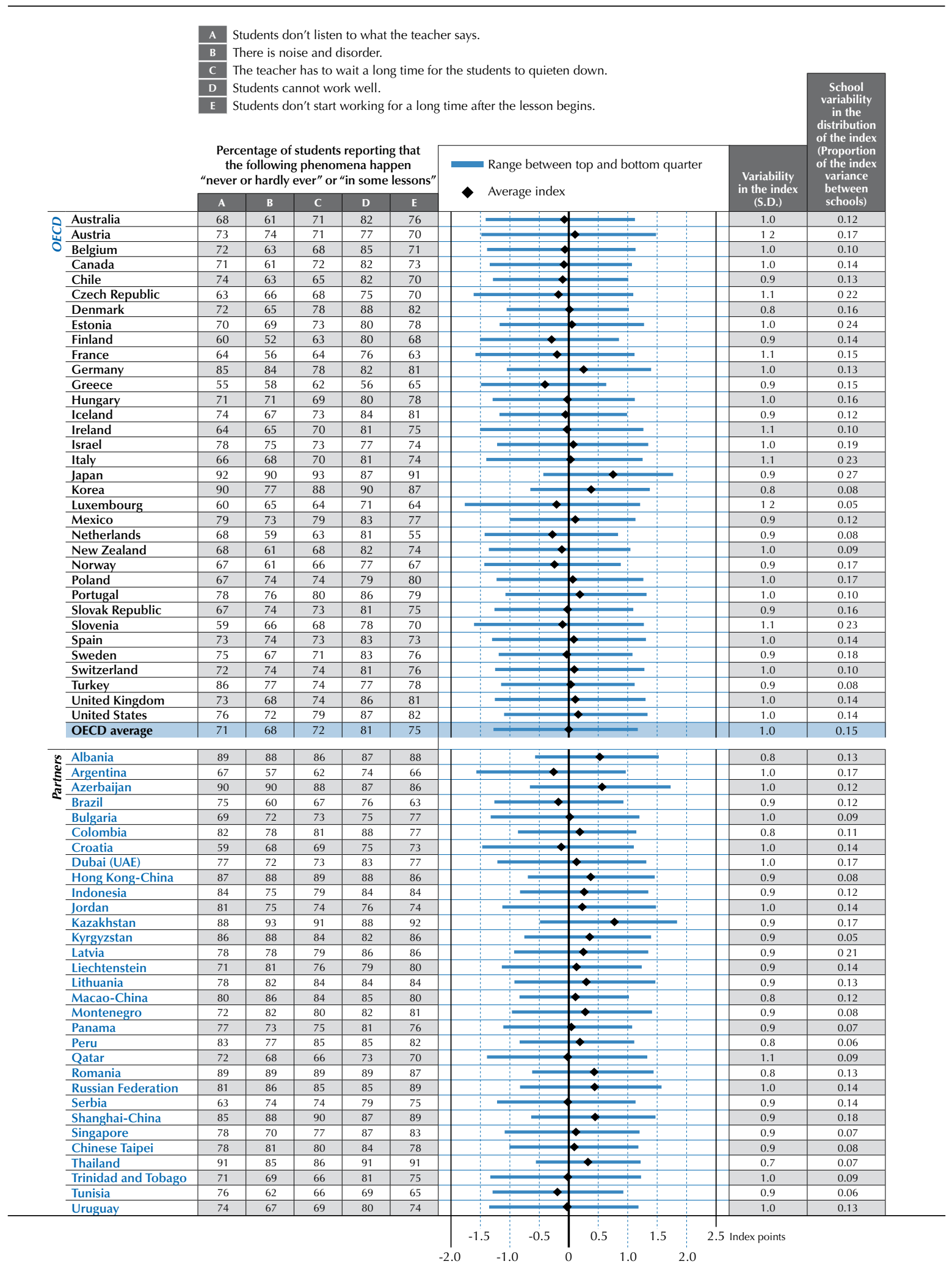

Note: Higher values on the index indicate a better disciplinary climate.

Source: OECD, PISA 2009 Database, Table IV.4.2.

StatLink 年15 


\section{Figure A.9}

\section{Students' views of how well teachers motivate them to read}

Index of teachers' stimulation of students' reading engagement based on students' reports

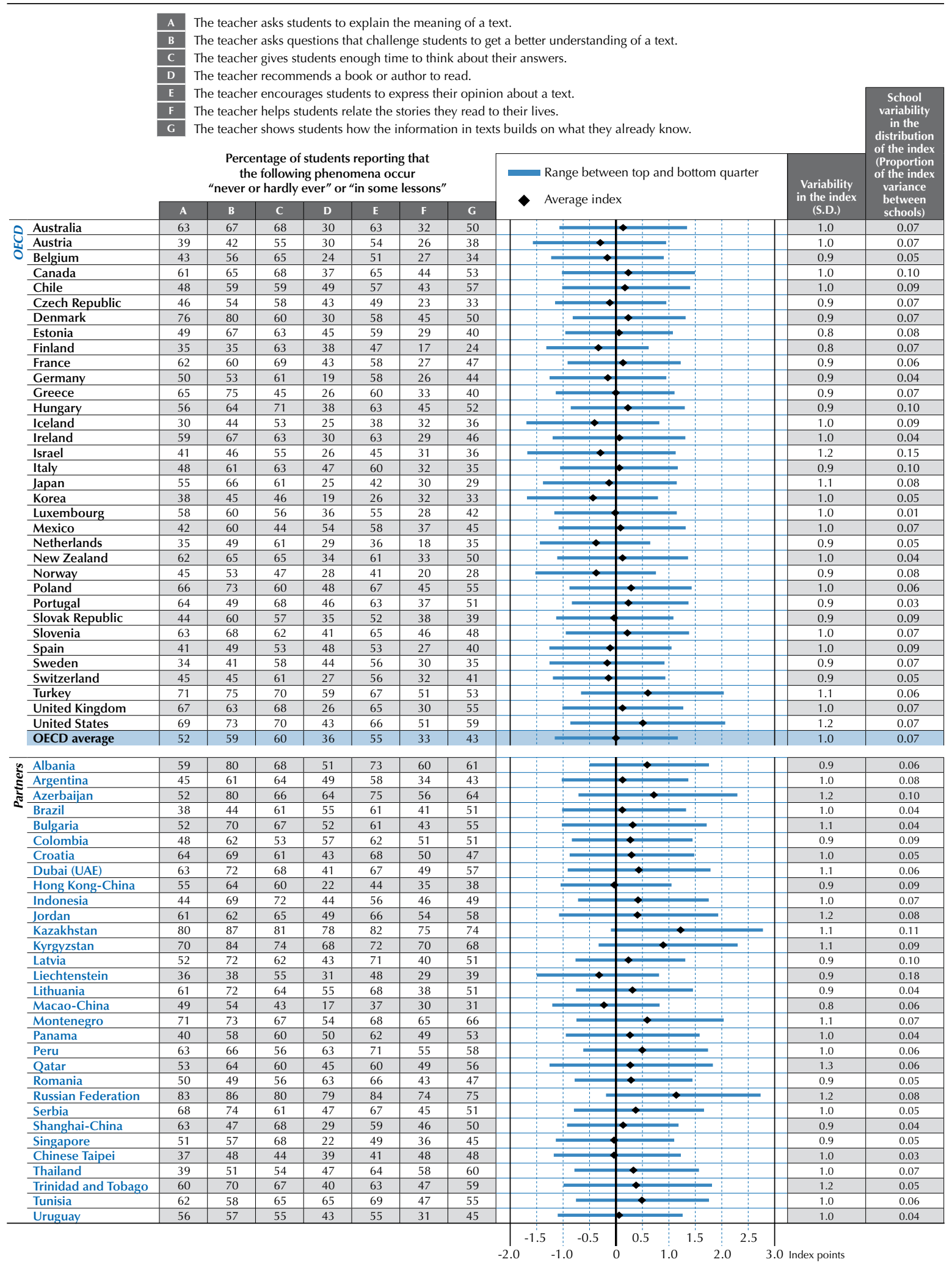

Note: Higher values on the index indicate higher teacher stimulation of reading engagement.

Source: OECD, PISA 2009 Database, Table IV.4.3.

StatLink 需政 http://dx.doi.org/10.1787/888932343418 


\section{Figure A.10}

School principals' views of how teacher behaviour affects students' learning

Index of teacher-related factors affecting school climate based on school principals' reports

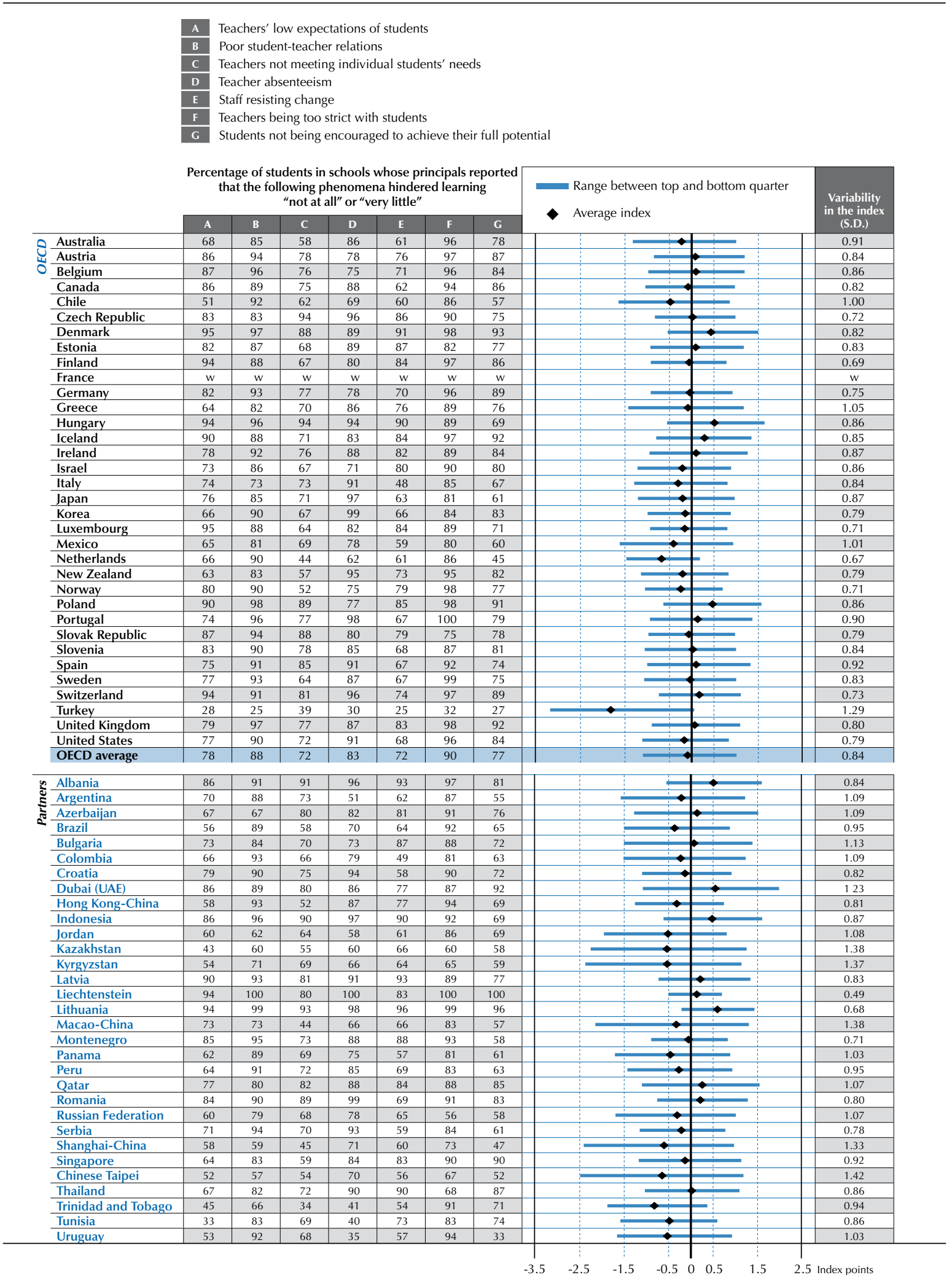

Note: Higher values on the index indicate a positive teacher behaviour.

Source: OECD, PISA 2009 Database, Table IV.4.5.

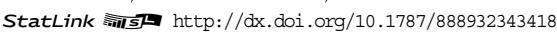




\section{Figure A.11}

\section{How much autonomy individual schools have over resource allocation}

Percentage of students in schools whose principals reported that only "principals and/or teachers", only "regional and/or national education authority" or both "principals and/or teachers" and "regional and/or national education authority" have a considerable responsibility for the following tasks
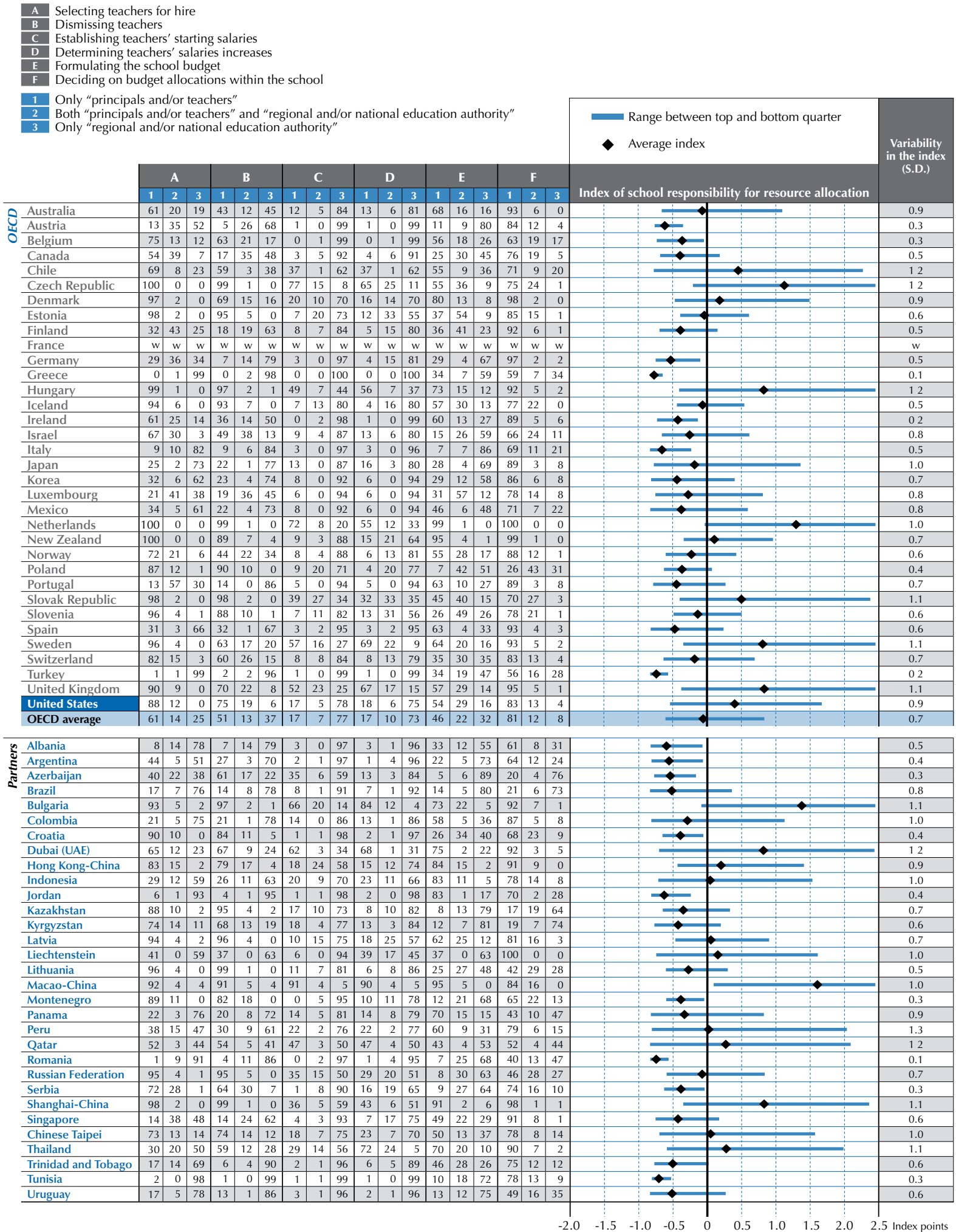

Source: OECD, PISA 2009 Database, Table IV.3.5

StatLink 解络 http://dx.doi.org/10.1787/888932366636 


\section{Figure A.12}

\section{How much autonomy individual schools have over curricula and assessments}

Percentage of students in schools whose principals reported that only "principals and/or teachers", only "regional and/or national education authority" or both "principals and/or teachers" and "regional and/or national education authority" have a considerable responsibility for the following tasks

A Establishing student assessment policies

B Choosing which textbooks are used

Determining course content

D Deciding which courses are offered

1 Only "principals and/or teachers"

2 Both "principals and/or teachers" and "regional and/or national education authority" Only "regional and/or national education authority"

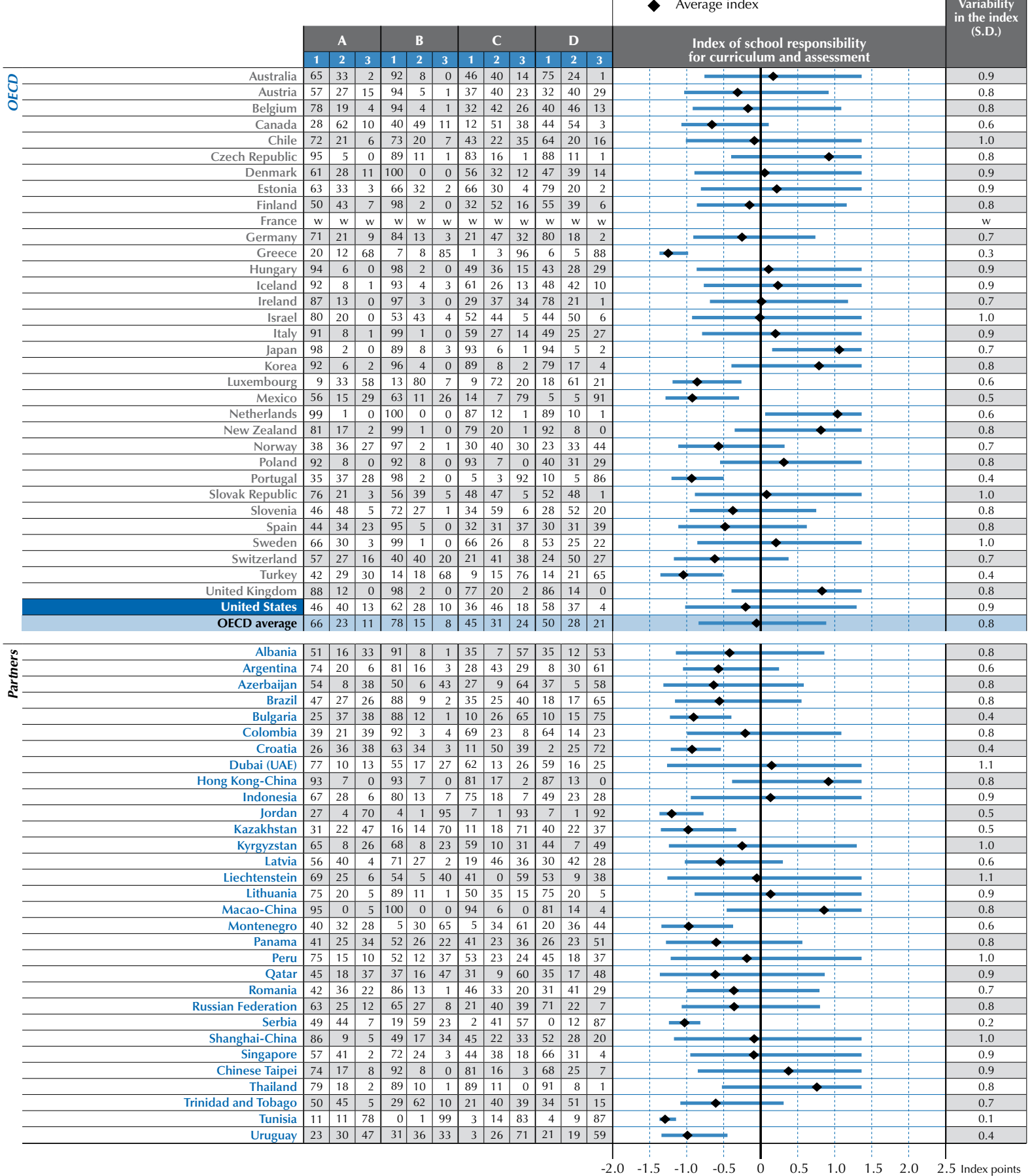

Source: OECD, PISA 2009 Database, Table IV.3.6.

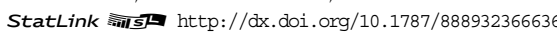


Table A.1

Average class size, by type of institution and level of education (2008)

Calculations based on number of students and number of classes

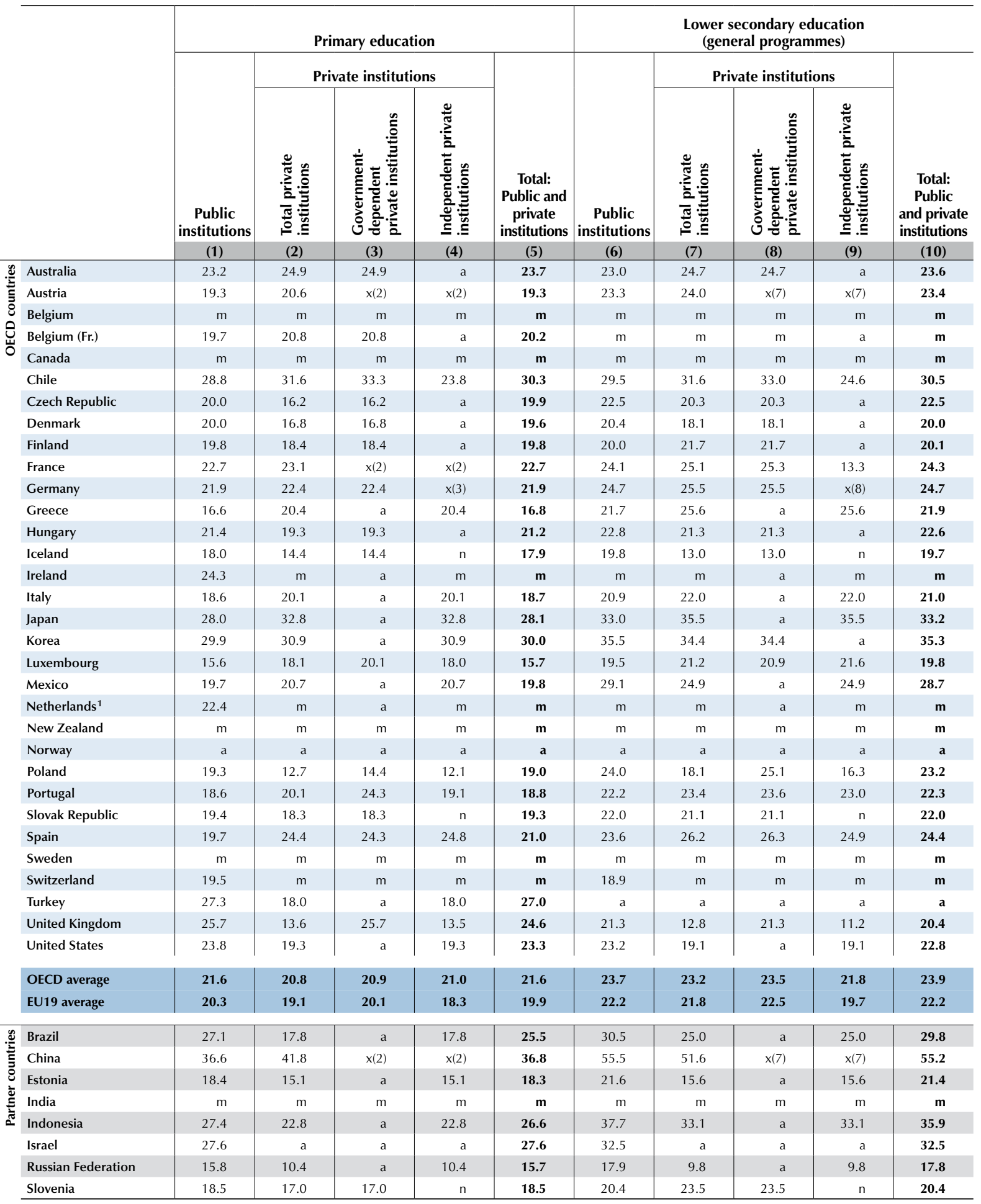

1. Year of reference 2006 .

Source: Education at a Glance 2010: OECD Indicators, OECD Publishing. India, Indonesia: UNESCO Institute for Statistics (World Education Indicators Programme). China: Based on the Educational Statistics Yearbook in China 2008. See Annex 3 for notes (www.oecd.org/edu/eag2010).

StatLink 세그 http://dx.doi.org/10.1787/888932310491 


\section{Table A.2}

Ratio of students to teaching staff in educational institutions (2008)

By level of education, calculations based on full-time equivalents

\begin{tabular}{|c|c|c|c|c|c|c|c|c|c|c|c|}
\hline & & \multicolumn{2}{|c|}{ Pre-primary education } & & \multicolumn{3}{|c|}{ Secondary education } & \multirow[b]{2}{*}{$\begin{array}{c}\text { Post- } \\
\text { secondary } \\
\text { non- } \\
\text { tertiary } \\
\text { education }\end{array}$} & \multicolumn{3}{|c|}{ Tertiary education } \\
\hline & & 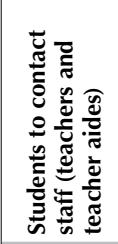 & 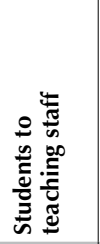 & $\begin{array}{c}\text { Primary } \\
\text { education }\end{array}$ & 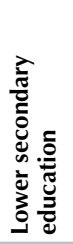 & 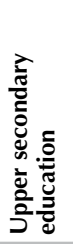 & 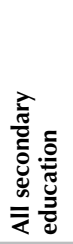 & & 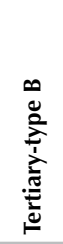 & 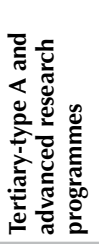 & 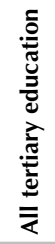 \\
\hline & & (1) & $(2)$ & (3) & (4) & (5) & (6) & (7) & $(8)$ & (9) & (10) \\
\hline \multirow{33}{*}{ 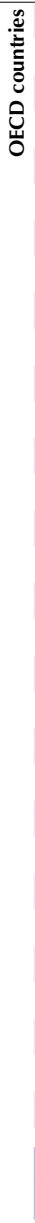 } & Australia $^{1,2}$ & $\mathrm{~m}$ & $\mathrm{~m}$ & 15.8 & $x(6)$ & $\mathrm{x}(6)$ & 12.0 & $\mathrm{~m}$ & $\mathrm{~m}$ & 15.2 & $\mathrm{~m}$ \\
\hline & Austria & 12.0 & 16.3 & 12.9 & 9.9 & 10.5 & 10.2 & 10.6 & $x(10)$ & $x(10)$ & 14.6 \\
\hline & Belgium $^{3}$ & 15.9 & 15.9 & 12.6 & 8.1 & 10.8 & 9.9 & $\mathrm{x}(5)$ & $x(10)$ & $x(10)$ & 19.0 \\
\hline & Canada $^{2}$ & $\mathrm{~m}$ & $x(6)$ & $x(6)$ & $x(6)$ & $x(6)$ & 16.3 & $\mathrm{~m}$ & $\mathrm{~m}$ & m & $\mathrm{m}$ \\
\hline & Chile & 11.9 & 13.7 & 24.1 & 24.1 & 25.2 & 24.8 & a & 74.2 & 21.6 & 30.0 \\
\hline & Czech Republic & 13.5 & 13.7 & 18.1 & 11.8 & 12.2 & 12.0 & 18.2 & 16.2 & 19.4 & 19.1 \\
\hline & Denmark & $\mathrm{m}$ & 6.2 & $\mathrm{x}(4)$ & 10.1 & $\mathrm{~m}$ & $\mathrm{~m}$ & $\mathrm{~m}$ & $\mathrm{~m}$ & $\mathrm{~m}$ & $\mathrm{~m}$ \\
\hline & Finland & $\mathrm{m}$ & 11.4 & 14.4 & 10.6 & 15.9 & 13.6 & $\mathrm{x}(5)$ & $\mathrm{n}$ & 15.8 & 15.8 \\
\hline & France $^{3}$ & 19.0 & 19.0 & 19.9 & 14.6 & 9.4 & 11.9 & $x(8)$ & 16.7 & 16.1 & 16.2 \\
\hline & Germany & 10.7 & 13.8 & 18.0 & 15.0 & 14.0 & 14.7 & 14.8 & 12.0 & 11.5 & 11.5 \\
\hline & Greece & $\mathrm{m}$ & $\mathrm{m}$ & $\mathrm{m}$ & $\mathrm{m}$ & $\mathrm{m}$ & $\mathrm{m}$ & $\mathrm{m}$ & $\mathrm{m}$ & $\mathrm{m}$ & $\mathrm{m}$ \\
\hline & Hungary & $\mathrm{m}$ & 10.9 & 10.6 & 10.9 & 12.3 & 11.6 & 13.1 & 19.5 & 17.0 & 17.1 \\
\hline & Iceland & 7.2 & 7.2 & $x(4)$ & 10.0 & 10.6 & 10.2 & $x(5,10)$ & $x(10)$ & $x(10)$ & 10.1 \\
\hline & Ireland $^{2}$ & 4.7 & 10.3 & 17.8 & $x(6)$ & $x(6)$ & 12.8 & $x(6)$ & $x(10)$ & $x(10)$ & 15.9 \\
\hline & Italy ${ }^{2}$ & 11.2 & 11.2 & 10.6 & 9.7 & 11.8 & 10.8 & $\mathrm{~m}$ & 7.5 & 19.7 & 19.5 \\
\hline & Japan & 15.8 & 16.5 & 18.8 & 14.7 & 12.3 & 13.4 & $x(5,10)$ & 7.5 & 11.8 & 10.4 \\
\hline & Korea & 17.9 & 17.9 & 24.1 & 20.2 & 16.5 & 18.2 & $\mathrm{a}$ & $\mathrm{m}$ & $\mathrm{m}$ & $\mathrm{m}$ \\
\hline & Luxembourg ${ }^{2}$ & $\mathrm{~m}$ & 12.2 & 12.1 & $x(6)$ & $x(6)$ & 9.1 & $\mathrm{~m}$ & $\mathrm{~m}$ & $\mathrm{~m}$ & $\mathrm{~m}$ \\
\hline & Mexico & 27.1 & 27.1 & 28.0 & 33.9 & 25.8 & 30.7 & $\mathrm{a}$ & 13.3 & 14.5 & 14.4 \\
\hline & Netherlands ${ }^{2}$ & $\mathrm{~m}$ & $x(3)$ & 15.8 & $x(6)$ & $x(6)$ & 15.8 & $x(6)$ & $\mathrm{n}$ & 14.9 & 14.9 \\
\hline & New Zealand & 9.6 & 9.6 & 17.1 & 16.2 & 12.8 & 14.5 & 17.1 & 17.3 & 17.9 & 17.8 \\
\hline & Norway ${ }^{2}$ & $\mathrm{~m}$ & $\mathrm{~m}$ & 10.8 & 10.1 & 9.9 & 10.0 & $x(5)$ & $x(10)$ & $x(10)$ & 9.3 \\
\hline & Poland & $\mathrm{m}$ & 18.8 & 10.5 & 12.9 & 12.2 & 12.5 & 14.1 & 11.5 & 16.8 & 16.7 \\
\hline & Portugal & $\mathrm{m}$ & 14.7 & 11.3 & 8.1 & 7.3 & 7.7 & $x(5,10)$ & $x(10)$ & $x(10)$ & 13.8 \\
\hline & Slovak Republic & 13.2 & 13.3 & 18.6 & 14.5 & 15.1 & 14.8 & 9.3 & 10.5 & 15.5 & 15.4 \\
\hline & Spain & $\mathrm{m}$ & 13.1 & 13.1 & 10.3 & 8.7 & 9.8 & $\mathrm{a}$ & 8.8 & 11.6 & 11.1 \\
\hline & Sweden & 6.1 & 6.1 & 12.2 & 11.4 & 14.7 & 13.1 & 12.5 & $x(10)$ & $x(10)$ & 8.5 \\
\hline & Switzerland ${ }^{1,2}$ & $\mathrm{~m}$ & 16.6 & 15.4 & 12.1 & 10.4 & 11.7 & $\mathrm{~m}$ & $\mathrm{~m}$ & $\mathrm{~m}$ & $\mathrm{~m}$ \\
\hline & Turkey & $\mathrm{m}$ & 27.1 & 24.4 & $\mathrm{a}$ & 17.0 & 17.0 & $\mathrm{a}$ & 80.8 & 20.0 & 25.7 \\
\hline & United Kingdom & 16.8 & 17.9 & 20.2 & 15.0 & 12.4 & 13.4 & $\mathrm{x}(5)$ & $x(10)$ & $x(10)$ & 16.9 \\
\hline & United States & 11.0 & 13.4 & 14.3 & 14.8 & 15.6 & 15.1 & 14.7 & $x(10)$ & $x(10)$ & 15.0 \\
\hline & OECD average & 13.1 & 14.4 & 16.4 & 13.7 & 13.5 & 13.7 & 13.8 & 19.7 & 16.2 & 15.8 \\
\hline & EU19 average & 12.3 & 13.2 & 14.6 & 11.5 & 12.0 & 12.0 & 13.2 & 12.8 & 15.8 & 15.4 \\
\hline \multirow{8}{*}{ 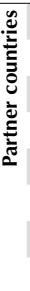 } & Brazil & 14.0 & 18.8 & 24.5 & 21.2 & 18.4 & 20.0 & $\mathrm{a}$ & $x(10)$ & $x(10)$ & 15.9 \\
\hline & China & $\mathrm{m}$ & 22.4 & 17.9 & 16.0 & 17.5 & 16.7 & $\mathrm{~m}$ & 10.1 & $\mathrm{~m}$ & $\mathrm{~m}$ \\
\hline & Estonia & $\mathrm{m}$ & $\mathrm{m}$ & 16.4 & 16.0 & 12.4 & 13.8 & $x(5)$ & $\mathrm{m}$ & $\mathrm{m}$ & $\mathrm{m}$ \\
\hline & India & $\mathrm{m}$ & $\mathrm{m}$ & $\mathrm{m}$ & $\mathrm{m}$ & $\mathrm{m}$ & $\mathrm{m}$ & $\mathrm{m}$ & $\mathrm{m}$ & $\mathrm{m}$ & $\mathrm{m}$ \\
\hline & Indonesia & $\mathrm{m}$ & 14.9 & 21.4 & 15.4 & 18.1 & 16.4 & a & $\mathrm{x}(10)$ & $x(10)$ & 17.6 \\
\hline & Israel $^{2}$ & 11.1 & 21.9 & 16.3 & 12.2 & 10.9 & 11.4 & $\mathrm{~m}$ & $\mathrm{~m}$ & $\mathrm{~m}$ & $\mathrm{~m}$ \\
\hline & Russian Federation ${ }^{2,4}$ & $\mathrm{~m}$ & $\mathrm{~m}$ & 17.3 & $x(6)$ & $x(6)$ & 8.7 & $x(6)$ & 10.2 & 13.5 & 12.6 \\
\hline & Slovenia & 9.4 & 9.4 & 15.8 & 8.9 & 13.7 & 11.3 & $x(5)$ & $x(10)$ & $x(10)$ & 20.8 \\
\hline
\end{tabular}

1. Includes only general programmes in upper secondary education.

2. Public institutions only (for Australia, for tertiary-type A and advanced research programmes only; for Ireland, at pre-primary and secondary levels only; for Italy, from pre-primary to secondary level; for Israel, at pre-primary level only; for the Russian Federation, at primary level only).

3. Excludes independent private institutions.

4. Excludes part-time personnel in public institutions at lower secondary and general upper secondary levels.

Source: Education at a Glance 2010: OECD Indicators, OECD Publishing. India, Indonesia: UNESCO Institute for Statistics (World Education Indicators Programme). China: Based on the Educational Statistics Yearbook in China 2008. See Annex 3 for notes (www.oecd.org/edu/eag2010).

StatLink 제매 http://dx.doi.org/10.1787/888932310491 
Table A.3 (1/2)

Teachers' salaries (2008)

Annual statutory teachers' salaries in public institutions at starting salary, after 15 years of experience and at the top of the scale, by level of education, in equivalent USD converted using PPPS

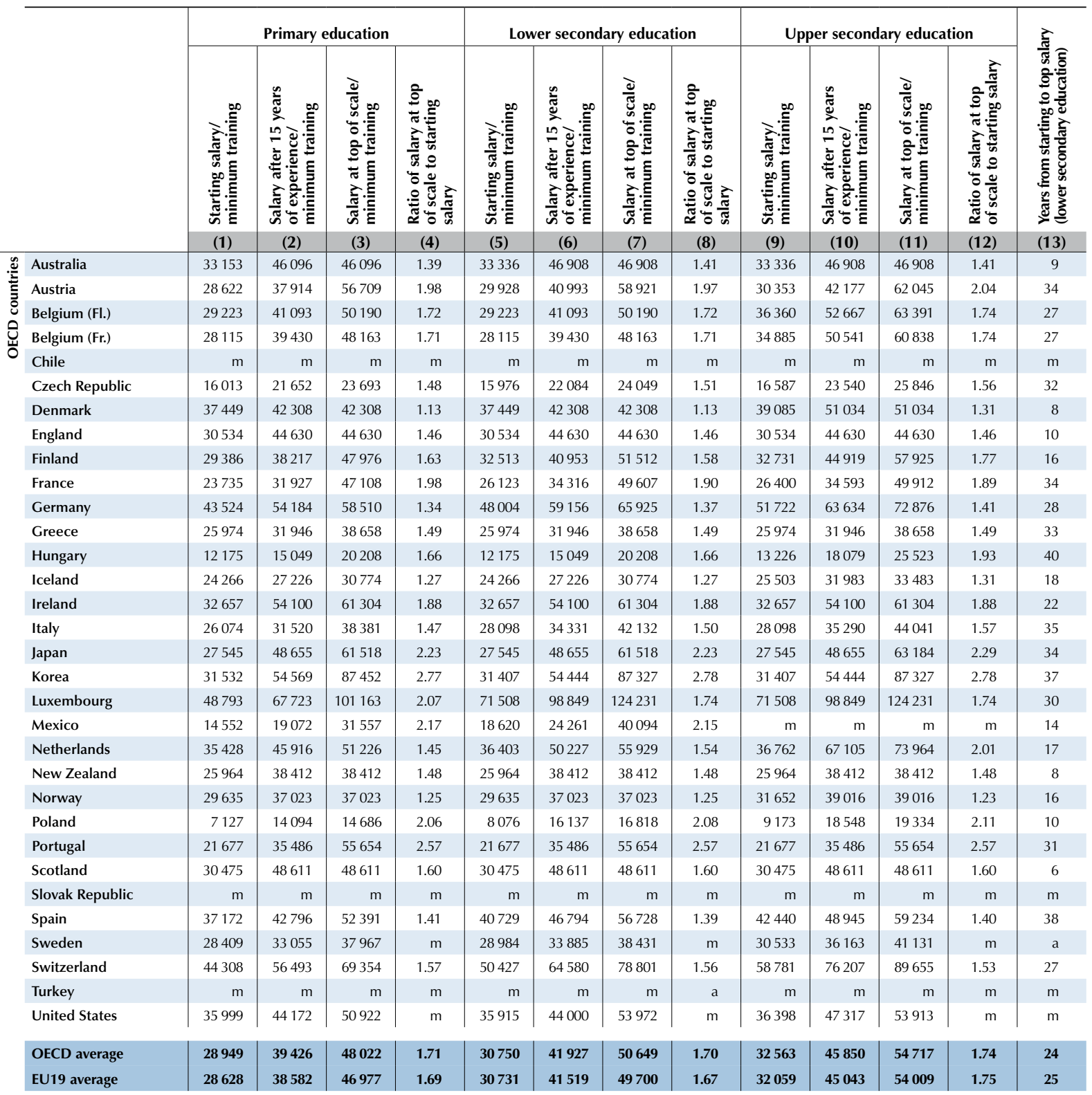

\begin{tabular}{|c|c|c|c|c|c|c|c|c|c|c|c|c|c|}
\hline Brazil & $\mathrm{m}$ & $\mathrm{m}$ & $\mathrm{m}$ & $\mathrm{m}$ & $\mathrm{m}$ & $\mathrm{m}$ & $\mathrm{m}$ & $\mathrm{m}$ & $\mathrm{m}$ & $\mathrm{m}$ & $\mathrm{m}$ & $\mathrm{m}$ & $\mathrm{m}$ \\
\hline China & $\mathrm{m}$ & $\mathrm{m}$ & $\mathrm{m}$ & $\mathrm{m}$ & $\mathrm{m}$ & $\mathrm{m}$ & $\mathrm{m}$ & $\mathrm{m}$ & $\mathrm{m}$ & $\mathrm{m}$ & $\mathrm{m}$ & $\mathrm{m}$ & $\mathrm{m}$ \\
\hline Estonia & 11981 & 12687 & 17510 & 1.46 & 11981 & 12687 & 17510 & 1.46 & 11981 & 12687 & 17510 & 1.46 & 7 \\
\hline India & $\mathrm{m}$ & $\mathrm{m}$ & $\mathrm{m}$ & $\mathrm{m}$ & $\mathrm{m}$ & $\mathrm{m}$ & $\mathrm{m}$ & $\mathrm{m}$ & $\mathrm{m}$ & $\mathrm{m}$ & $\mathrm{m}$ & $\mathrm{m}$ & $\mathrm{m}$ \\
\hline Indonesia & 1617 & 2046 & 2331 & 1.44 & 1723 & 2331 & 2532 & 1.47 & 1995 & 2582 & 2813 & 1.41 & 32 \\
\hline Israel & 18199 & 19868 & 27680 & 1.52 & 18199 & 22410 & 27680 & 1.52 & 18199 & 22410 & 27680 & 1.52 & 36 \\
\hline Russian Federation & $\mathrm{m}$ & $\mathrm{m}$ & $\mathrm{m}$ & $\mathrm{m}$ & $\mathrm{m}$ & $\mathrm{m}$ & $\mathrm{m}$ & $\mathrm{m}$ & $\mathrm{m}$ & $\mathrm{m}$ & $\mathrm{m}$ & $\mathrm{m}$ & $\mathrm{m}$ \\
\hline Slovenia & 27470 & 32075 & 33967 & 1.24 & 27470 & 32075 & 33967 & 1.24 & 27470 & 32075 & 33967 & 1.24 & 13 \\
\hline
\end{tabular}

Note: Ratio of salary at the top of the scale to starting salary has not been calculated for Sweden and the United States because the underlying salaries are estimates derived from actual rather than statutory salaries.

Source: Education at a Glance 2010: OECD Indicators, OECD Publishing. China, India and Indonesia: UNESCO Institute for Statistics (World Education Indicators Programme). See Annex 3 for notes (www.oecd.org/edu/eag2010).

StatLink 젶ㄴ http://dx.doi.org/10.1787/888932310510 
Table A.3 (2/2)

Teachers' salaries (2008)

Annual statutory teachers' salaries in public institutions at starting salary, after 15 years of experience and at the top of the scale, by level of education, in equivalent USD converted using PPPS

\begin{tabular}{|c|c|c|c|c|c|c|c|c|c|c|}
\hline & \multicolumn{3}{|c|}{$\begin{array}{c}\text { Ratio of salary } \\
\text { after } 15 \text { years of experience } \\
\text { (minimum training) to GDP } \\
\text { per capita }\end{array}$} & \multicolumn{3}{|c|}{$\begin{array}{c}\text { Ratio of salary after } \\
15 \text { years of experience } \\
\text { (minimum training) to earnings } \\
\text { for full-time full-year workers with } \\
\text { tertiary education aged } 25 \text { to } 64\end{array}$} & \multicolumn{3}{|c|}{$\begin{array}{l}\text { Salary per hour } \\
\text { of net contact (teaching) time } \\
\text { after } 15 \text { years of experience }\end{array}$} & \multirow{2}{*}{$\begin{array}{l}\text { Ratio of salary per } \\
\text { teaching hour of } \\
\text { upper secondary } \\
\text { to primary teachers } \\
\text { (after } 15 \text { years } \\
\text { of experience) }\end{array}$} \\
\hline & 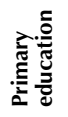 & 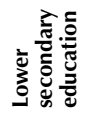 & 竎. & 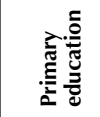 & 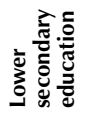 & 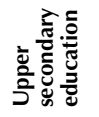 & 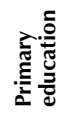 & 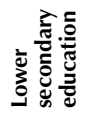 & 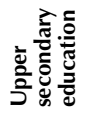 & \\
\hline & (14) & (15) & (16) & (17) & (18) & (19) & (20) & (21) & $(22)$ & (23) \\
\hline Australia $^{1}$ & 1.25 & 1.27 & 1.27 & 0.93 & 0.94 & 0.94 & 53 & 58 & 58 & 1.10 \\
\hline Austria $^{1}$ & 1.02 & 1.10 & 1.13 & 0.72 & 0.77 & 0.79 & 49 & 68 & 72 & 1.47 \\
\hline Belgium (FI.) $)^{1}$ & 1.17 & 1.17 & 1.51 & 0.90 & 0.90 & 1.14 & 51 & 59 & 81 & 1.60 \\
\hline Belgium (Fr. $)^{1}$ & 1.13 & 1.13 & 1.44 & 0.86 & 0.86 & 1.10 & 54 & 60 & 84 & 1.54 \\
\hline Chile & $\mathrm{m}$ & $\mathrm{m}$ & $\mathrm{m}$ & $\mathrm{m}$ & $\mathrm{m}$ & $\mathrm{m}$ & $\mathrm{m}$ & $\mathrm{m}$ & $\mathrm{m}$ & $\mathrm{m}$ \\
\hline Czech Republic ${ }^{2}$ & 0.89 & 0.91 & 0.97 & 0.49 & 0.50 & 0.53 & 25 & 35 & 39 & 1.52 \\
\hline Denmark $^{1}$ & 1.16 & 1.16 & 1.40 & 0.85 & 0.85 & 1.06 & 65 & 65 & 140 & 2.15 \\
\hline England $^{2}$ & 1.26 & 1.26 & 1.26 & 0.82 & 0.82 & 0.82 & 68 & 62 & 62 & 0.91 \\
\hline Finland $^{3}$ & 1.07 & 1.15 & 1.26 & 0.87 & 0.93 & 1.02 & 56 & 69 & 82 & 1.45 \\
\hline France $^{1}$ & 0.97 & 1.05 & 1.05 & 0.78 & 0.85 & 0.85 & 34 & 53 & 55 & 1.59 \\
\hline Germany $^{2}$ & 1.55 & 1.69 & 1.82 & 0.89 & 0.97 & 1.04 & 67 & 78 & 89 & 1.32 \\
\hline Greece $^{1}$ & 1.13 & 1.13 & 1.13 & 0.74 & 0.74 & 0.74 & 54 & 75 & 75 & 1.38 \\
\hline Hungary ${ }^{2}$ & 0.78 & 0.78 & 0.94 & 0.50 & 0.50 & 0.60 & 25 & 25 & 30 & 1.20 \\
\hline Iceland ${ }^{1}$ & 0.74 & 0.74 & 0.87 & 0.50 & 0.50 & 0.61 & 41 & 41 & 57 & 1.41 \\
\hline Ireland & 1.26 & 1.26 & 1.26 & $\mathrm{~m}$ & $\mathrm{~m}$ & $\mathrm{~m}$ & 59 & 74 & 74 & 1.25 \\
\hline Italy ${ }^{1}$ & 1.01 & 1.10 & 1.13 & 0.54 & 0.58 & 0.60 & 43 & 57 & 59 & 1.37 \\
\hline Japan & 1.44 & 1.44 & 1.44 & $\mathrm{~m}$ & $\mathrm{~m}$ & $\mathrm{~m}$ & 69 & 81 & 97 & 1.42 \\
\hline Korea $^{3}$ & 2.01 & 2.01 & 2.01 & 0.82 & 0.81 & 0.81 & 65 & 88 & 90 & 1.39 \\
\hline Luxembourg & 0.81 & 1.18 & 1.18 & $\mathrm{~m}$ & $\mathrm{~m}$ & $\mathrm{~m}$ & 92 & 156 & 156 & 1.70 \\
\hline Mexico & 1.33 & 1.69 & $\mathrm{~m}$ & $\mathrm{~m}$ & $\mathrm{~m}$ & $\mathrm{~m}$ & 24 & 23 & $\mathrm{~m}$ & $\mathrm{~m}$ \\
\hline Netherlands ${ }^{1}$ & 1.14 & 1.25 & 1.66 & 0.73 & 0.80 & 1.07 & 49 & 67 & 89 & 1.81 \\
\hline New Zealand ${ }^{2}$ & 1.42 & 1.42 & 1.42 & 0.97 & 0.97 & 0.97 & 39 & 40 & 40 & 1.04 \\
\hline Norway ${ }^{3}$ & 0.66 & 0.66 & 0.69 & 0.66 & 0.66 & 0.70 & 50 & 57 & 75 & 1.49 \\
\hline Poland $^{2}$ & 0.84 & 0.96 & 1.10 & 0.59 & 0.68 & 0.78 & 27 & 31 & 36 & 1.32 \\
\hline Portugal ${ }^{1}$ & 1.55 & 1.55 & 1.55 & 0.72 & 0.72 & 0.72 & 42 & 47 & 47 & 1.14 \\
\hline Scotland $^{2}$ & 1.38 & 1.38 & 1.38 & 0.89 & 0.89 & 0.89 & 57 & 57 & 57 & 1.00 \\
\hline Slovak Republic & $\mathrm{m}$ & $\mathrm{m}$ & $\mathrm{m}$ & $\mathrm{m}$ & $\mathrm{m}$ & $\mathrm{m}$ & $\mathrm{m}$ & $\mathrm{m}$ & $\mathrm{m}$ & $\mathrm{m}$ \\
\hline Spain $^{3}$ & 1.36 & 1.49 & 1.56 & 1.12 & 1.26 & 1.28 & 49 & 66 & 71 & 1.45 \\
\hline Sweden $^{3}$ & 0.90 & 0.92 & 0.98 & 0.90 & 0.93 & 0.99 & $\mathrm{~m}$ & $\mathrm{~m}$ & $\mathrm{~m}$ & $\mathrm{~m}$ \\
\hline Switzerland & 1.34 & 1.53 & 1.80 & $\mathrm{~m}$ & $\mathrm{~m}$ & $\mathrm{~m}$ & $\mathrm{~m}$ & $\mathrm{~m}$ & $\mathrm{~m}$ & $\mathrm{~m}$ \\
\hline Turkey & $\mathrm{m}$ & $\mathrm{m}$ & $\mathrm{m}$ & $\mathrm{m}$ & $\mathrm{m}$ & $\mathrm{m}$ & $\mathrm{m}$ & $\mathrm{m}$ & $\mathrm{m}$ & $\mathrm{m}$ \\
\hline United States ${ }^{2}$ & 0.94 & 0.94 & 1.01 & 0.60 & 0.60 & 0.65 & 40 & 41 & 45 & 1.12 \\
\hline OECD average & 1.16 & 1.22 & 1.29 & 0.77 & 0.79 & 0.86 & 50 & 60 & 71 & 1.39 \\
\hline EU19 average & 1.12 & 1.18 & 1.29 & 0.77 & 0.81 & 0.89 & 51 & 63 & 73 & 1.43 \\
\hline
\end{tabular}

\begin{tabular}{|c|c|c|c|c|c|c|c|c|c|c|}
\hline Brazil & $\mathrm{m}$ & $\mathrm{m}$ & $\mathrm{m}$ & $\mathrm{m}$ & $\mathrm{m}$ & $\mathrm{m}$ & $\mathrm{m}$ & $\mathrm{m}$ & $\mathrm{m}$ & $\mathrm{m}$ \\
\hline China & $\mathrm{m}$ & $\mathrm{m}$ & $\mathrm{m}$ & $\mathrm{m}$ & $\mathrm{m}$ & $\mathrm{m}$ & $\mathrm{m}$ & $\mathrm{m}$ & $\mathrm{m}$ & $\mathrm{m}$ \\
\hline Estonia $^{2}$ & 0.61 & 0.61 & 0.61 & 0.70 & 0.70 & 0.70 & 20 & 20 & 22 & 1.09 \\
\hline India & $\mathrm{m}$ & $\mathrm{m}$ & $\mathrm{m}$ & $\mathrm{m}$ & $\mathrm{m}$ & $\mathrm{m}$ & $\mathrm{m}$ & $\mathrm{m}$ & $\mathrm{m}$ & $\mathrm{m}$ \\
\hline Indonesia & 0.51 & 0.59 & 0.65 & $\mathrm{~m}$ & $\mathrm{~m}$ & $\mathrm{~m}$ & $\mathrm{~m}$ & $\mathrm{~m}$ & $\mathrm{~m}$ & $\mathrm{~m}$ \\
\hline Israel $^{2}$ & 0.73 & 0.82 & 0.82 & 0.49 & 0.56 & 0.56 & 26 & 37 & 41 & 1.57 \\
\hline Russian Federation & $\mathrm{m}$ & $\mathrm{m}$ & $\mathrm{m}$ & $\mathrm{m}$ & $\mathrm{m}$ & $\mathrm{m}$ & $\mathrm{m}$ & $\mathrm{m}$ & $\mathrm{m}$ & $\mathrm{m}$ \\
\hline Slovenia ${ }^{1}$ & 1.18 & 1.18 & 1.18 & 0.55 & 0.55 & 0.55 & 47 & 47 & 51 & 1.09 \\
\hline
\end{tabular}

1. Year of reference 2006 for Columns 17, 18 and 19.

2. Year of reference 2008 for Columns 17, 18 and 19.

3. Year of reference 2007 for Columns 17, 18 and 19.

Source: Education at a Glance 2010: OECD Indicators, OECD Publishing. China, India and Indonesia: UNESCO Institute for Statistics (World Education Indicators Programme). See Annex 3 for notes (www.oecd.org/edu/eag2010).

StatLink 제그 http://dx.doi.org/10.1787/888932310510 


\section{Table A.4}

Organization of teachers' working time (2008)

Number of teaching weeks, teaching days, net teaching hours, and teacher working time over the school year, in public institutions

\begin{tabular}{|c|c|c|c|c|c|c|c|c|c|c|c|c|c|c|c|}
\hline & \multicolumn{3}{|c|}{$\begin{array}{c}\text { Number of weeks } \\
\text { of instruction }\end{array}$} & \multicolumn{3}{|c|}{$\begin{array}{l}\text { Number of days } \\
\text { of instruction }\end{array}$} & \multicolumn{3}{|c|}{$\begin{array}{l}\text { Net teaching time } \\
\text { in hours }\end{array}$} & \multicolumn{3}{|c|}{$\begin{array}{l}\text { Working time required } \\
\text { at school in hours }\end{array}$} & \multicolumn{3}{|c|}{$\begin{array}{c}\text { Total statutory } \\
\text { working time in hours }\end{array}$} \\
\hline & 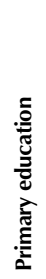 & 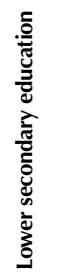 & 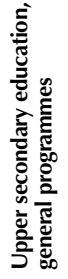 & 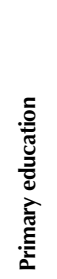 & 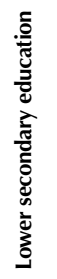 & 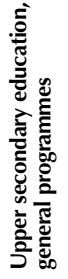 & 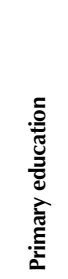 & 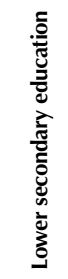 & 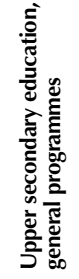 & 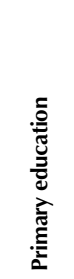 & 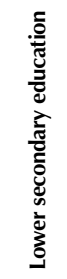 & 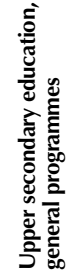 & 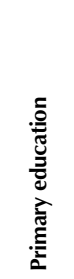 & 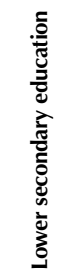 & 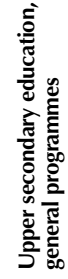 \\
\hline & (1) & (2) & (3) & (4) & (5) & (6) & (7) & (8) & (9) & (10) & (11) & (12) & (13) & (14) & (15) \\
\hline Australia & 40 & 40 & 40 & 196 & 196 & 196 & 873 & 812 & 810 & 1207 & 1228 & 1228 & $a$ & $a$ & $a$ \\
\hline Austria & 38 & 38 & 38 & 180 & 180 & 180 & 779 & 607 & 589 & $\mathrm{a}$ & a & $\mathrm{a}$ & 1776 & 1776 & a \\
\hline Belgium (FI.) & 37 & 37 & 37 & 180 & 181 & 181 & 810 & 695 & 649 & 936 & a & a & a & a & a \\
\hline Belgium (Fr.) & 37 & 37 & 37 & 181 & 181 & 181 & 724 & 662 & 603 & a & a & a & a & a & a \\
\hline Chile & $\mathrm{m}$ & $\mathrm{m}$ & $\mathrm{m}$ & $\mathrm{m}$ & $\mathrm{m}$ & $\mathrm{m}$ & $\mathrm{m}$ & $\mathrm{m}$ & $\mathrm{m}$ & $\mathrm{m}$ & $\mathrm{m}$ & $\mathrm{m}$ & $\mathrm{m}$ & $\mathrm{m}$ & $\mathrm{m}$ \\
\hline Czech Republic & 40 & 40 & 40 & 193 & 193 & 193 & 849 & 637 & 608 & a & a & a & 1688 & 1688 & 1688 \\
\hline Denmark & 42 & 42 & 42 & 200 & 200 & 200 & 648 & 648 & 364 & 1306 & 1306 & $\mathrm{~m}$ & 1680 & 1680 & 1680 \\
\hline England & 38 & 38 & 38 & 190 & 190 & 190 & 654 & 722 & 722 & 1265 & 1265 & 1265 & 1265 & 1265 & 1265 \\
\hline Finland & 38 & 38 & 38 & 188 & 188 & 188 & 677 & 592 & 550 & $\mathrm{a}$ & $\mathrm{a}$ & a & $\mathrm{a}$ & a & a \\
\hline France & 36 & 36 & 36 & $\mathrm{~m}$ & $\mathrm{~m}$ & $\mathrm{~m}$ & 926 & 644 & 630 & a & a & a & a & a & $\mathrm{a}$ \\
\hline Germany & 40 & 40 & 40 & 193 & 193 & 193 & 805 & 756 & 715 & a & a & $\mathrm{a}$ & 1775 & 1775 & 1775 \\
\hline Greece & 36 & 32 & 32 & 178 & 158 & 158 & 593 & 429 & 429 & 1140 & 1170 & 1170 & $a$ & $\mathrm{a}$ & a \\
\hline Hungary & 37 & 37 & 37 & 185 & 185 & 185 & 611 & 611 & 611 & a & $\mathrm{a}$ & $\mathrm{a}$ & 1864 & 1864 & 1864 \\
\hline Iceland & 36 & 36 & 35 & 180 & 180 & 175 & 671 & 671 & 560 & 1650 & 1650 & 1720 & 1800 & 1800 & 1800 \\
\hline Ireland & 37 & 33 & 33 & 183 & 167 & 167 & 915 & 735 & 735 & 1036 & 735 & 735 & a & a & a \\
\hline Italy & 38 & 38 & 38 & 167 & 167 & 167 & 735 & 601 & 601 & a & a & $\mathrm{a}$ & a & a & $\mathrm{a}$ \\
\hline Japan & 40 & 40 & 40 & 201 & 201 & 198 & 709 & 603 & 500 & a & a & a & 1899 & 1899 & 1899 \\
\hline Korea & 40 & 40 & 40 & 220 & 220 & 220 & 840 & 616 & 604 & $\mathrm{a}$ & a & a & 1680 & 1680 & 1680 \\
\hline Luxembourg & 36 & 36 & 36 & 176 & 176 & 176 & 739 & 634 & 634 & 900 & 828 & 828 & a & $\mathrm{a}$ & a \\
\hline Mexico & 41 & 41 & 36 & 200 & 200 & 173 & 800 & 1047 & 848 & 800 & 1167 & 971 & a & a & a \\
\hline Netherlands & 40 & $\mathrm{~m}$ & $\mathrm{~m}$ & 195 & $\mathrm{~m}$ & $\mathrm{~m}$ & 930 & 750 & 750 & a & a & a & 1659 & 1659 & 1659 \\
\hline New Zealand & 39 & 39 & 38 & 197 & 194 & 190 & 985 & 968 & 950 & 985 & 968 & 950 & $\mathrm{a}$ & a & a \\
\hline Norway & 38 & 38 & 38 & 190 & 190 & 190 & 741 & 654 & 523 & 1300 & 1225 & 1150 & 1688 & 1688 & 1688 \\
\hline Poland & 38 & 38 & 38 & 185 & 185 & 185 & 513 & 513 & 513 & a & $\mathrm{a}$ & a & 1520 & 1520 & 1520 \\
\hline Portugal & 37 & 37 & 37 & 171 & 171 & 171 & 855 & 752 & 752 & 1261 & 1261 & 1261 & 1432 & 1432 & 1432 \\
\hline Scotland & 38 & 38 & 38 & 190 & 190 & 190 & 855 & 855 & 855 & a & $\mathrm{a}$ & a & 1365 & 1365 & 1365 \\
\hline Slovak Republic & $\mathrm{m}$ & $\mathrm{m}$ & $\mathrm{m}$ & $\mathrm{m}$ & $\mathrm{m}$ & $\mathrm{m}$ & $\mathrm{m}$ & $\mathrm{m}$ & $\mathrm{m}$ & $\mathrm{m}$ & $\mathrm{m}$ & $\mathrm{m}$ & $\mathrm{m}$ & $\mathrm{m}$ & $\mathrm{m}$ \\
\hline Spain & 37 & 37 & 36 & 176 & 176 & 171 & 880 & 713 & 693 & 1140 & 1140 & 1140 & 1425 & 1425 & 1425 \\
\hline Sweden & $\mathrm{a}$ & $\mathrm{a}$ & $\mathrm{a}$ & a & $\mathrm{a}$ & $\mathrm{a}$ & $\mathrm{a}$ & a & $\mathrm{a}$ & 1360 & 1360 & 1360 & 1767 & 1767 & 1767 \\
\hline Switzerland & $\mathrm{m}$ & $\mathrm{m}$ & $\mathrm{m}$ & $\mathrm{m}$ & $\mathrm{m}$ & $\mathrm{m}$ & $\mathrm{m}$ & $\mathrm{m}$ & $\mathrm{m}$ & $\mathrm{m}$ & $\mathrm{m}$ & $\mathrm{m}$ & $\mathrm{m}$ & $\mathrm{m}$ & $\mathrm{m}$ \\
\hline Turkey & $\mathrm{m}$ & $\mathrm{a}$ & $\mathrm{m}$ & $\mathrm{m}$ & $\mathrm{a}$ & $\mathrm{m}$ & $\mathrm{m}$ & a & $\mathrm{m}$ & $\mathrm{m}$ & a & $\mathrm{m}$ & $\mathrm{m}$ & a & $\mathrm{m}$ \\
\hline United States & 36 & 36 & 36 & 180 & 180 & 180 & 1097 & 1068 & 1051 & 1381 & 1381 & 1378 & 1913 & 1977 & 1998 \\
\hline OECD average & 38 & 38 & 37 & 187 & 186 & 184 & 786 & 703 & 661 & 1178 & 1192 & 1166 & 1659 & 1662 & 1657 \\
\hline EU19 average & 38 & 37 & 37 & 184 & 181 & 181 & 763 & 661 & 632 & 1149 & 1133 & 1108 & 1601 & 1601 & 1585 \\
\hline
\end{tabular}

\begin{tabular}{|c|c|c|c|c|c|c|c|c|c|c|c|c|c|c|c|}
\hline Brazil & $\mathrm{m}$ & $\mathrm{m}$ & $\mathrm{m}$ & $\mathrm{m}$ & $\mathrm{m}$ & $\mathrm{m}$ & $\mathrm{m}$ & $\mathrm{m}$ & $\mathrm{m}$ & $\mathrm{m}$ & $\mathrm{m}$ & $\mathrm{m}$ & $\mathrm{m}$ & $\mathrm{m}$ & $\mathrm{m}$ \\
\hline China & 35 & 35 & 35 & 175 & 175 & 175 & $\mathrm{~m}$ & $\mathrm{~m}$ & $\mathrm{~m}$ & $\mathrm{~m}$ & $\mathrm{~m}$ & $\mathrm{~m}$ & $\mathrm{~m}$ & $\mathrm{~m}$ & $\mathrm{~m}$ \\
\hline Estonia & 39 & 39 & 39 & 175 & 175 & 175 & 630 & 630 & 578 & 1540 & 1540 & 1540 & a & a & $\mathrm{a}$ \\
\hline India & $\mathrm{m}$ & $\mathrm{m}$ & $\mathrm{m}$ & $\mathrm{m}$ & $\mathrm{m}$ & $\mathrm{m}$ & $\mathrm{m}$ & $\mathrm{m}$ & $\mathrm{m}$ & $\mathrm{m}$ & $\mathrm{m}$ & $\mathrm{m}$ & $\mathrm{m}$ & $\mathrm{m}$ & $\mathrm{m}$ \\
\hline Indonesia & 44 & 44 & 44 & 252 & 164 & 164 & 1260 & 738 & 738 & $\mathrm{~m}$ & $\mathrm{~m}$ & $\mathrm{~m}$ & $\mathrm{~m}$ & $\mathrm{~m}$ & $\mathrm{~m}$ \\
\hline Israel & 43 & 42 & 42 & 185 & 178 & 178 & 755 & 598 & 541 & 981 & 783 & 712 & a & a & a \\
\hline Russian Federation & 34 & 35 & 35 & 164 & 169 & 169 & 738 & 761 & 761 & a & $\mathrm{a}$ & a & $\mathrm{a}$ & a & a \\
\hline Slovenia & 40 & 40 & 40 & 188 & 188 & 188 & 682 & 682 & 626 & a & a & a & a & a & $\mathrm{a}$ \\
\hline
\end{tabular}

Source: Education at a Glance 2010: OECD Indicators, OECD Publishing. India, Indonesia: UNESCO Institute for Statistics (World Education Indicators Programme). China: The Ministry of Education, Notes on the Experimental Curriculum of Compulsory Education, 19 November 2001. See Annex 3 for notes (www.oecd.org/edu/eag2010). StatLink הत्माज http://dx.doi.org/10.1787/888932310529 


\section{Table A.5}

Number of teaching hours per year $(1996,2008)$

Net contact time in hours per year in public institutions by level of education, and index of change from 1996 to 2008

\begin{tabular}{|c|c|c|c|c|c|c|c|c|c|}
\hline & \multicolumn{3}{|c|}{ Primary education } & \multicolumn{3}{|c|}{ Lower secondary education } & \multicolumn{3}{|c|}{$\begin{array}{l}\text { Upper secondary education, } \\
\text { general programmes }\end{array}$} \\
\hline & 2008 & 1996 & $\begin{array}{c}\text { Index } \\
\text { of change } \\
1996-2008 \\
(1996=100)\end{array}$ & 2008 & 1996 & $\begin{array}{c}\text { Index } \\
\text { of change } \\
1996-2008 \\
(1996=100)\end{array}$ & 2008 & 1996 & $\begin{array}{c}\text { Index } \\
\text { of change } \\
1996-2008 \\
(1996=100)\end{array}$ \\
\hline & (1) & (2) & (3) & (4) & (5) & (6) & (7) & (8) & (9) \\
\hline Australia & 873 & $\mathrm{~m}$ & $\mathrm{~m}$ & 812 & $\mathrm{~m}$ & $\mathrm{~m}$ & 810 & $\mathrm{~m}$ & $\mathrm{~m}$ \\
\hline Austria & 779 & 684 & 114 & 607 & 658 & 92 & 589 & 623 & 95 \\
\hline Belgium (Fl.) & 810 & 841 & 96 & 695 & 724 & 96 & 649 & 679 & 96 \\
\hline Belgium (Fr.) & 724 & 858 & 84 & 662 & 734 & 90 & 603 & 677 & 89 \\
\hline Chile & $\mathrm{m}$ & $\mathrm{m}$ & $\mathrm{m}$ & $\mathrm{m}$ & $\mathrm{m}$ & $\mathrm{m}$ & $\mathrm{m}$ & $\mathrm{m}$ & $\mathrm{m}$ \\
\hline Czech Republic & 849 & w & $\mathrm{m}$ & 637 & 607 & 105 & 608 & 580 & 105 \\
\hline Denmark & 648 & 640 & 101 & 648 & 640 & 101 & 364 & 560 & 65 \\
\hline England & 654 & w & $\mathrm{m}$ & 722 & w & $\mathrm{m}$ & 722 & $\mathrm{~m}$ & $\mathrm{~m}$ \\
\hline Finland & 677 & $\mathrm{~m}$ & $\mathrm{~m}$ & 592 & $\mathrm{~m}$ & $\mathrm{~m}$ & 550 & $\mathrm{~m}$ & $\mathrm{~m}$ \\
\hline France & 926 & 900 & 103 & 644 & 647 & 100 & 630 & 636 & 99 \\
\hline Germany & 805 & 772 & 104 & 756 & 715 & 106 & 715 & 671 & 106 \\
\hline Greece & 593 & 780 & 76 & 429 & 629 & 68 & 429 & 629 & 68 \\
\hline Hungary & 611 & w & $\mathrm{m}$ & 611 & 473 & 129 & 611 & 473 & 129 \\
\hline Iceland & 671 & $\mathrm{~m}$ & $\mathrm{~m}$ & 671 & $\mathrm{~m}$ & $\mathrm{~m}$ & 560 & $\mathrm{~m}$ & $\mathrm{~m}$ \\
\hline Ireland & 915 & 915 & 100 & 735 & 735 & 100 & 735 & 735 & 100 \\
\hline Italy & 735 & 735 & 100 & 601 & 601 & 100 & 601 & 601 & 100 \\
\hline Japan & 709 & $\mathrm{~m}$ & $\mathrm{~m}$ & 603 & $\mathrm{~m}$ & $\mathrm{~m}$ & 500 & $\mathrm{~m}$ & $\mathrm{~m}$ \\
\hline Korea & 840 & $\mathrm{~m}$ & $\mathrm{~m}$ & 616 & w & $\mathrm{m}$ & 604 & w & $\mathrm{m}$ \\
\hline Luxembourg & 739 & $\mathrm{~m}$ & $\mathrm{~m}$ & 634 & $\mathrm{~m}$ & $\mathrm{~m}$ & 634 & $\mathrm{~m}$ & $\mathrm{~m}$ \\
\hline Mexico & 800 & 800 & 100 & 1047 & 1182 & 89 & 848 & $\mathrm{~m}$ & $\mathrm{~m}$ \\
\hline Netherlands & 930 & 930 & 100 & 750 & 867 & 87 & 750 & 867 & 87 \\
\hline New Zealand & 985 & 985 & 100 & 968 & 968 & 100 & 950 & 950 & 100 \\
\hline Norway & 741 & 713 & 104 & 654 & 633 & 103 & 523 & 505 & 104 \\
\hline Poland & 513 & $\mathrm{~m}$ & $\mathrm{~m}$ & 513 & $\mathrm{~m}$ & $\mathrm{~m}$ & 513 & $\mathrm{~m}$ & $\mathrm{~m}$ \\
\hline Portugal & 855 & 783 & 109 & 752 & 644 & 117 & 752 & 574 & 131 \\
\hline Scotland & 855 & 975 & 88 & 855 & $\mathrm{~m}$ & $\mathrm{~m}$ & 855 & 917 & 93 \\
\hline Slovak Republic & $\mathrm{m}$ & $\mathrm{m}$ & $\mathrm{m}$ & $\mathrm{m}$ & $\mathrm{m}$ & $\mathrm{m}$ & $\mathrm{m}$ & $\mathrm{m}$ & $\mathrm{m}$ \\
\hline Spain & 880 & 900 & 98 & 713 & $\mathrm{a}$ & $\mathrm{m}$ & 693 & 630 & 110 \\
\hline Sweden & $\mathrm{a}$ & 624 & $\mathrm{~m}$ & a & 576 & $\mathrm{~m}$ & a & 528 & $\mathrm{~m}$ \\
\hline Switzerland & $\mathrm{m}$ & 871 & $\mathrm{~m}$ & $\mathrm{~m}$ & 850 & $\mathrm{~m}$ & $\mathrm{~m}$ & 669 & $\mathrm{~m}$ \\
\hline Turkey & $\mathrm{m}$ & $\mathrm{m}$ & $\mathrm{m}$ & $\mathrm{a}$ & a & $\mathrm{a}$ & $\mathrm{m}$ & $\mathrm{m}$ & $\mathrm{m}$ \\
\hline United States & 1097 & w & $\mathrm{m}$ & 1068 & w & $\mathrm{m}$ & 1051 & w & $\mathrm{m}$ \\
\hline OECD average & 786 & 817 & & 703 & 716 & & 661 & 658 & \\
\hline EU19 average & 763 & 810 & & 661 & 661 & & 632 & 649 & \\
\hline
\end{tabular}

\begin{tabular}{|c|c|c|c|c|c|c|c|c|c|c|}
\hline & Brazil & $\mathrm{m}$ & $\mathrm{m}$ & $\mathrm{m}$ & 800 & $\mathrm{~m}$ & $\mathrm{~m}$ & 800 & $\mathrm{~m}$ & $\mathrm{~m}$ \\
\hline & Estonia & 630 & $\mathrm{~m}$ & $\mathrm{~m}$ & 630 & $\mathrm{~m}$ & $\mathrm{~m}$ & 578 & $\mathrm{~m}$ & $\mathrm{~m}$ \\
\hline & Israel & 755 & $\mathrm{~m}$ & $\mathrm{~m}$ & 598 & $\mathrm{~m}$ & $\mathrm{~m}$ & 541 & $\mathrm{~m}$ & $\mathrm{~m}$ \\
\hline & Russian Federation & 738 & $\mathrm{~m}$ & $\mathrm{~m}$ & 761 & $\mathrm{~m}$ & $\mathrm{~m}$ & 761 & $\mathrm{~m}$ & $\mathrm{~m}$ \\
\hline & Slovenia & 682 & $\mathrm{~m}$ & $\mathrm{~m}$ & 682 & $\mathrm{~m}$ & $\mathrm{~m}$ & 626 & $\mathrm{~m}$ & $\mathrm{~m}$ \\
\hline
\end{tabular}

Source: Education at a Glance 2010: OECD Indicators, OECD Publishing. See Annex 3 for notes (www.oecd.org/edu/eag2010). StatLink 젬ㄴ http://dx.doi.org/10.1787/888932310529 


\section{Table A.6}

Participation of teachers in professional development in the previous 18 months (2007-08)

Participation rates, average number of days and average of compulsory days of professional development undertaken by teachers of lower secondary education in the 18 months prior to the survey

\begin{tabular}{|c|c|c|c|c|c|c|c|c|}
\hline & \multicolumn{2}{|c|}{$\begin{array}{l}\text { Percentage of teachers } \\
\text { who undertook some } \\
\text { professional development } \\
\text { in the previous } 18 \text { months }\end{array}$} & \multicolumn{2}{|c|}{$\begin{array}{c}\text { Average days } \\
\text { of professional development } \\
\text { across all teachers }\end{array}$} & \multicolumn{2}{|c|}{$\begin{array}{c}\text { Average days } \\
\text { of professional development } \\
\text { among those who participated }\end{array}$} & \multicolumn{2}{|c|}{$\begin{array}{l}\text { Average percentage } \\
\text { of professional development day } \\
\text { taken that were compulsory }\end{array}$} \\
\hline & $\%$ & (S.E.) & Mean & (S.E.) & Mean & (S.E.) & $\%$ & (S.E.) \\
\hline Australia & 96.7 & $(0.43)$ & 8.7 & $(0.19)$ & 9.0 & $(0.20)$ & 47.3 & $(1.17)$ \\
\hline Austria & 96.6 & $(0.37)$ & 10.5 & $(0.17)$ & 10.9 & $(0.16)$ & 31.4 & $(0.66)$ \\
\hline Belgium (FI.) & 90.3 & $(0.73)$ & 8.0 & $(0.38)$ & 8.8 & $(0.42)$ & 33.6 & $(0.95)$ \\
\hline Brazil & 83.0 & (1.21) & 17.3 & $(0.70)$ & 20.8 & $(0.79)$ & 40.2 & (1.17) \\
\hline Bulgaria & 88.3 & (1.17) & 27.2 & (1.65) & 30.8 & (2.04) & 46.9 & (2.11) \\
\hline Denmark & 75.6 & (1.26) & 9.8 & $(0.34)$ & 12.9 & $(0.40)$ & 34.6 & (1.43) \\
\hline Estonia & 92.7 & $(0.50)$ & 13.1 & $(0.29)$ & 14.2 & $(0.31)$ & 49.2 & (1.20) \\
\hline Hungary & 86.9 & (1.77) & 14.5 & $(0.50)$ & 16.7 & $(0.41)$ & 46.1 & (1.58) \\
\hline Iceland & 77.1 & (1.10) & 10.7 & $(0.44)$ & 13.9 & $(0.56)$ & 49.9 & (1.30) \\
\hline Ireland & 89.7 & $(0.78)$ & 5.6 & $(0.21)$ & 6.2 & $(0.21)$ & 41.4 & $(0.99)$ \\
\hline Italy & 84.6 & $(0.76)$ & 26.6 & $(0.98)$ & 31.4 & (1.17) & 40.0 & (1.08) \\
\hline Korea & 91.9 & $(0.59)$ & 30.0 & $(0.57)$ & 32.7 & $(0.55)$ & 46.9 & $(0.85)$ \\
\hline Lithuania & 95.5 & $(0.40)$ & 11.2 & $(0.21)$ & 11.8 & $(0.21)$ & 56.6 & $(0.98)$ \\
\hline Malaysia & 91.7 & $(0.67)$ & 11.0 & $(0.32)$ & 11.9 & $(0.33)$ & 88.1 & $(0.64)$ \\
\hline Malta & 94.1 & $(0.75)$ & 7.3 & $(0.25)$ & 7.8 & $(0.26)$ & 78.4 & (1.07) \\
\hline Mexico & 91.5 & $(0.60)$ & 34.0 & (1.60) & 37.1 & (1.78) & 66.4 & $(1.22)$ \\
\hline Norway & 86.7 & $(0.87)$ & 9.2 & $(0.30)$ & 10.6 & $(0.34)$ & 55.5 & (1.25) \\
\hline Poland & 90.4 & $(0.67)$ & 26.1 & (1.10) & 28.9 & $(1.20)$ & 41.0 & (1.14) \\
\hline Portugal & 85.8 & $(0.87)$ & 18.5 & $(0.89)$ & 21.6 & (1.01) & 35.1 & $(0.99)$ \\
\hline Slovak Republic & 75.0 & (1.13) & 7.2 & $(0.30)$ & 9.6 & $(0.38)$ & 44.1 & (1.19) \\
\hline Slovenia & 96.9 & $(0.35)$ & 8.3 & $(0.20)$ & 8.6 & $(0.20)$ & 60.5 & $(0.93)$ \\
\hline Spain & 100.0 & $(0.03)$ & 25.6 & $(0.51)$ & 25.6 & $(0.51)$ & 66.8 & $(0.99)$ \\
\hline Turkey & 74.8 & $(2.09)$ & 11.2 & $(0.52)$ & 14.9 & $(0.65)$ & 72.8 & (1.65) \\
\hline TALIS average & 88.5 & $(0.20)$ & 15.3 & $(0.14)$ & 17.3 & $(0.16)$ & 51.0 & $(0.25)$ \\
\hline
\end{tabular}

Source: OECD (2009), Creating Effective Teaching and Learning Environments: First Results from TALIS.

StatLink ants http://dx.doi.org/10.1787/607807256201 


\section{Table A.7}

\section{Amount of professional development undertaken by teachers} in the previous 18 months (2007-08) - teacher characteristics

Average number of days of professional development undertaken by teachers of different characteristics [among those teachers of lower secondary education who took some professional development]

\begin{tabular}{|c|c|c|c|c|c|c|c|c|c|c|c|c|}
\hline & \multicolumn{2}{|c|}{ Female teachers } & \multicolumn{2}{|c|}{ Male teachers } & \multicolumn{2}{|c|}{$\begin{array}{c}\text { Teachers } \\
\text { aged under } 30 \text { years }\end{array}$} & \multicolumn{2}{|c|}{$\begin{array}{c}\text { Teachers } \\
\text { aged } 30-39 \text { years }\end{array}$} & \multicolumn{2}{|c|}{$\begin{array}{c}\text { Teachers } \\
\text { aged } 40-49 \text { years }\end{array}$} & \multicolumn{2}{|c|}{$\begin{array}{c}\text { Teachers } \\
\text { aged } 50+\text { years }\end{array}$} \\
\hline & Mean & (S.E.) & Mean & (S.E.) & Mean & (S.E.) & Mean & (S.E.) & Mean & (S.E.) & Mean & (S.E.) \\
\hline Australia & 9.0 & $(0.24)$ & 9.0 & $(0.28)$ & 9.0 & $(0.52)$ & 8.9 & $(0.41)$ & 9.1 & $(0.34)$ & 9.1 & $(0.31)$ \\
\hline Austria & 11.2 & $(0.20)$ & 10.3 & $(0.23)$ & 12.4 & $(0.72)$ & 10.5 & $(0.47)$ & 11.3 & $(0.25)$ & 10.5 & $(0.25)$ \\
\hline Belgium (Fl.) & 8.5 & $(0.55)$ & 9.5 & $(0.48)$ & 8.7 & $(0.62)$ & 8.8 & $(0.79)$ & 8.6 & $(0.61)$ & 9.2 & $(0.88)$ \\
\hline Brazil & 20.7 & $(0.88)$ & 21.2 & $(1.02)$ & 22.2 & $(1.51)$ & 22.3 & (1.15) & 19.7 & $(0.85)$ & 17.0 & $(1.40)$ \\
\hline Bulgaria & 30.7 & $(2.00)$ & 31.5 & (3.79) & 27.3 & (5.36) & 34.2 & $(4.29)$ & 33.6 & $(4.21)$ & 26.8 & $(1.67)$ \\
\hline Denmark & 13.4 & $(0.53)$ & 12.3 & $(0.68)$ & 17.3 & $(3.02)$ & 13.4 & $(0.70)$ & 15.8 & $(1.07)$ & 10.3 & $(0.50)$ \\
\hline Estonia & 14.6 & $(0.36)$ & 11.6 & $(0.51)$ & 15.3 & $(1.19)$ & 16.8 & $(0.80)$ & 15.2 & $(0.55)$ & 11.8 & $(0.36)$ \\
\hline Hungary & 16.6 & $(0.52)$ & 16.9 & $(1.28)$ & 15.4 & $(1.05)$ & 16.3 & $(0.95)$ & 18.3 & $(0.80)$ & 15.4 & $(1.29)$ \\
\hline Iceland & 14.4 & $(0.68)$ & 12.7 & $(0.83)$ & 11.5 & $(1.41)$ & 12.9 & $(0.84)$ & 15.2 & $(0.96)$ & 14.2 & $(0.99)$ \\
\hline Ireland & 6.0 & $(0.23)$ & 6.7 & $(0.45)$ & 5.8 & $(0.49)$ & 6.6 & $(0.49)$ & 6.8 & $(0.45)$ & 5.7 & $(0.30)$ \\
\hline Italy & 30.5 & $(1.12)$ & 34.8 & (2.52) & 64.1 & $(12.08)$ & 50.1 & (3.36) & 30.4 & (1.54) & 24.1 & $(1.04)$ \\
\hline Korea & 34.2 & $(0.69)$ & 30.0 & $(0.91)$ & 43.3 & $(1.61)$ & 36.7 & $(1.01)$ & 30.3 & $(0.82)$ & 24.3 & $(1.51)$ \\
\hline Lithuania & 12.1 & $(0.24)$ & 10.1 & $(0.46)$ & 11.2 & $(0.75)$ & 11.5 & $(0.41)$ & 12.5 & $(0.34)$ & 11.4 & $(0.31)$ \\
\hline Malaysia & 11.8 & $(0.39)$ & 12.3 & $(0.44)$ & 12.0 & $(0.56)$ & 11.7 & $(0.43)$ & 12.2 & $(0.37)$ & 11.9 & $(0.65)$ \\
\hline Malta & 7.9 & $(0.39)$ & 7.6 & $(0.32)$ & 7.7 & $(0.51)$ & 7.5 & $(0.42)$ & 8.6 & $(0.86)$ & 7.9 & $(0.50)$ \\
\hline Mexico & 39.9 & (2.17) & 33.9 & (2.72) & 48.5 & (5.64) & 41.8 & (3.88) & 34.5 & (2.27) & 28.1 & $(2.26)$ \\
\hline Norway & 10.9 & $(0.49)$ & 10.1 & $(0.47)$ & 10.2 & $(0.95)$ & 10.4 & $(0.58)$ & 12.6 & $(0.86)$ & 9.7 & $(0.55)$ \\
\hline Poland & 29.9 & $(1.40)$ & 25.6 & $(1.60)$ & 35.2 & $(3.22)$ & 33.2 & $(2.08)$ & 25.5 & $(1.45)$ & 17.9 & $(1.64)$ \\
\hline Portugal & 20.3 & $(1.06)$ & 24.8 & (1.95) & 38.5 & $(5.51)$ & 21.3 & $(1.29)$ & 20.2 & $(1.12)$ & 17.7 & $(2.21)$ \\
\hline Slovak Republic & 9.9 & $(0.43)$ & 8.3 & $(0.61)$ & 9.8 & $(1.05)$ & 9.7 & $(0.52)$ & 10.9 & $(0.53)$ & 8.5 & $(0.45)$ \\
\hline Slovenia & 8.7 & $(0.23)$ & 8.3 & $(0.34)$ & 9.4 & $(0.54)$ & 9.7 & $(0.49)$ & 8.4 & $(0.25)$ & 7.2 & $(0.26)$ \\
\hline Spain & 26.7 & $(0.64)$ & 24.2 & $(0.60)$ & 29.4 & $(1.51)$ & 25.7 & $(0.91)$ & 26.8 & $(0.73)$ & 23.0 & $(0.69)$ \\
\hline Turkey & 13.6 & $(0.82)$ & 16.2 & (1.29) & 16.9 & (1.13) & 13.6 & $(0.74)$ & 14.4 & (1.91) & 10.6 & (1.18) \\
\hline TALIS average & 17.5 & $(0.18)$ & 16.9 & $(0.29)$ & 20.9 & $(0.72)$ & 18.9 & $(0.34)$ & 17.4 & $(0.28)$ & 14.4 & $(0.23)$ \\
\hline
\end{tabular}

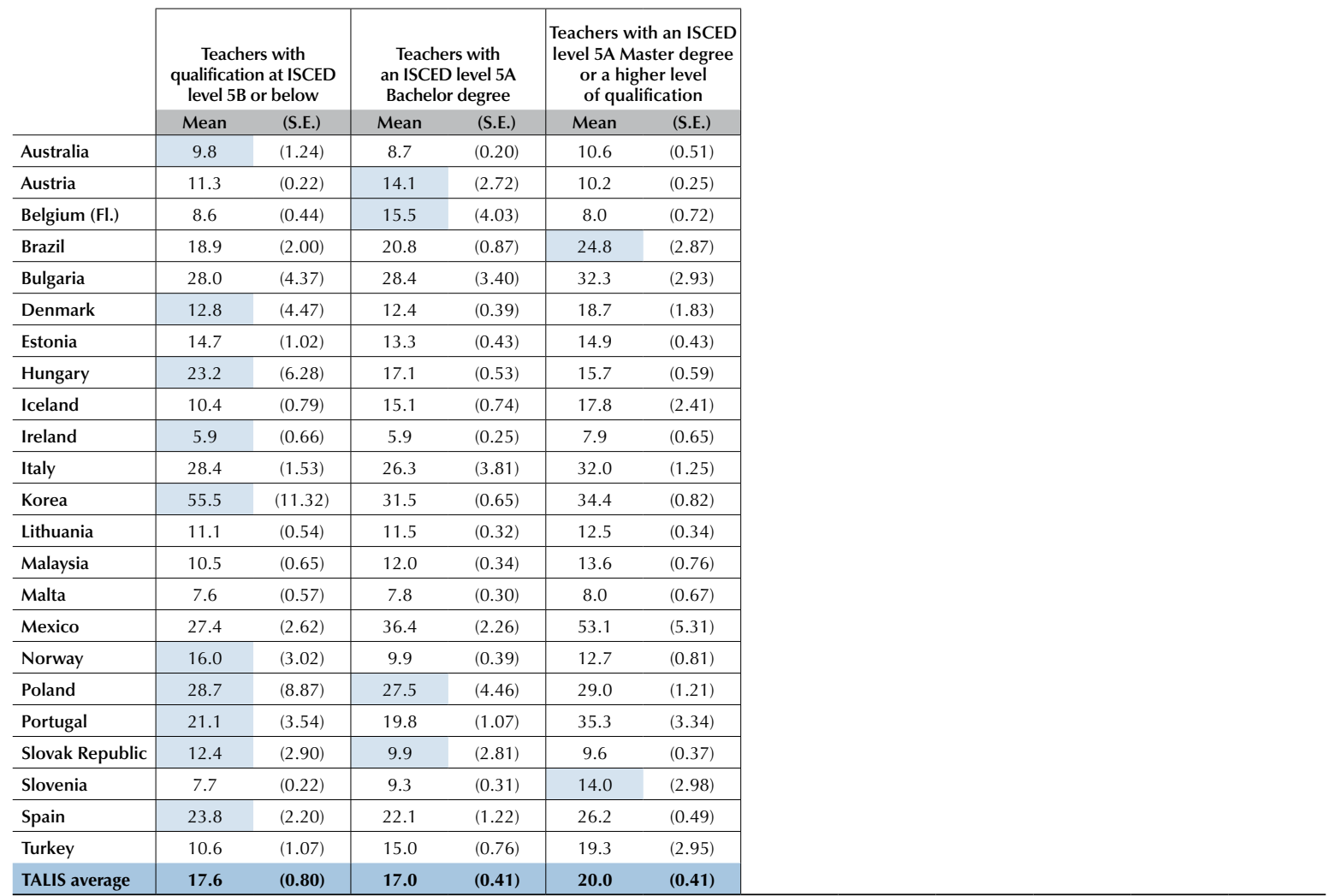




\section{Table A.8}

\section{Amount of professional development undertaken by teachers in the previous 18 months (2007-08) - school characteristics}

Average number of days of professional development undertaken by teachers in schools of different characteristics [among those teachers of lower secondary education who took some professional development]

\begin{tabular}{|c|c|c|c|c|c|c|c|c|c|c|c|c|c|c|}
\hline & \multicolumn{2}{|c|}{$\begin{array}{c}\text { Teachers } \\
\text { in public schools }\end{array}$} & \multicolumn{2}{|c|}{$\begin{array}{c}\text { Teachers } \\
\text { in private schools }\end{array}$} & \multicolumn{2}{|c|}{$\begin{array}{l}\text { Teachers } \\
\text { in schools } \\
\text { in a village }\end{array}$} & \multicolumn{2}{|c|}{$\begin{array}{c}\text { Teachers } \\
\text { in schools } \\
\text { in a small town }\end{array}$} & \multicolumn{2}{|c|}{$\begin{array}{l}\text { Teachers } \\
\text { in schools } \\
\text { in a town }\end{array}$} & \multicolumn{2}{|c|}{$\begin{array}{c}\text { Teachers } \\
\text { in schools in a city }\end{array}$} & \multicolumn{2}{|c|}{$\begin{array}{c}\text { Teachers } \\
\text { in schools } \\
\text { in a large city }\end{array}$} \\
\hline & Mean & (S.E.) & Mean & (S.E.) & Mean & (S.E.) & Mean & (S.E.) & Mean & (S.E.) & Mean & (S.E.) & Mean & (S.E.) \\
\hline Australia & 8.9 & $(0.24)$ & 9.2 & $(0.32)$ & 10.1 & $(0.57)$ & 9.4 & $(0.74)$ & 9.0 & $(0.35)$ & 8.8 & $(0.40)$ & 9.0 & $(0.32)$ \\
\hline Austria & 11.0 & $(0.19)$ & 10.2 & $(0.55)$ & 11.3 & $(0.44)$ & 10.2 & $(0.24)$ & 12.1 & (0.58) & 11.2 & $(0.45)$ & 11.3 & $(0.40)$ \\
\hline Belgium (FI.) & 12.2 & $(1.31)$ & 7.6 & $(0.34)$ & 15.6 & $(4.07)$ & 7.7 & $(0.46)$ & 9.1 & $(0.86)$ & 10.3 & $(0.88)$ & $\mathrm{a}$ & $a$ \\
\hline Brazil & 21.1 & $(0.91)$ & 19.0 & $(1.36)$ & 22.8 & $(3.01)$ & 19.5 & (1.18) & 20.2 & $(1.42)$ & 21.3 & $(1.23)$ & 20.2 & (1.19) \\
\hline Bulgaria & 30.9 & $(2.08)$ & 20.5 & $(9.36)$ & 27.5 & (3.54) & 32.9 & (6.88) & 32.1 & $(2.56)$ & 30.6 & (3.18) & 30.2 & (2.55) \\
\hline Denmark & 13.4 & $(0.49)$ & 12.4 & (0.99) & 11.7 & (0.98) & 14.0 & (1.45) & 12.1 & $(0.77)$ & 15.0 & (1.37) & 15.4 & (1.74) \\
\hline Estonia & 14.2 & $(0.31)$ & 14.9 & $(3.11)$ & 13.9 & $(0.45)$ & 14.1 & $(0.76)$ & 14.8 & $(0.85)$ & 14.3 & $(0.64)$ & $\mathrm{a}$ & $\mathrm{a}$ \\
\hline Hungary & 16.6 & $(0.50)$ & 17.0 & $(0.81)$ & 16.7 & $(1.17)$ & 17.6 & (1.06) & 16.2 & (1.04) & 17.0 & $(0.91)$ & 16.0 & $(0.81)$ \\
\hline Iceland & 14.3 & $(0.65)$ & 6.9 & $(2.27)$ & 13.3 & $(0.71)$ & 14.9 & $(1.21)$ & 15.4 & (1.37) & 13.3 & (1.09) & $\mathrm{a}$ & $a$ \\
\hline Ireland & 6.4 & $(0.33)$ & 5.7 & $(0.35)$ & 5.9 & $(0.45)$ & 5.9 & $(0.40)$ & 6.2 & $(0.57)$ & 6.7 & $(0.97)$ & 5.9 & $(0.51)$ \\
\hline Italy & 30.8 & $(1.20)$ & 44.5 & $(7.40)$ & 30.4 & $(2.91)$ & 33.0 & $(2.38)$ & 29.5 & $(1.48)$ & 29.2 & $(2.43)$ & 35.3 & (3.84) \\
\hline Korea & 34.3 & (0.76) & 25.1 & (1.29) & 32.9 & (2.74) & 33.0 & (2.12) & 32.2 & (1.58) & 32.2 & (1.43) & 33.1 & (0.94) \\
\hline Lithuania & 11.8 & $(0.22)$ & 11.4 & (1.58) & 10.9 & $(0.32)$ & 11.7 & $(0.54)$ & 12.3 & $(0.53)$ & 12.2 & $(0.38)$ & $\mathrm{a}$ & $\mathrm{a}$ \\
\hline Malaysia & 12.0 & $(0.33)$ & 10.0 & (1.45) & 12.1 & $(0.60)$ & 11.6 & $(0.47)$ & 12.3 & $(0.96)$ & 11.9 & $(1.04)$ & 13.4 & $(0.41)$ \\
\hline Malta & 7.5 & $(0.34)$ & 8.2 & $(0.36)$ & 8.6 & $(0.78)$ & 7.9 & $(0.33)$ & 7.6 & $(0.54)$ & $\mathrm{a}$ & $\mathrm{a}$ & $\mathrm{a}$ & $a$ \\
\hline Mexico & 35.3 & (1.57) & 44.0 & $(6.21)$ & 30.6 & (7.64) & 38.6 & (4.31) & 35.6 & (3.13) & 32.2 & $(2.47)$ & 38.4 & (2.43) \\
\hline Norway & 10.7 & $(0.36)$ & 7.1 & (1.14) & 11.8 & $(0.78)$ & 10.4 & $(0.64)$ & 10.6 & (0.59) & 8.7 & $(0.57)$ & $\mathrm{a}$ & $\mathrm{a}$ \\
\hline Poland & 29.0 & $(1.26)$ & 27.9 & (3.86) & 26.5 & $(1.32)$ & 31.7 & (3.33) & 28.1 & $(1.92)$ & 29.7 & $(3.70)$ & 45.1 & (7.16) \\
\hline Portugal & 21.9 & (1.22) & 17.9 & (1.49) & 23.8 & (2.18) & 20.2 & (2.00) & 22.9 & (1.74) & 19.9 & (3.23) & 18.0 & (3.57) \\
\hline Slovak Republic & 9.7 & $(0.39)$ & 10.0 & (1.19) & 10.6 & $(1.07)$ & 9.4 & $(0.66)$ & 8.9 & $(0.46)$ & 10.3 & (1.19) & $\mathrm{a}$ & $\mathrm{a}$ \\
\hline Slovenia & 8.6 & $(0.21)$ & $\mathrm{a}$ & $\mathrm{a}$ & 8.9 & $(0.42)$ & 8.4 & $(0.29)$ & 9.0 & $(0.63)$ & 8.6 & $(0.73)$ & $\mathrm{a}$ & $\mathrm{a}$ \\
\hline Spain & 27.1 & $(0.62)$ & 21.1 & $(0.79)$ & 25.4 & (1.50) & 27.0 & $(0.88)$ & 25.3 & $(0.86)$ & 25.5 & (1.28) & 24.6 & (1.18) \\
\hline Turkey & 15.0 & $(0.72)$ & 14.9 & (1.13) & 15.1 & $(2.42)$ & 17.4 & (3.05) & 14.9 & (1.48) & 14.4 & $(0.83)$ & 15.8 & (1.32) \\
\hline TALIS average & 17.5 & $(0.18)$ & 16.6 & $(0.66)$ & 17.2 & $(0.50)$ & 17.7 & $(0.46)$ & 17.2 & $(0.28)$ & 17.4 & $(0.34)$ & 22.1 & $(0.44)$ \\
\hline
\end{tabular}

Denotes categories that include less than $5 \%$ of teachers.

Source: OECD (2009), Creating Effective Teaching and Learning Environments: First Results from TALIS.

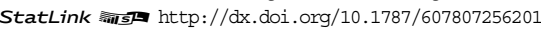

\section{Table A.9}

Types of professional development undertaken by teachers (2007-08)

Percentage of teachers of lower secondary education undertaking specified professional development activities in the previous 18 months

\begin{tabular}{|c|c|c|c|c|c|c|c|c|c|c|c|c|c|c|c|c|c|c|}
\hline & \multicolumn{2}{|c|}{$\begin{array}{c}\text { Courses and } \\
\text { workshops }\end{array}$} & \multicolumn{2}{|c|}{$\begin{array}{c}\text { Education } \\
\text { conferences } \\
\text { and seminars }\end{array}$} & \multicolumn{2}{|c|}{$\begin{array}{l}\text { Qualification } \\
\text { programmes }\end{array}$} & \multicolumn{2}{|c|}{$\begin{array}{l}\text { Observation } \\
\text { visits to other } \\
\text { schools }\end{array}$} & \multicolumn{2}{|c|}{$\begin{array}{l}\text { Professional } \\
\text { development } \\
\text { network }\end{array}$} & \multicolumn{2}{|c|}{$\begin{array}{l}\text { Individual and } \\
\text { collaborative } \\
\text { research }\end{array}$} & \multicolumn{2}{|c|}{$\begin{array}{c}\text { Mentoring } \\
\text { and peer } \\
\text { observation }\end{array}$} & \multicolumn{2}{|c|}{$\begin{array}{l}\text { Reading } \\
\text { professional } \\
\text { literature }\end{array}$} & \multicolumn{2}{|c|}{$\begin{array}{l}\text { Informal } \\
\text { dialogue } \\
\text { to improve } \\
\text { teaching }\end{array}$} \\
\hline & $\%$ & (S.E.) & $\%$ & (S.E.) & $\%$ & (S.E.) & $\%$ & (S.E.) & $\%$ & (S.E.) & $\%$ & (S.E.) & $\%$ & (S.E.) & $\%$ & (S.E.) & $\%$ & (S.E.) \\
\hline Australia & 90.6 & $(0.81)$ & 64.0 & (1.34) & 11.7 & $(0.80)$ & 22.2 & (1.42) & 60.1 & (1.38) & 36.6 & (1.21) & 48.6 & (1.30) & 82.4 & (1.09) & 93.7 & $(0.70)$ \\
\hline Austria & 91.9 & $(0.56)$ & 49.2 & (0.97) & 19.9 & (0.68) & 10.3 & $(0.55)$ & 37.6 & $(0.98)$ & 25.9 & $(0.82)$ & 18.4 & $(0.84)$ & 89.4 & $(0.57)$ & 91.9 & $(0.60)$ \\
\hline Belgium (FI.) & 85.2 & (0.89) & 32.6 & (1.33) & 17.8 & $(0.83)$ & 15.1 & (1.06) & 25.7 & (1.05) & 31.8 & $(0.87)$ & 22.1 & $(0.92)$ & 79.6 & $(0.98)$ & 91.3 & $(0.71)$ \\
\hline Brazil & 80.3 & (1.31) & 61.0 & (1.52) & 40.8 & (1.27) & 32.5 & (1.03) & 21.9 & (0.95) & 54.7 & (1.17) & 47.5 & (1.37) & 82.5 & $(0.78)$ & 94.2 & $(0.58)$ \\
\hline Bulgaria & 73.7 & (2.07) & 42.2 & (3.44) & 50.2 & (2.56) & 22.5 & (2.03) & 19.8 & $(2.22)$ & 24.5 & (1.73) & 35.4 & (3.01) & 93.5 & $(0.96)$ & 94.7 & $(0.70)$ \\
\hline Denmark & 81.2 & (1.33) & 41.6 & (1.56) & 15.4 & (1.47) & 10.4 & $(0.92)$ & 43.5 & (1.65) & 52.3 & (1.51) & 17.5 & (1.66) & 77.3 & (1.50) & 90.4 & $(0.89)$ \\
\hline Estonia & 92.5 & (0.66) & 50.6 & (1.29) & 27.7 & $(0.96)$ & 62.8 & (1.37) & 42.8 & (1.16) & 26.6 & (1.00) & 31.5 & (1.35) & 87.7 & $(0.85)$ & 93.8 & $(0.58)$ \\
\hline Hungary & 68.7 & (1.66) & 39.9 & (1.64) & 26.1 & (1.13) & 34.6 & (2.15) & 43.7 & (1.83) & 17.0 & $(0.84)$ & 46.7 & (1.93) & 88.4 & (1.11) & 79.1 & (1.39) \\
\hline Iceland & 72.1 & (1.30) & 52.1 & (1.25) & 18.8 & (1.02) & 60.0 & (1.27) & 82.6 & (1.11) & 18.2 & (1.08) & 33.4 & (1.16) & 82.8 & (1.05) & 94.9 & (0.65) \\
\hline Ireland & 85.7 & $(0.88)$ & 42.0 & (1.41) & 11.4 & $(0.67)$ & 7.6 & $(0.75)$ & 51.1 & (1.20) & 26.3 & (1.17) & 18.2 & $(1.12)$ & 60.3 & $(0.96)$ & 87.4 & $(0.81)$ \\
\hline Italy & 66.3 & (1.10) & 43.5 & (1.03) & 10.8 & $(0.50)$ & 16.0 & $(0.89)$ & 20.0 & $(0.75)$ & 56.5 & $(0.92)$ & 27.4 & (0.93) & 66.2 & $(0.81)$ & 93.1 & $(0.46)$ \\
\hline Korea & 85.0 & $(0.86)$ & 46.9 & $(1.24)$ & 27.5 & $(0.88)$ & 66.8 & (1.26) & 39.6 & (1.00) & 50.1 & (1.03) & 69.4 & (1.15) & 52.5 & (1.06) & 90.0 & $(0.63)$ \\
\hline Lithuania & 95.7 & $(0.43)$ & 67.6 & (1.10) & 43.9 & (1.16) & 57.1 & (1.21) & 37.6 & (1.05) & 48.1 & (1.00) & 39.7 & (1.16) & 93.5 & $(0.50)$ & 96.7 & $(0.38)$ \\
\hline Malaysia & 88.6 & $(0.71)$ & 32.4 & $(0.93)$ & 22.0 & (1.01) & 30.0 & (1.40) & 47.8 & (1.25) & 21.7 & (1.08) & 41.8 & $(1.26)$ & 61.5 & (1.63) & 95.7 & $(0.36)$ \\
\hline Malta & 90.2 & $(0.96)$ & 51.8 & (1.88) & 18.1 & (1.36) & 14.8 & (1.23) & 39.0 & (1.70) & 37.4 & (1.85) & 16.5 & (1.19) & 61.1 & (1.90) & 92.3 & (1.05) \\
\hline Mexico & 94.3 & $(0.57)$ & 33.1 & $(1.23)$ & 33.5 & (1.21) & 30.5 & (1.30) & 27.5 & (1.13) & 62.9 & (1.05) & 38.1 & (1.37) & 67.4 & (1.05) & 88.9 & $(0.86)$ \\
\hline Norway & 72.5 & $(1.40)$ & 40.4 & (1.61) & 17.6 & $(0.71)$ & 19.1 & (1.49) & 35.3 & (1.55) & 12.3 & $(0.72)$ & 22.0 & $(1.50)$ & 64.1 & $(1.12)$ & 94.0 & $(0.57)$ \\
\hline Poland & 90.8 & $(0.77)$ & 64.3 & (1.18) & 35.0 & $(0.95)$ & 19.7 & $(0.84)$ & 60.7 & (1.43) & 40.0 & (1.08) & 66.7 & (1.40) & 95.2 & $(0.46)$ & 95.8 & $(0.36)$ \\
\hline Portugal & 77.0 & $(0.91)$ & 51.6 & $(1.31)$ & 29.5 & $(0.87)$ & 26.4 & (1.03) & 15.0 & $(0.82)$ & 47.1 & (1.15) & 14.6 & $(0.84)$ & 73.3 & $(0.97)$ & 94.2 & $(0.49)$ \\
\hline Slovak Republic & 50.1 & (1.45) & 38.2 & (1.38) & 38.1 & (1.28) & 33.1 & (1.41) & 34.6 & (1.46) & 11.8 & $(0.83)$ & 64.8 & $(1.27)$ & 93.2 & $(0.64)$ & 95.9 & $(0.48)$ \\
\hline Slovenia & 88.1 & $(0.70)$ & 74.7 & (1.05) & 10.2 & $(0.65)$ & 7.7 & $(0.58)$ & 71.9 & (1.38) & 22.5 & $(0.97)$ & 29.1 & $(0.87)$ & 86.4 & $(0.73)$ & 97.0 & $(0.35)$ \\
\hline Spain & 83.9 & $(0.86)$ & 36.2 & (1.10) & 17.2 & $(0.62)$ & 14.7 & $(0.75)$ & 22.6 & $(0.84)$ & 49.2 & $(0.96)$ & 21.4 & (1.00) & 68.1 & $(0.93)$ & 92.6 & $(0.49)$ \\
\hline Turkey & 62.3 & (1.51) & 67.8 & (1.99) & 19.2 & (1.09) & 21.1 & (1.66) & 39.4 & (1.67) & 40.1 & (1.35) & 32.2 & (2.15) & 80.6 & (2.14) & 92.8 & $(0.82)$ \\
\hline TALIS average & 81.2 & (0.23) & 48.9 & $(0.32)$ & 24.5 & $(0.23)$ & 27.6 & $(0.26)$ & 40.0 & $(0.28)$ & 35.4 & $(0.24)$ & 34.9 & $(0.30)$ & 77.7 & $(0.23)$ & 92.6 & (0.14) \\
\hline
\end{tabular}

Source: OECD (2009), Creating Effective Teaching and Learning Environments: First Results from TALIS.

StatLink ails $\mathrm{http}: / / \mathrm{dx}$.doi.org/10.1787/607807256201 


\section{Table A.10}

\section{Teachers who wanted to participate in more development than they did} in the previous 18 months (2007-08)

Percentage of teachers of lower secondary education who wanted to take more professional development than they did in the previous 18 months, by certain teacher and school characteristics

\begin{tabular}{|c|c|c|c|c|c|c|c|c|c|c|c|c|c|c|c|c|c|c|c|c|}
\hline & \multicolumn{2}{|c|}{ All teachers } & \multicolumn{2}{|c|}{$\begin{array}{c}\text { Female } \\
\text { teachers }\end{array}$} & \multicolumn{2}{|c|}{$\begin{array}{c}\text { Male } \\
\text { teachers }\end{array}$} & \multicolumn{2}{|c|}{$\begin{array}{c}\text { Teachers } \\
\text { aged under } 40 \\
\text { years }\end{array}$} & \multicolumn{2}{|c|}{$\begin{array}{l}\text { Teachers } \\
\text { aged } 40+ \\
\text { years }\end{array}$} & \multicolumn{2}{|c|}{$\begin{array}{c}\text { Teachers with } \\
\text { qualification } \\
\text { below ISCED } \\
\text { level 5A }\end{array}$} & \multicolumn{2}{|c|}{$\begin{array}{c}\text { Teachers with } \\
\text { qualification at } \\
\text { ISCED level 5A } \\
\text { Bachelor } \\
\text { degree }\end{array}$} & \multicolumn{2}{|c|}{$\begin{array}{l}\text { Teachers with } \\
\text { qualification } \\
\text { at ISCED level } \\
\text { 5A Masters } \\
\text { degree or } \\
\text { higher }\end{array}$} & \multicolumn{2}{|c|}{$\begin{array}{c}\text { Teachers in } \\
\text { public schools }\end{array}$} & \multicolumn{2}{|c|}{$\begin{array}{c}\text { Teachers in } \\
\text { private schools }\end{array}$} \\
\hline & & (S.E.) & $\%$ & (S.E.) & $\%$ & (S.E.) & $\%$ & (S.E.) & $\%$ & (S.E.) & & (S.E.) & $\%$ & (S.E.) & $\%$ & (S.E.) & $\%$ & (S.E.) & $\%$ & (S.E.) \\
\hline Australia & 55.2 & (1.37) & 57.9 & (1.67) & 51.3 & (1.89) & 59.0 & (1.70) & 52.5 & $(1.70)$ & 24.6 & (11.05) & 55.0 & $(1.37)$ & 58.9 & $(2.83)$ & 55.5 & (1.49) & 54.8 & (2.49) \\
\hline Austria & 44.7 & $(0.93)$ & 46.0 & $(1.17)$ & 41.9 & (1.36) & 48.8 & (1.83) & 43.5 & $(1.00)$ & 40.3 & (1.18) & 41.8 & (8.01) & 51.9 & $(1.43)$ & 43.9 & $(1.01)$ & 53.4 & $(2.05)$ \\
\hline Belgium & 30.5 & (0.98) & 32.3 & (1.40) & 26.5 & (2.50) & 34.9 & $(1.22)$ & 25.6 & $(1.34)$ & 30.4 & $(1.02)$ & 23.0 & (3.04) & 36.0 & $(3.42)$ & 32.7 & $(1.17)$ & 29.7 & $(1.36)$ \\
\hline Brazil & 84.4 & $(0.77)$ & 85.9 & $(0.88)$ & 80.5 & (1.30) & 85.8 & (1.05) & 82.6 & $(1.21)$ & 86.4 & (2.41) & 83.9 & $(0.85)$ & 83.3 & (3.56) & 84.8 & $(0.89)$ & 83.6 & (1.52) \\
\hline Bulgaria & 68.9 & $(1.77)$ & 69.5 & $(1.62)$ & 65.8 & (4.77) & 70.9 & (2.83) & 68.0 & $(1.87)$ & 67.6 & (4.25) & 71.6 & (3.98) & 68.5 & (2.33) & 68.9 & $(1.78)$ & 64.5 & $(12.29)$ \\
\hline Denmark & 47.6 & (1.39) & 49.6 & (1.93) & 44.8 & (2.50) & 47.3 & (2.41) & 47.8 & (1.90) & 18.0 & (6.30) & 47.8 & (1.37) & 52.9 & (5.58) & 48.0 & (1.80) & 45.8 & (3.01) \\
\hline Estonia & 48.7 & $(1.07)$ & 48.6 & (1.16) & 49.2 & (2.38) & 48.3 & $(1.90)$ & 48.8 & $(1.26)$ & 48.7 & (2.89) & 49.8 & (1.74) & 47.8 & (1.49) & 48.6 & $(1.10)$ & 50.4 & (9.40) \\
\hline Hungary & 40.2 & $(2.00)$ & 39.9 & $(2.45)$ & 41.0 & (2.10) & 41.1 & (3.19) & 39.6 & $(1.81)$ & 39.3 & $(18.39$ & 38.6 & $(2.07)$ & 44.6 & $(2.22)$ & 40.1 & $(1.63)$ & 40.3 & $(5.22)$ \\
\hline Iceland & 37.9 & (1.47) & 40.6 & (1.93) & 32.0 & (2.36) & 36.3 & $(2.23)$ & 39.0 & (1.84) & 36.5 & (2.33) & 39.4 & (1.80) & 32.9 & (5.74) & 37.5 & (1.61) & 35.0 & (12.03) \\
\hline Ireland & 54.1 & $(1.37)$ & 55.7 & $(1.54)$ & 50.7 & (2.56) & 54.8 & (1.87) & 53.5 & (1.61) & 46.5 & (5.83) & 54.6 & $(1.45)$ & 53.6 & $(2.85)$ & 53.6 & $(2.28)$ & 53.8 & $(1.81)$ \\
\hline Italy & 56.4 & $(0.98)$ & 58.4 & (1.08) & 49.2 & (1.78) & 57.0 & (1.85) & 56.2 & $(1.07)$ & 54.0 & (2.38) & 62.9 & (3.09) & 56.1 & $(1.07)$ & 56.5 & $(1.03)$ & 48.5 & $(5.20)$ \\
\hline Korea & 58.2 & $(1.16)$ & 60.5 & $(1.28)$ & 54.1 & (1.92) & 67.6 & $(1.57)$ & 52.5 & (1.53) & 68.1 & $(13.27)$ & 58.5 & $(1.42)$ & 57.6 & $(1.72)$ & 59.6 & $(1.41)$ & 50.8 & (3.98) \\
\hline Lithuania & 44.7 & $(1.10)$ & 45.4 & $(1.12)$ & 40.9 & $(2.80)$ & 47.9 & (1.79) & 43.3 & $(1.28)$ & 44.0 & (2.18) & 45.2 & $(1.40)$ & 44.2 & $(1.84)$ & 45.0 & $(1.10)$ & 31.6 & (6.43) \\
\hline Malaysia & 82.9 & $(0.95)$ & 83.8 & $(1.10)$ & 81.1 & $(1.30)$ & 86.5 & $(1.12)$ & 77.3 & $(1.28)$ & 75.0 & (2.21) & 83.9 & $(1.05)$ & 85.8 & $(2.12)$ & 83.0 & $(0.97)$ & 66.9 & $(11.42)$ \\
\hline Malta & 43.3 & $(1.79)$ & 44.4 & $(2.33)$ & 41.4 & (3.10) & 42.5 & $(2.22)$ & 44.6 & (3.04) & 40.5 & $(4.26)$ & 43.3 & (1.99) & 48.0 & $(5.52)$ & 41.1 & $(2.44)$ & 47.7 & (2.04) \\
\hline Mexico & 85.3 & $(0.85)$ & 86.3 & (1.04) & 84.1 & (1.15) & 88.0 & (1.04) & 83.3 & $(1.15)$ & 80.8 & (3.10) & 86.1 & $(0.88)$ & 86.6 & $(2.15)$ & 85.7 & $(0.80)$ & 84.8 & (3.28) \\
\hline Norway & 70.3 & $(1.13)$ & 72.5 & $(1.43)$ & 67.1 & $(1.76)$ & 70.3 & $(1.72)$ & 70.4 & $(1.45)$ & 52.6 & $(12.23)$ & 71.1 & $(1.36)$ & 68.6 & $(2.11)$ & 70.6 & $(1.16)$ & 72.9 & $(8.17)$ \\
\hline Poland & 43.6 & $(1.04)$ & 45.1 & $(1.28)$ & 38.9 & $(2.07)$ & 49.5 & $(1.54)$ & 37.3 & $(1.26)$ & 40.7 & $(8.80)$ & 47.5 & (4.38) & 43.3 & $(1.07)$ & 43.5 & $(1.01)$ & 45.2 & $(7.26)$ \\
\hline Portugal & 76.2 & $(0.91)$ & 77.5 & $(1.04)$ & 73.1 & (1.56) & 77.3 & $(1.22)$ & 75.1 & $(1.43)$ & 70.7 & $(4.35)$ & 76.0 & $(0.99)$ & 79.8 & $(2.52)$ & 77.0 & $(0.98)$ & 66.0 & $(3.51)$ \\
\hline Slovak Republic & 43.2 & $(1.34)$ & 44.3 & $(1.37)$ & 38.6 & $(2.98)$ & 48.4 & $(1.90)$ & 39.6 & $(1.78)$ & 38.4 & $(7.68)$ & 47.3 & $(15.00)$ & 43.6 & $(1.40)$ & 42.6 & $(1.35)$ & 46.3 & $(3.89)$ \\
\hline Slovenia & 35.1 & $(1.18)$ & 34.9 & $(1.23)$ & 36.0 & $(2.38)$ & 39.5 & $(1.82)$ & 32.2 & $(1.36)$ & 28.8 & $(1.48)$ & 40.7 & $(1.50)$ & 36.0 & $(7.85)$ & 34.9 & $(1.14)$ & $\mathrm{a}$ & $\mathrm{a}$ \\
\hline Spain & 60.6 & $(1.02)$ & 63.8 & $(1.28)$ & 56.4 & $(1.43)$ & 68.6 & $(1.59)$ & 56.0 & $(1.29)$ & 47.6 & (3.83) & 56.5 & $(2.53)$ & 62.0 & $(1.16)$ & 60.6 & $(1.23)$ & 59.5 & $(2.31)$ \\
\hline Turkey & 48.2 & $(2.21)$ & 51.3 & (2.13) & 44.8 & (3.22) & 51.2 & $(2.40)$ & 37.2 & (3.56) & 26.2 & $(5.62)$ & 48.8 & $(2.23)$ & 58.8 & $(6.69)$ & 48.4 & $(2.51)$ & 41.6 & $(3.71)$ \\
\hline TALIS average & 54.8 & $(0.27)$ & 56.3 & $(0.32)$ & 51.7 & $(0.49)$ & 57.5 & $(0.40)$ & 52.4 & $(0.36)$ & 48.1 & (1.47) & 55.4 & $(0.85)$ & 56.6 & $(0.74)$ & 54.9 & $(0.31)$ & 53.3 & (1.26) \\
\hline
\end{tabular}

Denotes categories that include less than $5 \%$ of teachers.

Source: OECD (2009), Creating Effective Teaching and Learning Environments: First Results from TALIS.

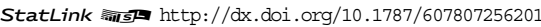




\section{Table A.11}

Teachers' high professional development needs (2007-08)

Percentage of teachers of lower secondary education indicating they have a "High level of need" for professional development in the following areas and overall index of need

\begin{tabular}{|c|c|c|c|c|c|c|c|c|c|c|c|c|}
\hline & \multicolumn{2}{|c|}{$\begin{array}{l}\text { Overall index of } \\
\text { development need } \\
(\text { Maximum }=100)^{1}\end{array}$} & \multicolumn{2}{|c|}{$\begin{array}{l}\text { Content and } \\
\text { performance } \\
\text { standards }\end{array}$} & \multicolumn{2}{|c|}{$\begin{array}{l}\text { Student assessment } \\
\text { practices }\end{array}$} & \multicolumn{2}{|c|}{ Classroom management } & \multicolumn{2}{|c|}{ Subject field } & \multicolumn{2}{|c|}{ Instructional practices } \\
\hline & Index & (S.E.) & $\%$ & (S.E.) & $\%$ & (S.E.) & $\%$ & (S.E.) & $\%$ & (S.E.) & $\%$ & (S.E.) \\
\hline Australia & 44 & $(0.35)$ & 8.3 & $(0.64)$ & 7.5 & $(0.60)$ & 5.2 & $(0.52)$ & 5.0 & $(0.53)$ & 3.6 & $(0.40)$ \\
\hline Austria & 51 & $(0.31)$ & 13.9 & $(0.69)$ & 12.2 & $(0.53)$ & 13.6 & $(0.64)$ & 14.8 & $(0.59)$ & 18.6 & $(0.75)$ \\
\hline Belgium (FI.) & 47 & $(0.39)$ & 12.0 & $(0.65)$ & 15.6 & $(0.74)$ & 12.1 & $(0.59)$ & 17.5 & $(0.74)$ & 14.1 & $(0.77)$ \\
\hline Brazil & 58 & $(0.55)$ & 23.1 & $(1.31)$ & 21.1 & (1.15) & 13.7 & $(0.98)$ & 14.9 & $(1.06)$ & 14.8 & (1.06) \\
\hline Bulgaria & 50 & $(0.59)$ & 25.7 & $(2.33)$ & 16.1 & (1.45) & 12.7 & $(1.46)$ & 21.2 & (1.53) & 18.3 & $(1.67)$ \\
\hline Denmark & 44 & $(0.59)$ & 17.1 & (1.25) & 13.6 & $(0.97)$ & 2.3 & $(0.55)$ & 4.6 & $(0.54)$ & 4.7 & $(0.57)$ \\
\hline Estonia & 55 & $(0.49)$ & 17.7 & (0.95) & 10.4 & $(0.65)$ & 13.4 & $(0.76)$ & 22.6 & (1.01) & 18.2 & $(0.78)$ \\
\hline Hungary & 45 & $(0.51)$ & 9.2 & $(0.55)$ & 5.9 & $(0.51)$ & 3.3 & $(0.36)$ & 7.4 & $(0.64)$ & 14.7 & $(0.81)$ \\
\hline Iceland & 52 & $(0.48)$ & 7.3 & $(0.74)$ & 14.3 & $(1.00)$ & 11.6 & $(0.90)$ & 10.3 & $(0.91)$ & 8.2 & $(0.76)$ \\
\hline Ireland & 49 & $(0.48)$ & 6.7 & $(0.52)$ & 8.2 & $(0.77)$ & 6.4 & $(0.59)$ & 4.1 & $(0.49)$ & 5.4 & $(0.60)$ \\
\hline Italy & 63 & $(0.30)$ & 17.6 & $(0.69)$ & 24.0 & $(0.83)$ & 18.9 & $(0.84)$ & 34.0 & $(0.75)$ & 34.9 & $(0.89)$ \\
\hline Korea & 70 & $(0.30)$ & 26.8 & $(0.92)$ & 21.5 & $(0.79)$ & 30.3 & $(0.91)$ & 38.3 & $(0.96)$ & 39.9 & $(0.91)$ \\
\hline Lithuania & 62 & $(0.41)$ & 39.2 & (1.01) & 37.3 & (1.03) & 27.9 & $(0.96)$ & 43.4 & $(0.89)$ & 44.5 & $(0.90)$ \\
\hline Malaysia & 72 & $(0.64)$ & 49.8 & (1.59) & 43.8 & $(1.43)$ & 41.6 & $(1.41)$ & 56.8 & (1.53) & 55.2 & $(1.47)$ \\
\hline Malta & 48 & $(0.57)$ & 8.1 & $(1.00)$ & 7.2 & $(0.82)$ & 5.3 & $(0.78)$ & 6.7 & $(0.86)$ & 3.9 & $(0.60)$ \\
\hline Mexico & 50 & $(0.59)$ & 13.7 & $(0.77)$ & 15.0 & $(0.83)$ & 8.8 & $(0.66)$ & 11.0 & $(0.88)$ & 12.3 & $(0.92)$ \\
\hline Norway & 55 & $(0.51)$ & 12.9 & $(0.85)$ & 21.9 & (1.29) & 7.7 & $(0.66)$ & 8.6 & $(0.70)$ & 8.2 & $(0.61)$ \\
\hline Poland & 49 & $(0.50)$ & 11.9 & $(0.74)$ & 12.8 & $(0.77)$ & 17.6 & $(0.95)$ & 17.0 & $(0.87)$ & 17.5 & $(0.75)$ \\
\hline Portugal & 56 & $(0.31)$ & 9.8 & $(0.62)$ & 6.9 & $(0.51)$ & 5.8 & $(0.47)$ & 4.8 & $(0.43)$ & 7.7 & $(0.54)$ \\
\hline Slovak Republic & 48 & $(0.56)$ & 8.2 & $(0.66)$ & 9.0 & $(0.57)$ & 9.8 & $(0.81)$ & 17.2 & $(0.96)$ & 13.4 & $(0.89)$ \\
\hline Slovenia & 57 & $(0.35)$ & 13.4 & $(0.67)$ & 22.3 & $(0.89)$ & 24.0 & $(0.79)$ & 15.9 & $(0.78)$ & 19.9 & $(0.80)$ \\
\hline Spain & 49 & $(0.44)$ & 6.0 & $(0.38)$ & 5.8 & $(0.42)$ & 8.1 & $(0.57)$ & 5.0 & $(0.47)$ & 5.5 & $(0.39)$ \\
\hline Turkey & 43 & $(0.72)$ & 9.8 & $(0.81)$ & 9.2 & $(0.90)$ & 6.7 & (1.29) & 8.9 & $(0.93)$ & 9.0 & $(0.92)$ \\
\hline TALIS average & 53 & $(0.10)$ & 16.0 & $(0.20)$ & 15.7 & $(0.19)$ & 13.3 & $(0.18)$ & 17.0 & $(0.18)$ & 17.1 & $(0.18)$ \\
\hline
\end{tabular}

\begin{tabular}{|c|c|c|c|c|c|c|c|c|c|c|c|c|}
\hline & \multicolumn{2}{|c|}{ ICT teaching skills } & \multicolumn{2}{|c|}{$\begin{array}{c}\text { Teaching special } \\
\text { learning needs students }\end{array}$} & \multicolumn{2}{|c|}{$\begin{array}{c}\text { Student discipline and } \\
\text { behaviour problems }\end{array}$} & \multicolumn{2}{|c|}{$\begin{array}{l}\text { School management } \\
\text { and administration }\end{array}$} & \multicolumn{2}{|c|}{$\begin{array}{c}\text { Teaching in a } \\
\text { multicultural setting }\end{array}$} & \multicolumn{2}{|c|}{ Student counselling } \\
\hline & $\%$ & (S.E.) & $\%$ & (S.E.) & $\%$ & (S.E.) & $\%$ & (S.E.) & $\%$ & (S.E.) & $\%$ & (S.E.) \\
\hline Australia & 17.8 & $(0.94)$ & 15.1 & $(0.98)$ & 6.6 & $(0.71)$ & 5.9 & $(0.53)$ & 4.0 & $(0.43)$ & 7.3 & $(0.61)$ \\
\hline Austria & 23.8 & $(0.64)$ & 30.3 & $(0.94)$ & 32.6 & $(1.03)$ & 3.9 & $(0.37)$ & 10.0 & $(0.68)$ & 13.1 & $(0.65)$ \\
\hline Belgium (FI.) & 14.8 & $(0.72)$ & 12.8 & $(0.76)$ & 11.8 & $(0.71)$ & 2.4 & $(0.31)$ & 3.7 & $(0.46)$ & 11.0 & $(0.68)$ \\
\hline Brazil & 35.6 & $(1.33)$ & 63.2 & $(1.21)$ & 26.5 & $(1.12)$ & 20.0 & $(0.78)$ & 33.2 & $(1.22)$ & 20.7 & $(1.14)$ \\
\hline Bulgaria & 26.9 & (1.58) & 24.4 & $(1.47)$ & 14.9 & $(1.82)$ & 8.5 & $(0.95)$ & 15.5 & $(2.35)$ & 10.4 & (1.30) \\
\hline Denmark & 20.1 & (1.67) & 24.6 & $(1.44)$ & 9.8 & $(1.21)$ & 3.9 & $(0.49)$ & 7.1 & $(0.98)$ & 5.5 & $(0.66)$ \\
\hline Estonia & 27.9 & $(0.91)$ & 28.1 & $(0.95)$ & 23.6 & $(1.02)$ & 4.6 & $(0.37)$ & 9.7 & $(0.77)$ & 21.5 & $(0.95)$ \\
\hline Hungary & 23.0 & (1.15) & 42.0 & $(1.57)$ & 31.2 & (1.50) & 3.4 & $(0.96)$ & 10.7 & $(0.68)$ & 8.4 & $(0.83)$ \\
\hline Iceland & 17.3 & (1.08) & 23.2 & (1.16) & 20.0 & $(0.97)$ & 7.9 & $(0.84)$ & 14.0 & $(0.92)$ & 12.9 & $(0.86)$ \\
\hline Ireland & 34.2 & $(1.30)$ & 38.3 & $(1.32)$ & 13.9 & $(0.98)$ & 11.8 & $(0.94)$ & 24.3 & (1.31) & 24.9 & (1.33) \\
\hline Italy & 25.8 & $(0.81)$ & 35.3 & (1.05) & 28.3 & (1.04) & 8.6 & $(0.49)$ & 25.3 & $(0.85)$ & 19.7 & $(0.87)$ \\
\hline Korea & 17.7 & $(0.67)$ & 25.6 & $(0.88)$ & 34.6 & $(0.92)$ & 10.8 & $(0.62)$ & 10.4 & $(0.61)$ & 41.5 & (1.04) \\
\hline Lithuania & 36.1 & $(0.93)$ & 25.4 & $(0.95)$ & 24.3 & $(0.89)$ & 9.8 & $(0.68)$ & 9.8 & $(0.79)$ & 18.6 & (1.09) \\
\hline Malaysia & 43.8 & (1.18) & 25.9 & $(1.08)$ & 41.6 & (1.41) & 29.9 & (1.14) & 30.3 & (1.35) & 35.1 & $(1.21)$ \\
\hline Malta & 22.8 & (1.51) & 34.4 & (1.56) & 10.5 & (1.18) & 12.9 & (1.31) & 14.0 & (1.36) & 15.8 & (1.29) \\
\hline Mexico & 24.9 & (1.09) & 38.8 & $(1.27)$ & 21.4 & (1.04) & 11.9 & $(0.71)$ & 18.2 & $(0.93)$ & 25.9 & (1.12) \\
\hline Norway & 28.1 & (1.19) & 29.2 & (1.04) & 16.5 & $(0.93)$ & 5.8 & $(0.57)$ & 8.3 & $(0.75)$ & 7.8 & $(0.63)$ \\
\hline Poland & 22.2 & $(0.90)$ & 29.4 & $(1.28)$ & 23.5 & $(0.94)$ & 7.8 & $(0.57)$ & 6.6 & $(0.58)$ & 25.4 & (1.01) \\
\hline Portugal & 24.2 & $(0.89)$ & 50.0 & (1.06) & 17.4 & $(0.88)$ & 18.2 & $(0.90)$ & 17.0 & $(0.73)$ & 8.5 & $(0.61)$ \\
\hline Slovak Republic & 14.8 & $(0.97)$ & 20.1 & $(0.97)$ & 19.2 & $(1.26)$ & 4.8 & $(0.46)$ & 4.6 & $(0.52)$ & 7.9 & $(0.58)$ \\
\hline Slovenia & 25.1 & $(0.81)$ & 40.4 & (1.09) & 32.0 & (1.04) & 7.0 & $(0.59)$ & 9.9 & $(0.68)$ & 21.1 & $(0.83)$ \\
\hline Spain & 26.2 & (1.08) & 35.8 & (1.04) & 18.3 & $(0.76)$ & 14.2 & $(0.64)$ & 17.5 & $(0.73)$ & 12.0 & $(0.62)$ \\
\hline Turkey & 14.2 & $(0.85)$ & 27.8 & $(1.70)$ & 13.4 & $(1.44)$ & 9.3 & $(0.78)$ & 14.5 & (1.10) & 9.5 & (1.16) \\
\hline TALIS average & 24.7 & $(0.23)$ & 31.3 & $(0.25)$ & 21.4 & $(0.23)$ & 9.7 & $(0.15)$ & 13.9 & $(0.21)$ & 16.7 & $(0.20)$ \\
\hline
\end{tabular}

1. Index derived from aggregating the development need for each teacher over all of the aspects of their work: 3 points for a high level of need; 2 points for a moderate level of need, 1 point for a low level of need and no points for cases where teachers noted no development need at all. These were then aggregated and divided by the maximum possible score of 33 and multiplied by 100 .

Source: OECD (2009), Creating Effective Teaching and Learning Environments: First Results from TALIS.

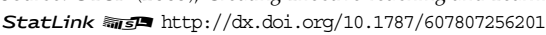


Table A.12

Support for professional development undertaken by teachers (2007-08)

Percentage of those teachers of lower secondary education who undertook professional development and received the following types of support

\begin{tabular}{|c|c|c|c|c|c|c|c|c|c|c|}
\hline & \multicolumn{6}{|c|}{ Teacher contribution to the cost of professional development undertaken } & \multirow{2}{*}{\multicolumn{2}{|c|}{$\begin{array}{l}\text { Teacher received } \\
\text { scheduled time }\end{array}$}} & \multirow{2}{*}{\multicolumn{2}{|c|}{$\begin{array}{l}\text { Teacher received } \\
\text { salary supplement }\end{array}$}} \\
\hline & \multicolumn{2}{|c|}{ Paid none of the costs } & \multicolumn{2}{|c|}{ Paid some of the costs } & \multicolumn{2}{|c|}{ Paid all of the costs } & & & & \\
\hline & $\%$ & (S.E.) & $\%$ & (S.E.) & $\%$ & (S.E.) & $\%$ & (S.E.) & $\%$ & (S.E.) \\
\hline Australia & 74.5 & $(1.24)$ & 24.3 & $(1.24)$ & 1.2 & $(0.26)$ & 85.5 & $(0.86)$ & 5.5 & $(0.57)$ \\
\hline Austria & 43.7 & $(1.00)$ & 49.7 & $(1.01)$ & 6.6 & $(0.45)$ & 89.0 & $(0.72)$ & 11.7 & (0.68) \\
\hline Belgium (FI.) & 81.4 & (1.32) & 15.3 & (1.10) & 3.2 & $(0.46)$ & 78.1 & (1.63) & 2.2 & (0.49) \\
\hline Brazil & 54.8 & (1.59) & 26.9 & (1.36) & 18.3 & $(1.22)$ & 56.2 & (1.67) & 10.9 & (0.88) \\
\hline Bulgaria & 73.4 & (2.06) & 20.5 & (2.16) & 6.1 & $(0.68)$ & 40.4 & (1.88) & 8.1 & $(0.91)$ \\
\hline Denmark & 77.3 & (1.45) & 16.3 & (1.13) & 6.4 & $(0.93)$ & 71.8 & (2.34) & 9.2 & (1.64) \\
\hline Estonia & 72.5 & $(0.98)$ & 25.6 & $(0.93)$ & 2.0 & $(0.28)$ & 64.2 & (1.37) & 12.0 & $(0.88)$ \\
\hline Hungary & 71.5 & (1.99) & 20.5 & $(1.76)$ & 8.0 & $(0.76)$ & 44.4 & (2.95) & 5.9 & (0.85) \\
\hline Iceland & 67.8 & (1.34) & 27.8 & (1.42) & 4.5 & $(0.61)$ & 70.3 & (1.39) & 17.9 & (1.24) \\
\hline Ireland & 79.3 & (1.03) & 17.5 & (0.99) & 3.2 & $(0.46)$ & 94.7 & $(0.53)$ & 5.8 & $(0.67)$ \\
\hline Italy & 68.7 & $(1.04)$ & 13.7 & $(0.65)$ & 17.6 & $(0.78)$ & 30.9 & (1.38) & 9.6 & $(0.74)$ \\
\hline Korea & 27.1 & (1.07) & 58.5 & (1.06) & 14.4 & $(0.79)$ & 24.3 & $(0.94)$ & 19.8 & (1.02) \\
\hline Lithuania & 65.2 & $(1.75)$ & 30.0 & $(1.48)$ & 4.8 & $(0.57)$ & 69.1 & $(1.26)$ & 6.5 & (0.58) \\
\hline Malaysia & 43.5 & $(1.52)$ & 52.7 & (1.54) & 3.9 & $(0.38)$ & 88.6 & $(0.80)$ & 2.5 & $(0.31)$ \\
\hline Malta & 87.1 & (1.29) & 10.6 & (1.18) & 2.2 & $(0.51)$ & 78.2 & (1.62) & 48.7 & (1.94) \\
\hline Mexico & 43.2 & (1.31) & 38.0 & (1.12) & 18.8 & (1.14) & 71.1 & (1.52) & 2.9 & (0.45) \\
\hline Norway & 79.8 & (1.14) & 17.0 & (1.05) & 3.3 & $(0.44)$ & 66.3 & (1.56) & 7.2 & $(0.74)$ \\
\hline Poland & 44.2 & (1.30) & 45.1 & $(1.12)$ & 10.7 & $(0.85)$ & 57.0 & (1.68) & 5.4 & $(0.61)$ \\
\hline Portugal & 50.3 & $(1.43)$ & 25.2 & (1.14) & 24.5 & $(1.24)$ & 25.1 & (1.68) & 2.0 & $(0.33)$ \\
\hline Slovak Republic & 70.4 & $(1.37)$ & 24.1 & (1.21) & 5.5 & $(0.57)$ & 69.2 & (1.47) & 28.3 & $(1.72)$ \\
\hline Slovenia & 85.3 & $(0.91)$ & 13.7 & $(0.87)$ & 1.0 & $(0.22)$ & 79.3 & (1.28) & 29.7 & (1.18) \\
\hline Spain & 54.8 & (1.33) & 29.6 & $(1.00)$ & 15.6 & $(0.87)$ & 29.5 & $(1.48)$ & 3.3 & $(0.41)$ \\
\hline Turkey & 82.9 & $(1.87)$ & 12.1 & (1.90) & 5.0 & $(0.95)$ & 61.2 & $(2.96)$ & 6.9 & (1.19) \\
\hline TALIS average & 65.2 & $(0.29)$ & 26.7 & $(0.27)$ & 8.1 & $(0.15)$ & 62.8 & $(0.34)$ & 11.4 & $(0.20)$ \\
\hline
\end{tabular}

Source: OECD (2009), Creating Effective Teaching and Learning Environments: First Results from TALIS.

StatLink 解 http://dx.doi.org/10.1787/607807256201

\section{Table A.13}

Frequency of mentoring and induction programmes (2007-08)

Percentage of teachers of lower secondary education whose school principal reported the existence of induction processes and mentoring programmes for teachers new to the school

\begin{tabular}{|c|c|c|c|c|c|c|c|c|c|c|c|c|}
\hline & \multicolumn{6}{|c|}{ Existence of formal induction process in school } & \multicolumn{6}{|c|}{ Existence of a mentoring programme or policy in school } \\
\hline & \multicolumn{2}{|c|}{$\begin{array}{c}\text { Yes, for all teachers new } \\
\text { to the school }\end{array}$} & \multicolumn{2}{|c|}{$\begin{array}{l}\text { Yes but only for } \\
\text { those in their first } \\
\text { teaching job }\end{array}$} & \multicolumn{2}{|c|}{$\begin{array}{c}\text { No formal } \\
\text { induction process }\end{array}$} & \multicolumn{2}{|c|}{$\begin{array}{l}\text { Yes, for all teachers } \\
\text { new to the school }\end{array}$} & \multicolumn{2}{|c|}{$\begin{array}{l}\text { Yes but only for } \\
\text { those in their first } \\
\text { teaching job }\end{array}$} & \multicolumn{2}{|c|}{$\begin{array}{c}\text { No formal } \\
\text { mentoring process }\end{array}$} \\
\hline & $\%$ & (S.E.) & $\%$ & (S.E.) & $\%$ & (S.E.) & $\%$ & (S.E.) & $\%$ & (S.E.) & $\%$ & (S.E.) \\
\hline Australia & 93.1 & $(2.41)$ & 5.6 & $(2.21)$ & 1.3 & $(0.96)$ & 70.4 & $(4.59)$ & 23.8 & $(4.27)$ & 5.8 & $(1.84)$ \\
\hline Austria & 32.1 & $(3.15)$ & 23.6 & $(2.61)$ & 44.3 & $(2.99)$ & 23.0 & $(2.73)$ & 23.0 & $(2.64)$ & 54.1 & $(3.24)$ \\
\hline Belgium (FI.) & 94.4 & (1.69) & 3.9 & $(1.21)$ & 1.7 & (1.08) & 90.5 & $(2.08)$ & 8.8 & $(2.02)$ & 0.7 & $(0.49)$ \\
\hline Brazil & 19.8 & (2.38) & 6.5 & $(1.42)$ & 73.7 & $(2.46)$ & 17.7 & $(2.11)$ & 11.7 & $(2.03)$ & 70.7 & (2.91) \\
\hline Bulgaria & 53.2 & (4.94) & 30.7 & (6.13) & 16.2 & (3.85) & 29.6 & (3.95) & 53.5 & $(4.87)$ & 16.9 & (3.51) \\
\hline Denmark & 47.7 & $(5.22)$ & 23.5 & $(4.51)$ & 28.8 & (3.81) & 62.6 & $(4.52)$ & 27.0 & (3.77) & 10.4 & (2.65) \\
\hline Estonia & 23.1 & (3.68) & 59.1 & $(4.19)$ & 17.8 & (3.14) & 25.8 & (3.49) & 64.9 & $(3.81)$ & 9.2 & (1.98) \\
\hline Hungary & 34.8 & (5.06) & 46.4 & (5.26) & 18.8 & (3.46) & 44.8 & (4.50) & 44.2 & (4.68) & 11.0 & (2.40) \\
\hline Iceland & 72.8 & $(0.17)$ & 15.7 & $(0.13)$ & 11.5 & $(0.12)$ & 44.7 & $(0.17)$ & 48.4 & $(0.16)$ & 6.9 & $(0.04)$ \\
\hline Ireland & 83.7 & (3.67) & 7.2 & $(2.68)$ & 9.0 & (2.64) & 63.8 & $(4.21)$ & 10.7 & $(2.44)$ & 25.5 & (4.10) \\
\hline Italy & 36.6 & $(2.87)$ & 34.4 & $(2.91)$ & 29.0 & $(2.81)$ & 26.3 & $(2.70)$ & 61.3 & (2.99) & 12.4 & (2.16) \\
\hline Korea & 33.6 & (3.33) & 49.8 & (3.75) & 16.6 & (3.03) & 26.8 & $(3.76)$ & 44.3 & $(4.37)$ & 29.0 & (4.18) \\
\hline Lithuania & 17.1 & $(2.61)$ & 14.0 & $(2.49)$ & 68.9 & (3.26) & 29.0 & (3.59) & 50.6 & $(4.08)$ & 20.4 & (3.13) \\
\hline Malaysia & 43.0 & (3.62) & 40.9 & $(4.00)$ & 16.2 & (2.87) & 45.0 & (3.71) & 38.1 & (3.82) & 16.9 & (2.61) \\
\hline Malta & 25.3 & $(0.17)$ & 11.8 & $(0.11)$ & 62.9 & $(0.18)$ & 22.4 & $(0.18)$ & 12.3 & $(0.12)$ & 65.3 & $(0.20)$ \\
\hline Mexico & 22.7 & (3.35) & 14.7 & $(2.91)$ & 62.6 & (3.94) & 19.2 & $(3.47)$ & 20.4 & $(3.52)$ & 60.5 & (4.14) \\
\hline Norway & 29.9 & (3.83) & 18.3 & (3.25) & 51.8 & $(4.27)$ & 43.3 & (3.85) & 25.4 & (3.67) & 31.3 & (3.67) \\
\hline Poland & 14.3 & (3.13) & 79.4 & (3.63) & 6.3 & (2.15) & 23.5 & (3.97) & 71.9 & $(4.32)$ & 4.6 & $(1.87)$ \\
\hline Portugal & 73.1 & (3.52) & 4.2 & (1.69) & 22.7 & (3.20) & 41.3 & (4.48) & 20.4 & (3.53) & 38.3 & $(4.32)$ \\
\hline Slovak Republic & 62.1 & (3.85) & 35.5 & $(3.67)$ & 2.4 & (1.53) & 26.4 & $(4.06)$ & 71.3 & $(4.22)$ & 2.4 & $(1.32)$ \\
\hline Slovenia & 41.1 & (3.83) & 51.5 & $(4.06)$ & 7.4 & (2.01) & 23.5 & (3.55) & 64.6 & $(4.02)$ & 11.9 & (2.65) \\
\hline Spain & 20.9 & $(3.22)$ & 15.7 & $(2.71)$ & 63.4 & (3.70) & 17.6 & $(2.77)$ & 18.1 & (2.74) & 64.3 & $(3.60)$ \\
\hline Turkey & 50.2 & $(5.27)$ & 16.2 & $(4.04)$ & 33.6 & (5.10) & 22.3 & (4.85) & 69.6 & (5.51) & 8.1 & $(3.22)$ \\
\hline TALIS average & 44.5 & $(0.73)$ & 26.5 & $(0.70)$ & 29.0 & $(0.62)$ & 36.5 & $(0.75)$ & 38.4 & $(0.76)$ & 25.1 & $(0.60)$ \\
\hline
\end{tabular}

Source: OECD (2009), Creating Effective Teaching and Learning Environments: First Results from TALIS.

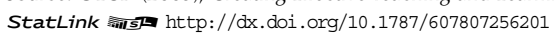




\section{Table A.14}

\section{Reasons for not participating in more professional development (2007-08)}

Percentage of teachers of lower secondary education who wanted more professional development and gave the following reasons for not undertaking more

\begin{tabular}{|c|c|c|c|c|c|c|c|c|c|c|c|c|}
\hline & \multicolumn{12}{|c|}{ Reason for not undertaking more professional development } \\
\hline & \multicolumn{2}{|c|}{$\begin{array}{l}\text { Did not have } \\
\text { the pre-requisites }\end{array}$} & \multicolumn{2}{|c|}{ Too expensive } & \multicolumn{2}{|c|}{$\begin{array}{c}\text { Lack of } \\
\text { employer support }\end{array}$} & \multicolumn{2}{|c|}{$\begin{array}{l}\text { Conflict with } \\
\text { work schedule }\end{array}$} & \multicolumn{2}{|c|}{$\begin{array}{c}\text { Family } \\
\text { responsibilities }\end{array}$} & \multicolumn{2}{|c|}{$\begin{array}{l}\text { No suitable } \\
\text { professional } \\
\text { development }\end{array}$} \\
\hline & $\%$ & (S.E.) & $\%$ & (S.E.) & $\%$ & (S.E.) & $\%$ & (S.E.) & $\%$ & (S.E.) & $\%$ & (S.E.) \\
\hline Australia & 3.2 & $(0.59)$ & 32.6 & $(1.61)$ & 26.5 & $(1.52)$ & 61.7 & $(1.93)$ & 27.6 & $(1.73)$ & 40.5 & $(1.80)$ \\
\hline Austria & 2.6 & $(0.46)$ & 18.0 & $(0.93)$ & 9.3 & $(0.79)$ & 41.5 & (1.34) & 29.0 & (1.21) & 64.2 & (1.15) \\
\hline Belgium (FI.) & 3.6 & $(0.86)$ & 11.8 & (1.33) & 10.9 & $(1.40)$ & 43.2 & (1.69) & 40.6 & $(1.70)$ & 38.8 & (1.73) \\
\hline Brazil & 5.1 & $(0.46)$ & 51.0 & $(1.46)$ & 24.6 & (1.35) & 57.8 & (1.46) & 18.4 & $(0.92)$ & 27.0 & (1.22) \\
\hline Bulgaria & 7.0 & (1.61) & 34.6 & (2.41) & 2.9 & $(0.47)$ & 24.4 & (1.46) & 16.6 & (1.22) & 48.3 & (2.35) \\
\hline Denmark & 1.8 & $(0.44)$ & 29.6 & (1.94) & 38.3 & $(1.76)$ & 23.7 & (1.90) & 15.4 & $(1.21)$ & 42.1 & (1.99) \\
\hline Estonia & 4.2 & $(0.62)$ & 35.1 & (1.59) & 15.3 & (1.30) & 60.5 & (1.65) & 25.2 & (1.35) & 52.3 & (1.61) \\
\hline Hungary & 5.6 & $(0.85)$ & 46.9 & (2.40) & 23.0 & (1.90) & 40.3 & (1.88) & 24.5 & (1.77) & 25.9 & (1.89) \\
\hline Iceland & 1.8 & $(0.70)$ & 18.6 & (1.61) & 6.7 & (1.18) & 43.0 & (2.41) & 35.4 & (1.99) & 47.0 & (2.36) \\
\hline Ireland & 5.5 & $(0.75)$ & 12.2 & $(0.96)$ & 13.9 & $(1.47)$ & 42.6 & (1.53) & 29.4 & (1.57) & 45.2 & (1.83) \\
\hline Italy & 5.1 & $(0.44)$ & 23.5 & (1.23) & 5.8 & $(0.50)$ & 43.1 & $(1.47)$ & 40.8 & (1.38) & 47.2 & (1.37) \\
\hline Korea & 11.9 & $(0.95)$ & 19.9 & $(0.98)$ & 8.7 & (0.93) & 73.3 & (1.26) & 32.7 & (1.30) & 42.2 & (1.28) \\
\hline Lithuania & 7.7 & $(0.90)$ & 25.7 & (1.45) & 15.9 & (1.19) & 46.7 & (1.63) & 26.4 & $(1.20)$ & 53.2 & (1.60) \\
\hline Malaysia & 28.4 & (1.38) & 22.2 & (1.41) & 13.7 & (1.14) & 58.9 & (1.30) & 31.3 & (1.32) & 45.9 & (1.25) \\
\hline Malta & 4.7 & $(1.06)$ & 18.4 & (2.06) & 10.2 & (1.73) & 38.8 & $(2.37)$ & 45.4 & (2.85) & 40.5 & (2.84) \\
\hline Mexico & 17.2 & $(1.07)$ & 49.0 & (1.44) & 21.1 & (1.01) & 48.7 & (1.31) & 37.4 & (1.29) & 20.3 & $(0.97)$ \\
\hline Norway & 2.5 & $(0.38)$ & 31.6 & (1.36) & 26.4 & (1.79) & 50.4 & (1.44) & 26.5 & (1.37) & 30.0 & (1.36) \\
\hline Poland & 3.4 & $(0.51)$ & 51.2 & $(1.72)$ & 12.3 & $(1.20)$ & 40.7 & $(1.90)$ & 32.6 & $(1.63)$ & 38.7 & (1.84) \\
\hline Portugal & 6.5 & $(0.63)$ & 36.3 & (1.14) & 10.4 & $(0.66)$ & 65.5 & (1.26) & 35.6 & (1.28) & 48.2 & (1.23) \\
\hline Slovak Republic & 9.5 & $(0.96)$ & 18.8 & (1.48) & 12.8 & (1.32) & 38.2 & (1.95) & 20.6 & (1.35) & 58.0 & (1.81) \\
\hline Slovenia & 3.7 & $(0.74)$ & 35.9 & (1.57) & 18.2 & (1.48) & 47.8 & (1.75) & 22.3 & (1.25) & 32.6 & (1.52) \\
\hline Spain & 6.7 & $(0.67)$ & 19.2 & (0.99) & 6.3 & $(0.66)$ & 50.3 & (1.23) & 48.4 & (1.43) & 38.4 & (1.25) \\
\hline Turkey & 16.9 & (2.03) & 12.4 & $(1.48)$ & 11.9 & (1.51) & 34.7 & $(3.47)$ & 31.2 & (2.68) & 46.6 & (2.22) \\
\hline TALIS average & 7.2 & $(0.19)$ & 28.5 & $(0.32)$ & 15.0 & $(0.27)$ & 46.8 & $(0.37)$ & 30.1 & $(0.33)$ & 42.3 & $(0.36)$ \\
\hline
\end{tabular}

Source: OECD (2009), Creating Effective Teaching and Learning Environments: First Results from TALIS.

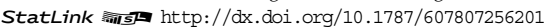

\section{Table A.15}

Impact of different types of professional development undertaken by teachers (2007-08)

Percentage of teachers of lower secondary education reporting that the professional development undertaken in the previous 18 months had a moderate or high impact upon their development as teachers

\begin{tabular}{|c|c|c|c|c|c|c|c|c|c|c|c|c|c|c|c|c|c|c|}
\hline & \multicolumn{2}{|c|}{$\begin{array}{l}\text { Courses and } \\
\text { workshops }\end{array}$} & \multicolumn{2}{|c|}{$\begin{array}{c}\text { Education } \\
\text { conferences } \\
\text { and seminars }\end{array}$} & \multicolumn{2}{|c|}{$\begin{array}{l}\text { Qualification } \\
\text { programmes }\end{array}$} & \multicolumn{2}{|c|}{$\begin{array}{l}\text { Observation } \\
\text { visits to other } \\
\text { schools }\end{array}$} & \multicolumn{2}{|c|}{$\begin{array}{c}\text { Professional } \\
\text { development } \\
\text { network }\end{array}$} & \multicolumn{2}{|c|}{$\begin{array}{l}\text { Individual and } \\
\text { collaborative } \\
\text { research }\end{array}$} & \multicolumn{2}{|c|}{$\begin{array}{l}\text { Mentoring } \\
\text { and peer } \\
\text { observation }\end{array}$} & \multicolumn{2}{|c|}{$\begin{array}{l}\text { Reading } \\
\text { professional } \\
\text { literature }\end{array}$} & \multicolumn{2}{|c|}{$\begin{array}{l}\text { Informal } \\
\text { dialogue } \\
\text { to improve } \\
\text { teaching }\end{array}$} \\
\hline & $\%$ & (S.E.) & $\%$ & (S.E.) & $\%$ & (S.E.) & $\%$ & (S.E.) & $\%$ & (S.E.) & $\%$ & (S.E.) & $\%$ & (S.E.) & $\%$ & (S.E.) & $\%$ & (S.E.) \\
\hline Australia & 78.5 & (1.04) & 67.6 & $(1.32)$ & 78.6 & $(2.67)$ & 72.2 & $(2.26)$ & 73.5 & $(1.27)$ & 85.8 & $(1.53)$ & 72.5 & $(1.40)$ & 66.4 & $(1.28)$ & 86.0 & $(0.85)$ \\
\hline Austria & 75.7 & $(0.89)$ & 55.5 & (1.24) & 89.0 & (1.21) & 61.0 & (2.99) & 68.6 & (1.33) & 88.4 & $(0.96)$ & 72.7 & (1.63) & 82.4 & $(0.69)$ & 84.9 & $(0.71)$ \\
\hline Belgium (FI.) & 52.9 & (1.26) & 42.6 & (1.82) & 67.0 & (2.01) & 47.0 & (2.84) & 53.9 & (1.92) & 67.6 & (1.52) & 48.1 & (2.64) & 57.8 & (1.20) & 71.7 & (1.05) \\
\hline Brazil & 76.1 & (1.07) & 72.9 & (1.32) & 89.9 & (0.93) & 67.5 & (1.49) & 73.4 & (1.91) & 80.9 & (1.26) & 65.8 & (1.66) & 82.6 & (1.09) & 76.5 & (0.99) \\
\hline Bulgaria & 84.2 & (1.58) & 80.6 & (1.67) & 88.0 & (2.06) & 79.3 & $(3.00)$ & 86.2 & (1.83) & 87.1 & $(1.70)$ & 86.0 & (1.68) & 92.3 & $(1.21)$ & 86.3 & (1.20) \\
\hline Denmark & 86.0 & $(0.96)$ & 82.9 & $(1.70)$ & 96.8 & (1.18) & 83.6 & (3.34) & 88.1 & (1.32) & 94.6 & $(0.86)$ & 78.7 & (3.45) & 84.9 & (1.14) & 92.8 & $(0.89)$ \\
\hline Estonia & 86.4 & $(0.74)$ & 70.4 & (1.52) & 90.4 & (0.99) & 69.9 & (1.27) & 84.3 & (1.06) & 90.5 & (1.04) & 76.8 & (1.58) & 87.3 & $(0.70)$ & 81.8 & (0.94) \\
\hline Hungary & 86.0 & (1.04) & 78.2 & (1.46) & 93.1 & (0.93) & 81.4 & (1.74) & 84.8 & (1.11) & 93.8 & (1.30) & 91.1 & (1.00) & 92.6 & $(0.78)$ & 92.9 & (0.89) \\
\hline Iceland & 83.0 & (1.13) & 73.7 & (1.75) & 92.4 & (1.76) & 80.5 & (1.37) & 90.6 & $(0.85)$ & 94.2 & $(1.70)$ & 77.8 & (2.09) & 88.7 & $(0.97)$ & 91.8 & (0.85) \\
\hline Ireland & 81.9 & (0.96) & 74.5 & (1.55) & 92.5 & (1.53) & 81.0 & (4.35) & 78.7 & (1.36) & 86.8 & (1.41) & 71.3 & (2.81) & 71.0 & (1.55) & 83.0 & (1.00) \\
\hline Italy & 81.9 & (1.17) & 78.5 & (1.16) & 86.8 & (1.58) & 82.6 & (2.06) & 86.6 & (1.06) & 95.1 & $(0.45)$ & 89.6 & (1.03) & 90.9 & $(0.60)$ & 90.6 & $(0.47)$ \\
\hline Korea & 79.2 & $(0.87)$ & 75.1 & (1.36) & 84.2 & (1.37) & 65.2 & (1.15) & 85.4 & (1.01) & 89.9 & $(0.82)$ & 69.5 & (1.17) & 77.4 & $(1.22)$ & 85.8 & $(0.67)$ \\
\hline Lithuania & 91.4 & $(0.62)$ & 83.2 & (1.03) & 88.2 & (1.26) & 90.7 & $(0.81)$ & 90.0 & $(0.94)$ & 91.4 & $(0.78)$ & 85.2 & (1.24) & 96.2 & $(0.41)$ & 92.0 & $(0.64)$ \\
\hline Malaysia & 94.4 & $(0.48)$ & 89.1 & (1.05) & 95.0 & $(0.88)$ & 87.6 & (1.30) & 90.3 & $(0.97)$ & 88.8 & (1.17) & 89.9 & $(0.89)$ & 86.4 & $(0.78)$ & 92.2 & $(0.49)$ \\
\hline Malta & 73.9 & (1.65) & 70.0 & (2.47) & 94.4 & (1.56) & 69.8 & (3.87) & 75.2 & (2.45) & 89.8 & (1.57) & 67.8 & (3.78) & 78.1 & (1.83) & 84.3 & (1.29) \\
\hline Mexico & 85.4 & $(0.77)$ & 82.2 & (1.54) & 91.3 & (1.03) & 77.7 & (1.65) & 81.3 & (1.69) & 91.0 & (0.69) & 78.3 & (1.59) & 84.0 & $(0.98)$ & 81.6 & $(0.92)$ \\
\hline Norway & 79.3 & $(0.96)$ & 73.7 & (1.46) & 93.7 & (1.24) & 71.9 & (2.39) & 81.1 & (1.83) & 95.3 & (1.39) & 77.9 & $(2.62)$ & 78.1 & $(0.93)$ & 95.7 & $(0.44)$ \\
\hline Poland & 86.3 & $(0.73)$ & 75.8 & (1.31) & 92.1 & $(0.97)$ & 78.2 & (2.29) & 88.3 & $(0.91)$ & 92.8 & $(0.90)$ & 77.9 & (1.11) & 93.4 & $(0.49)$ & 90.0 & $(0.70)$ \\
\hline Portugal & 82.8 & $(0.88)$ & 73.0 & (1.38) & 87.0 & (1.12) & 67.4 & $(1.82)$ & 80.7 & (2.04) & 94.0 & $(0.76)$ & 87.6 & $(1.84)$ & 78.9 & (1.04) & 88.1 & $(0.68)$ \\
\hline Slovak Republic & 75.5 & (1.57) & 75.9 & $(1.44)$ & 83.0 & (1.43) & 66.0 & $(2.02)$ & 78.0 & (1.93) & 83.8 & $(3.72)$ & 78.6 & (1.10) & 88.8 & (1.03) & 85.9 & $(0.85)$ \\
\hline Slovenia & 83.3 & $(0.73)$ & 78.6 & $(0.91)$ & 80.2 & (2.43) & 77.3 & (2.74) & 64.1 & (1.30) & 89.9 & (1.44) & 76.1 & (1.53) & 81.5 & $(0.85)$ & 87.0 & $(0.74)$ \\
\hline Spain & 76.5 & $(0.94)$ & 71.8 & (1.75) & 73.1 & (1.97) & 76.2 & (2.31) & 81.5 & (1.49) & 89.9 & $(0.89)$ & 81.1 & (1.49) & 74.4 & (1.01) & 80.2 & $(0.74)$ \\
\hline Turkey & 72.9 & (1.78) & 74.1 & (1.65) & 79.3 & (3.77) & 87.8 & (1.99) & 80.5 & (1.43) & 92.3 & (2.11) & 84.8 & (1.77) & 91.3 & (1.17) & 92.8 & (1.01) \\
\hline TALIS average & 80.6 & $(0.23)$ & 73.9 & $(0.31)$ & 87.2 & $(0.35)$ & 74.9 & $(0.50)$ & 80.2 & $(0.31)$ & 89.3 & $(0.30)$ & 77.6 & $(0.41)$ & 82.8 & $(0.22)$ & 86.7 & $(0.18)$ \\
\hline
\end{tabular}

Source: OECD (2009), Creating Effective Teaching and Learning Environments: First Results from TALIS.

StatLink ailst http://dx.doi.org/10.1787/607807256201 


\section{ORGANISATION FOR ECONOMIC CO-OPERATION AND DEVELOPMENT}

The OECD is a unique forum where governments work together to address the economic, social and environmental challenges of globalisation. The OECD is also at the forefront of efforts to understand and to help governments respond to new developments and concerns, such as corporate governance, the information economy and the challenges of an ageing population. The Organisation provides a setting where governments can compare policy experiences, seek answers to common problems, identify good practice and work to co-ordinate domestic and international policies.

The OECD member countries are: Australia, Austria, Belgium, Canada, Chile, the Czech Republic, Denmark, Estonia, Finland, France, Germany, Greece, Hungary, Iceland, Ireland, Israel, Italy, Japan, Korea, Luxembourg, Mexico, the Netherlands, New Zealand, Norway, Poland, Portugal, the Slovak Republic, Slovenia, Spain, Sweden, Switzerland, Turkey, the United Kingdom and the United States. The European Commission takes part in the work of the OECD.

OECD Publishing disseminates widely the results of the Organisation's statistics gathering and research on economic, social and environmental issues, as well as the conventions, guidelines and standards agreed by its members. 


\section{Building a High-Quality Teaching Profession LESSONS FROM AROUND THE WORLD}

This report presents the best current evidence about what can make teacher-oriented reforms effective. It points to examples of reforms that have produced specific results, show promise or illustrate imaginative ways of implementing change.

A striking contrast between the teaching profession in different countries is its status and the caliber of its recruits. Successful countries have shown how a teaching profession that assumes a high level of responsibility and is well rewarded can attract some of the best graduates into a teaching career.

This publication summarizes the evidence that underpinned the first International Summit on the Teaching Profession held in New York in March 2011 and reflects on the lessons that have been learned. The promising avenues it explores not only include measures at recruitment stage, they also involve transforming the teaching profession from within.

\section{Contents}

Chapter 1. Recruitment and initial preparation of teachers

Chapter 2. Teacher development, support, employment conditions and careers

Chapter 3. Teacher evaluation and compensation

Chapter 4. Teacher engagement in education reform

Please cite this publication as:

OECD (2011), Building a High-Quality Teaching Profession: Lessons from Around the World, OECD Publishing. http://dx.doi.org/10.1787/9789264113046-en

This work is published on the OECD iLibrary, which gathers all OECD books, periodicals and statistical databases. Visit www.oecd-ilibrary.org and do not hesitate to contact us for more information.

\section{1}

